\title{
Organizational change, management capital \& business success : an empirical investigation of firm performance in the Dutch advertising industry, 1984- 1994
}

Citation for published version (APA):

Bosman, C. M. (1997). Organizational change, management capital \& business success : an empirical investigation of firm performance in the Dutch advertising industry, 1984-1994. [Doctoral Thesis, Maastricht University]. Universiteit Maastricht. https://doi.org/10.26481/dis.19971003cb

Document status and date:

Published: 01/01/1997

DOI:

$10.26481 /$ dis. $19971003 \mathrm{cb}$

Document Version:

Publisher's PDF, also known as Version of record

Please check the document version of this publication:

- A submitted manuscript is the version of the article upon submission and before peer-review. There can be important differences between the submitted version and the official published version of record. People interested in the research are advised to contact the author for the final version of the publication, or visit the DOI to the publisher's website.

- The final author version and the galley proof are versions of the publication after peer review.

- The final published version features the final layout of the paper including the volume, issue and page numbers.

Link to publication

\footnotetext{
General rights rights.

- You may freely distribute the URL identifying the publication in the public portal. please follow below link for the End User Agreement:

www.umlib.nl/taverne-license

Take down policy

If you believe that this document breaches copyright please contact us at:

repository@maastrichtuniversity.nl

providing details and we will investigate your claim.
}

Copyright and moral rights for the publications made accessible in the public portal are retained by the authors and/or other copyright owners and it is a condition of accessing publications that users recognise and abide by the legal requirements associated with these

- Users may download and print one copy of any publication from the public portal for the purpose of private study or research.

- You may not further distribute the material or use it for any profit-making activity or commercial gain

If the publication is distributed under the terms of Article 25fa of the Dutch Copyright Act, indicated by the "Taverne" license above, 


\section{ORGANIZATIONAL CHANGE, MANAGEMENT CAPITAL $\&$ BUSINESS SUCCESS}

An empirical investigation of firm performance in the Dutch advertising industry, $1984-1994$ 
"Een schrijver moet je niet beoordelen naar één mislukt hoofdstuk, één mislukt boek.... niet naar éen triviale dichtregel of één slecht vers, maar naar zijn hoogtepunten: want daartoe heeft hij bewezen in staat te zijn geweest..."

Gerard Reve

Moeder en Zoon (p.249) 


\section{ORGANIZATIONAL CHANGE, MANAGEMENT CAPITAL $d$ \\ BUSLNESS SUCCESS}

An empirical investigation of firm performance in the Dutch advertising industry, $1984-1994$

\section{PROEFSCHRIFT}

Ter verkrijging van de graad van doctor aan de Universiteit Maastricht, op gezag van de Rector Magnificus, Prof. Mr. M.J. Cohen, volgens het besluit van het College van Decanen, in het openbaar te verdedigen op vrijdag 3 oktober 1997 om 12.00 uur.

door

Ciska Marjoleine Bosman 
Promotor:

Beoordelingscommissie:
Prof. dr. A. wan Witteloostuign

Prof. dr. S.J. Majjoor (voorzitter)

Prof. dr. P.S.H. Leeflang (Rijksuniversiteit Groningen)

Prof. dr. H. Schreuder

Druk: Drukkerij Elinkwijk b.v. Utrecht 


\section{Dankwoord}

Dit proefschrift zou niet tot stand zijn gekomen zonder de hulp van velen. Een aantal van hen will ik hier specifiek bedanken. Een ieder die ik niet bij naam noem maar die toch, op de een of andere manier, waardevol is geweest bij het tot stand komen wan dit proefschrift, dank ik bij deze voor hun bijdrage.

In eerste instantie gaat mijn dank natuurlijk uit naar mijn promotor, Arjen wan Witteloostuijn, die steeds weer met grote precisie mijn stukken doornam en van goed en gedetailleerd commentaar voorzag en mij door zijn optimisme altijd wist te motiveren. Christophe Boone wil ik bedanken voor zijn waardevolle methodologische en theoretische suggesties. Mijn "roommate" Woody van Olffen verdient speciale dank voor zijn goede gezelschap de laatste jaren en de wijze waarop hij zijn kennis en inzicht inzette bij mijn veelzijdige vragen. Mariellle Heijltjes wil ik apart bedanken woor haar belangrijke adviezen en motiverende steun die ik zowel binnen als buiten de universiteitsmuren heb ontvangen. Vervolgens wil ik Gerard Pfann bedanken voor zijn steun bij de verwerking van de data. Ook bedank ik Gerard Pfann en Daniel Hamermesh voor hun initiatief gezamelijk een onderzoek uit te voeren naar schoonheid en bedrijfsresultaten. Voor de hulp bij het verzamelen en het inbrengen van de data wil ik in het bijzonder Matthieu Beunders, Piety van de Nagel, Heleen Bos, Ozzi Atas, Anneke Brink van Scan, Han Nieman van de Vea en Joke Tessel van de Rota bedanken. Natuurlijk ben ik ook dank werschuldigd aan Steven Maijoor, Peter Leeflang en Hein Schreuder voor het evalueren van dit proefschrift en de suggesties voor verbetering.

Veel dank gaat uit naar mijn ouders, op wiens engelengeduld en veelzijdige hulp ik altijd kon rekenen, zowel in Maastricht als in Nice. En tenslotte bedank ik Eric, omdat hij mijn belangrijkste motivatie- en afleidingsbron was, en ik zonder zijn liefdlevolle steun en toeverlaat dit boek niet had kunnen schrijven. Aan hen drieën draag ik dit boek op.

Ciska Bosman

Maastricht, juli 1997. 


\section{CONTENTS}

Chapter 1: Introduction

Chapter 2: The research sample 5

2.1 Introduction 5

2.2 Choice of the industry 5

2.3 Different studies, different samples 5

2.4 Outlines of the research sample 6

2.5 Data collection 9

2.6 Description of the sample 10

2.6.1 The size of the research sample 10

$\begin{array}{ll}2.6 .2 \text { Concentration } & 13\end{array}$

2.6.3 The top ten of advertising agencies $\quad 16$

$\begin{array}{ll}2.6 .4 \text { Entry and exit } & 19\end{array}$

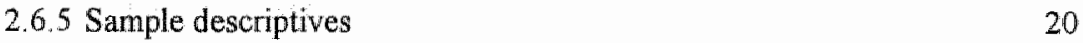

2.7 The financial performance of advertising agencies 24

Chapter 3: Entry, exit and performance 26

3.1 Introduction 26

3.2 Theory, prior research and hypotheses 28

$\begin{array}{ll}3.2 .1 \text { Post-entry performance } & 29\end{array}$

3.2.2 Pre-exit performance 43

3.3 Methods 46

3.3.1 Sample and measurement 46

3.3.2 Analyses $\quad 46$

3.4 Annual entry and exit statistics $\quad 50$

3.4.1 Market shares and average size 53

3.5 Post-entry performance in the Dutch advertising industry 56

3.5.1 Age and exit rates $\quad 57$

3.5.2 Age and market shares $\quad 59$

3.5.3 Age and average size $\quad 60$

3.5.4 Age and firm growth 62

3.5.5 Age and productivity 64

3.5.6 Size, growth and productivity 66

3.6 Pre-exit performance in the Dutch advertising industry 66

3.6.1 A comparison of the performance of surviving and failing agencies 66 
3.6.2 A matched-pair analysis $\quad 70$

3.7 Discussion $\quad 74$

$\begin{array}{lll}3.8 \text { Conclusions } & 78\end{array}$

Chapter 4: Organizational change and business success 79

4.1 Introduction 79

4.2 Theory on organizational change and firm failure $\quad 80$

4.3 Prior research findings $\quad 82$

4.3.1 Summary of research findings $\quad 82$

4.3.2 Evaluation of theory and research findings, and purpose of the study 86

4.4 The advertising industry and the hypotheses . 88

4.5 Methods $\quad 92$

4.5.1 The sample 92

4.5 .2 Variables and measurement 92

4.5.3 Analyses $\quad 95$

4.6 Results 96

4.6.1 Sample descriptives 96

4.6.2 Organizational change and agency performance 101

$\begin{array}{lll}4.7 & \text { Discussion } & 107\end{array}$

4.8 Conclusions 111

Chapter 5: Top managers' demographics and business success $\quad 112$

$\begin{array}{ll}5.1 & \text { Introduction } \\ 5.2 & 112\end{array}$

5.2 Theory and purpose of the study 113

5.3 Top managers" demographics and organizational outcomes 116

$\begin{array}{ll}5.4 & \text { From individual to team effects } \\ 5.5 & 119\end{array}$

$\begin{array}{ll}5.5 \text { Pró research results } & 120\end{array}$

$\begin{array}{ll}5.5 .1 \text { Summary of research findings } & 120\end{array}$

$\begin{array}{ll}\text { 5.5.2 Evaluation of research findings } & 126\end{array}$

5.6 Top managers' demographics in the Dutch advertising industry 128

5.7 Hypotheses on top executives' demographics and firm performance $\quad 130$

$\begin{array}{ll}5.7 .1 \text { Team variables } & 130\end{array}$

$\begin{array}{lr}5.7 .2 \text { Control variables } & 133\end{array}$

5.8 Methods 134

5.8.1 Sample and measurement $\quad 134$

$\begin{array}{ll}5.8 .2 \text { Analyses } & 136\end{array}$

$\begin{array}{lll}5.9 & \text { Results } & 138\end{array}$

$\begin{array}{ll}\text { 5.9.1 Sample descriptives } & 138\end{array}$ 
5.9.2 Average and "proportional" team characteristics and agency performance

5.9.3 Team heterogeneity, interaction effects and agency performance $\quad 145$

5.10 Discussion

5.11 Conclusions

Chapter 6: Summary of conclusions

6.1 Introduction 154

6.2 Summary of empirical results 154

6.2.1 The industry structure and dynamics 154

6.2.2 The direct impact of organizational structure on agency performance 156

6.2.3 The direct effect of strategy on advertising agency performance $\quad 157$

6.2.4 The direct effect of leadership on advertising agency performance 160

6.2.5 The mediating effect of organizational structure on performance $\quad 162$

6.2.6 Indirect effects on performance 163

6.3 The relationship between and reliability of the three performance measures 164

6.4 General conclusions 165

$\begin{array}{ll}6.5 & \text { Contribution to the literature } \\ 6.67\end{array}$

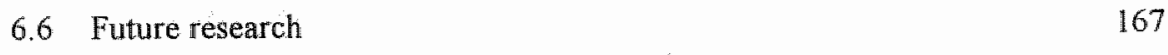

$\begin{array}{ll}\text { Appendix } & \text { Matched pairs of advertising agencies } \\ \end{array}$

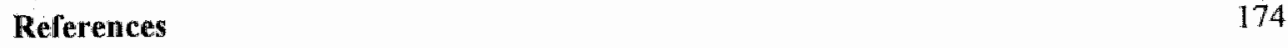

$\begin{array}{ll}\text { Summary in Dutch } & 181\end{array}$

$\begin{array}{ll}\text { Curriculum vitae } & 184\end{array}$ 


\section{CHAPTER 1}

\section{INTRODUCTION}

Why do some organizations succeed while others fail? This is a central question in organization studies, and the subject of the present thesis. In organization sciences, a wide range of factors, both external and internal to the organization, are studied in relation to individual firm performance. The purpose of this thesis is to examine an integrated set of factors explaining variations in company success, addressing three levels of analysis: the industry, the organization and the top management team. Since previous research has indicated that the (importance of) factors influencing business performance are contingent upon the industry, this thesis pertains to a single market: the Dutch industry of advertising agencies. The study is conducted over a period of eleven years, $1984-1994$.

Figure 1.1 presents a framework that highlights the issues under study. The absence of a possible arrow simply indicates that the relationship is not addressed in the thesis, not that the connection does not exist. The most aggregated level of analysis, the industry level, is dealt with in a descriptive manner, i.e., by a depiction of structure aspects and market dynamics (subject $I$ in Figure 1.1). The two lower levels are addressed by examining the impact of organization and top management team features on organizational performance (effects 2 and 3). More specifically, these effects are analyzed by means of three studies:

1. The post-entry and pre-exit performance of advertising agencies.

2. The effect of organizational change on advertising agency performance.

3. The effect of top managers' age, firm tenure, experience and partnership on advertising agency performance.

In study 2 the analyses are carried out separately for small and large advertising firms, so examining the mediating effect of structure on firm performance (effect 5). Indirect structure effects $(7$ and 8$)$ are sideways addressed in these studies as well. Furthermore, each study involves both financial performance measures and the probability of failure. The book is structured along the lines of the three studies, so descending the three levels of analysis.

Chapter 2 describes the outlines of the research sample and the data collection methods Chapter 2 deals, furthermore, with the industry structure and the first part of Chapter 3 pertains to market dynamics, so referring to subject 1 in Figure 1.1. In order to obtain an owerview of the advertising industry as a whole and to understand the context in which the firms under study compete, the industry is investigated, during the eleven-year time period, in terms of the level of concentration, the stability of the top-ten firms (Chapter 2), the rates of 


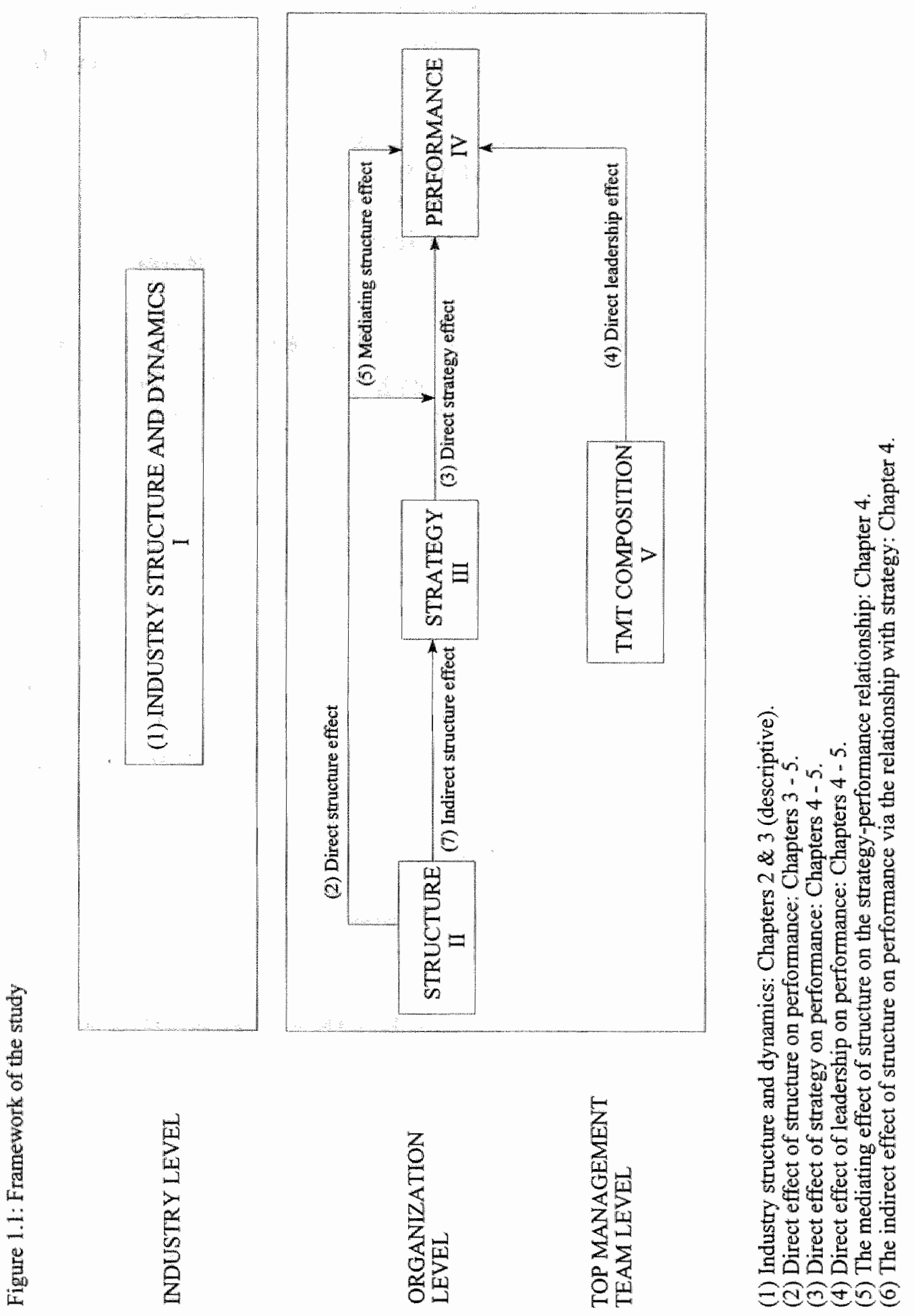


entry and exit, and the relative size and market shares of entrants and exiters (Chapter 3 ).

The second part of Chapter 3 explores the performance and characteristics of new firms in the years subsequent to entry as well as the performance and features of failing firms in the years preceding exit. A comparison is made with the achievements and features of incumbent and surviving agencies, respectively. Chapter 3 concerns, by these means, the direct impact of organization structure on advertising agency performance, 1.e, effect 2 in Figure 1.1. It is the first study to examine the post-entry and pre-exit performance of firms in conjunction and distinguishing between various exit modes in the latter analysis. The chapter is embedded in the field of economics traditionally known as industrial organization. Industrial organization is the economic theory of market functioning and organizational behavior, i.e, the external functioning of organizations with special attention for the effect of market and environmental conditions on strategies and performance (Van Witteloostuijn et al., 1997). Processes of competition and their consequences for economic welfare are an important issue in this theorizing (Schmalensee and Willig, 1989). However, the internal functioning of organizations remains largely unexplored in this field (Tirole, 1988)

Chapter 4 deals with the impact of organizational change on advertising firm performance. Changes in organizational strategy, structure and top management team composition are related to the performance of advertising agencies. In terms of Figure 1.1, Chapter 4 thus examines effects 2,3 and 4 . The importance of organizational change pertains to the voluntarism versus determinism perspectives. On the one hand, adherents of a voluntaristic viewpoint, such as contingency theorists, emphasize the eminence of strategic change in order to be successful (Johnson and Sicholes, 1993). On the other hand, organization ecologists (Hannan and Freeman, 1977 and 1984), propagating a deterministic perspective, argue that inertia is a prerequisite for survival. Since this is a major dillemma, Chapter 4 involves a dynamic approach to the direct effect of organization and top management team factors on performance, and examines the impact of change in these aspects on company success. It is the first study to investigate the impact of organizational change on financial performance and the probability of survival, separately among small and large firms.

It is clear from the centrality of the top management team that this book is based on the voluntaristic viewpoint, though, with a deterministic flavor. Top managers are held responsible for the choice of the firms" strategy and structure, and so for company performance. However, their choice is believed to be restricted by market conditions. For instance, if economies of scale exist within a market, then firms will either enter the market at a large scale or pursue strategies that will enable them to grow fast in order to reap the economies of scale advantages

Chapter 5 imvolves the impact of top management team composition, in terms of age, firm tenure, previous industry experience and partnership, on advertising firm performance (effect 4 
in Figure 1.1). This chapter is embedded notably, in upper echelon theorizing (Hambrick and Mason, 1984), arguing that organizational outcomes, both strategies and effectiveness, are a reflection of top managers" characteristics. In this theory, observable characteristics of executives, such as their age, education and firm tenure, are suggested to refer to underlying values and frames of reference, which are important determinants of strategic choice (Hambrick and Mason, 1984), It is the first study to investigate the impact of the combination of average and spread in a top team's age and firm tenure on agency performance.

Finally, Chapter 6 summarizes the results of the empirical studies. For each of the linkages in Figure 1:1, the findings are summarized and discussed. The chapter draws overall conclusions and presents suggestions for future research.

As this introduction makes clear, different studies are undertaken to separately analyze the effect of organizational factors and top management team variables on the performance of the same set of advertising firms. Regrettably, in this thesis, an integrated analysis in which all variables addressed throughout the book are included, could not be undertaken due to data limitations, reducing the sample size below meaningful limits.

The empirical chapters are structured in such a way that they can be read independently. Each chapter extensively discusses the theory that is relevant for the subject in question. In addition, each chapter includes a section on the research sample and the analyses. The latter two sections, thus, show great overlap over chapters as the entire thesis pertains to the same industry and similar analyses are applied in Chapters 4 and 5 . However, the advantage of the independency of the chapters is that if the reader is interested in a specific chapter only, (s)he can understand this particular part of the book without having to read all other chapters or glance back at previous chapters. 


\section{CHAPTER 2}

\section{THE RESEARCA SAMPLE}

\subsection{Introduction}

This chapter presents an overview of the research sample. Section 2.1 justifies the choice of the industry. Section 2.2 discusses the differences between the samples that are used for the various studies. Section 2.3 involves the outlines of the sample. The data collection is subject of Section 2.4. Section 2.5 describes some characteristics of the sample of companies. And finally, Section 2.6 concerns the financial performance of advertising agencies.

\subsection{Choice of the industry}

The research setting of the studies described in this thesis, is the Dutch industry of advertising agencies, over the time period 1984-1994. The reason for selecting the Dutch advertising industry as the setting of the present studies is fourfold. First, though advertising is an expanding industry, few studies, other than from the marketing science approach, have been carried out in this market. Second, Dutch advertising agencies are relatively small firms, which makes this industry a suitable setting to examine the relationships at hand. In terms of entry and exit (Chapter 3), a set of small firms may be expected to be relatively dynamic. In order to examine organizational change (Chapter 4), small organizations are a well-chosen research group, as they are able to change relatively quickly so that changes may occur frequently in this sample. With regard to the study top management team composition (Chapter 5) small firms form an appropriate research sample since a relatively large part of the performance variation of small firms may be explained by the personal characteristics and preferences of their managers (Preisendörfer and Voss, 1990; Boone and Van. Witteloostuijn, 1996). The third motive for sellecting the adwertising industry is that it consists of a large number of agencies so that a large research sample can be obtained. And finally, the disposition over annual listings of Dutch advertising agencies made the data relatively easily accessible.

The data set covers a time period of eleven years, 1984-1994, which offers ample opportunity for the study of industry and firm dynamics. The decision to keep the sample restricted to an eleven year time-series is based on the limited time period in which this thesis should be finished. Constructing a data base of this stze already requires an incredible amount of time.

\subsection{Different studies, different samples}

Before describing the outlines of the research data set, it is important to mention that the 
samples of advertising agencies that are used for the three empirical studies include different numbers of observations, which in turn implies that they differ somewhat in their composition. The samples of the studies differ in size because of missing data on the sets of independent variables analyzed in the different studies: Constructing a data set that contains many variables at the firm and top management team level is extremely time-consurning and is done step-bystep. Much effort was first put into gathering information on variables that are included in each of the three studies, that is, on firm size (turnover and staff size) and the variables board size, firm age, location and ownership. The sample that resulted from this exercise constitutes the basic data set. The data set was, then, extended as much as possible with the independent variables analyzed in the various chapters. Since the information on the independent variables was not available for each advertising agency, this resulted in three samples that vary in size.

Chapters 2 and 3 make use of the basic sample and include the maximum amount of cases. Chapters 4 and 5 entail subsamples of the basic data set. The present chapter and Chapter 3 , describing the outlines of the research sample and examining the post-entry and pre-exit performance of advertising agencies respectively, both include the basic sample as only the size measures and control variables are used. Chapter 4 , analyzing the impact of strategic change on advertising agency performance, disposes of a smaller amount of cases. The first reason for this is that six organizational change variables are examined and an agency could, thus, be included in the study only in those years for which information on each of the six changes was available. Second, the number of cases diminished because the use of change variables implies the loss of the first year observation of a firm. Finally, Chapter 5, which concerns the effect of top management team composition on agency performance, has the smallest amount of observations at its disposal. This is due to the fact that an agency could only be included in the sample in those years for which of at least 75 percent of the board members' data on five personal characteristics were available. This happened to be a difficult task. Of many individwal top managers (of the entire sample of almost 1300 top executives) the necessary information was available. However, the data were rarely present for entire teams of top executives.

\subsection{Outlines of the research sample}

Advertising agencies are included in the research sample on the basis of two requirements. The first criterion consists of the possession of a Rota registration and/or adherence to one of the two industry associations, the Vea ('Vereniging voor erkende reklame-adviesbureaus') or the Pragma. The second requirement involves the availability of the annual data of the agency, i.e., the characteristics of the agency need to be reported in the main source from which the data are collected, the 'Adtormatie Bureaubijlagen'.

The Rota is a unique Dutch invention. It is an association at which agencies are registered on request, but they are accepted only if they fulfill several qualitative and financial stability 
requirements. In order to be accepted as a Rota member a demand has to be supplied to the association which must be accompanied by an annual account of the preceding year, verified and provided with a declaration of an auditor. The Vea is the strongest and oldest Dutch advertising industry association, representing primarily the larger agencies in the Dutch industry. The Pragma has been founded in 1988 and defends the interests of the smaller, independent Dutch agencies, which could no longer associate with the interests defended by the Vea. Finally; 'Adformatie Bureaubijlagen' are annual listings of the most important advertising agencies in the Netherlands.

If an agency is a Rota, Vea or Pragma member, but no data at all or not enough data are available in the 'Adformatie Bureaubijlagen' for any of the years of the time period under study, the agency is excluded from the research sample. Availability of turnover and staff size of an agency are the minimum requirements in this respect. The current sample therefore also depends heavily on the criteria that the 'Adformatie Bureaubijlagen' apply to list agencies. Until 1988, the 'Adformatie Bureaubijlage' records all agencies registered at the Rota. From 1989 onwards, all agencies adhering to the Vea and Pragma are listed as well as non-organized agencies attaining a minimum size threshold. From 1990 to 1994, Vea and Pragma members are still registered: only the minimum required size of the non-organized agencies undergoes small changes. Furthermore, 'Adformatie Bureaubijlage" receives the necessary data for their listings on a voluntary basis, by means of a questionnaire they send out every year to the agencies. This implies that when an agency does not occur at all in the 'Bijlagen' of one or several years between 1984 and 1994, or only a few variables are presented, the blanks may be caused by either the criteria applied by the 'Adformatie Bijlage' or non-response of the agency.

An agency is selected for the sample when it is or becomes a Rota, Vea or Pragma member during the eleven year period, 1984-1994. It enters the data set in the first year its data are reported in the 'Adformatie Bijlagen'. For most agencies the two criteria coincide and they enter the sample the first year they are a Rota, Pragma; or Vea member and they are listed in 'Adformatie Bijlagen'. Some agencies, however, enter the sample before they become associated to an industry association, as their information is already reported in earlier years of the 'Adformatie Bijlagen'. Finally, agencies may enter the sample one or several years after they have become a Rota, Vea or Pragma member since not enough data are available for earlier years. In this lime it happens that an agency satisfies the first criterion (possessing either a Rota, Vea or Pragma membership) from 1984 onwards but for some reason not enough data are reported in its early year(s) so that it is included in the sample only a few years later. This is the case for 22 agencies. Another complication occurs when the data of an agency are available for a certain number of years, but with an interruption of at least two years. Three agencies exhibit this anomaly. For two agencies the first sequence consists only of one year; they therefore enter the sample in the first year in which the second and longest sequence of data are avail- 
able. For one agency both sequences are equally long: this agency, which experienced internal transformations such as ownership changes in the interjacent years, exits the sample at the end of the first sequence and re-enters the sample as another agency in the first year of the second sequence.

A few exceptions to the entry rule constitute five agencies that enter the data set one or several years before they are listed in the "Adformatie Bijlagen". These agencies are at that time already presented in 'Blauwe Burogidsen' and are so-called, "profiel" agencies i.e., they are among the 80 most well-known agencies in the Netherlands. One of these agencies, a large agency, does not adhere to any of the industry associations, but is of such a size that selection is inevitable. Some smaller and less well-known agencies may also be listed in the Nieuwstribune before they are represented in the 'Adformatie Bijlagen'. However, the criteria that 'Nieuwstribune Bijlage' applies for selecting agencies are less clear than those used by "Adformatie Bijlage'. Moreover, the data in the two books do not always concorde, and it is therefore important to use one source as much as possible.

Exit from the data set may have several causes. In the present sample, four exit modes are distinguished: bankruptcy, dissolution, merger or acquisition, and finally, "alive" up to 1994 but with insufficient information being available. The first exit mode, bankruptcy, needs no further explanation. The second cause of exit, dissolution, involves agencies that have stopped their activities between 1984 and 1994 and have mentioned this to the Rota, without the exact reason of the dissolution being known. It is possible that an agency is absent from the sample in one or several years preceding the bankruptcy or dissolution, which is due to the unavailability of information in the interjacent years.

The third category of exiting firms refers to agencies who merge with a larger agency, or are acquired by and integrated within another agency. In the case of a merger, following Dunne et al. (1988) and Maijoor et al. (1995), the smallest of the merging agencies (in terms of turnover) is registered as an exit whilst the largest of the two, or the acquiring firm, continues to exist in the new form. An exception to this rule involves the situation in which the acquiring agency is the smallest of the two, but the board of the new agency consist uniquely or predominantly of board members from the acquired and largest agency. In this situation the latter, the acquired agency continues to exist while the acquiring agency exits the sample. Since the beauty and human capital studies examine the individual board member features, this seems to be the correct solution. This situation involves three agencies. It must be noted that the acquiring, but exiting, agencies were owned by multinational advertising agencies so that the owners of the new, merged, agency are again the multinationals.

The last exit mode represents agencies that are removed from the sample before 1994 due to a lack of data. Two situations may occur. First, the agency may (still) be a member of the Rota but does no longer attain the minmum size threshold to be listed in the 'Adformatie 
Bureaubillagen". And second, the agency may (still) be listed in the Adformatic Bureaubijlagen", without, however, providing the minimum required information. Since it is the choice of the agency to land in the data for the annual listings, it is plausible to interpret missing turnover data in a "Bijlage" as a bad year for the agency. Advertisers may consult the books for information on agencies and as the financial health of an agency is an important selection criterion, some agencies may have refrained from providing their turnover in order to hide a decline. Taking a quick look at the staff size values that are available in the subsequent year(s), we see that these are indeed smaller than in the preceding year.

In the following chapters, empirical studies are carried out in which entry to the research sample is used as a proxy for new establishment (Chapter 3) and exit from the data set is employed as an alternative for failure (Chapters 3 - 5). The criteria applied for entry and exit to the present data set, described above, imply that the results obtained with these data should be interpreted with care, keeping the particularities in mind. Entry to the sample is actually entry to the set of large and financially healthy advertising firms. This implies that whille some agencies have been founded one or few years before entry to the sample, several other sample entrants were established many years earlier. One may expect, then, that the group of entrants to the sample perform better, on average, than a group of new established firms. The survival analyses reported in the empirical chapters are only a first step toward a full-fletched study into the determinants of mortality in the Dutch advertising industry.

\subsection{Data collection}

The data on adherence to the Rota were taken from Rota circulaires and 'Adformatie Bureaubijlagen'. Information on Vea membership was obtained from 'Adformatie Bureaubijlagen' and annual reports of the Vea. Pragma membership was mentioned in the 'Adformatie Bureaubijlagen' and taken from there. Most information at the individual agency level, such as turnover and staff size, was collected from the "Adformatie Bureaubijlagen". Turnower and staff size data at the agency group level were gathered either from the 'Adformatie Bijlagen' or from the weekly industry joumal 'Adformatie'. The 'Blauwe Bugamor', 'Blauwe Burogidsen' and 'Blauwe Bureau Tribune" were used to fill up missing walues on these variables and to collect information on the personal characteristics of board members. Information or "se exit modes of certain agencies was collected from the industry press, received from the Rota and Scan. Information on the year of founding of the agencies was found in the Vea member guide, 'De Vea en haar leden, 1993', in the 'Blauwe Bugamor', "Blauwe Burogidsen' and "Blauwe Bureau Tribune" or obtained from the regional Chambers of Commerce.

The 'Adformatie bureaubijlagen' and the 'Blawwe Burogidsen' are annual listings of the most important Dutch advertising agencies, including several of their characteristics such as. 
name, geoguaphic location, clients served, services delvered, number of employees, ownership, boatd members and turnover.

\subsection{Description of the industry and sample}

This section presents a description of the sample. First ilustrative general information an the size of the sample and the industry is provided. Second, some statistics at the industry (sample) level are provided, ite, concentration, top ten rankings and some entry and exit figures. And finally, at the agency level, sample descriptives are given.

\subsubsection{The size of the research sample}

The research sample consists of 318 advertising agencies. A registration at the Rota, as well as a membership of one of both industry associations, is indicative of a qualitatively and financially healthy organization, which implies that the sample is biased toward the larger and financially healthy organizations. It is assumed by industry experts that nearly all agencies of a reasonable size are captured by the applied selection criteria and that the over 300 agencies included in the research sample account for above 70 percent of industry turnover. Whereas the whole Dutch advertising industry consisted in 1994 of more than 9,000 agencies (CBS, 1996), most of these are extremely small firms. For instance, in 1992, the CBS counted 9034 firms of which 75 percent were one-person companies and 93 percent employed a maximum of 4 people. These figures point to the existence of low entry barriers in the advertising market and the, therefore, high number of entrants and exiters. Having several clients is sufficient for an individual to start an advertising agency, however, losing one or few of these clients while not succeeding in attracting new adwertisers, may immediately lead to exit from the market.

A number of the 318 advertising agencies is not in the sample during the whole time frame because of founding after 1984 , failure before 1994 and missing observations. This implies that the number of advertising lirms in the sample varies per year, from 171 to 245 , with an annual average of 211 agencies. The data set, thus, consists of a total of 2321 observations. The density (the number of firms) in the entire industry in the segment of agencies with a minimum of five employees (in the sample 95 percent of the agencies employ five or more employees), during the time period and as counted by the CBS, ranges from 384 to 679 , with an average of 505 agencies. Figure 2. 1. compares the sample density with the industry density of advertising furms with five or more employees, during the time period under study, $1984-1994$.

A comparison of the sample and industry density reveals a strong positive correlation ( $86, p$ $<$. 01.). However, the growth in the sample density (net entry) is insignificantly, and even negatively, related to net entry in the entire industry segment $(-36)$. Anyway, the comparison between the sample dynamics and the industry-level dynamics is rather meaningless because the CBS includes not only the advertising agencies, as they are studied in this thesis in the 
category of advertising agencies (reklame- en advertentiebureaus'), but also studios, windowdressing companies, post sending- and address agencies and all kinds of suppliers. The CBS is unable to split the group up into smaller segments. Hence, the CBS data include many different and non-competing markets, whereas the current sample is composed of direct competitors only.

Figure 2.1: $\quad$ Sample and industry densiby

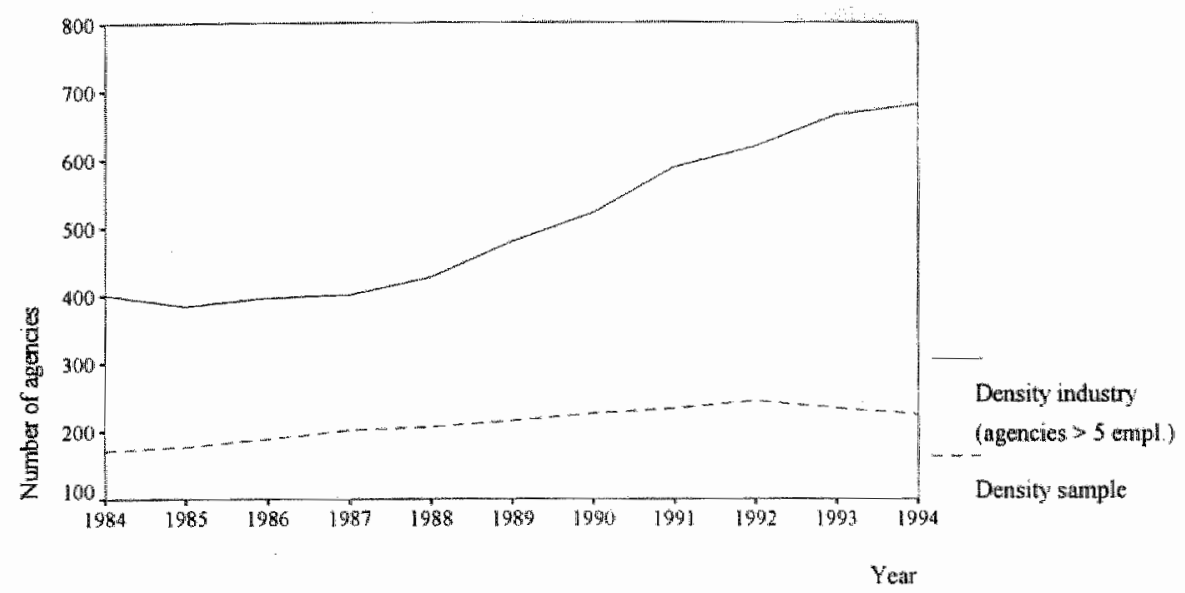

The conclusion is that - also in view of the fact that, as already mentioned above, industry experts agree that most advertising agencies of a certain size are covered in the data set - the present sample seems to give a better indication of the advertising agencies operating in the Netherlands than the data provided by the CBS. To estimate the size of the sample relative to the size of the industry, it is for the same reason meaningless to compare the total turnover of the advertising agencies in the sample with the total industry turnover, as reported by the CBS. It may, however, taking a few drawbacks into account, be useful to compare the total turnover obtained by the advertising agencies in the sample with the amount of money spent on advertis. ing in the Netherlands.

The total turnover of the (groups of) advertising agencies included in the study' ranges from 3.6 billion Dutch guilders (constant 1985 prices) in 1984 to almost 6.7 billion Dutch guilders in 1992. The total advertising expenditures in the Netherlands which include the insertion- and production costs of all advertising in the Netherlands, as provided by the Vea and computed by

The, the total furnower of all groups of agencies and afl individual ageneiss (not belonging to an agency group) in the sumple, and replacing missing values of agency groups with the turnower of the langerst group mownem. 
the Data Direction bv until 1993 and by Twinfo in 1994 varies from 5.4 billion of Dutch guilders (constant 1985 prices) in 1984 to 10.3 billion Dutch guilders in $1994^{2}$. The two curves are shown in figure 2.2

Figure 2:2: Sample turnover and adwertising expenditures

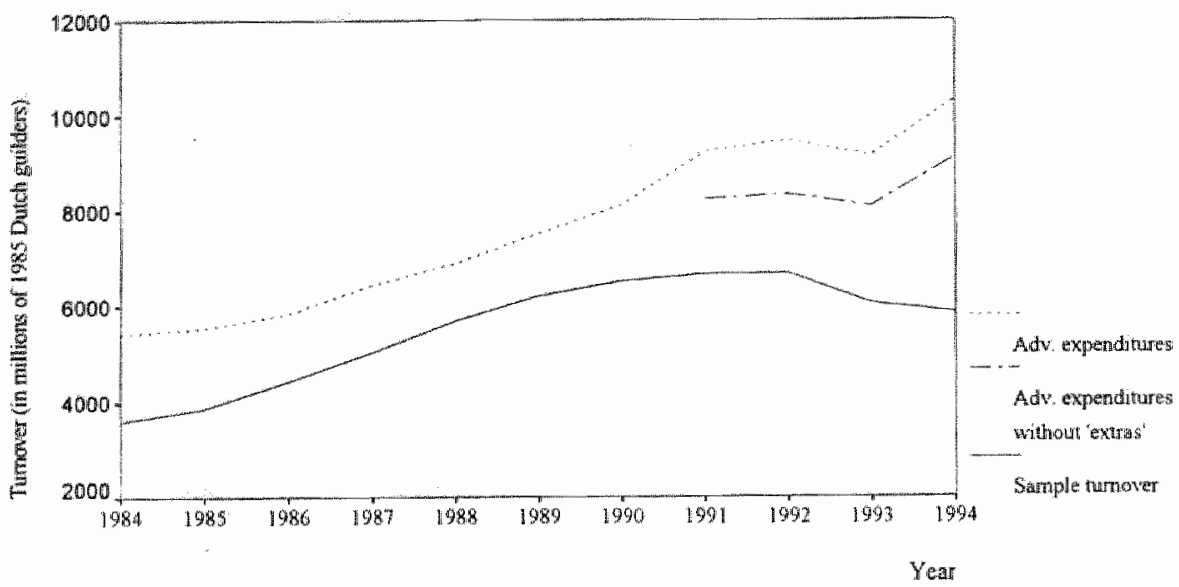

The discrepancy between the two curves may be explained by two main causes. Most important is the fact that the insertion costs refer to all insertions, thus also those not mediated by advertising agencies, as for instance address books, fairs and exhibitions, personal announcements (e.g, notices of births and deaths), classified advertisements (e.g. cars, furniture) and all other advertising directly carried ont by firms or individuals. Especially smaller companies do not make use of advertising agencies in order to place publicity and recruitment ads. Unfortunately, the size of these, to the study, irrelevant advertising expenses are not specified. Only the annual expenditures on fairs and exhibitions are reported separately from 1991 and 1994. These expenses make up about $8 \%$ of the total expenditures and refer to the costs of renting the location and the production costs (building and furnishing of stands, stand personnel and facilities, etcetera).

In figure 2.2, a separate line is displayed from 1991 - 1994 in which the expenses on fairs and exhibitions and address books are deducted from the total advertising expenditures. The second explanation for the divergence between the two curves involves the criteria applied for selecting agencies for the sample. They imply that non-organized agencies and agencies that

\footnotetext{
2 For astudy dealing with predicted and actual advertising expenditures following the introduction of private broadcasting in the Nothethonds, see, e.g. Alsem (1991) and Alsem and Leellang, 1994).
} 
adhere uniquely to other industry organizations, such as the DMDN (Direct Marketing Institute Netherlandls), SPIN (Sales Promotions Institute Netherlands) and VPRA (Verenging Public Relations Adviesbureaus), and their turnover, are not included in the sample. The non-organized agencies represent the huge number of small, one of two person firms in the industry. which can hardly call themselves advertising agencies and which are not listed in industry reports or listings. Furthermore, they cannot, for the time being, be considered serious compet:itors for the larger advertising firms. The agencies which adhere exclusively to 'other' industry associations are excluded from the sample as they were not listed in the sources in prior years and only sporadically in later years.

The turnover of the (groups of) advertising agencies in the sample diminishes at the end of the time period, compared to an increase in the total advertising expenditures. A sinilar divergence of curves is observed in figure 2.1 representing the number of agencies in the sample and in the industry. The discrepancy may be partly caused by the fact that during the last few years of the time period (i) the number of non-organized large agencies has increased and (ii) the number of specialized agencies adhering exclusively to "other industry associations" (and not listed in the consulted sources) has progressed.

The advertising agencies making up the research sample take account of an average of 73 percent of the entire advertising expenditures with a maximum of 83 percent in 1989 and a minimum of 57 percent in 1994. Subtracting the spendings on 'fairs and exhibitions" and address books from the total expenditures increases the relative size of the sample between 1991 and 1994 with an average of 9 percent, to 64 percent in 1994 . Several aspects indicate that the observed percentages come close to reality. First, the total advertising expenses still comprise more advertising than which is mediated by advertising agencies. Second, many expenditures on sales promotion activities are not included in the total advertising expenditures. And last, but certainly not least, industry experts assume that nearly all agencies of a reasonable size are captured by the applied selection criteria and that the agencies included in the research sample account for above 70 percent of industry sales. With the applied selection criteria the largest and most important segments of the entire advertising industry are captured.

\subsubsection{Concentration}

The concentration in the Dutch advertising industry is measured at two levels. Nowadays, many agencies are organized in "groups", i.e., a mother, full-service, agency is surrounded by several specialized, satellite, agencies. The groups sometimes form integrated agencies, many of which only provide sales data at the group level. The concentration in the market is for that

\footnotetext{
In January 1995 , the DMIN, SPIN and NPQ (Dutch Malonder Association) merged, ctsanging their tuame into DMSA (Dutch Association for Direct Marketing, Distance Selling and Saldes Promotioni).
} 
reason computed both at the individual agency level as well as at the agency group level

Two measures are used to assess the concentration in the advertising industry: the concentration ratio $\mathrm{C}_{\mathrm{n}}$ and the Hirschman-Herfindahl index ( $\mathrm{H}$-index), both of which are generally applied in the field of industrial organization. The concentration ratio $\mathrm{C}_{\mathrm{n}}$ reflects the cumulative market shares of the $n$ largest firms in an industry. In theory $n$ may refer to any number of firms, but in general the market shares of the largest 4 , and less frequently 8 or 20 , firms in a market are analyzed. While the $\mathrm{C}_{n}$ ratio only takes account of a limited number of (large) firms, the Hirschman-Herfindahl index includes all firms in an industry to obtain a market's concentration level. The H-index is defined by the sum of the squared market shares of all firms in a market. It"s valke ranges between 0 and 1 . The higher the values of the $C_{n}$ and the $H$-index, the stronger is the concentration and the more unequal is the firm size distribution in the industry.

Table 2.1 presents the concentration levels in the Dutch advertising market in the period 1984 - 1994. The present analysis is restricted to the reproduction of the $\mathrm{C}_{4}$ and $\mathrm{C}_{8}$. The $\mathrm{H}$ index has also been computed, however, it suffices to mention that the $\mathrm{C}_{4}$ and the Herfindahl index are strongly correlated. Both concentration measures of the individual agencies and the groups of agencies show a correlation of 76 and 89 respectively.

Table 2, 1: Density and concentration in the research sample

\begin{tabular}{|c|c|c|c|c|c|}
\hline \multirow[b]{2}{*}{ Yenr } & \multirow[b]{2}{*}{$N$} & \multicolumn{2}{|c|}{ Individual agency level } & \multicolumn{2}{|c|}{ Agency group level } \\
\hline & & $\mathrm{CH}^{4}$ & $\mathrm{CB}$ & $\mathrm{CA}$ & $\mathrm{CB}$ \\
\hline 1984 & 171 & $12.64 \%$ & $23,27 \%$ & . & - \\
\hline 1985 & 177 & $12.57 \%$ & $23.40 \%$ & . & - \\
\hline 1996 & 188 & $12.61 \%$ & $21.27 \%$ & $20.50 \%$ & $31.60 \%$ \\
\hline 1987 & 201 & $12.28 \%$ & $20.230 \%$ & $22.190 \%$ & $34.41 \%$ \\
\hline 1988 & $20 \%$ & $13,090 \%$ & $20.27 \%$ & $22.25 \%$ & $35.44 \%$ \\
\hline 1989 & 215 & $12.33 \%$ & $12.61 \%$ & $21.73 \%$ & $34.76 \%$ \\
\hline 1990 & 226 & $11.80 \%$ & $18.92 \%$ & $21.86 \%$ & $34.97 \%$ \\
\hline 1991 & 233 & 11.068 & $18.35 \%$ & $22.41 \%$ & $35.05 \%$ \\
\hline 1902 & 24 & $11390 \%$ & $18.41 \%$ & $22.16 \%$ & $34.65 \%$ \\
\hline 1963 & 23.4 & $111.94 \%$ & $18.81 \%$ & $21.70 \%$ & $34.05 \%$ \\
\hline 1944 & 225 & $12.51 \%$ & $19.85 \%$ & $22.34 \%$ & $35.15 \%$ \\
\hline
\end{tabular}

The market shares of the individual agencies and the groups of agencies are calculated using their gross income (in 1985 Dutch Guilders). Gross agency income is the difference between the sum of money invoiced to clients and the amounts paid to suppliers (on behalf of the 
clients) (Adformatie Bureaubijage, 1995). In the renainder of this book the term income is used to denote the more unfamiliar term gross agency income. The income of the four and: eight largest individual and groups of advertising agencies are compared with the total sample income, se., the sum of the income of all individual agencies and groups of agencies in the sample. The concentration of groups of agencies starts only by 1986 since group figures were not available before that year.

The computation of the $\mathrm{C}_{4}$ and $\mathrm{C}_{\mathrm{s}}$ of the individual agencies is somewhat hindered by the fact that, either in all years under study, or for some of the years, several large agencies only provide their group income and do not report the income of group members separately. These agencies put forward that they are so much integrated among group members that it is difficult to provide individual income. The consequence is, however, that they cannot be included in the individual $\mathrm{C}_{4}$ and $\mathrm{C}_{8}$ and the concentration ratios may thus be a little underestimated in the years in which the omissions occur. However, the damage caused by this inconvenience remains limited since the market shares of the larger agencies do not diverge very much, as will become clear from a comparison between the $\mathrm{C}_{4}$ and $\mathrm{C}_{8}$.

Calculation of the concentration of the groups of agencies is troubled by the incomplete and inconsistent information on the group compositions. The information on group compositions was incomplete in 1986 - 1990, which increased the incommodity, also observed in later years, of inconsistent reporting of group members. Some groups included the income of a small agency in which it had an interest in one year, but omitted it the next year. These few drawbacks, notwithstanding, the measures provided in Table 2.1 give a good picture of the actuat concentration levels in the industry. The Dutch advertising industry appears to be a moderately concentrated market. While the $C_{4}$ of the individual agencies varies from a maximum of 13 percent in 1988 to a minimum of 11 percent in 1991 , the $C_{B}$ ranges between 23 and 18 percent in 1985 and 1991 respectively. These percentages point to a rather equal size distribution of the individual agencies. Computation of the Herfindahl index confirms this observation. The index ranges from .0154 to 0114 during the time period.

The market shares of the four largest agencies, the $\mathrm{C}_{4}$, decline slightly relative to the den sity. It seems as though there is a limit to the size of the individual advertising agencies, which is in line with the existence of agency "groups" in the industry. Having reached a certain size,

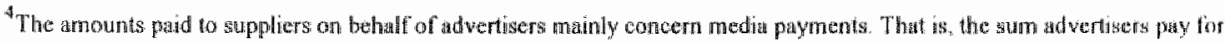
media space is paid to the agenoy who iransfers it to the media. Advertising angencius receive a commission oner the

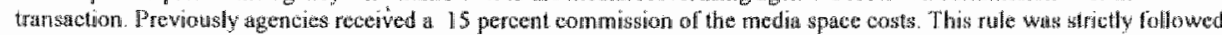
in torver years, but recently challenged by advertisers. Before 1990 ind histryearbooks provided the turnover of angenciew: from 1990 on watds the gross income of agencies is displayed. In the research sample the a verage ratio of tumower to gross income is 6.76 (turnover gross ineome *6.76). While in agency turnover the costs of media space is inaluded, tugenty income inctudes only the commitission on media spate.
}

"Missing walues of group incomes are fepluced with the incone of the largest group member. 
Individual agencies are unable to keep up with the growth pace of the industry (advertising expenditures). This is especially due to the fact that an agency is only allowed one client per industry. So, e.g, you will never find two car accounts within the same agency. Since specialized services such as direct marketing and sales promotion activities started gaining in importance, and the problem of conflicting accounts became even more stringent, the large agencies reacted by splitting up in several parts - the parent agency and several specialized, satellite, sister or subsidiary agencies - organized as a group of agencies ${ }^{6}$. As a group, agencies can more easily keep up with the growing demand. The $\mathrm{C}_{4}$ and $\mathrm{C}_{8}$ in terms of agency groups over the 1984-1994 period has indeed remained rather stable in face of a slightly increasing market. The market shares of the 4 and 8 largest groups of agencies in the Dutch market varies around 21 and 34 percent of total gross income respectively. In terms of groups of agencies, the market thus appears to be substantially stronger concentrated than in terms of individual agencies. A group of agencies may obtain growth not only because each individual group member can grow but the number of agencies that is part of a group may progress as well. Examination of the separate group members indeed learns that the group growth is mainly achieved by the smaller, specialized agencies as well as by frequently occurring acquisitions or mergers.

\subsubsection{The top ten of advertising agencies}

Similar to the concentration in the Dutch advertising industry, the top ten of advertising agencies is given for the individual agencies as well as for the groups of agencies; shown in Table 2.2 and Table 2.3 respectively. The two top tens of advertising agencies between 1984 and 1994 are also calculated on the basis of gross agency income. The market share of each agency is given in brackets ${ }^{7}$. It is possible that a higher income is achieved with a smaller staff than a lower income. When two agencies display equal incomes, their respective staff sizes are used to decide the ranking. Unavailability of income data at one of the two levels causes the absence of certain agencies in specific years in either of the top tens. For instance, refraining from reporting separate incomes of individual group members excluded Ogilvy and Mather from the individual rankings in all years but 1991, omitted McCann Erickson from 1984-1990 and PPGH/JWT from 1988-1991.

Both the top ten of the individual agencies and the top ten of the groups of agencies reveal

\footnotetext{
${ }^{6}$ Perwond contrient by $\mathrm{H}$. Nienan, director af the industry awsociation the Vea (1994),

${ }^{7}$ Annual market shares are the percentage of the total annum income of all agencies in the sample taken nuto account by the thigentey.
} 
to be rather stable ower the ten-year time period. Both rankings are headed in nearly all years by FHV/BBDO, in group terms BBDO Netherlands. At the group level the BBDO group largely takes the lead compared to the other groups.

Table 2.2: The top ten of indiwdual Dwch advertising agencies: $1984-1994$

\begin{tabular}{|c|c|c|c|}
\hline Ramking & 1985 & 1986 & 1987 \\
\hline \#. FHVBBDO (3.77\% & FHWDBDD $(3.81 \%)$ & FHV/3BDO (3. $74 \%$ & PMSWWhak $(\mathrm{G}, 6 \mathrm{~B})$ \\
\hline 2. Lintan $(313 \%$ & $7 x h(3.03 \%$ & PMSUWUYR $(3.66 \%)$ & FHVIBQDO $\left(3.5 \mathrm{~s}^{2}, 6\right)$ \\
\hline 3. Y\&R (2.99\%) & Lintas $(3.01 \%)$ & L.intas $(2.80 \%)$ & Lintuse $(2,680)$ \\
\hline 4. JWT $(279 \%)$ & WEWAL $(2.72 \%)$ & NQRULB $(2.41 \%)$ & Prat A Alam (2.34\%) \\
\hline 5. N\&WhIS $(2,71 \%$ & $\operatorname{MWT}(2.72 \%)$ & Prad $A^{*}$ dian $(223 \%)$ & Statchates sualchu (2.19\%) \\
\hline 6. PMSvW (2.68\%) & $P M S \cup W(2.72 \%)$ & Santehi a Sartwh $(2.22 \%)$ & ARA $(2.16 \%)$ \\
\hline 7. Publicis $A^{2}$ dam $(2.65 \%)$ & PPCHLMoussult (298\%) & $\operatorname{ARA}(2.15 \%)$ & NEWILE (1.96\%) \\
\hline 8. Prad Adlam $(2,59 \%)$ & Prablicis A dam $(2,41 \%)$ & WWT $(206 \%)$ & 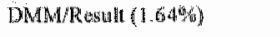 \\
\hline 9. PPGHMOAssaut (234\%) & Drad A dam $(2.27 \%)$ & DMMRRentit (1.79\%\%) & Geutlaker Oerlemains (1.61\%) \\
\hline 10. DMMfResult (2.32\%) & AlRA $(2.20 \%)$ & Publicis A'dam (1.67) & DOB Nedillan $(1.60 \%)$ \\
\hline
\end{tabular}

\begin{tabular}{|c|c|c|c|}
\hline 1988 & 1989 & 1990 & 1991 \\
\hline 1. PMSWW/ d R $(407 \%)$ & PHW/BEDO $(3.83 \%)$ & FHW/BBDO $(3.89 \%)$ & FHV \\
\hline 2. FHบBBDO (3.78\%) & PWSYWYQR (3.70\%) & PMSWWIY\&R $(\$ .52 \%)$ & 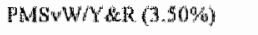 \\
\hline 3. Prad A'dam $(2,71 \%)$ & Prad A'dam $(2,47 \%)$ & Plad Adam $(2.220 \%$ & NBWWAB $(203 \%)$ \\
\hline 4. Suatdie Sathichi $(2.53 \%)$ & Snatchi santehi (2.33) & Satchi \&atathi $(2.17 \%)$ & Publicis FCBPrad (2.02\%) \\
\hline 5. $\operatorname{Lintan}(2,16 \%)$ & Lirbas $(1.95)$ & N\&WLB $(2.00 \%)$ & Ogilvy Nather (2.00\%) \\
\hline 6. NRW/LB (1.72\%) & N\&W/LS (1.92) & Lintis $(1.80 \%)$ & 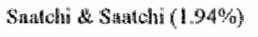 \\
\hline 7. Gendekthor Oerlemans $(1.71 \%)$ & Publicis. FCB $(1.86)$ & Publicing $\mathrm{FCB}(1.74 \%)$ & MaCaur-Enicksson $(1.69 \%)$ \\
\hline 8. Publicis $\mathrm{FCB}(1.59 \%)$ & Result (1.55\%) & Resulit $(1.58 \%)$ & Lintas (1.66\%) \\
\hline 9. BEDOBC $(1.56 \%)$ & $\mathrm{BBDOB.C}(1,41 \%)$ & Geudaker Oerthentans ( $1.59 \%$ ) & 敗esult $(1.58 \%)$ \\
\hline for, Resuli $(1.53 \%)$ & Getudeker Oarlesmans ( $1.36 \%$ ) & BEOO B.C. (1.36\% & HBOO BC: (1.22\%) \\
\hline
\end{tabular}

1992

\section{PMSWNTR $(371 \%)$}

2. THVIBEDO $(3.00 \%)$

3. PICHUTW $(2.75 \%)$

4. NWWIB (1.93\%)

5. Resull $(1.86 \%)$

5. Puhlicis HCB/prad ( 1 .

7. McCartw rickson $(1.71 \%)$

10. Ogilny \& Mather $[1.53 \%$ )
8. DMBSE $\left.(16)^{10 \%}\right)$

9. Lintus $(1.5 \% \%)$

\section{3}

\begin{tabular}{|c|}
\hline FHWBBDO $(3.46 \%)$ \\
\hline 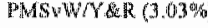 \\
\hline PPGH/JWT (2.840\%) \\
\hline Rresult $(2.21 \%\}$ \\
\hline NRWWAB $(2.02 \%$ \\
\hline
\end{tabular}

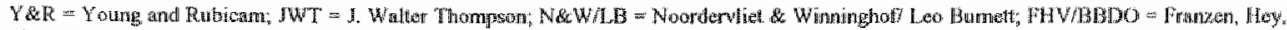

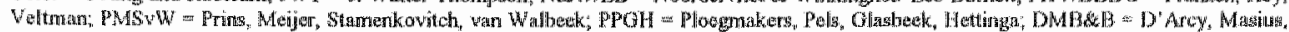

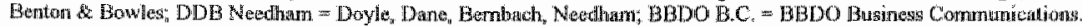

\author{
FHWBBDDO $(3.63 \%$ \\ PMSWWY \& $(3,20 \%)$ \\ PPOHJWT $(2,99 \%)$ \\ Ficstitl $(2.60 \%)$ \\ DMB B $B(2.16 \%)$ \\ NeWLE ( $4.970 \%)$ \\ Publisis FCB/3rad (1.64\%) \\ DDB Nedham (1.5\%\%) \\ Camparyon (1 $570 \%$ \\ Lintas $(1.52 \%)$
}


Table 2.3: The top fen of Dutch odwertising agency groups, 1986-1994

\begin{tabular}{|c|c|c|c|}
\hline Runking $19 \% 6$ & 1987 & 1988 & 1989 \\
\hline 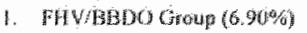 & 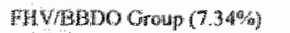 & IFHWBODO Group $7.38 \%$ & FHUABDO Group $(7.32 \%$ \\
\hline 2. Y\&R Crobut $(4.46 \%)$ & 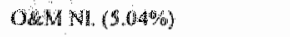 & Owerid Group $(5.10 \%)$ & Overtad Group $(5.16 \%)$ \\
\hline 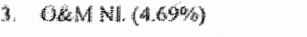 & Oyerad Gromp $498 \mathrm{~kg}$ & YER Grong (4.98\%) & Y L R Group $(4,92 \%)$ \\
\hline 4. Oyarya Gromp (4.05\%) & 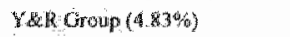 & 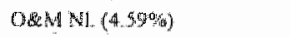 & Ost N N $(4.33 \%$ \\
\hline 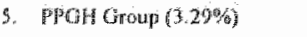 & Lintas Group (4.14 & PPCH Group (4.25\%) & Lintas Grourp $(4,06 \%)$ \\
\hline 6. Lintats $(2,80 \% \%)$ & PICH Grotap $(9.53 \%)$ & Limes Group $(9.690 \%)$ & PPGH/WWT Group $(3.83 \%)$ \\
\hline 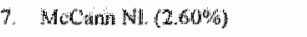 & McCann N $\left(236^{\circ}\right.$ \% & ARA Geoup $(2.72 \%)$ & ARABDDP Group $(2.72 \%)$ \\
\hline 8. Now & 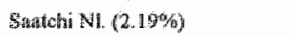 & Sasatehí N: (2.53\%) & Publicis $\mathrm{fCB}(2.42 \%$ \\
\hline 9. Enatchi Mi, $(2.22 \%)$ & ARA Croup $(2.18 \%)$ & Pullilicis $(2.16 \%)$ & Sanatchi Mil (2.33\%) \\
\hline 10. ARA Grows $(2.15 \%)$ & NIELAS $(196 \%)$ & McCsunt-Lerickson (2.08\%) & Gitey Group $(2.23 \% \%$ \\
\hline 1990 & 1901 & 1992 & 1993 \\
\hline 1. BBDO Nederlatad $(7.51 \%)$ & BBDO Nederland (7.03\%) & BBDO Nederland ( $6.89 \%)$ & BBDO Neder:land $(7.30 \%)$ \\
\hline 2. PMS wW/ & PMSWWrYR (\$.93\%) & Y\&R Group (5.79\%) & Y\&R Group (5 36\%) \\
\hline 3. Oxerad Gorop $(489 \%)$ & Owarad Group $(5.50 \%)$ & 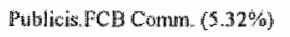 & Publicis. FCBPrad MU $(4.96 \%)$ \\
\hline 4. O\&W NL $(4.30 \%)$ & OeMN N $(3956)$ & Lintata NI, Group $\left(4,16^{\circ}\right)$ & OsM NI. (4.08\%) \\
\hline 5. Hintas NI. Group $(4.15 \%)$ & 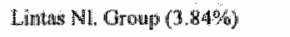 & PPGHJWT Group $(399 \%)$ & Lintas $\mathrm{BV}$, Group $(3.85 \%)$ \\
\hline 6. PPCHWWT Gromp $(3.69 \%$ & ppoHAwT Gronp $(3.74 \%$ & $0 \& \mathrm{NN} .1(3.71 \%)$ & PPoHJWT Group ( $3.82 \%)$ \\
\hline 7. ARA/BDDP Grontp (2.95\%) & ARABDDP Group $(2.83 \%)$ & ARABDDI (Troup $(264 \%)$ & Grey Comm Oroup $(235 \%)$ \\
\hline 8. Fublicis $7 \mathrm{CCS}(2.32 \%)$ & MeCom-Erickson (2.23\%) & MCCaden-Ericksann N1. (2.18\% & ARABDDD Group $(2.33 \%)$ \\
\hline 9. TBWA $(2.26 \%)$ & Grey Group $(2.17 \%)$ & Congy Compra $(2.08 \%)$ & DDB Neadlyam $(2.21$ (1) \\
\hline 10. Grey Group (2.25\%) & DDANewhan $(2.10 \%)$ & DDB Neetharm $(2.05 \%)$ & Restl $(2.21 \%)$ \\
\hline
\end{tabular}

\section{4}

1. BBDO Nederian (164\%)

2. Y\&k Gromp (3.6\%)

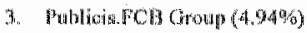

4. ORAM N1 (4.13\%)

3. PPOH

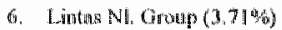

7. Resalit $\{2,690 \%$

3. Crsy Comm Choup $(2.51 \%)$

9. DMBSB (2.39\%

10. MoCunnurrackion N1. (2.20\%)

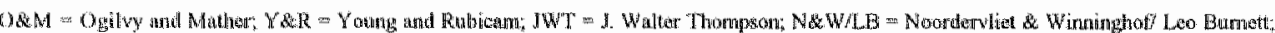

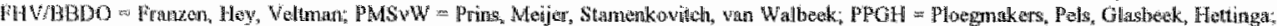

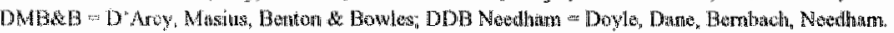

At the individual level, the difference between the first and second agencies is much smaller which results in an occasional shift of the first place. Apart from a few exceptional exchanges of places, the top 5 of both rankings hardly changes. At the tails of the rankings a bit more variety is observed. Furthermore, at the group level, the top ten exclusively consists of large 
multinational agencies which are also among the top agencies in many countries around the world, and which have been at the top since a long time. The top of the individual agencies mainly consist of the "mother' agencies of the groups. However, while the 'grroup top" is difficult to penetrate, a few independent agencies succeed in obiaining a place among the "individual top ten'. Especially noteworthy in this respect is the case of Result. The agency mounts from a tenth place in 1984 to a fourth ranking in 1994 . By the end of the time period, this agency is even large enough to compete with groups of agencies. In 1993 Result makes it's apparition in the top ten, at the tenth place; in 1994 it moves up to the seventh ranking.

Several mergers have taken place between top ten agencies during the time period under study. In 1986 PMSWW and Y\&R merged into PMSVW/Y\&R. While this did not yet result in a first place on the individual top ten ranking in 1986, it did in 1987. Another merger took place between PPGH/Moussault and JWT in 1988. The new agency, PPGH/JWT, is excluded from the individual agency ranking from 1988 through 1991 (due to missing observations), but in 1992 it reappears at a third place. At the group level, the merger leads to a promotion from a sixth place in 1987 to a fifth place in 1988 , but it had to regain it's sixth ranking anew in 1989. Because of the merger the agency (group) lost a few large clients caused by conflicting accounts (Adformatie, 1990).

A last merger involves Prad and Publicis.FCB who integrated in 1991 into Publicis FCB/Prad. At the individual level, the merger did not bring about growth in market shares nor a higher ranking. At the group level, the merger produced a growth in market shares, but again no promotion in ranking. This is, however, due to the fact that the market shares of PMSWW/Y\&R increased even stronger in this period, mainly because it included several small agencies in it's 1991 group income which it did not count in its former years" group income.

The top ten clearly illustrates that the larger agencies obtain growth mainly by merger and acquisition. Two examples of growth by acquisition are ARA who, thus, improved it's ninth place ranking in 1987 to a seventh place in 1988 and Lintas who advanced from a sixth place in 1988 to a fifth place in 1989.

\subsubsection{Entry and exit}

In terms of entry and exit the sample of advertising agencies appears to be rather dynamic. Table 2.4 summarizes general entry and exit information on the sample. A third of the 318 agencies (108 firms)is included in the data set during the whole time period under study, 1984 1994. These are called "incumbent agencies". The next third of the advertising firms that make up the sample (117 agencies), enters the data set after 1984, and is still in the data set by 1994 . These are referred to as entrants. Furthermore, almost 20 percent of the agencies (63 firms) exits the sample before 1994 but are included in the data set in 1984. These agencies are the 
exiters. Finally. 10 percent of the companies (30 agencies) enter and exit the sample during the eleven year time period and have been labeled "short-lived agencies"

\section{Table 2. S: Sample infomation}

\begin{tabular}{|c|c|c|c|c|}
\hline Goup & $\mathbb{N}(3)=100 \%$ & $\begin{array}{l}\text { Numbet of whervations } \\
\left(2321=100^{\circ / 4}\right)\end{array}$ & $\begin{array}{l}\text { Mean years } \\
\text { In sample }\end{array}$ & $\begin{array}{l}\text { Meanasy founding } \\
\text { year }\end{array}$ \\
\hline Iricumbents & $108(34 \%)$ & $1188(51.2 \%)$ & 11 & 1966 \\
\hline $\begin{array}{l}\text { Entrants } \\
\text { (untin } 1994 \text { in sarmple) }\end{array}$ & $117(96.8 \% 6)$ & $6.57(28.3 \%)$ & 6 & 1981 \\
\hline 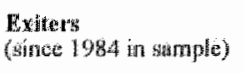 & $63(19.8 \%)$ & $351(15.1 \%)$ & 6 & 1970 \\
\hline 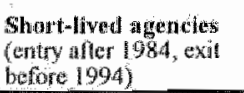 & $30(9.4 \%)$ & $125(5.4 \%)$ & 4 & 1981 \\
\hline
\end{tabular}

Table 2.4 further shows that both entrants and exiters are in the sample during six years on average, while the "short-lived agencies" agencies are only included in the sample for an average time period of four years. Furthermore, the incumbents are the oldest agencies, founded on average in 1966, followed rather closely by the exiters, having an average age of 27 years. The entrants and "short-lived agencies" are, logically, the youngest agencies of the sample, founded on average in 1981.

Table 2.5 differentiates the 93 exiting agencies (exiters and "short-lived agencies") into different categories and compares their size with the size of surviving agencies.

Table 2.5: Categories of exiting advertising agencies

\begin{tabular}{|c|c|c|c|c|c|}
\hline & Bunkeuptoy & Dissolationil & $\begin{array}{l}\text { Menger or } \\
\text { actuisition }\end{array}$ & $\begin{array}{l}\text { Inswaflichent } \\
\text { duta }\end{array}$ & Survivoirs \\
\hline$N(3)$ & 15 & 10 & 31 & 37 & 225 \\
\hline Ineame: & $\begin{array}{l}2.26 \\
(1.74)\end{array}$ & $\begin{array}{l}2.32 \\
(1.93)\end{array}$ & $\begin{array}{l}4.41 \\
(4.95)\end{array}$ & $\begin{array}{l}1.22 \\
(93)\end{array}$ & $\begin{array}{l}3.62 \\
(4.65)\end{array}$ \\
\hline Hof onplogees ${ }^{2}$ & $\begin{array}{l}14.77 \\
(8.08) \\
\end{array}$ & $\begin{array}{l}14,82 \\
(10,40)\end{array}$ & $\begin{array}{l}23.41 \\
(2140)\end{array}$ & $\begin{array}{l}7.89 \\
(4.14) \\
\end{array}$ & $\begin{array}{l}20.43 \\
20.81)\end{array}$ \\
\hline
\end{tabular}

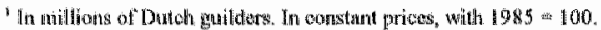

"Awerage vallies are teported with standard deviations in parenthesis.

The table reveals that the dominant cause of exit from the sample constitutes lack of data (37 agencies) and merger or integration within another agency (31 agencies). Furthermore fifteen agencies of the sample went bankrupt during the 1984-1994 period. And finally, ten agencies terminated their activities for one reason or another in a certain year between 1984 and 1994. In accordance with the distribution among exit modes Dunne and Hughes (1994) report that take-over was the most prevalent form of exit among a sample of U.K. firms (66 percent). 
Apart from the merging agencies, the exiting agencies are rather small in size. Especially the agencies exiting because of a lack of information are small. This is logic, however, since their exit is generally due to an insufficient size to be included in the "Adformatie Bijlage". Bankiupt and dissoluted firms are about similar in size. With average incomes of around 2.0 million Dutch guilders and a mean staff size of 10 - 15 employees, they are about half the size of merging agencies. The latter group of exiters are also larger, on average, compared to the average surviving agency. Dunne and Hughes (1994) also found that liquidated firms were relatively small companies and that medium-sized firms were most prone to take-over. For a detailed analysis of the entry and exit dynamics of the sample, the reader is referred to Chapter 3 .

In Chapters 4 and 5 empirical analyses are carried out using failure as the dependent variable. In these studies, failing agencies refer to bankrupt, dissoluted and "insufficient data" exiters. As Table 2.5 makes clear, of the total data set, 37 firms exit because of insufficient data, whereas 25 agencies go bankrupt or are dissoluted. While it was previously argued that a lack of data could be interpreted as a bad year for the firm, and passing below a minimum size threshold may also be interpreted as a form of failure, nevertheless, by using this proxy for exit. possible relationships examined in the following chapters may be somewhat underestimated.

\subsubsection{Sample descriptives}

The remainder of this chapter is devoted to sample descriptives. Table 2.6 presents descriptives of all variables used in this book. The table also mentions the chapters that deal with the variables. For the exact computation of the variables the reader is referred to the relevant chapters. Table 2.6 shows firm-year statistics - i.e, the descriptives are based on all observations in the sample. Firm statistics - i.e., measures based on the aggregate values (means) of the agencies over the time period they are included in the sample (aggregate level) hardly differ from the observation descriptives. The discussion, therefore, focuses exclusively on the descriptives at the observation level. The second column of Table 2.6 explains the computation of the variables. The reader is referred to the specific chapters for more detailed description of the variables.

Starting with a few general variables, the first observation is that the advertising agencies are in the research sample for a duration of 7.3 years on average, with a maximum of even years and a minimum of one year. The average founding year of the agencies is 1970 . The oldest agency in the sample is founded in 1837, while the youngest agencies started in 1993 The majority of the agencies, 72 percent, is seated in the "Randstad", proxied by the provinces of North Holland, South Holland and Utrecht. The remaining agencies are dispersed over other regions in the Netherlands. 


\subsubsection{Agency size and performance}

Dutch advertising agencies vary strongly in terms of size, but are rather small in general. The size of the individual advertising agencies in the sample ranges from 159 to 2 employees, with an average staff size of 19 employees. About 74 percent of the firms in the sample employs twenty persons or less. Only seven percent of the agencies has a staff of more than 50 employees. In terms of annual income, a smilar picture emerges. The income ${ }^{x}$ of the agencies vary from 37.50 to 17 million Dutch guilders, with an average of 3.38 million Dutch guilders. About 70 percent of the agencies in the sample earns less than 3 million Dutch guilders annually, while only 8 percent achieves an income higher than 10 million Dutch guilders.

With great variation between the agencies and over the years, performance in the Dutch advertising industry shows a weakly positive picture. The annual income growth of the agencies reaches an average of ower 7 percent. The maximum growth rate observed for a company (in one year) is 225 percent and the minimum is -77 percent. Of course, the largest growth values are accounted for by the smaller agencies, since a small absolute income growth rapidly constitutes a strong percentual growth for these agencies. The average annual staff growth is 3.54 percent, the maximum rate for a company (in one year) reported being 137 percent and the minimum -65 percent. Again, the largest growth figures are achieved by the smaller agencies. The extreme growth values are of course more pronounced at the observation level compared to the aggregate level. At the aggregate level (the average of the time period an agency is included in the sample), the maximum income growth and staff growth are 122 and 52 percent, respectively. The average productivity in the industry is . 16 , with a maximum of .58 and a minimum of .03 . Especially the last few years of the time period, 1991-1994, have been difficuit years for the industry.

It must be noted that since nowadays many agencies are organized in groups, income and staff data are sometimes only provided at the group lewel. The above mentioned absolufe income and employee information always refer to the individual agency level, implying missing values for several agencies and several years. However, the growth values of income and staff size are occasionally based on the absolute group values. When absolute income and staff values were unavailable at the individual level, but were provided at the group level, the group growth was used as a proxy for the individual agency growth. With respect to income growth this occurs for 6 agencies and 49 observations, while for staff growth this involves 6 agencies and 31 observations.

\footnotetext{
In constunt 1985 prices.
} 
Table 2.6. Descriptwes of the sample of Dutch advertising agencies, $1984-1994$

\begin{tabular}{|c|c|c|c|c|c|c|c|}
\hline Varbables & Mensures & Meau: & $\begin{array}{l}\text { Standarid } \\
\text { Deviativern }\end{array}$ & Mruxî̀men & Mintritum & v & Chaptiker \\
\hline 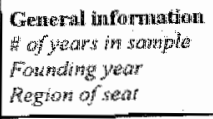 & 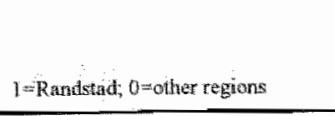 & $\begin{array}{l}7.28 \\
1970.4 \\
.72\end{array}$ & $\begin{array}{l}3.45 \\
20.42 \\
\end{array}$ & $\begin{array}{l}1100 \\
1993 \\
1.00\end{array}$ & $\begin{array}{l}1.007 \\
1807 \\
.00\end{array}$ & $\begin{array}{l}2321 \\
2233 \\
2321 \\
\end{array}$ & $\begin{array}{r}3 ; 5 \\
4 ; 5 \\
\end{array}$ \\
\hline 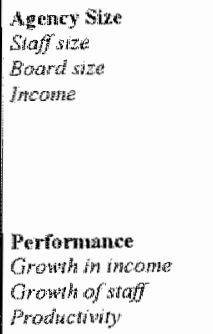 & 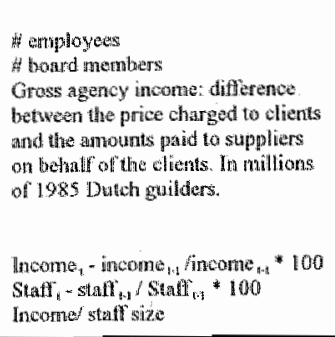 & $\begin{array}{l}7.19 \\
3.54 \\
1.6\end{array}$ & $\begin{array}{l}21.73 \\
19.42 \\
06\end{array}$ & $\begin{array}{l}22.5 .41 \\
137.59 \\
.58\end{array}$ & $\begin{array}{l}-77.17 \\
-65.38 \\
63\end{array}$ & $\begin{array}{l}22711 \\
2011 \\
2303\end{array}$ & $\begin{array}{l}3: 45 \\
3,4: 5 \\
3,4: 5 \\
\\
\\
3,4 ; \\
3,45 \\
3\end{array}$ \\
\hline $\begin{array}{l}\text { Omaersilip } \\
\text { Oninershipg by a large } \\
\text { adhertising firm }\end{array}$ & 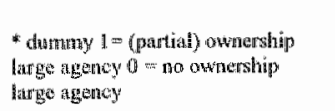 & .22 & - & 1.00 & .00 & 1832 & $3,4: 5$ \\
\hline 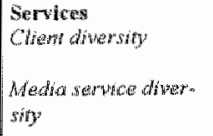 & 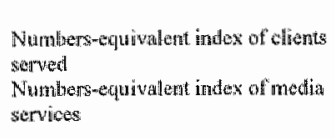 & $\begin{array}{l}4.22 \\
2.19\end{array}$ & .54 & $\begin{array}{l}9.23 \\
3.85\end{array}$ & 1.000 & $\begin{array}{l}96.5 \\
965\end{array}$ & 4 \\
\hline 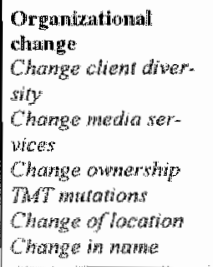 & 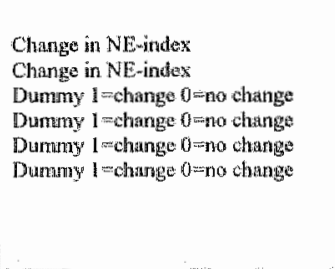 & $\begin{array}{l}009 \\
.04 \\
17 \\
39 \\
01 \\
.04\end{array}$ & $\begin{array}{l}.78 \\
.29 \\
- \\
- \\
-\end{array}$ & $\begin{array}{l}4.93 \\
1.93 \\
1.00 \\
1.00 \\
1.00 \\
1.00\end{array}$ & $\begin{array}{l}-3.66 \\
-1.37 \\
00 \\
00 \\
00 \\
.00\end{array}$ & $\begin{array}{l}965 \\
965 \\
965 \\
965 \\
965 \\
965\end{array}$ & $\begin{array}{l}4 \\
4 \\
4 \\
4 \\
4 \\
4\end{array}$ \\
\hline 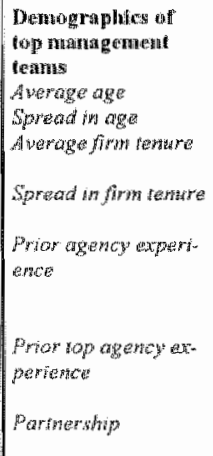 & 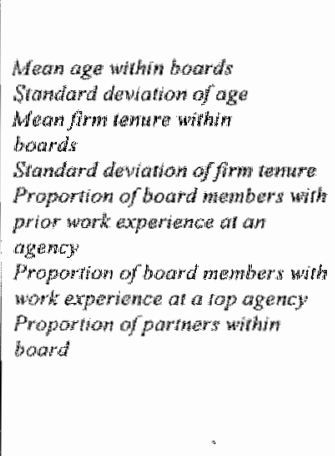 & $\begin{array}{l}43.56 \\
4.18 \\
7.84 \\
2.93 \\
88.78 \\
50.44 \\
74.96\end{array}$ & $\begin{array}{l}4.89 \\
2.86 \\
4.93 \\
3.58 \\
24.81 \\
40.45 \\
40.60\end{array}$ & $\begin{array}{l}62.00 \\
18.38 \\
21.000 \\
14.85 \\
100.00 \\
100.00 \\
100.000\end{array}$ & $\begin{array}{l}31.00 \\
.00 \\
000 \\
60 \\
.00 \\
.00 \\
.00\end{array}$ & $\begin{array}{l}384 \\
384 \\
384 \\
384 \\
384 \\
384 \\
384\end{array}$ & $\begin{array}{l}5 \\
5 \\
5 \\
5 \\
5 \\
5 \\
5\end{array}$ \\
\hline
\end{tabular}




\subsubsection{Ownership and serwices offered}

The vast majority of the advertising agencies is (partly) owned by their board members. 22 percent of the firms in the sample are (partly) owned by a large, mostly multinational, advertising agency. Specifically the larger companies are, at least partly, owned by a multinational agency. These multinational agencies are headquartered in the U.S., the U.K. and France.

The diversity of clients is considerable. With a maximum client diversity (numbers-equivalent index of clients served) of 9.23 , a minimum of 1 and an average of 4.22 , the agencies generally obtain their income from serving several categories of clients. Most agencies generate their income with a diverse media portfolio as well. The average numbers-equivalent index is 2.19 , with a maximum of 3.85 and a minimum of 1 .

The agencies display, on average, only small changes in these strategies. Client diversity is extended, on average, with a value of 09 . Maximum and minimum changes in the client NEindex are 4.93 and -3.66 , respectively. Media service diversity is on average, weakly enlarged (04) Board mutations occur quit often. On average, each year within 39 percent of the firms a top management team change has taken place. Ownership changes are also rather frequent: annually 17 percent of the agencies has experienced a change in ownership. Finally, the majority of agencies refrains from changing their name or location during the 1984-1994 period.

\subsubsection{Top management team characteristics}

The average age of managers within the boards is 44 years, with a maximum and a minimum of 62 and 31 years, respectively. The average firm tenure of members in the boards of advertising agencies is almost eight years, with a maximum of 21 years and a minimum of 0 years (when all top managers have started during the year of observation). On average, 88 percent of the top management team executives has prior agency experience and 50 percent has experience at a top agency. Both extremes, i.e, teams that consist exclusively of (top) agency experienced top managers and those that include only unexperienced managers, appear to coexist. Finally, an average of 75 percent of the top executives owns shares in the agency. Agencies whose top managers own 100 percent and firms with executives owning 0 percent of firm shares are both observed in the sample.

\subsection{The financial performance of advertising agencies}

Before turning to the empirical studies, it is important to reflect on the reliability of the financial performance measures that are examined in these studies (The reliability of the proxy for failure was already addressed in Section 2.5.4). The financial performance of advertising firms

\footnotetext{
The numbers-equivalent index is explained lin Char ter 4 in which it is used. So are the categories of clients ard the exat measures of the medis portiolio.
} 
is measured by fim income (Chapters $3-5$ ), inconve growth (Chapters $3-5$ ) and growth in staff size (Chapter 3). As indicated before, the data on income and staff size are obtained from industry yearbooks (Adformatie Bureaubijlage) which, in turn, receive the information from agencies on a voluntary basis. That is, Adformatie Bijlage sends out questionnaires to advertising firms which the latter voluntarily fill out and send back. While an advertising firm may prefer to expose itself in yearbooks with flattering company figures, it would harm the firms" image substantially if the provided figures would appear to be incorrect. Thus, if it ever occurs that income and staff figures are somewhat positively biased, this would probably only be in extremely small amounts. The general tendency, i.e., an increase or decrease compared to the former year, would still be apparent. The implications of a possible positive bias in the financial performance of firms for the empirical studies carried out in the following chapters are twofold. First, the average financial performance of the advertising agencies in the sample may be bit overestimated. Second, if a positive bias in the financial performance exists, the examined relationships with financial performance as the dependent variable are somewhat underestimated. The linkages that do appear, may therefore be considered as very robust.

In Chapter 6 , which summarizes the conclusions of the empirical studies, the reliability of the performance measures, i.e., the probability of failure and the financial performance indicators, will be addressed again. Attention is paid to the consistency in the findings over the chapters and over the performance indicators. 


\section{CHAPTER 3}

\section{ENTRY, EXIT AND PERFORMANCE}

\subsection{Introduction}

The dynamics of entry into and exit from markets is an important research domain in the field of industrial organization. The size and magnitude of entry and exit cohorts affect industry evolution and, conwersely, market characteristics have an important impact on entry and exit flows. In recent years entry and exit have received considerable attention in the literature, with various aspects of the phenomena being addressed. The determinants of entry and exit flows have been analyzed in a number of countries and across numerous industries (see Cable and Schwalbach, 1991). However, only few authors have addressed the issue in-depth by focusing on particular industries (see, e.g., Joskow, Werden and Johnson, 1994, and Sutton, 1991, for exceptions). Additionally, the studies are generally conducted in manufacturing industries, leaving service industries virtually unexplored in this respect. 'Only a few case studies and no cross-sectional analyses of entry look beyond manufacturing. They are limited to banking, food retailing, air transport, and medical services" (Siegfried and Evans, 1994: 123). The studies on the entry and exit process point out that (i) entry and exit flows are substantial in most countries and industries (Gieroski, 1995), (ii) entry and exit are generally related (Siegfried and Evans, 1994; Geroski, 1991 and 1995), (iii) entrants and exiters are relatively small (Geroski, 1995) and (iv) onlly few entrants survive for a long time or prosper during their short lives (Geroski, 1991).

Recently, a wave of studies has focused on the performance of firms after entry ( Thurik and Audretsch, 1996). This is important since, as most entrants are small, the danger for incumbents principally resides in the post-entry performance of new firms. Studies on this topic have typically linked the probability of firm survival and growth to age and size (Thurik and Audretsch, 1996). In general, results point out that survival chances increase with age and size, while growth declines with age and size. The key difficulty of studying the performance of firms subsequent to entry is the availability of longitudinal data bases (Audretsch and Mahmood, 1994). While the first studies in this domain were based on fiveyear interval observations (e.g., Dunne, Roberts and Samuelson, 1988), the most recent studies generally include annual observations or else biennial observations. In general, this research stream also involves large numbers of countries and industries, again preferring the manufacturing sector above the service sector. However, due to differences between the two 
sectors, the dynamic process of entry and exit in service industries may vary from the process observed in manufacturing industries. Relewant in this respect is the finding by Troske (1993) and Pakes and Ericson (1989) that service firms generally employ lewer people and invest less in capital. Moreover; a comparison between entry and exit phenomena in manufacturing and service industries (finance, insurance and real estate) by Troske (1993) indeed revealed substantiall differences in entrants' and exiters' behavior across the two sectors. Finally, studies pertainimg to post-entry performance mostly involve cohorts of entrants which are followed several years after entry. Analyses comprising a comparison of the performance of newcomers relative to incumbents are scarce (see, e.g, Mata, 1994, and Mata et al, 1995, for exceptions). Nevertheless, it is at least as informative to compare entrants" performance with the performance of incumbents, instead of in isolation.

While the development of firms subsequent to entry has now been studied rather elaboratively, the dynamic process of exit, i.e., the performance of firms in the years prior to exit, has received scarce attention in the industrial organization literature. Nevertheless, incumbents as well as the overall market performance are as much affected by the exit of firms as by the entry of companies. The performance of firms in the years preceding exit has been tracked by Troske (1993) who shows that failing firms already start showing signs of weakness a number of years before exit. Furthermore, Troske reports differences in the exit process between service and manufacturing industries.

Only a few studies in the post-entry performance literature have distinguished between various exit modes (Dunne and Hughes, 1994; Baldwin and Gorecki, 1991). The analyses have, however, been limited to the relationship between firm size and exit mode (Dume and Hughes, 1994) and to the connection between failure rates and reason for exit (Baldwin and Gorecki, 1991). Mode of exit has not yet been related to the pre-exit performance patterns of firms and can prove to be of special interest.

The aim of this chapter is to extend the empirical Viterature on the post-entry performance and pre-exit performance of firms by examining the two processes in conjunction, and by distinguishing between various modes of exit in the latter analysis. The performance of firms in the years following entry is examined by analyzing the effects of age on failure, growth, size and productivity. Entrants are followed up to nine years subsequent to entry. and their performance in the post-entry years is compared with the performance of incumbent firms. The dynamic exit process is investigated by studying the influence of size, growth and productivity on three mades of failure. First, the performance of failing firms is traced until nine years prior to exit and compared to the performance of surviving firms. Second, in order to control for age and size effects, the pre-exit performance of failing 
firms is compared to the performance of matched survivors, i.e, a matched pair analysis is carried out. The study is conducted in a specific service industry" the Dutch industry of advertising agencies; over a time period of eleven years, 1984-1994, using annual data. Finally, while prior studies made use of either employee data or output figures, the present study has the availability of both size measures.

This chapter thus reflects upon and adds to the current state of art in the field of industrial organization only. This is not to say that in other branches of organization sciences nothing has been produced that may complement what will be introduced below. To the contrary, particularly the literature in the domains of organizational ecology and strategic management witnesses a large number of studies that are relevant in this context. For this, the reader is referred to Chapters 4 and 5 (cf. Van Witteloostuijn, 1996; Boone and Van Witteloostuijn, 1996). For the sake of clarity of focus, this chapter is restricted to Industrial Organization, however. This explains the poor theory guiding the analyses and the mainly descriptive nature of the proposed statistics. The present chapter does not pay much attention to the explaining variables of success or failure. As far as it is concerned with explaining antecedents, only variables traditionally used in Industrial Organization research in this context are introduced. This concerns the variables (start-up) size, (ownership,) growth rate and productivity. Remaining variables that are often examined in this stream of Industrial Organization research - such as market growth, concentration and capital intensity - are not investigated explicitly, but are controlled for in the matched-pair design analysis. Chapters 4 and 5 examine the influence of other explaining variables.

The chapter is organized as follows. The next section discusses theory and prior research findings on the topic, and proposes several hypotheses. In the third section, the methods are described. Section 3.4 concerns the entry and exit process in the Dutch industry of advertising agencies during the time period. Section 3.5 presents a comparison between the postentry performance of new establishments and incumbent firms. In Section 3.6 the pre-exit performance of failing firms is compared to the performance of surviving companies. The chapter ends with a discussion and some concluding remarks in Section 3.7 and 3.8, respectively.

\subsection{Theory, prior research and hypotheses}

This section provides a summary of the pioneering entry model of Jovanovic (1982) and of results obtained by studies examining the post-entry performance of new firms and the pre-exit performance of failing firms, as carried out in the field of industrial organization. In addition, hypotheses are formulated, based on the results of this earlier work and on the model of 


\section{Jovanovic (1982)}

Jowanovic (1982) proposes a model of "noisy' selection occurring in industries which explains the evolution of industries. Jovanovic argues that firms entering an industry are principally small and have more or less explicit expectations about their efficiency level. During the first years of their lives new firms gradually learn about their real efficiency level. Those firms that reveal to be relatively efficient prosper and expand, while firms that learn that they are relatively inefficient shrink and eventually leave the market. Failure rates should then decrease with age and also with size, as firms gain more insight into their cost and efficiency levels. Furthermore, younger firms are assumed to grow faster than their older counterparts and the "variability of growth rates will be largest among the young (and therefore smaller) firms' (Jovanovic, 1982: 655). The model further suggests that post-entry performance differences are caused by differences between entrants, such as differences in entry costs, fixed costs or expectancies concerning variable costs. For instance, firms that have relatively high fixed costs have a higher probability of exit. Fims that expect to be relatively efficient, will enter at a relatively large size.

Table 3.1 supplies, in alphabetical order, a review of 18 representative studies on the subject. Many of the studies test the propositions of the theory of Jovanovic (1982). Table 3. I is therefore organized more or less concordingly. Age and survival are linked to size, growth and productivity. The conclusions drawn below on the post-entry and pre-exit performance of firms are based on the results of the studies summarized in Table 3.1 and Geroski (1995). The first part of the summary of the results concentrates on the post-entry performance of new establishments, discussing the relationship of age with subsequently failure, market shares, size, growth and productivity. The second part focuses on the performance of firms prior to exit. This part summarizes results on the relationslaip of faiture with size, growth and productivity.

\subsection{Post-entry perforwance}

Recent empirical studies on the post-entry performance of new establishments are carried out in the U.S., Canada, the U.K, Germany, Portugal and Chile. All but one (Troske, 1993) of the studies in Table 3.1 are conducted in the manufacturing sector. The studies typically include a large number of industries and a large number of firms. For instance, Dunne, Roberts and Samuelson (1988) examine the entry patterns in 387 U.S. manufacturing industries and Audretsch's study (1991) includes 295 industries. The largest sample of entrants investigated in the post-entry performance literature consisted of a total of over 200,000 firms (Dumne, Roberts and Samuelson, 1989a). Apart from this exceptionally large sample, data sets often comprise around 10,000 entrants. Most studies cover a time period of about ten years. The maximum number of years covered in this stream of research is twenty years (Dunne, Roberts and Samueison, 1988; 1989a \& 1989b) and the shortest time period is five years (Doms et al... 


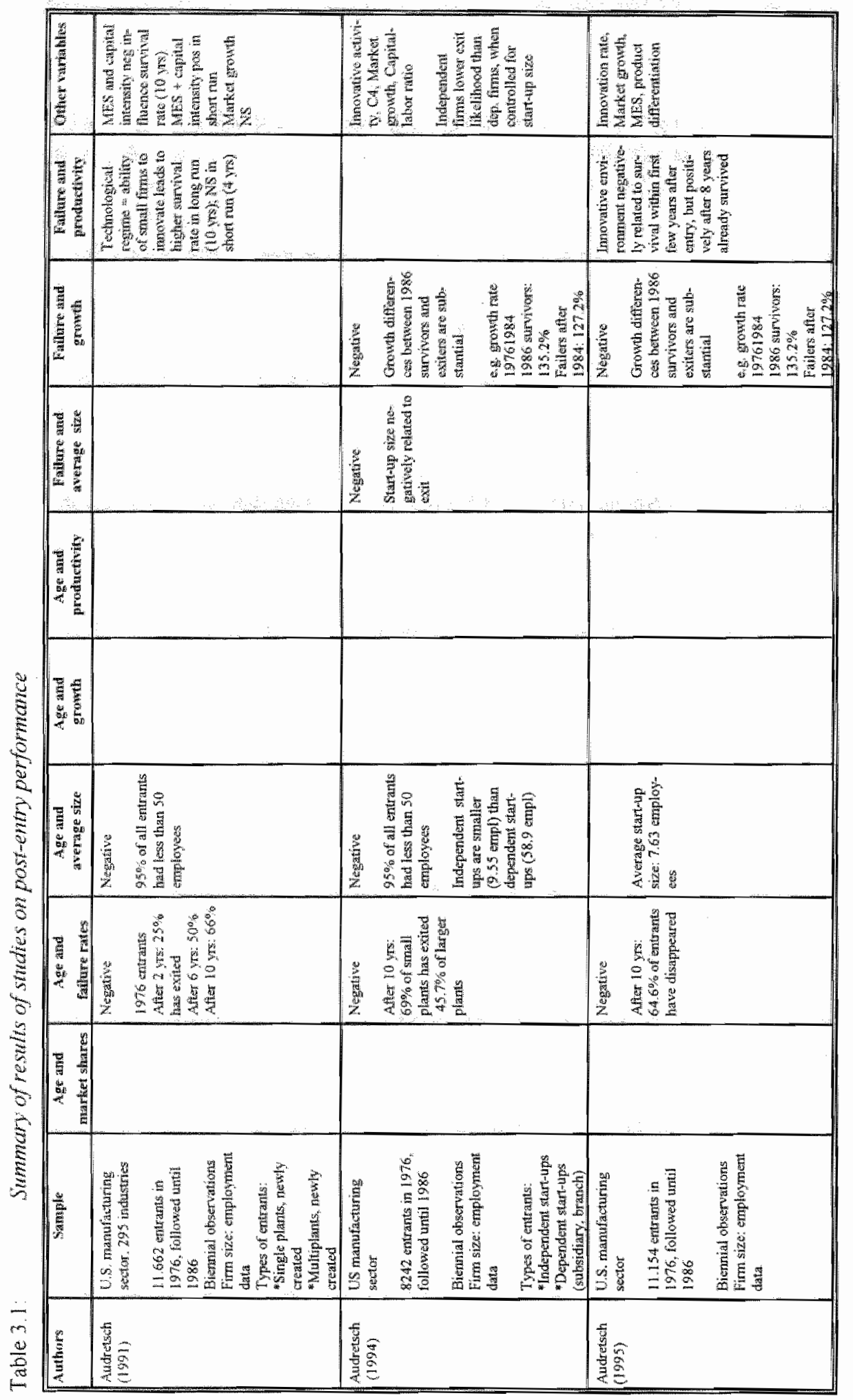




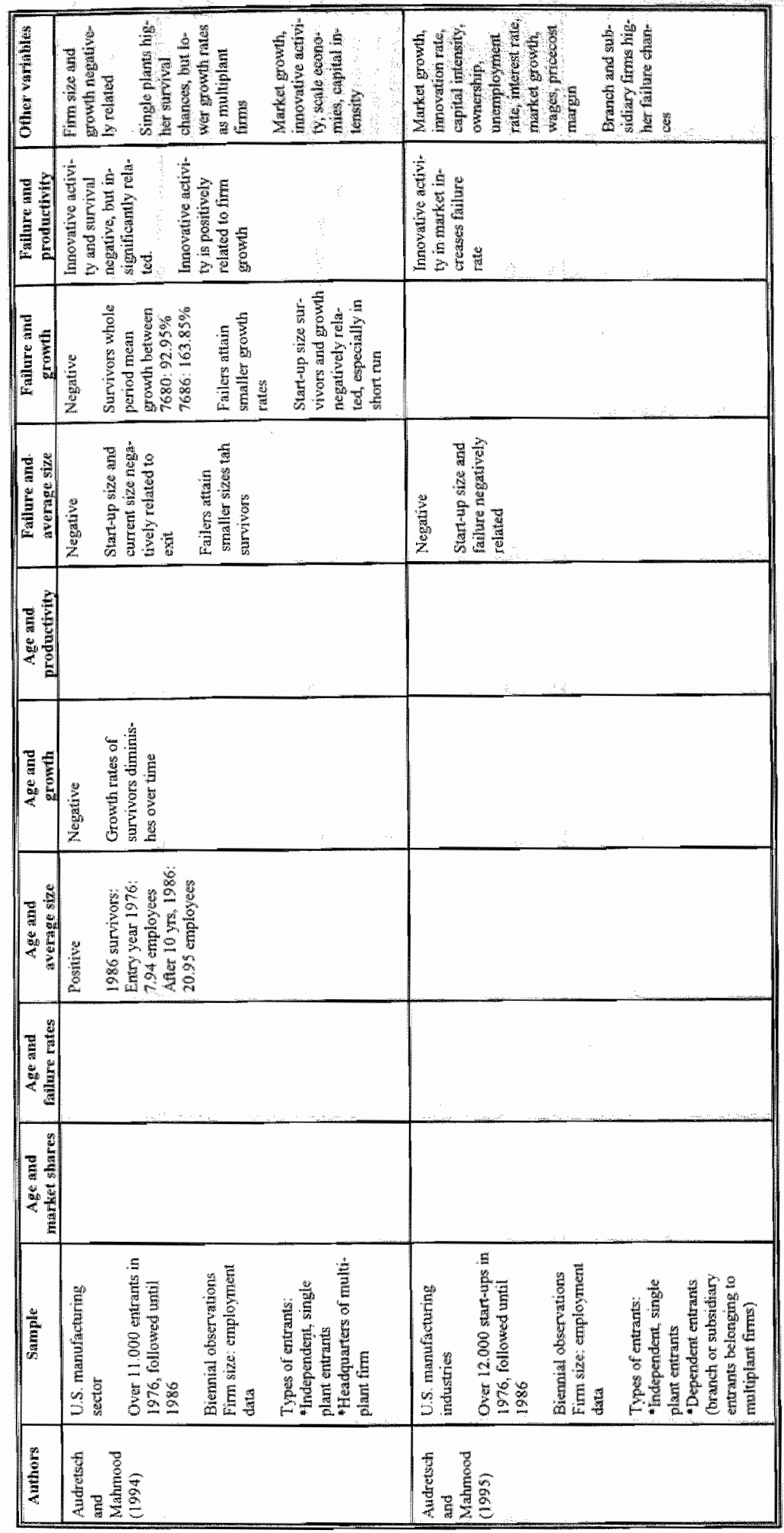




\begin{tabular}{|c|c|c|}
\hline$\frac{5}{5}$ & & 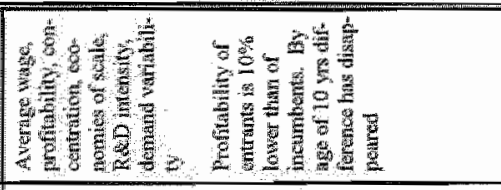 \\
\hline & & 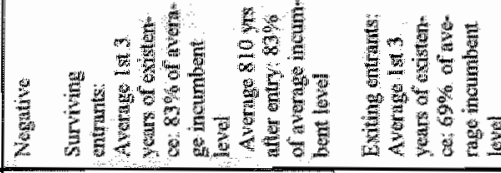 \\
\hline & & \\
\hline 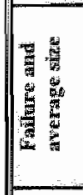 & & 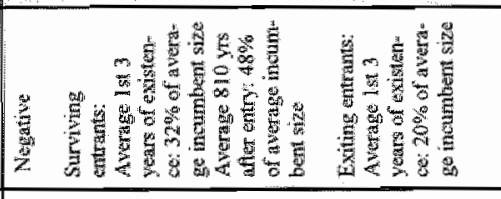 \\
\hline 意 & & 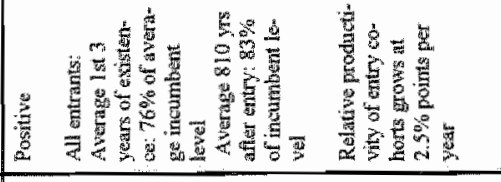 \\
\hline 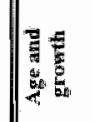 & & \\
\hline 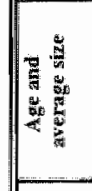 & & 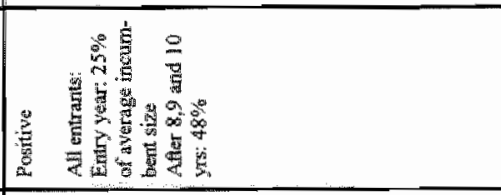 \\
\hline 䇾 & 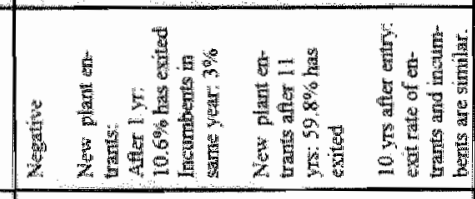 & 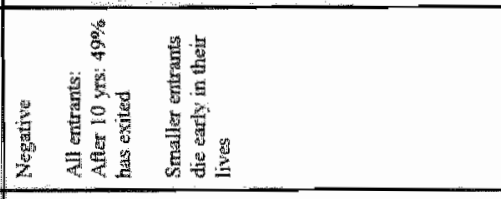 \\
\hline 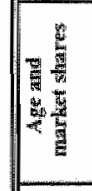 & 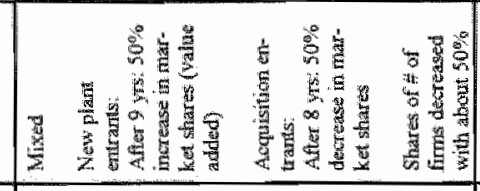 & 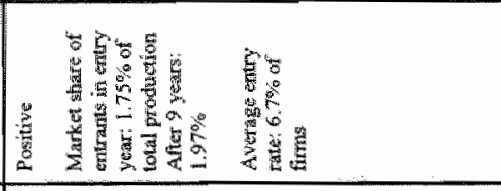 \\
\hline $\mid$ & 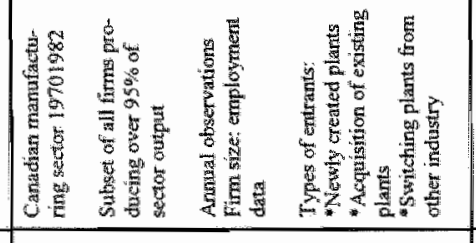 & 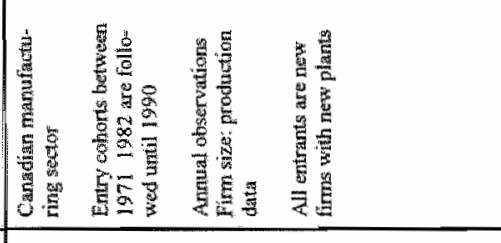 \\
\hline$\frac{2}{2}$ & 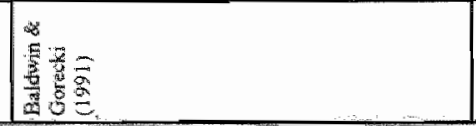 & 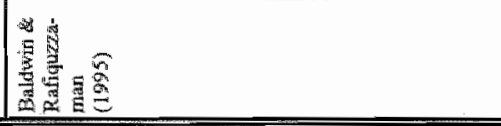 \\
\hline
\end{tabular}




\begin{tabular}{|c|c|c|}
\hline$\frac{z}{2}$ & 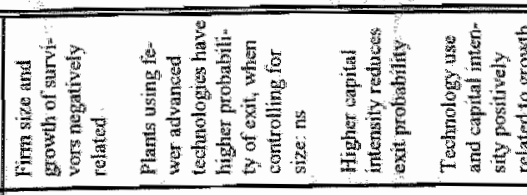 & 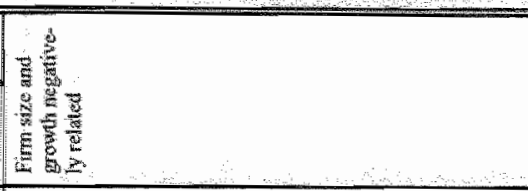 \\
\hline$\frac{2}{2}$ & 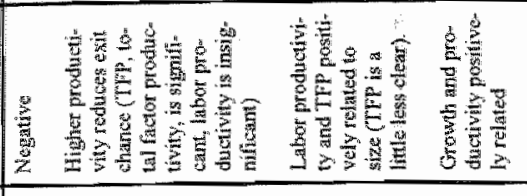 & \\
\hline 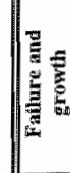 & & 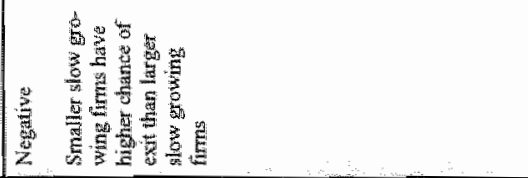 \\
\hline 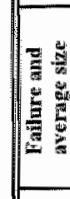 & 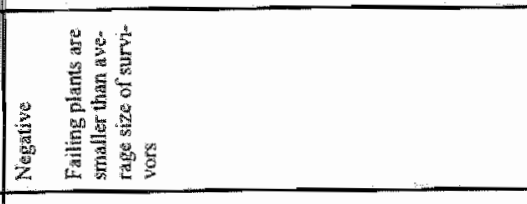 & 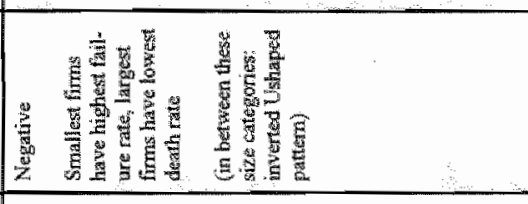 \\
\hline 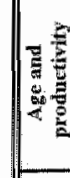 & 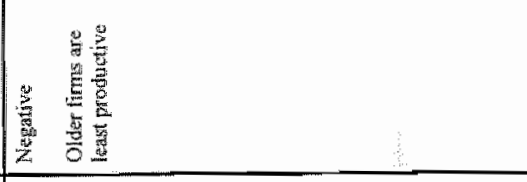 & \\
\hline 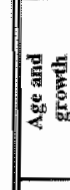 & 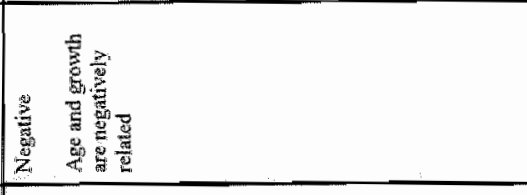 & 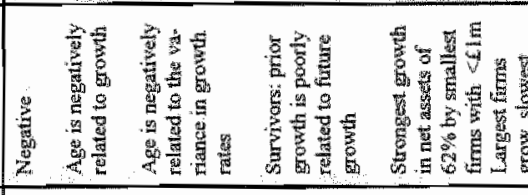 \\
\hline 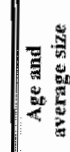 & & \\
\hline 要 & 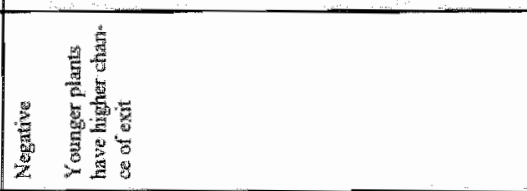 & 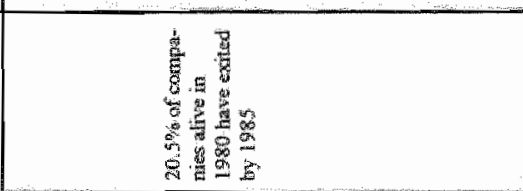 \\
\hline 量 & & \\
\hline 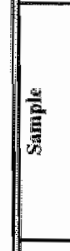 & 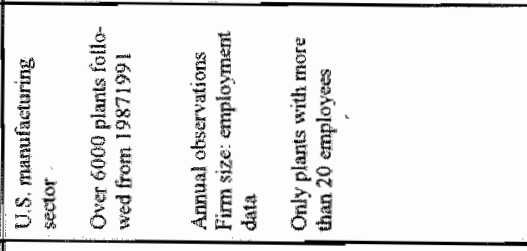 & 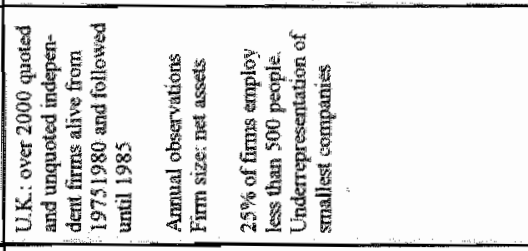 \\
\hline 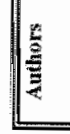 & 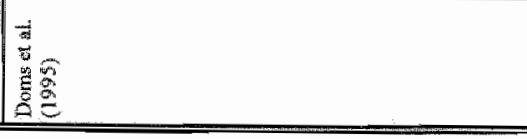 & 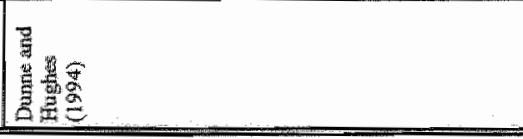 \\
\hline
\end{tabular}




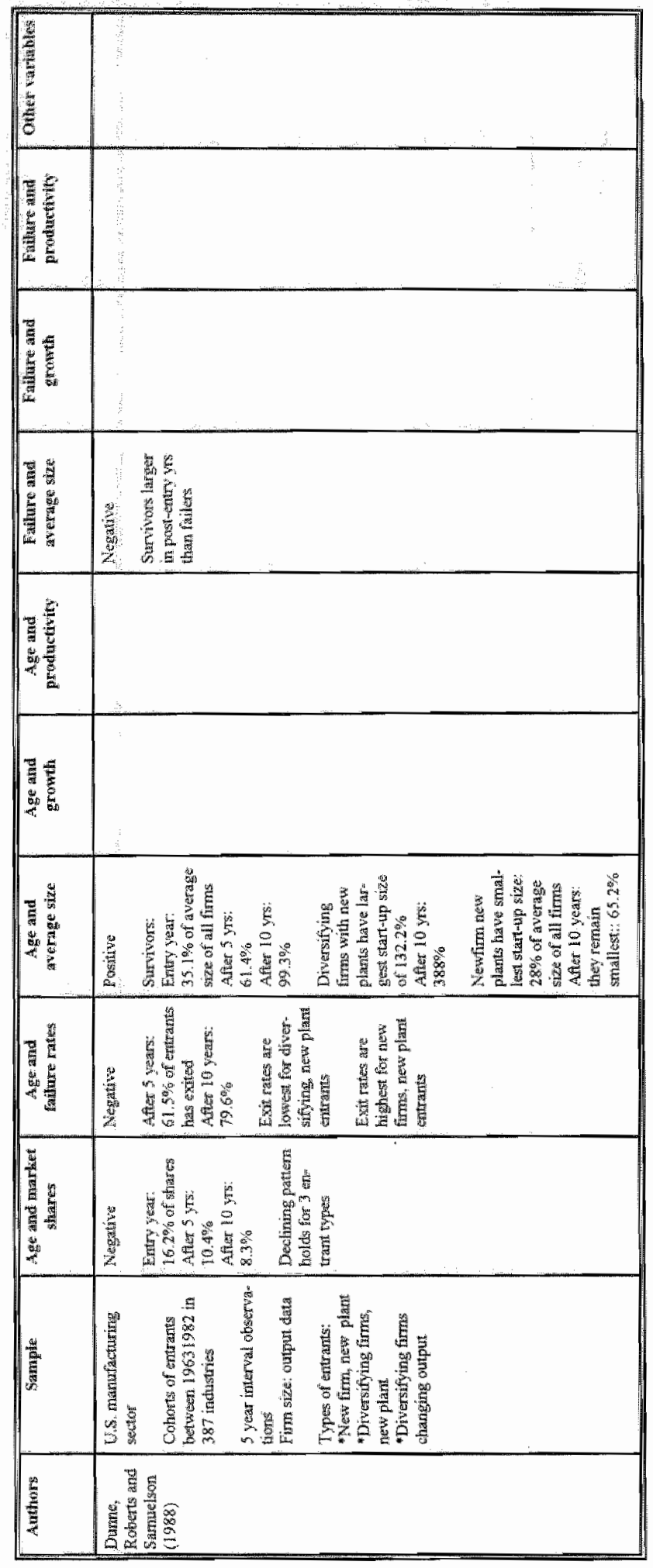




\begin{tabular}{|c|c|c|}
\hline & 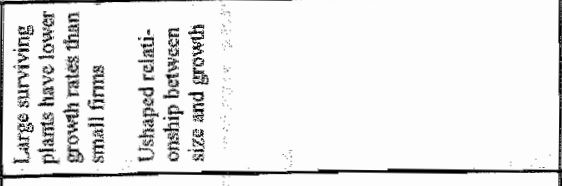 & 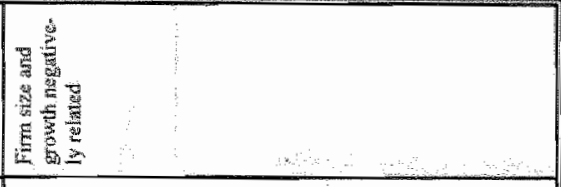 \\
\hline & & \\
\hline$\underline{m}$ & & \\
\hline & 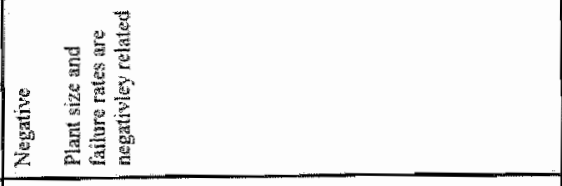 & 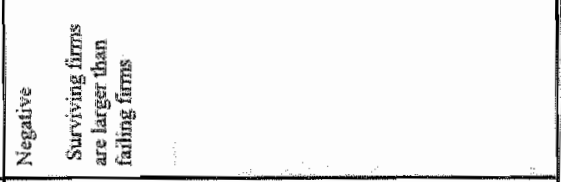 \\
\hline & & \\
\hline & 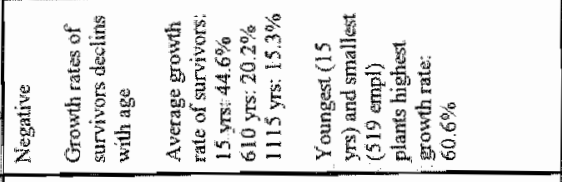 & 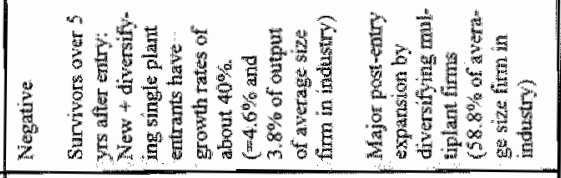 \\
\hline & & 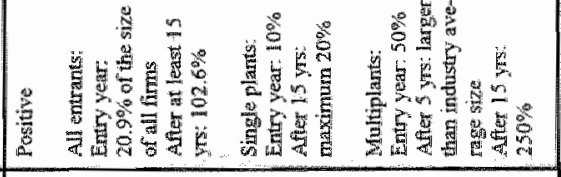 \\
\hline 凅 & 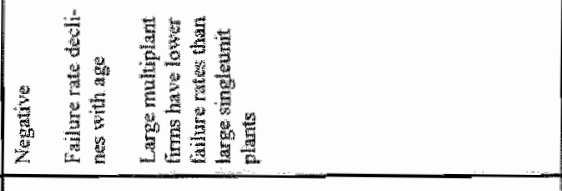 & 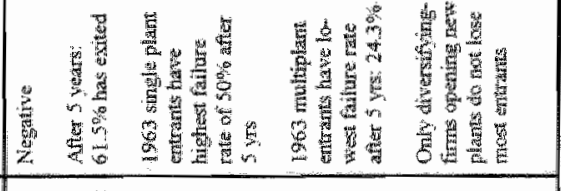 \\
\hline 量 & & 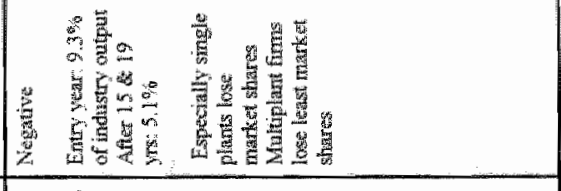 \\
\hline 信 & 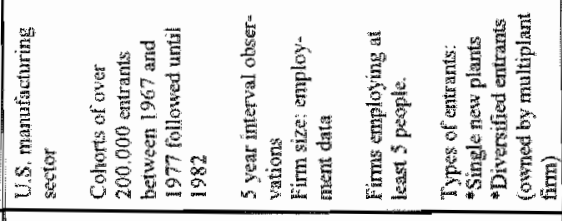 & 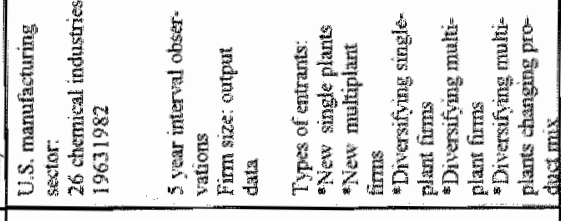 \\
\hline & 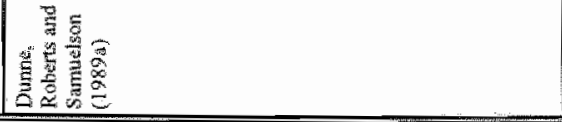 & 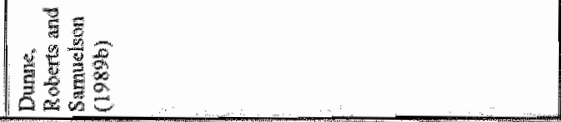 \\
\hline
\end{tabular}




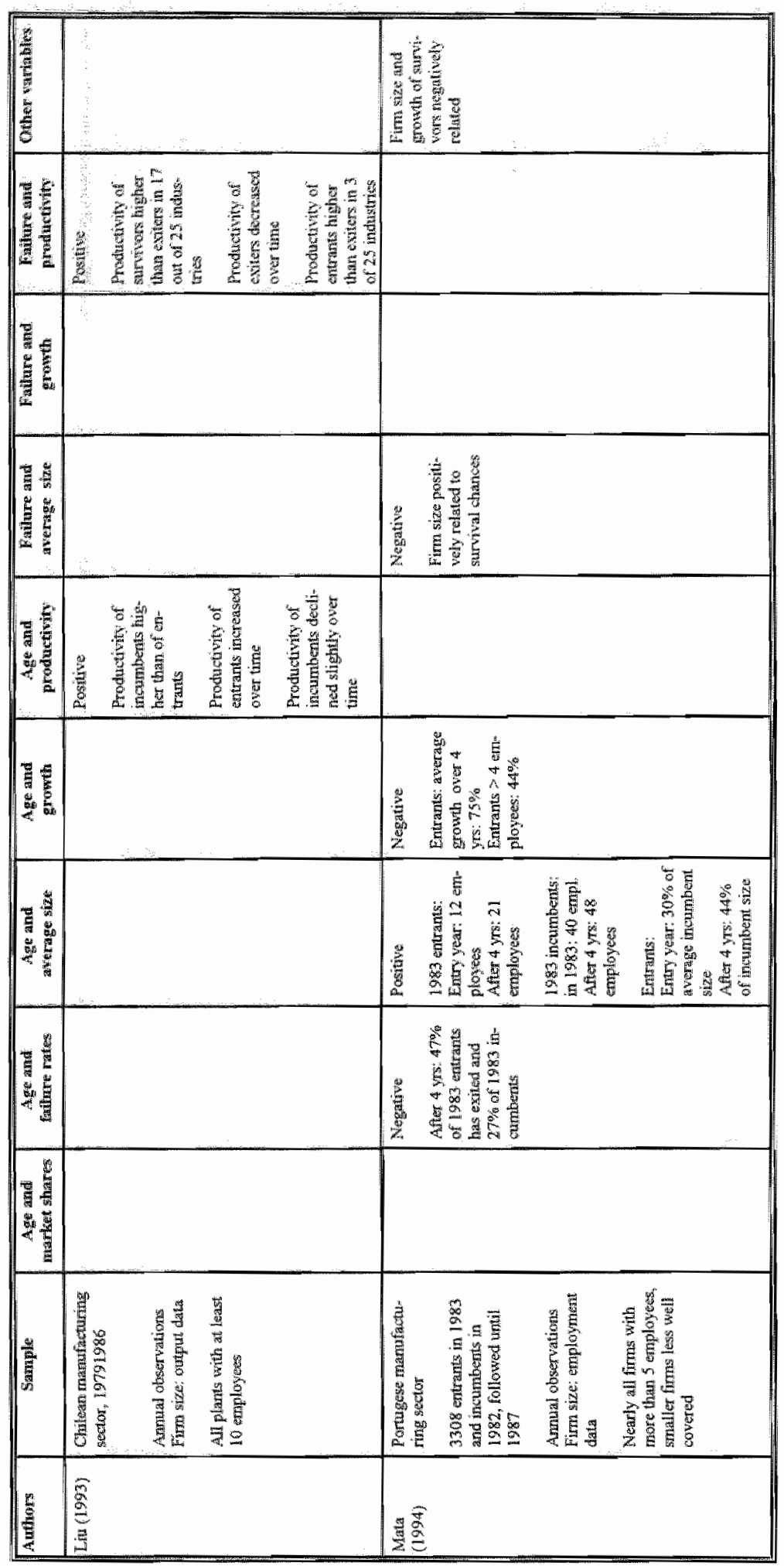




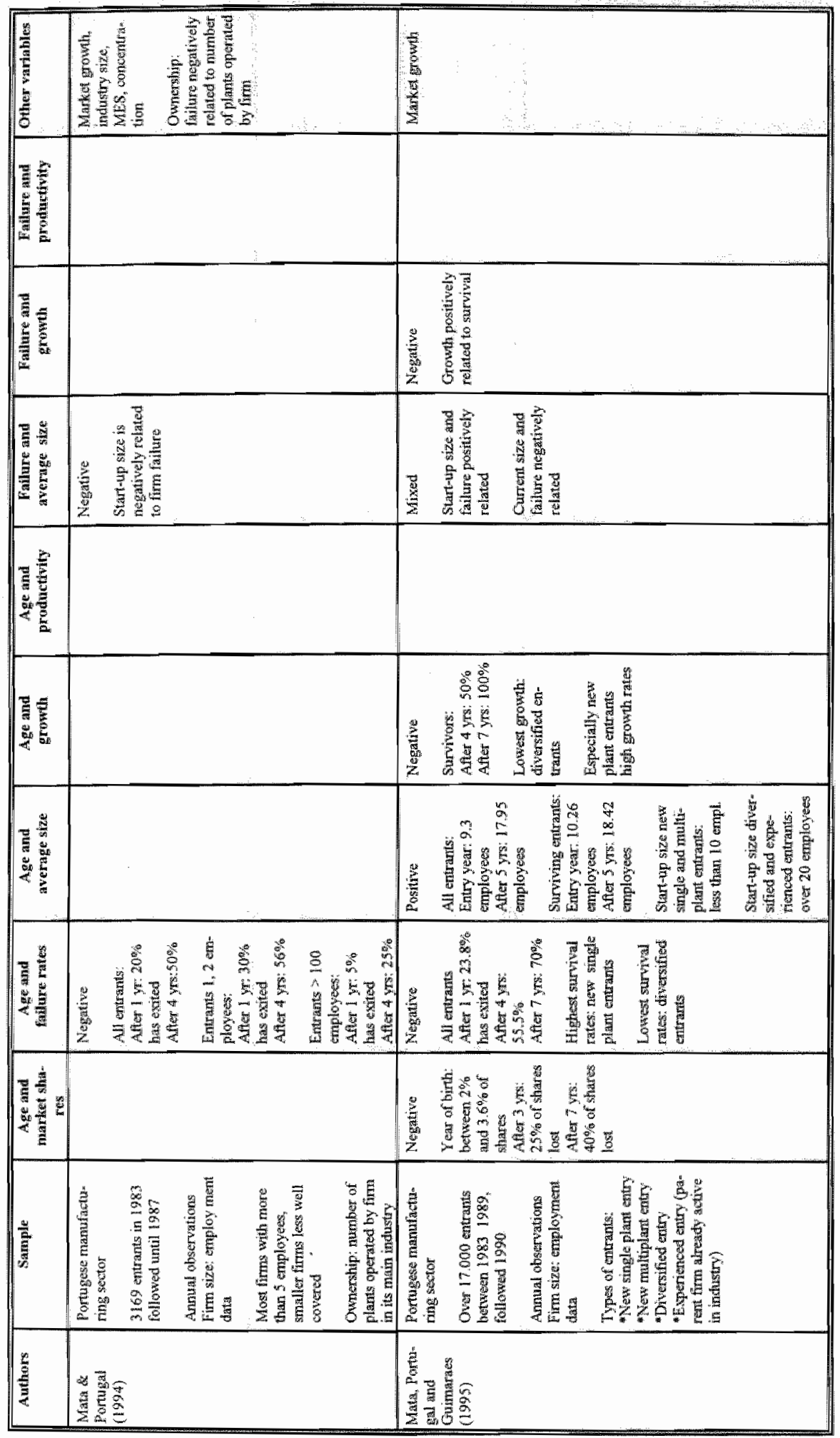




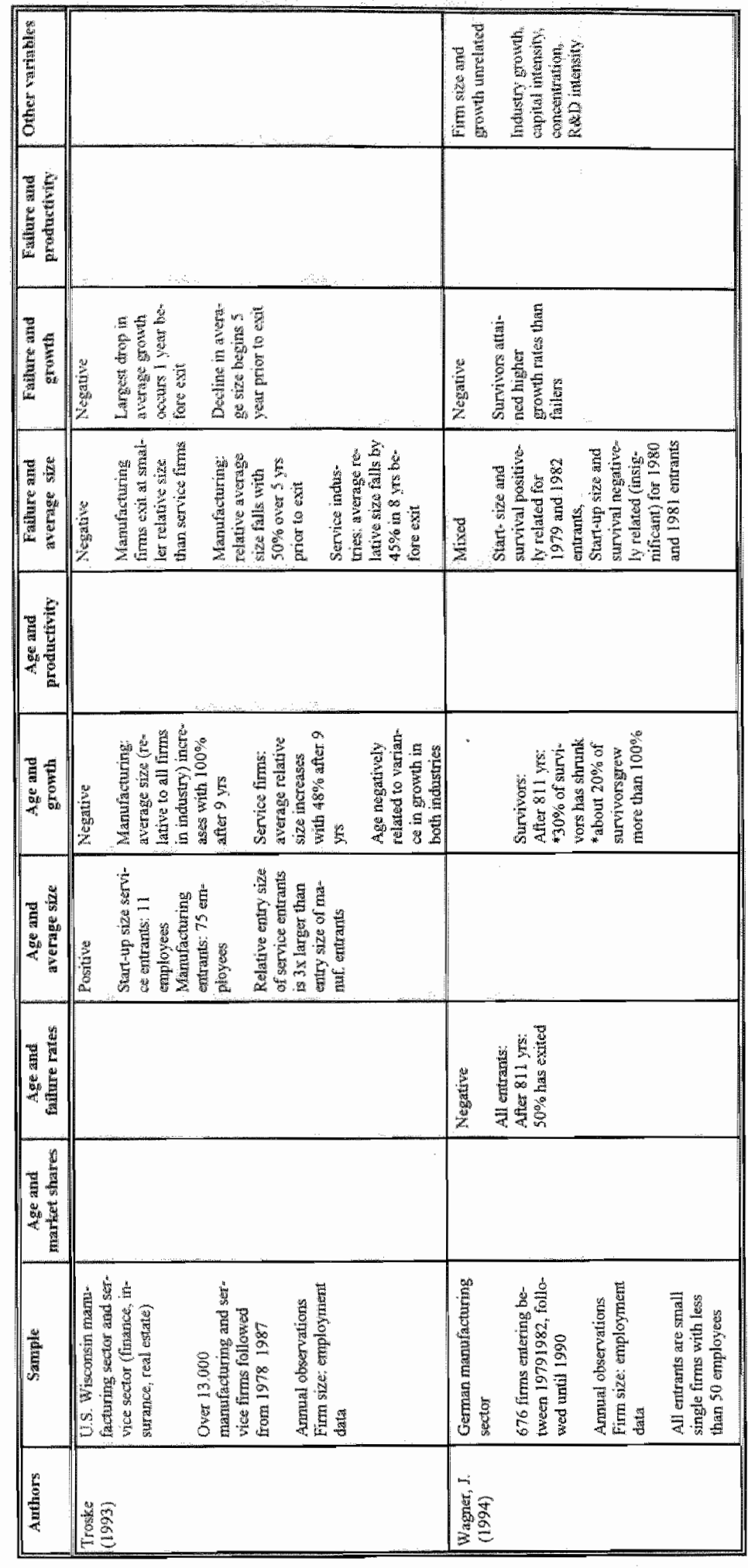


1995). However, while the total time period examined differs between the studies, so does the time period between the observations. Either annul, biennial or five-year interval observations are used. The observation period is generally positively related to the total time period covered by the study. Thus, while the study by Dunne, Roberts and Samuelson (1988; 1989a\& 19896) covers a twenty-year period, observations are included only at five-year interwals. Studies covering five or seven years use anmual observations (Doms et al, 1995; Mata, 1994; Mata and Portugal, 1994; Mata, Portugal and Guimarães, 1995), and those examining about ten years of the lives of entrants use either annual (Baldwin and Gorecki, 1991; Baldwin and Rafiquzzaman, 1995, Dunne and Hughes, 1994, Liu, 1993, Wagner, 1994) or biennial (Audretsch, 1991; 1994 \& 1995; Audretsch and Mahmood, 1994 \& 1995) observations.

Many studies distinguish between various types of entrants. The most general distinction is between single, independent entrants and dependent or diversifying entrants (subsidiaries or branches). Most entrants into industries appear to be single, newly created establishments. For instance, Dunne, Roberts and Samuelson (1988) found that 55.4 percent of all start-ups were single, independent firms, while diversifying new plant entrants accounted for 8.5 percent of all start-ups and 36.1 percent were diversifying firms changing their product mix in existing plants.

\subsubsection{Age and failure rates}

Failure rates of new established firms appear to be substantial on average, but to vary widely across industries. Consistent with Jovanovic (1982), most studies find a negative relationship between firm age and faillure rates. The probability of exit tends to decrease as firms age. The failure rates appear to be highest in the first years following entry and to decline monotonically afterwards. With quite some differences between the studies, after one and two years subsequent to entry, about 20 percent of new establishments have failed. The failure percentage increases to around 50 percent after five years and to more than 60 percent ten years following entry.

Few studies compare the failure rates of entrants with those of incumbents. Results point to substantially lower failure rates of incumbents compared to entrants. Mata (1994), for instance, found that four years after entry 47 percent of the entrants had disappeared, while only 27 percent of incumbents had failed in the same period. Only ten years following entry the exit rates of entrants attain those of incumbents (Baldwin and Gorecki, 1991).

Based on earlier work and theory, in the Dutch advertising industry, a negative relationship is expected between age and failure. 


\subsubsection{Age and market shares}

The market shares of entry cohorts (in the year of entry), and the way they are measured, vary actoss the studies, from 1.75 percent of total production (Baldwin and Rafiquzzaman, 1995) to 16 percent of total output (Dunne, Roberts and Samuelson, 1988). Most studies report a subsequent decline in market shares, with a loss of about 25 percent, around four years after entry. While the declining pattern holds for the various entrant types, especially single plants appear to lose market shares in the years following entry. Consistent with these findings it is bypothesized that market shares of Dutch advertising agency entry cohorts decline as they age.

$\mathrm{H}_{2}$

$$
\text { Market shares of entry cohorts decline with age. }
$$

\subsubsection{Age and firm size}

The size of entering firms is most frequently measured by the number of people employed. However, several studies take the output (Dunne et all. 1988 \& 1989b; Liu, 1993), production (Baldwin and Rafiquzzamann, 1995) or net assets (Dunne and Hughes, 1994) of firms to indicate their size. The size of entrants is expressed either in absolute terms (the absolute number of people employed), as a percentage of the average incumbent size or as a percentage of the average size of all firms in the industry.

Consistent with the model of Jovanovic, the research findings indicate that , both in manufacturing and service industries, the average entrant is rather small. New established firms. employ between 7 and 12 persons at the time of entry, which concordes with an average size of around 20 to 35 percent of the average size of incumbents or all firms. Interestingly, Troske (1993) reports that the relotive start-up size of service entrants was three times as large as the average relative start-up size of new established manufacturing firms. Service industries, apparently, mainly consist of rather small firms, while manufacturing industries are populated with relatively large companies.

As predicted by Jovanovic (1982), differences in the start-up size between the various types of entrants are substantial. Single plant firms are the smallest new born firms and diversified entrants are generally the largest entrant type. Dunne, Roberts and Samuelson (1989b), for instance, report an average start-up size of single plant firms of about 10 percent of the size of all firms and an initial average size of over 50 percent of the size of all firms for multiplan entrants. Similarly, Mata, Portugal and Guimarães (1995) observe an average start-up size of less than 10 employees for single plant entrants and more than 20 people for diversified entrants. Diversifying firms may enter at a larger size since their experience in other industries allows them to enter at a lower cost, to have lower expected variable cost levels and to have

\footnotetext{
1 Troske (1993) refers here to the size of entrants relative to all firms in the industry
} 
better estimates of the expected costs in the new industry than single new firms (Dunne; Roberts and Samuelson, 1989b). In the Dutch advertising industry, it is also expected that most entrants are independent agencies which are smaller compared to their dependert, or diversifying, entering counterparts.

Independent entrants are smaller in size than dependent entering firms.

In the years subsequent to entry, the average size of newcomers increases considerably. In terms of the pencentage of the average size of all firms, the average entrant grows; on average, to about half the size of incumbents after 8-10 years (Baldwin and Rafiquzzaman, 1995) and 103 percent of the average size of all firms after at least 15 years (Dunne, Roberts and Samuelson, 1989b). Again, large differences between the various types of entrants exist. Single plants remain smallest and hardly ever attain the average size of all entrants ten years after entry. Diversified (dependent) entrants become largest, and may reach more than three times the average size of all firms, ten years after entry. Also in the Dutch advertising market, it is expected that firm size and age are positively related.

Firm age and size are positively related.

\subsubsection{Age and firm growth}

From the model of Jovanovic (1982) the prediction arises that growth rates are negatively associated to firm age. Empirical evidence indeed indicates that both in manufacturing and service industries entrants grow fastest in the first few years following entry and more slowly afterwards. Mata (1994) examined the growth of entrants and incumbents, and observed that over four years entrants had grown on average 75 percent in size, while incumbents had grown only 20 percent. A negatiwe association between age and growth is, however, not reproduced in all industries. Evans (1987) reports that the negative relationship between age and growth holds within 76 percent of the manufacturing industries included in his study. The connection between age and growth appears to be robust when controlling for size. Dunne and Hughes (1994), for instance, report that a negative relationship holds within each of the three size classes they distinguish. Growth rates obtained by entrants in manufacturing industries appear to be higher than growth rates observed for entrants in service industries. In manufacturing industries, with some variation across studies, a growth of around 100 percent, seven to ten years subsequent to entry, is quite common. In service industries an average growth in size (relative to all firms in the industry) of 48 percent was reported nine years after entry (Troske, 1993).

Since most recent empirical studies have established a negative relationship between frrm 
age and growth, and because this is also predicted by theory, in the Dutch advertising industry a negative relationship is expected, too.

Firm age and growth are negatively related.

\subsubsection{Age and productivity}

If firms enter into an industry with expectations about their efficiency level (Jovanovic, 1982), many fims may begin with misplaced optimism about their survival chances. At the time of entry the average productivity level of newcomers may, thus, be below the productivity level of incumbents. The selection process implies that the most efficient entrants remain alive and increase their efficiency level even further, while the least efficient firms are shaken out of the industry. As time passes, the gap between the productivity level of incumbents and entrants should then narrow:

Several studies indicate indeed that at the time of entry new borns have a lower productivity level than incumbent firms, and that their productivity increases over time. Baldwin and Rafiquzzaman (1995), for instance, report a productivity level of 76 percent of the level of incumbents in the year of entry, increasing to 83 percent after 8-10 years subsequent to entry. Liu (1993) found similar results for Chile. However, Doms et al. (1995) observe a negative relationship between age and productivity. Older firms appear to be the least productive in their sample. In service industries, this relationship has not yet been investigated. There is, however, no apparent reason to suspect a different outcome as the positive association observed in manufacturing industries. A positive association between productivity and age is, thus, expected in the Dutch advertising market.

Firm age and productivity are positively related.

\subsubsection{Sizi, growth and productivity}

The analysis of the post-entry performance of firms focuses on the effect of age on size, growth, market shares, productivity and failure. However, many studies on the topic involve both age and size as independent variables and point out that size is also an important predictor of performance. Size should, therefore, also be taken along in this study. The association between size and age is directly tested with Hypothesis 2, and the effect of size on failure is directly captured with Hypothesis 9 (in Section 3.6 on pre-exit performance). Two additional hypotheses are formulated with respect to the influence of size on growth and productivity. The connection between size and growth has been extensively investigated in the post-entry performance literature, and the empirical evidence indicates that growth declines with size (see, e.g. Evans, 1987; Hall, 1987; Mata, 1994; Dunne and Hughes, 1994). The relationship be- 
tween size and productivity has received less attention in the literature. Outcomes point to a positive relationship, ie, productivity increases with size (Doms et al., 1995). In the Dutch advertising industry the same associations are expected.

H7 Firm size is negatively related to firm growth:

H8 Firm size is positively connected to productivity.

\subsubsection{Pre-exit performance}

According to the theory of Jovanovic failure is negatively related to age, size, growth and productivity. Studies in the post-entry performance literature either relate the propensity of falure to a number of variables using multivariate testing techniques and/or compare the postentry performance of surviving entrants with the performance of failing entrants. In the latter studies, the average performance of new established firms surviving the whole period under study is compared to the performance of new borns failing after a number of years. One study (Troske, 1993) explicitly tracks the performance of failing and surviving firms during the preexit years. The results of the three approaches are, when relevant, summarized below.

\subsubsection{Failure and firm size}

In general, results of empirical studies examining the propensity of failure of new established firms support the assumptions of Jovanovic (1982) and confirm the results of earlier work by Hall (1987) and Evans (1987): namely, a negative relationship between firm size and failure. Exit tends to decrease as size increases. Empirical studies investigating the failure rates of entrants concentrate on the effect of start-up size (instead of current size) and report that smaller entrants show the largest failure rates, while the largest entrants exhibit the lowest exit rates. Only Wagner (1994) does not find a clear relationship between start-up size and the probability of farlure, whereas Mata, Portugal and Guimarães (1995) find a positive relationship between start-up size and failure.

Outcomes of empirical studies comparing the characteristics of falling entrants with those of surviving entrants also reveal a smaller start-up size of failing entrants compared to their surviving counterparts. Baldwin and Rafiquzzaman (1995), for instance, found a difference of 12 percent of incumbent size between failers and surviwors. While surviving entrants started at 32 percent of the average size of incumbents, failing entrants had an initial size of 20 percent of incumbents. A comparison between the hazard rates of incumbents (older firms) and entrants (young firms) by Mata (1994) also revealed that both among incumbents and among entrants the hazard rates were consistently higher for smaller than for larger firms. Few studies explicitIy relate the current size of firms to failure rates. An exception is Mata, Pontugal and Guimarães (1995) who found a negative association between current size and failure of firms. 
In the Dutch advertising indusity, a negative relationship is expected between current firm size and fallure.

Failure rates also appear to differ between various types of entrants. In general, independent entrants are found to exhibut larger exit rates than diversifying newly established firms. Of course, this is closely related to the smaller start-up size of independent firms compared to dependent firms. Independent advertising entrants are, therefore, predicted to show higher failure rates than diversified adventising entrants.

HS

Current firm size and failure are negatively related.

H10 Independent entering firms display higher failure rates than dependent, diversifying entrants.

\subsubsection{Failure and firm growth}

The empirical results for growth and failure chances of new establishments indicate a negative association. These outcomes are obtained by empirical studies comparing the growth rates of surviving and failing entrants and by those tracing the pre-exit performance of firms.

In the first line of research, failing entrants appear to grow slower than surviving entrants in the years subsequent to entry, and thus in those preceding exit. For instance, Audretsch (1995) reports growth rates over a period of eight years following entry of 127 percent and 135 percent, respectively, for firms failing after eight years and for firms surviving the ten years covered by the study. However, Audretsch (1995) also notes that across industries, large differences exist between the post-entry growth rates of failing and surviving entrants. While in some industries surviving companies displayed growth rates that were much higher than those exhibited by failers (e.g., un transportation and equipment industries), in several other industries (such as food and leather sectors) Audretsch observes that the "mean growth rates of exiting firms tended to exceed those of the cohort of firms that survived throughout the whole period" (Audretsch, 1995: 446)! Apparently, exit is not always preceded by relatively slow growth. Unfortunately, results obtained in this study give no clear insight into the growth pattern during the years preceding exit - i.e, they give no indication as to what extent growth occurred directly after entry or directly prior to exit.

One study in the Industrial Organization tradition, by Troske (1993), explicitly examines the growth patterns of firms in the years preceding failure ${ }^{2}$. Troske (1993) observes a decline in average size that starts five years prior to exit, both in service and in manufacturing industries. In both sectors, the largest drop in average size occurred one year before exit. While manufacturing exiters declined, on average, by 50 percent in size over five years, failing firms in service

\footnotetext{
${ }^{2}$ On this lopme there is in tradition in Organizution Studies (see, e. g., Hambrick and D'Aveni, 1988)
} 
industries experienced an average decrease in size of 45 percent over eight years prior to axt ${ }^{3}$. Finally, manufacturing firms appeared to exit at a smaller relative size (i, e, relative to the size of all firms in the industry) than did service firms. However, the latter finding is not surprising given the fact that the average size of manufacturing firms is larger than the average size of service firms.

The differences in the duration of the decline pattern prior to exit observed between manufacturing firms and service firms (Troske) may be explained by the differences in firm size. The manufacturing companies employed 75 people, on average, whereas the service firms had an average staff size of 11 employees. There are a number of reasons to suspect why large firms may remain longer alive while performing badly than small firms. For instance, large firms may have more financial slack and/or higher sunk costs that retain them from exiting the industry in an early phase of decline. In this line of reasoning, it is argued to be more devastating for smaller firms to have slow growth rates than for larger firms (Dunne and Hughes, 1994). Dunne and Hughes (1994) find evidence that slow growth for smaller entrants is more likely to lead to exit than small growth of large entrants. These authors argue that "whereas slow growing large firms may simply slip slowly downwards through the size distribution for a considerable length of time before exiting altogether, a smaller company will hit the boundary of extinction much sooner" (Dunne and Hughes: 122). For the present study exit is supposed to be preceded by slow growth - i.e., by slower growth than the pace displayed by surviving firms. Since the research sample consists of relatively small firms, advertising agencies, the slow growth probably involves a rather short pre-exit time period.

H11 Exit is negatively related to firm growth.

\subsubsection{Failure and productivity}

Jovanovic (1982) argues that the least efficient firms are the first to exit from the industry. Empirical evidence indeed suggests that the productivity level of failing entrints is below the average productivity level of surviving entrants. For instance, Baldwin and Rafiquzzaman (1995) observe an initial productivity level for entrants surviving the period under study of 83 percent of the incumbent level and a productivity level of 69 percent for failing entrants. Liu (1993) reports a decrease over time in the productivity level of exiting entrants. Furthermore, while not always significant, the studies reviewed here observe, in accordance with recent empiricall studies in manufacturing industries (Doms et al., 1995), that higher productivity is associated with lower failure rates. The hypothesis formulated for the Dutch advertising

\footnotetext{
${ }^{3}$ This result is well-known from the Orgenization Studies literature (see, e.g., Hambrick and Dy Aveni, 1988 s and Weitzell and Jotussion, 1989).
} 
Industry is in accordance with these findings.

H12 Ext is negatively associated to firm productivity.

\subsection{Methods}

\subsubsection{Sample and measurement}

The research sample consists of 318 Dutch advertising agencies over the period 1984-1994, yielding 2321 observations. For detailed information on the outlines of the sample, the reader is referred to Chapter 2. Entry and exit are defined as entry to and exit from the research sample. Entry and exit cohorts are identified annually, and are followed each year until, at most, nine years subsequent to entry or prior to exit.

The size of advertising agencies is measured in terms of gross agency income, in millions of Dutch guilders (constant 1985 prices). Gross agency income is the difference between the sum of money invoiced to clients and the amounts paid to suppliers (on behalf of the clients). The amounts paid to suppliers on behalf of advertisers mainly concern media payments ${ }^{4}$. As both agency income and staff size measures are avallable, the analyses include two measures of firm growth: gross income growth and staff growth. Income growth is a frequently used measure in the advertising industry to examine agency performance, being measured as: (income, - income

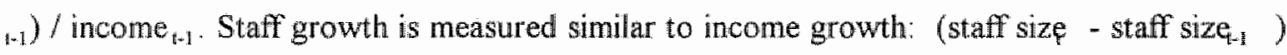
/staff size n. A next performance proxy is the productivity level of firms. Productivity is measured here as gross agency income divided by staff size, which comes close to the measure used by Doms et al. (1995) of (the log of) value added per worker. For the measurement of market shares of entry cohorts, the reader is referred to Section 3.4.

\subsubsection{Analyses}

In order to test the hypotheses on the post-entry and pre-exit performance of advertising agencies, different methods are applied. In doing so, this chapter is a search for convergent evidence as to the features (that differentiate different types) of advertising agencies in terms of their post-entry and pre-exit performance.

The post-entry performance of advertising agencies, in terms of the relationships of age with failure, size, growth and productivity, captured by Hypotheses 1,4,5 and 6 are tested (i) by comparing the post-entry performance of entrants with the performance of incumbent firms in $i+1$ trough $t+9$ and (ii) by following the failure rates, size, growth and productivity of entrants

\footnotetext{
4. That is, the sun advertisers pay for imedis space is paid to the ageney who transfers it to the media. Advertising agencies reseye a commission over the transaction. Gross agency incone only includes the commission on media paymert ts, not the contre costs. Previously argencies recelved is 15 percent commission of the mediat apuce cosis. This rule was stretty followed in tomer years, but pexently chaflenged by advertisers. In the remainder of this book gross income and income will be used intuerchangeably.
} 
during the first nine years after entry. In this analysis, entrants refer to advertising agencies that enter the data set between 1985 and 1994, whereas incumbent firms represent firms that were in the data set from the first year of the time period under study in 1984. Incumbent agencies are founded, on average, in 1965, while entrants to the sample started, on average, in 1978 . As incumbent agencies are substantially older than entering companies, thirteen years on average, the influence of age on the diverse performance measures can be suitably tested by comparisons between these groups. Differences between the performance of the groups are analyzed using Mann-Withney $U$ tests. The age of agencies is directly related to the performance measures by means of OLS regression analyses.

The relationship between age and market shares (Hypothesis 2) is examined exploratively by following the shares of entry cohorts over the first inine years after entry and by computing correlations. The influence of ownership status on start-up size (Hypothesis 3 ) is investigated by comparing the respective sizes of both groups of entrants (independent and dependent newcomers) in the year of entry, applying Mann-Withney $U$ tests. The effect of size on growth and productivity (Hypothesis 7 and 8) is shortly tested with (partial) correlations and OLS regression analyses.

The study of the pre-exit performance of advertising firms differentiates between various modes of exit. In Chapter 2, four exit categories were distinguished. Two of the categories, bankruptcy and dissolution, consist of a limited number of observations. Since the differences between these two groups are negligible, they are taken together for this chapter's analysis. A distinction is, thus, made between agencies that exit the sample because of (i) bankruptcy or dissolution, (ii) merger or acquisition and (iii) insufficient data.

Differences in the exit rates between independent and dependent start-ups (Hypothesis 10) are analyzed by means of a Fisher's Exact test. In order to analyze the relationships of failure with size, growth and productivity (Hypotheses 9,11 and 12) two analyses are carried out. First, a comparison is made between the size, income growth, staff growth and productivity level of exiting agencies and survivors in $t-1$ through $t-9$. Failers represent all agencies, either entrants or incumbents, that disappear from the data set before 1994. Surviving agencies refer to all agencies, either entrants or incumbents, that are still in the sample by 1994 For each of the variables, Kruskal-Wallis statistics are calculated in order to detect differences between the means of the various groups. For surviving agencies and each of the three groups of exiters, Mann-Withney $U$ tests are executed.

Second, an analysis of the performance of matched pairs of failing and surviving advertising agencies is carried out over the years preceding exit. Income growth, staff growth and productivity of pairs of failing and surviving agencies are compared during five or eight years prior to exit. The matched-pair design is a suitable methodology for a comparative study of failing and surviving firms. The idea behind this research design can be summarized in five steps 
1. The dependent variable is the status of the firm in year $t_{n} y_{1}$; failing $\left(y_{t}=0\right)$ or survival $\left(y_{1}=1\right)$.

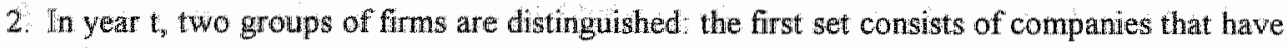
disappeared from the market, the so-called failers, while the second group comprises firms that are still active in the market in year t, the so-called survivors.

3. The history of the firms in terms of $n$ possible determining factors $x^{i}(i=1, \ldots, n)$ is described with time series $x_{x} \cdot x_{k-z}, \ldots, x_{i}^{i}$ In general, the time frame of the analysis is five $(z=4)$ or ten $(z=9)$ years.

4. In year $t-z$, pairs of firms $-B^{a}-B^{b}$ - with a similar position are matched. It is important to identify the key factors $x_{1-2}^{i}$ on the basis of which the matching takes place. Generally, couples of firms are identified on the basis of proxies for size and profitability.

5. The walues of the factors $x^{i}(i=1, \ldots, n)$ of all pairs $B^{n}-B^{3}$ are compared for each year. Significant differences - over the whole period and for each year - are traced by applying (onesided) Wilcoxon ranksum tests. It must be noted that between the pairs differences may exist as to the five years preceding failure. That is, one couple may be followed from, for instance, 1985 through 1989 (the year of exit of the failer), while a next pair may be examined from 1988 untill 1992 (the year of failure of one of the agencies)

For the identification of pairs of advertising agencies, the failing agencies were taken as a starting point. Failure referred to one of the three exit modes, bankruptcy/dissolution, insufficient data and merger/acquisition. A distinction was made between pairs of entering agencies (agencies that entered the data set after 1984), and pairs of incumbent agencies (i.e., firms that were included in the sample in 1984). Since the criteria of entry to the sample, as described in Chapter 2, are based on financial stability and size characteristics, this distinction seemed appropriate.

Pairs of entronts are identified based on their year of entry to the sample, their initial size (staff size and gross income), ownership in the year of entry and founding year. The latter matching criterion is important given the applied entry procedure, which implies that founding year and entry year rarely coincide. Ten pairs of failing and surviving entrants could be identified. While the couples are not always perfect, in most instances a close match could be obtained. Most difficult appeared to be the founding year of agencies. In an extreme case, the difference attains thirteen years. All twenty agencies included in this analysis entered the sample between 1985 and 1989; the failing agencies exited again between 1992 and 1994. All agencies are, at the time of entry, independent ${ }^{6}$ and relatively small. Four out of the ten failing

\footnotetext{
Shro at the lime of entry to the sumple.

"For a few agencis: the ownership dummy is raissing, but given the information on the ownership an other years, it can be assumed they are owned by bourd members in the year of entry to the samate.
} 
entrants exited the sample because of bankruptcy or dissolution, five disappeared with insutt:cient data and one entrant was taken ower during the time period. Unfortunately, the number of pairs of entrants is insufficient to carry out the analysis separately for pairs with different exit modes. The performance of the pairs of agencies in terms of income growth, staff growth and productivity is tracked until five years preceding failure.

Pairs of incumbents, agencies that were included in the sample in 1984, are matched on their founding year, ownership status and size (staft size and income) in 1984. A sufficient number of failing and surviving incumbent agencies allowed for a separate matched-pair analysis for each of the three exit modes. Eight pairs of bankrupt or dissoluted and surviving incumbents are established, twelve couples of 'insufficient data exiters' and matched surviwors are found, and, finally, eight pairs of nerged or acquired and surviving agencies are identified. Again, while the pairs are not perfect, they are rather well matched. The strongest divergences may be found in the gross income of failers and survivors within several pairs. The performance, i.e, income growth, staff growth and productivity, of these couples is traced until eight years prior to exit. In the Appendix, the matched pairs of agencies and their descriptives are reproduced.

A matched-pair design analysis has several important advantages. One is that it prowides controls for other possibly explaining variables. While traditional analyses of the post-entry performance of firms have included independent variables such as age, ownership, size, MES (minimum efficient scale), concentration, density and market growth, these are all controlled for with the present research design. The aim of this exercise is to assess to what extent, and from what point in time, the performance of failing agencies diverges from the performance of their surviving counterparts in the years preceding failure, holding several potential explaining variables constant. Again, the present analysis is limited to variables traditionally used in the industrial organization literature. This does, thus, not imply that the importance of other explaining variables is not recognized: in effect, some of these are addressed in later chapters.

In summary, the analyses applied to test the hypotheses are (i) (partial) correlation analysis, regression analysis, Chi-Square and Fisher"s Exact tests, (ii) post-entry performance analysis, by comparing the performance of entering firms with the performance of incumbent companies (iii) pre-exit performance analysis through the comparison of the performance of exiting and surviving agencies and (iv) pre-exit performance analysis by means of a matched pair design. Table 3.2 summarizes the analyses and techniques which are used to test the hypotheses. 
Table 3.2: Analysey and techniques

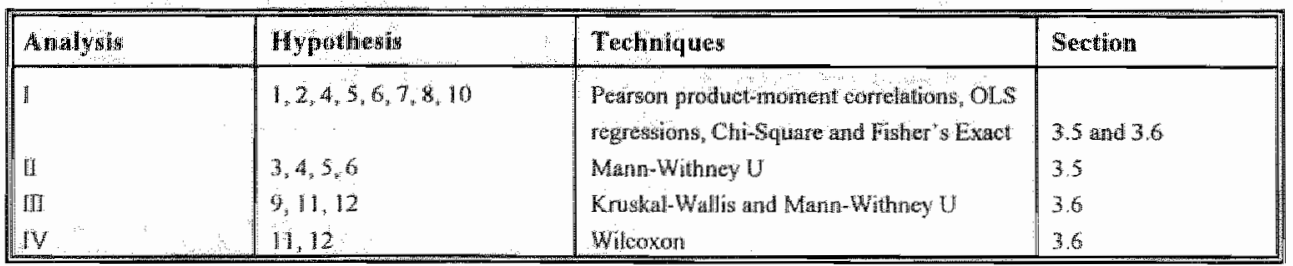

The correlation matrix of the variables is given in Table 3.3 . The variable market shares is omitted from the matrix since these refer to the shares of cohorts of entrants and cannot usefully be related to the other variables, which are measured at the individual agency level. Table 3,3 reweals that while many correlations are significant, only a limited number of correlations are substantial. The correlation between income and staff size strikes the eye, indicating that the two size measures are nearly substitutes.

Table 3.3: Correlation matrix

\begin{tabular}{|c|c|c|c|c|c|c|c|c|c|}
\hline & $A_{i g}$ & Iexit & Inecomer, & Income & $\begin{array}{l}\text { Staff } \\
\text { size }_{\text {it }}\end{array}$ & $\begin{array}{l}\text { Incoune } \\
\text { growth }\end{array}$ & $\begin{array}{l}\text { Sianf } \\
\text { growth }\end{array}$ & Prod. & $\begin{array}{l}\text { Owix } \\
\text { erstup }\end{array}$ \\
\hline Age & 1.00 & & & & & & & & \\
\hline Exilit ${ }^{y}$ & $\infty, 0119$ & 1.000 & & & & & & & \\
\hline Incorne, & $.119 * * * *$ & $042 *$ & 1.00 & & & & & & \\
\hline Ineco:me & $.120 * *$ & $038^{*}$ & 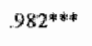 & 1.000 & & & & & \\
\hline Semfrsize; & $1.44 * * * *$ & $\times 0.0544^{*} \approx *$ & .9419 ***: & $.941^{*}$ & 1.00 & & & & \\
\hline Incone growth & $-162^{* * *}$ & .022 & .028 & $-.099^{* * * *}$ & $0.05: 1 *$ & 1.00 & & & \\
\hline Sturr growitu & $\because 119$ an: & -122 & -.031 & $-0.082 * 16 *$ & .001 & AlOs: & 0.00 & & \\
\hline proullatefivelly & $=09 \rrbracket^{*}$ & .012 & 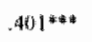 & 394 进米㡐 & $218 *$ & 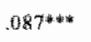 & $43.3 \%$ & 1.00 & \\
\hline Oxwnership & $0 \mathrm{yg}^{2 *}$ & -610 & $.503^{0: 1 *}$ & $504 * * 4$ & $517^{* * 4}$ & .011 & -.007 & $.269 * 8$ & 1.00 \\
\hline
\end{tabular}

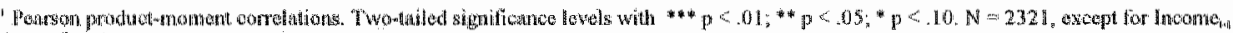

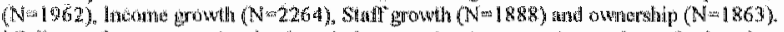

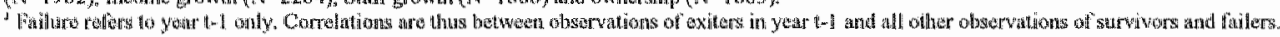

\subsection{Annual entry and exit statistics}

Before turning to the testing of the hypotheses, a general description of the annual magnitude of entry into and exit from the Dutch advertising industry seems in place. The size of entry and exit is assessed in terms of annual rates. The magnitude of both phenomena is expressed through market shares of entrants and exiters as well as with their size relative to the other (non-entering or non-exiting, respectively) agencies in the industry. The measurement equations follow those used in previous work on entry and exit (e.g., Dunne et al., 1988; 
Slleuwaegen and Dehandschutter, 1991).

Relative size of entrantis:

Entry rate

Exit rate:

Matkef shares of entrank:

Market shares of exiters:

(6)
$R S E=\frac{G E(t) / N E(t)}{(G T(t)-\operatorname{CRE}(0))(N T(t)-\operatorname{NE}(0)}$

$$
\begin{aligned}
& E N R=N E(N) / N T(t-1) \\
& E X R=M A(N) / N R(-1) \\
& \text { ASE }=G H E(G), G T(0) \\
& M S X=G L(t) / G M(t-1)
\end{aligned}
$$

$R S X=\frac{G L C O N W(t)}{(G M T(t-1)-G L X(t)) /(N T(1-1)-N X(i))}$

with

$N T(t)=$ total number of agencies in the sample in year $\mathbb{l}^{*}$

$N E(t)=$ total number of agencies entering the sample in year $t$;

$\mathrm{Ar}(\mathrm{l})=$ lotal number of agencies exitung the sample between yean $t-1$ and year $t$

$G T(t)=$ tolal gross income of all agencies in the sample in yeat

$(G / f(t)=$ total gross income of agencies entaring the stmpla in year 1 ;

$G L X(t)=$ total gross income of agencies exiting the sample between year $t-1$ and year $t^{1 !}$

Table 3.4 and Figures 3.1 and 3.2 present the extent of entry and exit into and from the sample. The size of the sample of Dutch advertising agencies increases from a total of 171 agencies in 1984 to 225 agencies in 1994. Between the first and last year of the study, the sample increases with 54 agencies, showing a mean annual met entry rate of almost 3 percent. During the 1985 1994 period, an average of 15 agencies enter the sample annually, while 9 agencies exit the sample, on average.

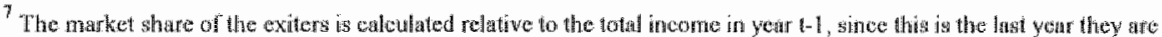
inchided in the stample (and thein income was measured')

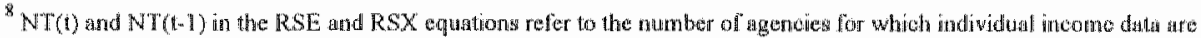

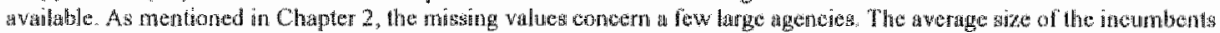
is therefore a bit underestimated, which in turn overestanates the relative saze of exalers and entrants womexwht.

Fee supra note 8

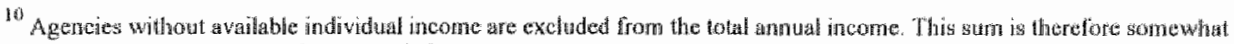
underestimated, especially since the missing values conoern the larger agencies.

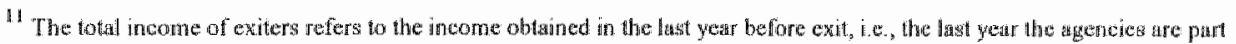
of the sample ( $(-1)$. 
Table 3.4: Enry ino and ext from the sawple

\begin{tabular}{|c|c|c|c|c|c|c|c|}
\hline Hoa & $\mathbb{N}$ & $\begin{array}{l}\text { Allowithe } \\
\text { nut wrothy } \\
(54)\end{array}$ & $\begin{array}{l}\text { Netions ent } \\
\text { rate }\end{array}$ & $\begin{array}{l}\text { Absolute } \\
\text { grass enitiy } \\
\text { (147) }\end{array}$ & $\begin{array}{l}\text { Ciroiss enilary } \\
\text { ratte }\end{array}$ & $\begin{array}{l}\text { Alswolute } \\
\text { gross exit } \\
\text { (93) }\end{array}$ & $\begin{array}{l}\text { Gross exit } \\
\text { ratio }\end{array}$ \\
\hline 1984 & 171 & $*$ & . & . & - & . & . \\
\hline 1985 & $m 7$ & 6 & 3.510 & 14 & $8.19 \%$ & 8. & $4.68 \%$ \\
\hline 19866 & 188 & 11 & 6210 & 16 & $9.04 \%$ & 5 & $2.82 \%$ \\
\hline 1987 & 201 & 13 & $6.91 \%$ & 21 & $11.17 \%$ & 8 & $426 \%$ \\
\hline 1988 & 206 & 5 & $2.49 \%$ & 12 & $9.97 \%$ & 7 & $3.48 \%$ \\
\hline 1989 & 215 & i) & $437 \%$ & 16 & $7.77 \%$ & 7 & $3.40 \%$ \\
\hline 1990 & 226 & 11 & $\$ .12 \%$ & 15 & $698 \%$ & 4 & $1.86 \%$ \\
\hline 1999! & 233 & 7 & $3.10 \%$ & 16 & $7.08 \%$ & 9 & $3.98 \%$ \\
\hline 1992 & 245 & 12 & $5.15 \%$ & 26 & $11116 \%$ & 14 & $6,01 \%$ \\
\hline 1993 & 234 & .1 & $-4,49 \%$ & 10 & $4.08^{\mathrm{o}}$ & 21 & $8.57 \%$ \\
\hline 1994 & 225 & -9 & $-3.85 \%$ & 1 & $0.43 \%$ & 10. & $4.27 \%$ \\
\hline Mewin & 211 & $\$ 40$ & $2.85 \%$ & 14.70 & $7.19 \%$ & 9.30 & $4.33 \%$ \\
\hline
\end{tabular}

Figure 3.1: Absolute entry and exit

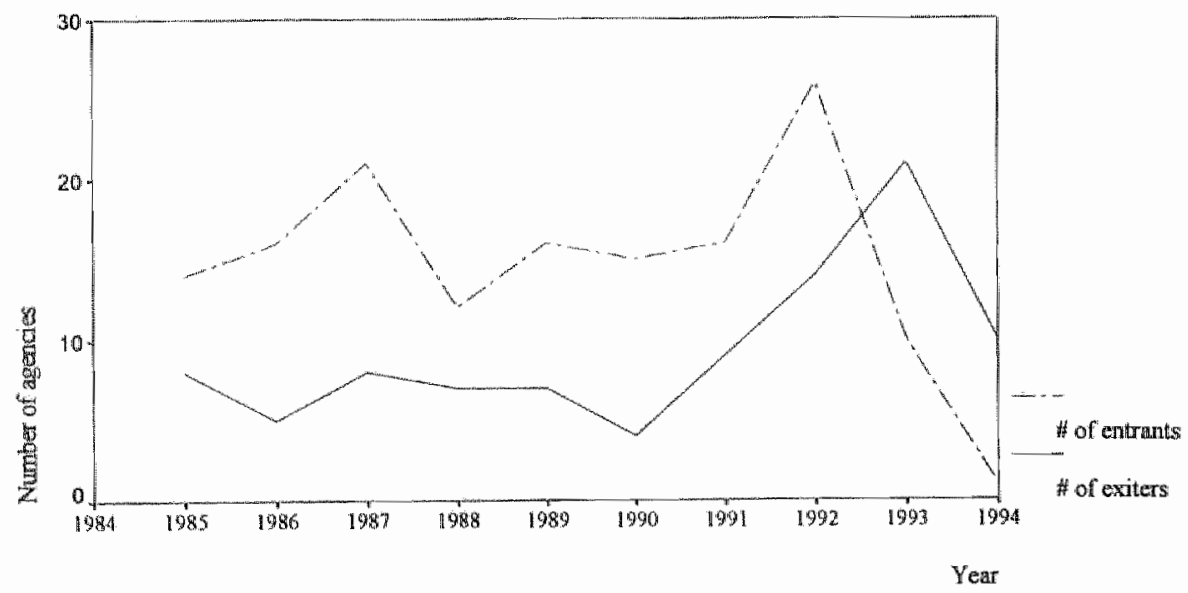


Figure 3.2: Entry and exit rates

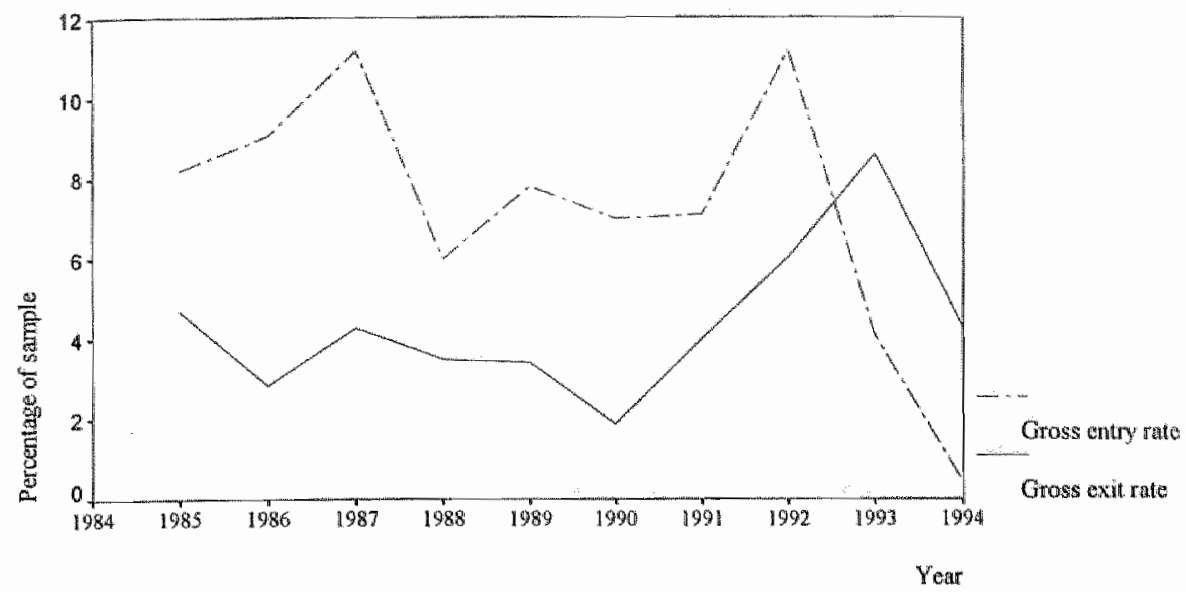

The mean gross entry and exit rates over the ten-year period are 7.33 percent and 4.35 percent, respectively. Both rates are substantially lower than the gross entry and exit rates observed in Belgian service industries of 13 and 12 percent, respectively (Cable and Schwalbach, 1991). Again, this difference is probably due to the fact that the current study pertains to entry to the sample, i.e., to the segment of larger and financially stable advertising agencies. However, the gross entry rate is somewhat higher and the exit rate lower than the rates reported for manufacturing industries, which are both around 6.5 percent (Cable and Schwalbach, 1991).

The number of agencies in the sample increases untill 1992, and decreases in 1993 and 1994 : gross entry exceeds gross exit until 1992, while the opposite is true for 1993 and 1994. The entry and exit rates are negatively, but insignificantly, related $(-15)$, and so are the number of entrants and exiters (-.08). However, exit appears to be positively affected by entry in the preceding year a positive but insignificant correlation is found between the gross exit rate and the gross entry rate in the previous period (33). Entry, in turn, reveals to be negatively and significantly related to exit in the previous year $(-.78: p<.05)$. Apparently entry is attracted by low exit rates and discouraged by high exit rates in the preceding period.

\subsection{Market shares and average size}

While the entry and exit rates differ substantially from each other, this is not so much the case for the market shares of entrants and exiters. Whereas substantial differences exist per year, both groups achieve average annual market shares of nearly 3.3 percent of total sample income 
(see Table 3.5 and Figure 3.3 ).

Table 3.5. Fntry and exit wariables (in percentages)

\begin{tabular}{|c|c|c|c|c|c|c|c|c|c|c|c|}
\hline & Mean & 1985 & 1986 & 1987 & 1988 & 1989 & 1990 & 1991 & 1992 & 1993 & 1994 \\
\hline Rntry mate & $\begin{array}{l}319 \\
0.22)\end{array}$ & $\$ 1 \%$ & 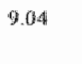 & 11.17 & 597 & 7.77 & 6.98 & 708 & 11.16 & 4.08 & -43 \\
\hline 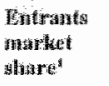 & $\begin{array}{l}3.24 \\
(1.61)\end{array}$ & 2569 & 3.22 & 5.39 & 3.72 & 4.55 & 3.26 & 3.80 & 4.59 & 1.19 & .07 \\
\hline 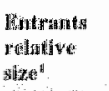 & $\begin{array}{l}41.28 \\
(1.4 .46\end{array}$ & $30.5 \mathrm{~g}$ & 35.19 & 48.06 & 60.51 & 57.54 & 46.09 & 52.79 & 40.14 & 26.73 & 15.17 \\
\hline Bxill rats & $\begin{array}{l}4.33 \\
(1.86)\end{array}$ & 4.68 & 2.82 & 4.26 & 3.48 & 340 & 1.86 & 3.98 & 6.01 & 8.57 & 427 \\
\hline 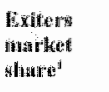 & $\begin{array}{l}3.28 \\
(1.72)\end{array}$ & 2.72 & 493 & 2.59 & 4.12 & 1.90 & .75 & 5.20 & 2.45 & 6.14 & 205 \\
\hline 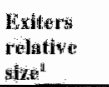 & $\begin{array}{l}78.36 \\
(46.35)\end{array}$ & 36.27 & 176.15 & 58.84 & 117.29 & 53.53 & 3863 & 128.55 & 3875 & 69.100 & 46.49 \\
\hline
\end{tabular}

1 Mears sure and averages widh standard dowitions in parentheses.

Figure 3.3: Matke shares of entrants and exiters:

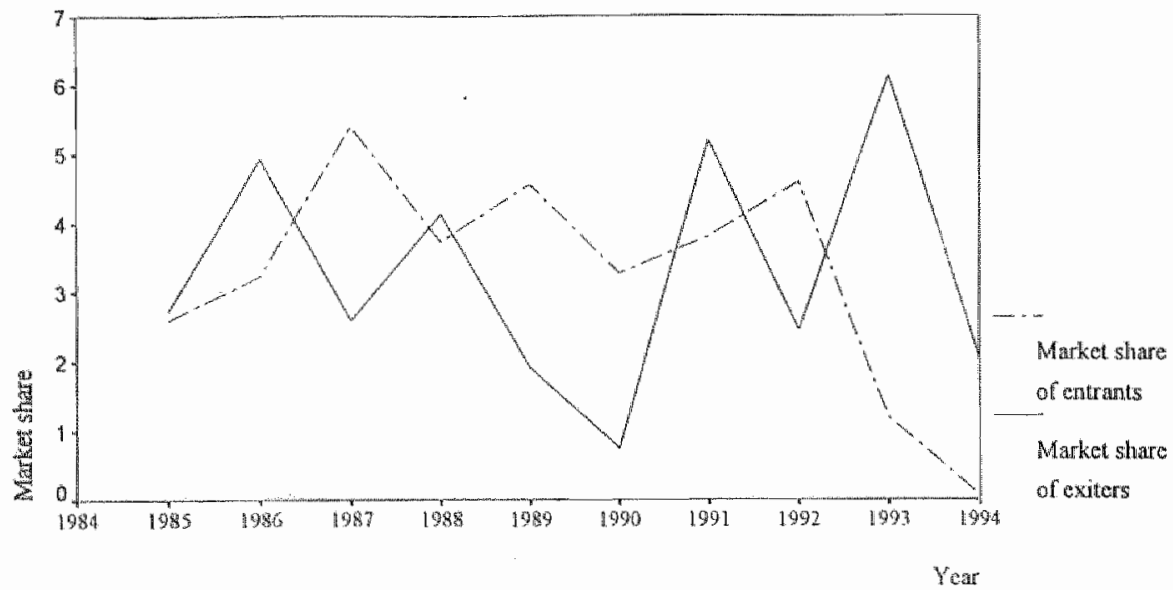

The market shares obtained by newly established Dutch agencies are one percent lower than the average of 4.4 percent market shares gained by entrants in Belgian service industries, but somewhat higher than the 2.8 percent average market shares observed for entrants in 
manufacturing industries in eight countries (Cable and Schwalbach, 1991).

The market shares of entrants and exters are negatively but insignificantly related (- 19). However, while we observe no difference between market shares of entrants and exiters, the total sample income does increase over the time period. This inconsistency is explained by the fact that almost one third of the exiters represents agencies that merge with another agency. These merging firms disappear from the sample as an individual agency, while their income remains within the sample.

Both entrants and exiters are, on average, smaller than their surviving counterparts. This is revealed by the fact that the entry and exit rates exceed the entrants' and exiters' market shares. Furthermore, the agencies exiting the sample appear to be larger, on average than the firms that enter the sample. This is pointed out by the fact that a similar market share is obtained by a smaller average rate of exiters than the rate of entrants. Examination of the average relative size of entrants and exiters compared to incumbents confirms these observations. Both entrants and exiters are, on average, smaller than incumbent firms, and exiting agencies are, on average, twice as large as entrants (see Table 3.5 and Figure 3.4). The average size of the agencies in the ten groups of entrants in the year they enter the sample is 41 percent of the size of incumbent agencies. This is twice as large as the average size of 20 percent of incumbents that was reported for new establishments in Belgian service industries and observed in manufacturing industries in eight countries (Cable and Schwalbach, 1991). This points to the fact that the present sample excludes the smallest firms from the industry.

Figure 3.4: Relative size of entrants and exiters

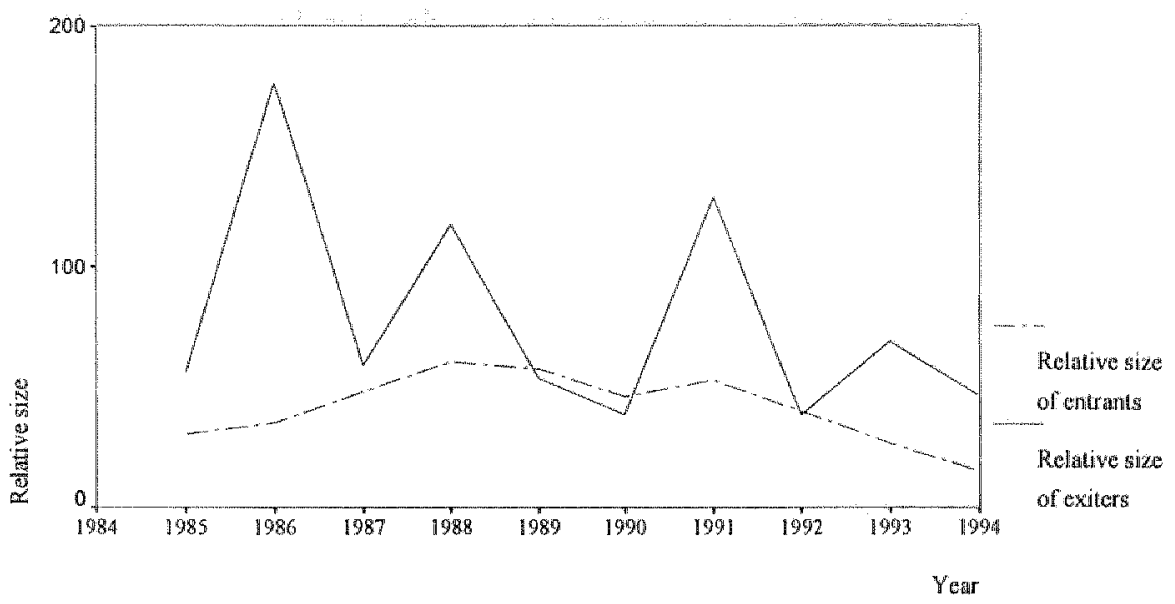

The size of exiting agencies, on the other hand, is much larger. In the last year before exit, the 
average income of exiting agencies represents about 78 percent of the average income of nonexiting agencies. However, not only the average relative size of exiters is high, so is the variation: at standard deviation of 46 percent is reported. A closer look at the group of exiters learns that especially the agencies that exit because of a merger are relatively large (see Figure 3.5). Of course, their relatively large size makes agencies attractive candidates for merger or take-over. Especially in 1986, 1988, 1991 and 1993 the relative average size of exiters is extremely high, all being years in which several large agencies have merged

Figure 3.5: Average relative size of exiters

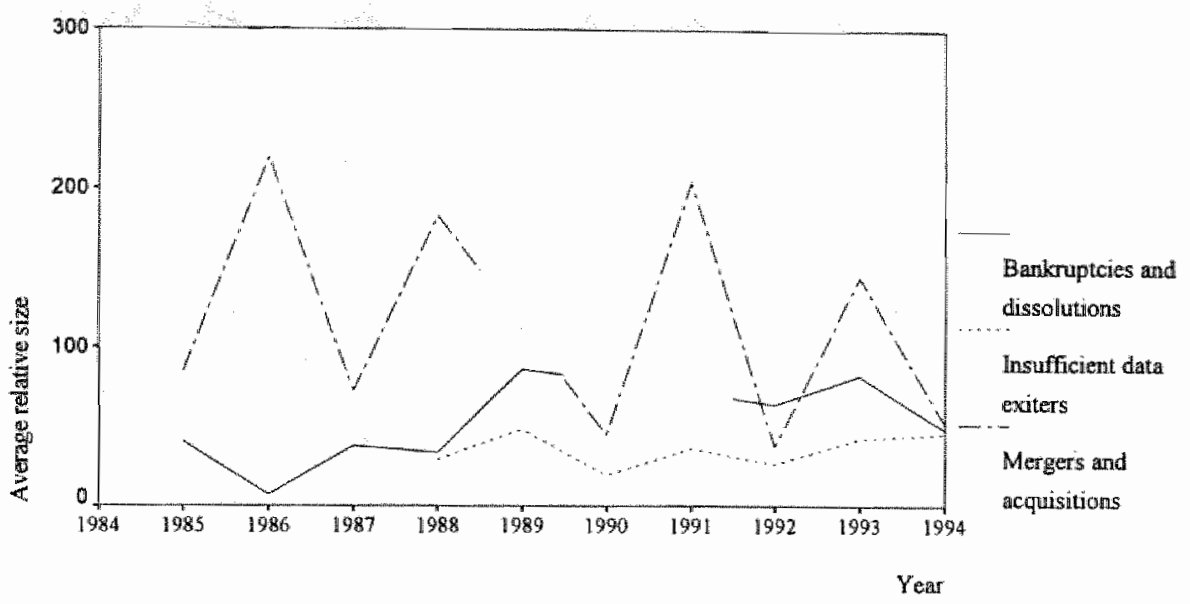

\subsection{Post-entry performance in the Dutch advertising industry}

This section focuses on the results with respect to the performance of Dutch advertising agencies in the years following entry to the sample. Consistent with prior research, also in this Dutch service industry, independent entrants represent the largest number of entrants. Table 3.6 shows that of the 147 entries that occurred during the 1985 - 1994 period, 68.80 percent are independent firms, owned by board members. Dependent agencies, which are owned, at least in part, by large, mostly multinational, agencies, make up 8.84 percent of all entrants during the time period. Unfortunately, of 23.13 percent of entrants the ownership status is unknown. Since the category of missing values is fairly large and the category of diversified entrants consists of few observations, in testing the remaining hypotheses the distinction between independent and dependent entrants is not explicitly made. 
Table 3:6: Categories of entrams

\begin{tabular}{|c|c|}
\hline Emmants & $\begin{array}{l}\text { Percentage of sumple } \\
(N-14 \pi)\end{array}$ \\
\hline Indlependent ageneies & $\begin{array}{l}68.80 \% \\
(100)\end{array}$ \\
\hline Dependent, divensiffed agencies & $\begin{array}{l}8.84 \% \\
(13)\end{array}$ \\
\hline Unknow口 & $\begin{array}{l}23.13 \% \\
134)\end{array}$ \\
\hline
\end{tabular}

1. Percentages are giwen with $\mathrm{N}$ in parenthesies.

\subsection{A Age and exit rates}

Hypothesis 1, predicting a negative relationship between age and failure, is not confirmed by the results. The findings reveal that the exit rates of entrants are lower than the exit rates of ncumbent agencies. Except for the 1990 entrants which are all still "alive" by 1994, between 10 percent and 54 percent of each year's entrants have exited the sample by 1994. The exit rates of entrants tend to grow steadily during the years after entry. In the first year subsequent to entry, an average of 3 percent of the agencies already exited the sample; after nine years this value has reached 50 percent of the (1985) entrants. The cumulative exit rate of incumbents exceeds the entrants" cumulative exit rate until eight years after entry. Only nine years after the year of entry have entrants caught up with incumbents in this respect. Table 3.7 gives the cumulative exit rates of the entrants and incumbents. Contrary to the expectations, over the ten-year time period, the percentage of incumbents disappearing from the sample exceeds the percentage of entrants that exit from the data set. Of the 1.46 agencies entering the sample between 1985 and 1993 (the only entrant in 1994 is not counted since it cannot exit in the same year), 30 exited subsequently, which is 20.41 percent. Of the 171 agencies that were in the sample from the beginning of the time period, 63 failed during the ten subsequent years, which represents 36.84 percent. A Pearson Chi-Square test indicates that the difference between these percentages is significant $(p<.01)$. However, an additional correlation between firm age and exit, controlling for firm size, over the whole sample produces the predicted negative relationship $(\mathrm{p}<0.5)^{12}$. Separate correlations among entrants and incumbents generate the expected results too. These contradicting outcomes can be explained by the applied entry criteria. Entrants have just succeeded in obtaining a certain size threshold and have shown to be financially stable. They should be able to benefit from this position at least in the few years that follow. Their incumbent counterparts, on the other hand, being in the data set

\footnotetext{
12. In tuddition, a correlation between founding year and exit, comprising all year obserwations of exilers and wurvivar: produces a positive, though insignificant outconne, indicating a weak negatiwe relationshing between age and crit. Uwing the age of agencies may wongly sugges that an agency of the age of five years exits the sample, while it ate tually only exits at the age of nine. A correlation at an aggregate level between the variables produces an intignilieant prositive value, low.
} 
from 1984 onwards are not specifically financially stable in 1984 and may for that reason exit more frequently in the years that follow (see Table 3.10 - 3.13 for a performance comparison between entrants and incumbents). This situation may occur while firm age is negatively related to extit.

Table 3.7: Cumwative exil rates

\begin{tabular}{|c|c|c|c|c|c|c|c|c|c|c|}
\hline 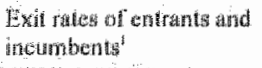 & $t$ & $1+1$ & $1+2$ & $t+3$ & $t+4$ & $t+5$ & $t+6$ & $t+7$ & $t+8$ & $t+9$ \\
\hline 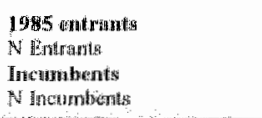 & $\begin{array}{l}14 \\
163\end{array}$ & $\begin{array}{l}.00 \\
14 \\
.03 \\
198\end{array}$ & $\begin{array}{l}000 \\
14 \\
08 \\
150\end{array}$ & $\begin{array}{l}07 \\
13 \\
12 \\
144\end{array}$ & $\begin{array}{l}14 \\
12 \\
15 \\
141\end{array}$ & $\begin{array}{l}.14 \\
12 \\
.17 \\
138\end{array}$ & $\begin{array}{l}.21 \\
11 \\
21 \\
132\end{array}$ & $\begin{array}{l}21 \\
11 \\
28 \\
123\end{array}$ & $\begin{array}{l}38 \\
9 \\
38 \\
111\end{array}$ & $\begin{array}{l}50 \\
7 \\
40 \\
109\end{array}$ \\
\hline 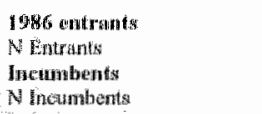 & 168 & $\begin{array}{l}.00 \\
16 \\
65 \\
1.50\end{array}$ & $\begin{array}{l}.00 \\
16 \\
.09 \\
144\end{array}$ & $\begin{array}{l}.13 \\
14 \\
11 \\
14\end{array}$ & $\begin{array}{l}19 \\
13 \\
17 \\
138\end{array}$ & $\begin{array}{l}19 \\
13 \\
18 \\
132\end{array}$ & $\begin{array}{l}25 \\
12 \\
24 \\
123\end{array}$ & $\begin{array}{l}31 \\
11 \\
34 \\
111\end{array}$ & $\begin{array}{l}38 \\
10 \\
37 \\
108\end{array}$ & \\
\hline 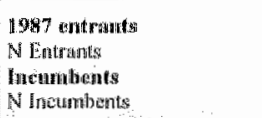 & 21 & $\begin{array}{l}.00 \\
21 \\
04 \\
1.44\end{array}$ & $\begin{array}{l}.05 \\
20 \\
.06 \\
1040\end{array}$ & $\begin{array}{l}.05 \\
20 \\
.08 \\
138\end{array}$ & $\begin{array}{l}10 \\
19 \\
13 \\
132\end{array}$ & $\begin{array}{l}14 \\
18 \\
19 \\
123\end{array}$ & $\begin{array}{l}.14 \\
18 \\
.29 \\
111\end{array}$ & $\begin{array}{l}.14 \\
1.8 \\
.32 \\
108\end{array}$ & & \\
\hline 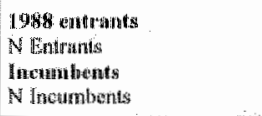 & 144 & $\begin{array}{l}.00 \\
12 \\
.02 \\
141\end{array}$ & $\begin{array}{l}.100 \\
12 \\
.04 \\
138\end{array}$ & $\begin{array}{l}08 \\
111 \\
139\end{array}$ & $\begin{array}{l}.08 \\
11 \\
19 \\
123\end{array}$ & $\begin{array}{l}.08 \\
11 \\
.25 \\
111\end{array}$ & $\begin{array}{l}.17 \\
10 \\
.28 \\
108\end{array}$ & & & \\
\hline 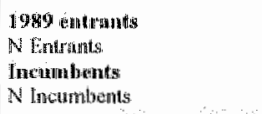 & $\begin{array}{l}16 \\
141\end{array}$ & $\begin{array}{l}.00 \\
16 \\
02 \\
138\end{array}$ & $\begin{array}{l}.00 \\
16 \\
.06 \\
132\end{array}$ & $\begin{array}{l}.06 \\
15 \\
.13 \\
123\end{array}$ & $\begin{array}{l}10 \\
13 \\
23 \\
111\end{array}$ & $\begin{array}{l}.25 \\
12 \\
.25 \\
108\end{array}$ & & & & \\
\hline $\begin{array}{l}1990 \text { entrants } \\
N \text { tontrants } \\
\text { Incumberts } \\
\text { N linenumbents }\end{array}$ & $\begin{array}{l}15 \\
138\end{array}$ & $\begin{array}{l}.00 \\
15 \\
.04 \\
132\end{array}$ & $\begin{array}{l}.00 \\
15 \\
.11 \\
123\end{array}$ & $\begin{array}{l}.00 \\
15 \\
21 \\
111\end{array}$ & $\begin{array}{l}.00 \\
15 \\
.24 \\
1108\end{array}$ & & & & & \\
\hline 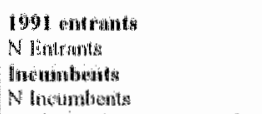 & 113 & $\begin{array}{l}13 \\
14 \\
07 \\
123\end{array}$ & $\begin{array}{l}25 \\
12 \\
17 \\
111\end{array}$ & $\begin{array}{l}25 \\
12 \\
19 \\
108\end{array}$ & & & & & & \\
\hline 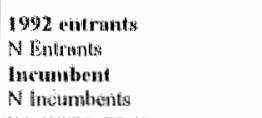 & $\begin{array}{l}26 \\
143\end{array}$ & $\begin{array}{l}.08 \\
24 \\
.110 \\
111\end{array}$ & $\begin{array}{l}12 \\
23 \\
13 \\
108\end{array}$ & & & & & & & \\
\hline 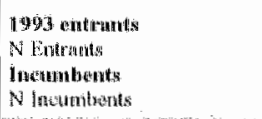 & $\begin{array}{l}10 \\
111\end{array}$ & $\begin{array}{l}.10 \\
9 \\
.07 \\
108\end{array}$ & & & & & & & & \\
\hline 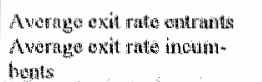 & & .03 & .05 & 19 & .12 & $\frac{16}{2 \pi}$ & .19 & $\begin{array}{l}.22 \\
.31\end{array}$ & $\begin{array}{l}.37 \\
.37\end{array}$ & $\begin{array}{l}.50 \\
.40\end{array}$ \\
\hline
\end{tabular}

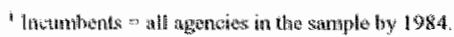

Furthermore, Hypothesis I implies that exit rates decline as entry cohorts age. Again, for this expectation the results give no support. The exit rates seem to increase slowly over time, and then stabilize. The exit rates of incumbents are more stable over time and since the cumulative 
rate of entrants is below the rate of incumbents in +1 but similar in $1+8$, this confirms that, if anything, the exit rates of entrants increase ower time.

The findings point out that the exit rates of entrants are not only lower than those of incumbents, they are also much lower than those observed in former studies, in which a failure rate of 20 percent was generally already abserved after one or two years after entry. The explanation for the divergence with failure rates observed in prior work may, again, be found in the definition of entry in the present sample as the fulfillment of certain criteria. These criteria imply a bias toward the larger and more financially stable agencies that were founded several years befor'e entering the sample. The sample bias ('large' and 'financially healthy' firms) is tricky. However, the matched-pair analyses in Section 3.5.2 - particularly the entrant - entrant couples - control for this.

\subsubsection{Age and market shares}

The market shares of entrants in the post-entry years are summarized in Table 3.8 .

Table 3.8: Post-entry market shares

\begin{tabular}{|c|c|c|c|c|c|c|c|c|c|c|}
\hline Entrants & $t$ & $t+1$ & $t+2$ & $t+3$ & $t+4$ & $t+5$ & $x+6$ & $t+7$ & $t+8$ & $1+9$ \\
\hline 1985 & 2.59 & 3.48 & 4.14 & 4.35 & 4.1 है & 4.66 & $4 \| 3.34$ & 4.23 & 3.84 & 3.70 \\
\hline 1986 & 3.22 & 3.22 & 3.21 & 3.16 & 2.74 & 2.74 & 2.68 & 289 & 2.78 & \\
\hline 1987 & 5,39 & 6.88 & 7.45 & 7.77 & 7.16 & 6.59 & 6.75 & 7.48 & & \\
\hline 1988 & 3.72 & 3.89 & 3.97 & 4.08 & 3.72 & 4.42 & 458 & & & \\
\hline 1989 & 4.55 & 4.97 & 5.23 & 5.33 & 5.002 & 5.00 & & & & \\
\hline 1990 & 326 & 3.76 & 38.5 & $4,0,3$ & 425 & & & & & \\
\hline 1991 & 3.80 & 3.59 & 3.98 & $A, 36$ & & & & & & \\
\hline 1992 & 4.59 & 3.78 & 3.77 & & & & & & & \\
\hline 1993 & 1,19 & 1.18 & & & & & & & & \\
\hline 199.4 & .07 & & & & & & & & & \\
\hline Average & $3.2 \mathrm{~d}$ & 3.86 & A. Ant & 4.73 & 4.51 & 4.67 & 4.59 & 4.87 & 3.31 & 370 \\
\hline
\end{tabular}

In the year of entry the market shares of entrants represent, on average, 3.24 percent of total income in the industry, with a maximum of 5.39 percent for the 1987 entrants and a minimum of .07 percent for the only entrant in 1994. Most cohorts of entrants succeed in increasing their market share over the post-entry period. However, the market shares of the 1986, 1992 and 1993 entrants have declined by 1994 (see Table 3.8). Correlations between the market shares of each entry cohort and post-entry years are, consistent with these findings, positive (and often significant) for the cohorts of 1985, 1987 - 1991 and negative for the 1986 and 1992 
cohorts. For 1993 and 1994 the correlations could, of course, not be calculated. In general, the post-entry market shares of surving entrants increase slowly, to a peak of 4.87 percent of total industry output seven years following entry, and decrease again to 3.70 percent nine years after entry. The decline is caused by the relatively large number of agencies that exits in $t+8$ (see Table 3.7 ).

The results oppose Hypothesis 2 and the findings reported by studies carried out in the manufacturing sector (see Table 3.1). A decline in the market shares of each entry cohort in the post-ntry period was hypothesized and observed in earlier studies. The contradicting finding is surely the to the fact that the failure rates of entrants are not as high as those observed in prior research and that surviving advertising agencies grow relatiwely fast.

\subsubsection{Age and average size}

Table 3.9 provides the average size of independent and dependent entering advertising firms.

Table 3.9: Entry size of independent and dependent entrants

\begin{tabular}{|c|c|c|}
\hline \multirow{2}{*}{$\begin{array}{l}\text { Entrants } \\
N=47\end{array}$} & \multicolumn{2}{|c|}{ Averuge size: } \\
\hline & Incorme & Staff size \\
\hline Independent agencies & $\begin{array}{l}1.39 \\
(1.13)\end{array}$ & $\begin{array}{l}9.57 \\
(9.709)\end{array}$ \\
\hline Dependiant, diversiffed agencies. & $\begin{array}{l}3.60) \\
(1.95)\end{array}$ & $\begin{array}{l}22.38 \\
(15.99)\end{array}$ \\
\hline Mann-Withney $U^{3}$ & $.0000^{* * * * *}$ & $.0000^{* * \hbar}$ \\
\hline
\end{tabular}

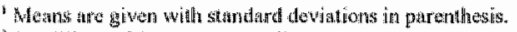

Hir millions of Dutch 1985 Guilders.

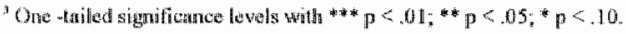

Hypothesis 3 expects independent entrants to be smaller in size than dependent entering agencies. This prediction is confirmed by the results. Table 3.9 points out that in terms of income and staff size independent advertising entrants are smaller than their dependent entering counterparts. While independent agencies enter the sample with an average size of almost 10 employees and 1.39 million Dutch guilders of gross income, diversified entrants display an average entry size of 22 employees and a mean gross income of 3.60 million guilders.

Hypothesis 4 , predicting a positive relationship between age and firm size, is also supported by the findings. Table 3.10 reveals that the average size of surviving entrants (independent and dependent agencies together) grows substantially over the time period. From an average size of 1.60 million Dutch guilders in the year of entry, the size has more than doubled by the end of 
the time period, to an average of 3.93 million Dutch guilders'.

Table 3. 10: Post-entry finm size

\begin{tabular}{|c|c|c|c|c|c|c|c|c|c|c|}
\hline $\begin{array}{l}\text { SIRE } \\
\text { (Wneone) }\end{array}$ & $t$ & $t+1$ & $t+2$ & $t+3$ & $t+4$ & $t+5$ & $1+6$ & $t+7$ & $1+8$ & $t+9$ \\
\hline Futrants & $\begin{array}{l}1.60 \\
(135)\end{array}$ & $\begin{array}{l}1.83 \\
(1.59)\end{array}$ & $\begin{array}{l}2.13 \\
(11.89)\end{array}$ & $\begin{array}{l}2: 60 \\
(243)\end{array}$ & $\begin{array}{l}260 \\
(2,46)\end{array}$ & $\begin{array}{l}2.86 \\
2.63)\end{array}$ & $\begin{array}{l}2.86 \\
(2.59)\end{array}$ & $\begin{array}{l}2.86 \\
(2.32)\end{array}$ & $\begin{array}{l}2.65 \\
2.44)\end{array}$ & $\begin{array}{l}3.93 \\
(4.22)\end{array}$ \\
\hline $\begin{array}{l}\text { Insumbents" } \\
\text { Mann }\end{array}$ & $\begin{array}{l}3.50 \\
(4.53)\end{array}$ & $\begin{array}{l}3.68 \\
(4.72)\end{array}$ & $\begin{array}{l}3.86 \\
(4.93)\end{array}$ & $\begin{array}{l}4.01 \\
(5.14)\end{array}$ & $\begin{array}{l}4.14 \\
(5,33)\end{array}$ & $\begin{array}{l}4.25 \\
(5.47)\end{array}$ & $\begin{array}{l}436 \\
(5.59)\end{array}$ & $\begin{array}{l}4.46 \\
(5.71)\end{array}$ & $\begin{array}{l}4.55 \\
(5.81)\end{array}$ & $\begin{array}{l}4.50 \\
(5.79)\end{array}$ \\
\hline Witliney $u^{3}$ & $.6000^{* * *}$ & $.000^{* * *}$ & (000)*:* * & .01014\% & . & $.030^{\text {th } *}$ & $.055 *$ & .164 & .03에 & 344 \\
\hline
\end{tabular}

'In millions of Dutch 1985 Cuilders. Wheang are shown with stundiad deviations batween pareathesis.

Incumbents refer to all agencies other thatm entrants.

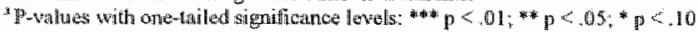

Entrants are, on average, significantly smaller compared to incumbents in the year of entry. However, relative to incumbents, their size slowly increases over time. By 149 , the average size of surviving entrants has about reached the average size of incumbents. In addition, the correlation matrix also shows a significant positive relationship between age and income $(.12 ; p<$ .01). Interestingly, plotting firm size against firm age reveals an inverted U-shaped relationship between the two variables (see Figure 3.6). Firm size first seems to increase with age and then declines as a firm gets older. The largest agencies in the industry are between thinty and forty years of age. Most younger agencies are, however, located in the left low corner of the plot, which reflects the finding that entrants are smaller in size compared to incumbents.

Three more observations concerning the outcomes are noteworthy. First, not only the average size of entrants, but also the average size of incumbents increases over time. Second, while the average size of entrants grows quit fast from $r+1$ until $+H 3$, the size remains stable until $t+8$ and then increases very strongly in 149 . The stability in average size in these years is probably the result of both the slow growth of surviving entrants (which is probably not only due to the business cycle effect as incumbents continue to show small increases in average size), and the possibility that those entrants exiting the data set between four and eight years after entry were not specifically smaller than those surviving this period. Finally, an interesting finding is that not only the mean size of entrants increases over the years, but so does the variation. Apparently, by 1994 a few 1985 entrants have succeded in becoming substantially

\footnotetext{
'Both independent and dependent agencies whose ownership data is available in the year of extry, increstat in she. Independent agencies about trippled their size after nine yeas; dependent entronts atmost doubled in size ninc years posssntry.
} 
larger than the average incumbent agency. In Chapters 4 through 7 the determinants of success and failure, only sideways up for discussion in the present chapter, will be addressed more thoroughly

Tigure 3.6: Income by firm age

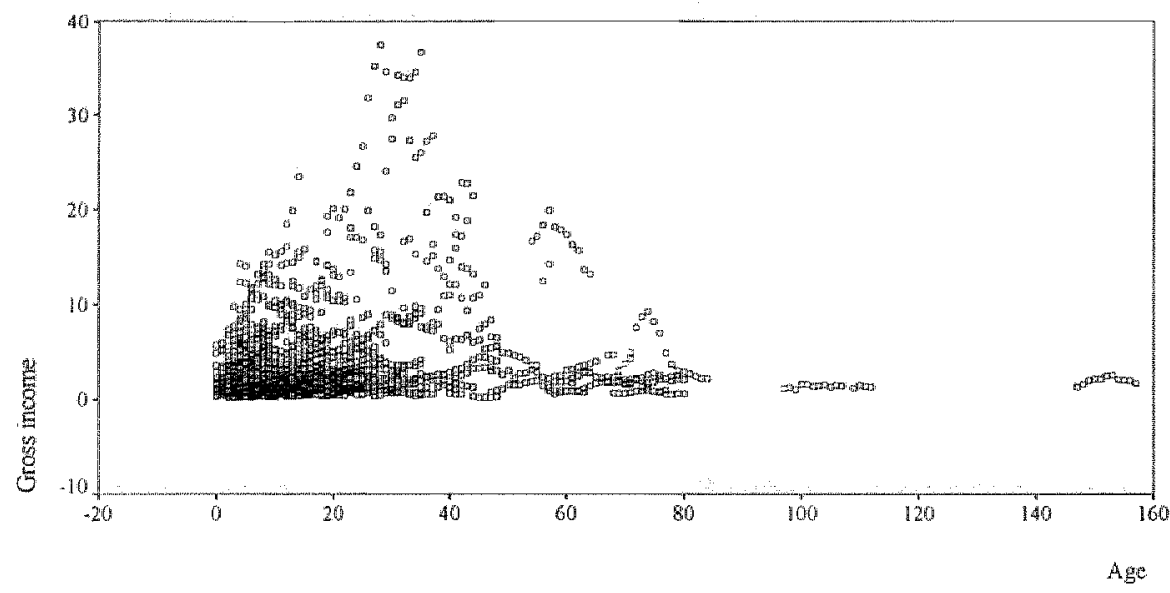

\subsubsection{Age and firm growth}

Hypothesis 5, which predicts a negative association between firm age and growth, is largely confirmed by the findings. Table 3.11 reveals that as agencies grow older (entrants and incumbents), their growth pace declines. Furthermore, during most of the investigated nine years after entry, the growth rate of newcomers is significantly above the average growth pace displayed by incumbents in these years. The mean income growth rate of incumbents exceeds the average growth rate of entrants only in $t+8$. The staff growth of incumbents is higher, $i, e$, less negative, than the pace of entrants nine years subsequent to entry only.

Between the groups of entrants the growth rates differ widely. In Table 3.12 it can be observed that the income growth of entrants varies from 44 percent for the 1985 entrants in the first post-entry year to only 4.15 percent for the 1992 entrants one year after entry. The mean growth pace of incumbents also shows the largest difference between these two years. Incumbents grew with almost 15 percent in terms of income in 1986 (sample without 1985 entrants in +1 ) and produced an average decrease in their income of -3.80 percent in 1993 compared to 1992 (sample without 1992 entrants in $t+1$ ). These figures clearly show that the eighties were a prospering period for the advertising industry, while the nineties started with an impressive crisis, having an effect on both incumbent and entering agencies. 
Table 3.11: Postentiry growth

\begin{tabular}{|c|c|c|c|c|c|c|c|c|c|c|}
\hline & $t$ & $t+1$ & $t+2$ & $t+3$ & $t+4$ & $t+5$ & $t+6$ & $t+7$ & $1+8$ & $1+9$ \\
\hline \multicolumn{11}{|c|}{ NOCOME GRONTH } \\
\hline Enirats & - & $\begin{array}{l}18.70 \\
(30.26)\end{array}$ & $\begin{array}{l}12.50 \\
(22.02)\end{array}$ & $\begin{array}{l}295 \\
(29.16)\end{array}$ & $\begin{array}{l}3.77 \\
18.20)\end{array}$ & $\begin{array}{l}193 \\
(14.44)\end{array}$ & $\begin{array}{l}-1.48 \\
(1501)\end{array}$ & $\begin{array}{l}3.10 \\
(13.83)\end{array}$ & $\begin{array}{l}613 \\
(1261)\end{array}$ & $\begin{array}{l}-1.37 \\
(14.77)\end{array}$ \\
\hline $\begin{array}{l}\text { Hecumbents } \\
\text { Marm* }\end{array}$ & - & $\frac{4.62}{(18.13)}$ & $\begin{array}{l}3.52 \\
(17.87)\end{array}$ & $\begin{array}{l}2.03 \\
(10.23)\end{array}$ & 87 & $\begin{array}{l}63 \\
(15.59)\end{array}$ & $\begin{array}{l}-1.80 \\
(15.03)\end{array}$ & $\begin{array}{l}3.95 \\
(14.26)\end{array}$ & $\frac{4.22}{(1437)}$ & $\begin{array}{l}-3,84 \\
(13,05)\end{array}$ \\
\hline Withney of & - & $.0000^{*}$ & $.0 \mathrm{fO}^{* * \mathrm{k}}$ & $.0000^{* 14}$ & $.081 *$ & $.073^{i *}$ & .496 & .001 wit in & 385 & 180 \\
\hline \multicolumn{11}{|c|}{ STAFF GROWTH } \\
\hline Funtrants & - & $\begin{array}{l}11.65 \\
(27.49)\end{array}$ & $\begin{array}{l}893 \\
(23.75)\end{array}$ & $\begin{array}{l}7.28 \\
(19.48)\end{array}$ & $\begin{array}{l}3.87 \\
(18.58)\end{array}$ & $\begin{array}{l}.37 \\
(14.02)\end{array}$ & $\begin{array}{l}66 \\
(1+28)\end{array}$ & $\begin{array}{l}37 \\
(15.91)\end{array}$ & $\begin{array}{l}-2.30 \\
(18.00)\end{array}$ & $\begin{array}{l}-6.42 \\
(6.711)\end{array}$ \\
\hline Incusnbents & - & $\begin{array}{l}2.89 \\
(18.31)\end{array}$ & $\begin{array}{l}1.83 \\
(17.49)\end{array}$ & $\begin{array}{l}1.02 \\
(17.43)\end{array}$ & $\begin{array}{l}418 \\
(16.47)\end{array}$ & $\begin{array}{l}.99 \\
16.68)\end{array}$ & $\begin{array}{l}2,02 \\
(16.42)\end{array}$ & $\begin{array}{l}-392 \\
(16.15)\end{array}$ & $\begin{array}{l}-4.73 \\
(16.76)\end{array}$ & $\begin{array}{l}-3.50 \\
(14.56)\end{array}$ \\
\hline $\begin{array}{l}\text { Marni- } \\
\text { Withnay U U" }\end{array}$ & - & $.0000^{-1=*}$ & $.0011^{* * *}$ & $.0000^{\text {and }}$ & W017 的 & .168 & .088 \% & .178 & .374 & .122 \\
\hline
\end{tabular}

"Means are shown with standard deviations between parenthesis.

"Incurvesents refer to all agencies ofher than entrants.

"P-waluess with one-tanted signilicance levels: *** $p<01, * * p<05 ; p<.10$

Table 3.12: Income growth of entrants and incumbents

\begin{tabular}{|c|c|c|c|c|c|c|c|c|c|}
\hline Entrants andi incumbents' & $t$ & $t+2$ & $t+3$ & $t+4$ & $t+5$ & $1+6$ & $t+7$ & $t+8$ & $t+9$ \\
\hline $\begin{array}{l}1985 \text { Entrunis } \\
\text { Incumbents }\end{array}$ & $\begin{array}{l}44.04 \\
14.96\end{array}$ & $\begin{array}{l}25.49 \\
13.28\end{array}$ & $\begin{array}{l}29.95 \\
14.28\end{array}$ & $\begin{array}{l}12.37 \\
10.95\end{array}$ & $\begin{array}{l}6.70 \\
7.76\end{array}$ & $\begin{array}{l}-4.90 \\
1.99\end{array}$ & $\begin{array}{l}4.51 \\
-.57\end{array}$ & $\begin{array}{l}-8.02 \\
-3.55\end{array}$ & $\begin{array}{l}-1.37 \\
.05\end{array}$ \\
\hline $\begin{array}{l}1986 \text { Entrants } \\
\text { Incumbents }\end{array}$ & $\begin{array}{l}17.444 \\
13.87\end{array}$ & $\begin{array}{l}16.33 \\
15.20\end{array}$ & $\begin{array}{l}13.1 \\
10.88\end{array}$ & $\begin{array}{l}3.87 \\
7.63\end{array}$ & $\begin{array}{l}.19 \\
1.75\end{array}$ & $\begin{array}{l}3.04 \\
-.51\end{array}$ & $\begin{array}{l}-.08 \\
-3.91\end{array}$ & $\begin{array}{l}4.43 \\
21\end{array}$ & \\
\hline $\begin{array}{l}1987 \text { Entrants } \\
\text { Incumbents }\end{array}$ & $\begin{array}{l}40.26 \\
12.38\end{array}$ & $\begin{array}{l}28.60 \\
9.19\end{array}$ & $\begin{array}{l}11.95 \\
7.28\end{array}$ & $\begin{array}{l}3.99 \\
1.44\end{array}$ & $\begin{array}{l}2.70 \\
-.58\end{array}$ & $\begin{array}{l}-5.34 \\
-3.59\end{array}$ & $\begin{array}{l}4.18 \\
-.36\end{array}$ & & \\
\hline $\begin{array}{l}\text { 1984 Entrants } \\
\text { Infumbents }\end{array}$ & $\begin{array}{l}28.62 \\
9.97\end{array}$ & $\begin{array}{l}12.19 \\
7.44\end{array}$ & $\begin{array}{l}1283 \\
1.09\end{array}$ & $\begin{array}{l}2.39 \\
-47\end{array}$ & $\begin{array}{l}.82 \\
-3.87\end{array}$ & $\begin{array}{l}3,84 \\
-17\end{array}$ & & & \\
\hline $\begin{array}{l}1989 \text { Fsilrants } \\
\text { Incumbents }\end{array}$ & $\begin{array}{l}15.44 \\
7.26\end{array}$ & $\begin{array}{l}5.67 \\
1.35\end{array}$ & $\begin{array}{l}-2.05 \\
-.23\end{array}$ & $\begin{array}{l}7.37 \\
-3.51\end{array}$ & $\begin{array}{l}.26 \\
-.61\end{array}$ & & & & \\
\hline 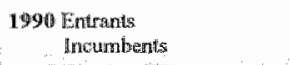 & $\begin{array}{l}13.28 \\
.33\end{array}$ & $\begin{array}{l}2.84 \\
-.55\end{array}$ & $\begin{array}{r}-6.16 \\
-3.56 \\
\end{array}$ & $\begin{array}{l}2.86 \\
-20\end{array}$ & & & & & \\
\hline $\begin{array}{l}1991 \text { Entrants } \\
\text { Lincumbestess }\end{array}$ & $\begin{array}{l}10.44 \\
-1.00\end{array}$ & $\begin{array}{l}8.95 \\
-4.42\end{array}$ & $\begin{array}{l}5.37 \\
.29\end{array}$ & & & & & & \\
\hline $\begin{array}{l}1992 \text { Entrants: } \\
\text { Bncurnthernes }\end{array}$ & $\begin{array}{l}4.15 \\
-3.80\end{array}$ & $\begin{array}{l}.97 \\
-.10\end{array}$ & & & & & & & \\
\hline $\begin{array}{l}1993 \text { sintrants } \\
\text { Incturylsents }\end{array}$ & $\begin{array}{l}7.34 \\
.30\end{array}$ & & & & & & & & \\
\hline Awertige growth andry cohorls & 10.90 & 12.63 & 9.30 & 3.85 & 181 & -85 & 2.87 & -6.23 & 1.37 \\
\hline Average growth incumbents & 6.02 & 5.17 & 4.21 & 2.6 .4 & $\|.0\|$ & .57 & -1.61 & -1.67 & 05 \\
\hline
\end{tabular}

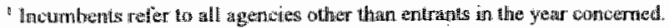


The analyses produce additional evidence for Hypothesis 5 , predicting that age and growth rates are negatively related. Table 3.12 points out that growth rates of entrants decline over time. In $t+1$ the average income growth rate of new establishments is almost 19 percent, while in $t+9$ it shows a negative sign, pointing to a decline of 1.37 percent. The table shows that the decreasing pattern holds for each entry cohort. Furthermore, also for incumbent agencies a similar growth pattern is observed. Again, these outcomes reveal that all advertising agencies were faced with the crisis in the begirining of the nineties, and that only in 1994 the growth rates started to recover somewhat. While the results seem to support the hypothesis, new establishments are significantly smaller compared to incumbents, and as age and size are related, it should be investigated whether the relationship between age and growth holds when controlling for" size. A simple OLS regression analysis with growth as the dependent variable and age and size (income) as the independent variables, over the whole data set, produces a significant negative association $(p<.01)$. Age and income growth are, thus, negatively related, irrespective of size. In addition, consistent with these findings, the same OLS regression. analysis over the whole sample using staff growth as the dependent variable, generates a significant, negative, relation $(\mathrm{p}<.01)$ too

Table 3. 11 further points out that the income and staff growth rates show a substantially larger variation among entrants compared to survivors in the first four years following entry. The initial years of existence are characterized by extremely high or low growth rates, which stabilize afterwards. This finding is in accordance with prior results (see, eng., Dunne and Hughes, 1994, and Jovanovic, 1982).

\subsubsection{Age and productivity}

Hypothesis 6 predicts a positive relationship between age and productivity. The analyses produce contradicting findings. Support for the hypothesis is provided by a significantly lower productivity level of entering agencies compared to incumbents (see Table 3.13). The difference remains significant until eight years after entry. Only nine years following entry the 1985 entrants have succeeded for the first time in obtaining, on average, the level of productivity of the average incumbent. However, the productivity level of newly entered firms does not increase steadily over time, which is inconsistent with the expectation.

Since incumbents are significantly larger in size compared to entering agencies, a simple OLS regression of productivity and age, controlling for size, is carried out over the whole sample, generating a significant negative relationship $(\mathrm{p}<01)$. Younger agencies are more productive than older advertising firms of the same size. Both among entrants and within the group of incumbents this negative relationship is reproduced. Table 3.7 and Table 3.8 plot productivity against firm age within the sample of entrants and incumbents, respectively. 
Table 3.13: Postentry productivity

\begin{tabular}{|c|c|c|c|c|c|c|c|c|c|c|}
\hline $\begin{array}{l}\text { PRODUC- } \\
\text { THYTY }{ }^{*}\end{array}$ & $t$ & $1+1$ & $t+2$ & $t \div 3$ & $t+4$ & $t+5$ & $t+6$ & $t+7$ & it +8 & $t+9$ \\
\hline Entrantus & $\frac{15}{(06)}$ & $\begin{array}{l}16 \\
(07)\end{array}$ & $\begin{array}{l}16 \\
(.08)\end{array}$ & $\begin{array}{l}16 \\
607)\end{array}$ & $\begin{array}{l}16 \\
(07)\end{array}$ & $\begin{array}{l}17 \\
(07)\end{array}$ & $\frac{15}{(05)}$ & $(06)$ & $\begin{array}{l}15 \\
(.07)\end{array}$ & $\begin{array}{l}18 \\
0.99\end{array}$ \\
\hline $\begin{array}{l}\text { Anourybens: } \\
\text { Manu- }\end{array}$ & $\begin{array}{l}.16 \\
6.081\end{array}$ & $\begin{array}{l}.17 \\
(06)\end{array}$ & $\begin{array}{l}.17 \\
(.06)\end{array}$ & $\begin{array}{l}17 \\
(.06)\end{array}$ & $\frac{17}{6.065}$ & $\begin{array}{l}17 \\
(006)\end{array}$ & $\frac{17}{(06)}$ & $\begin{array}{l}17 \\
(.06)\end{array}$ & $\begin{array}{l}18 \\
(06)\end{array}$ & $\begin{array}{l}.18 \\
(.06)\end{array}$ \\
\hline Withney $\mathrm{U}^{p}$ & $.0000^{\mathrm{k} * *}$ & $.010^{\mathrm{k} / \mathrm{*}}$ & $.018^{* *}$ & .0991. " & $.0111^{\text {* * }}$ & $.040^{* *}$ & , 组 & $+1040^{* * *}$ & $.0213^{* *}$ & 346 \\
\hline
\end{tabular}

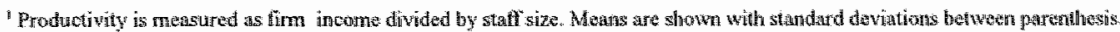

Irvoumbents refor to all agencies other than aturnis.

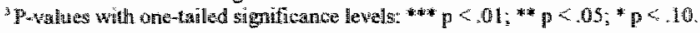

Figure 3.7: Productivity by age among incumbent firms

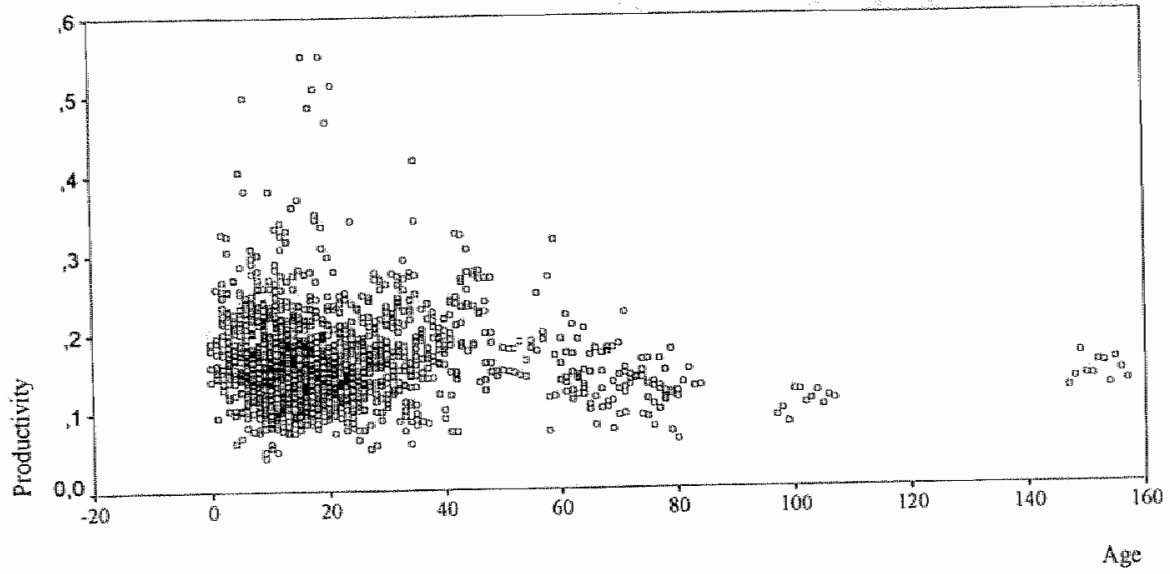

Figure 3.8: Productivity by age canong entrants

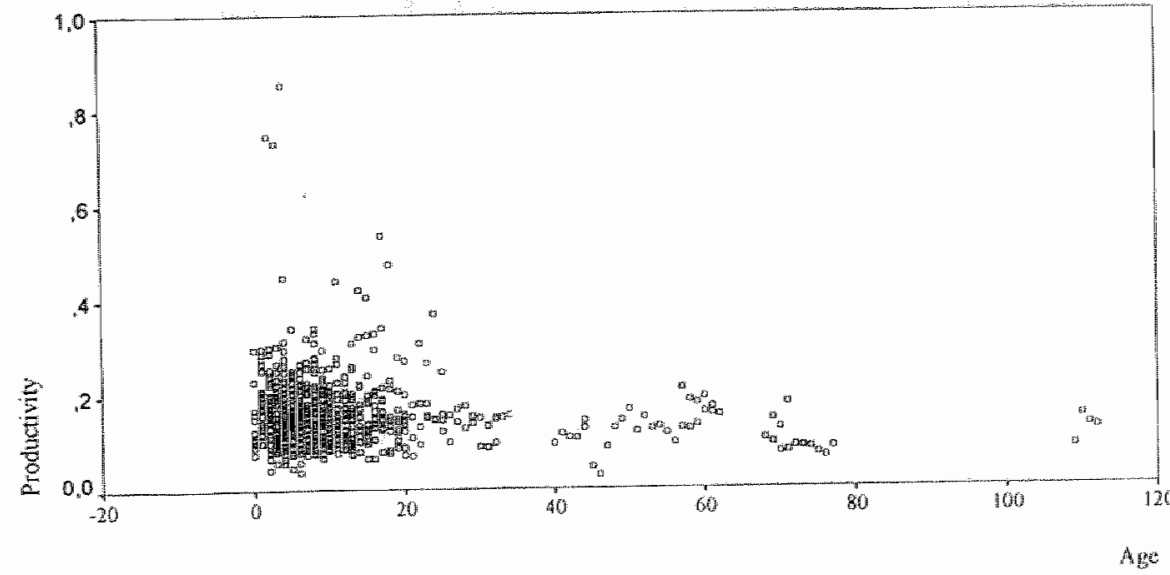


The plots reveal that among incumbents a number of young agencies is relatively efficient compared to agencies of the same age belonging to the group of entrants. And within the entrants group, a number of older agencies is included which have a relatively low productivity. Both observations underline the impact of the entry criteria applied in the present study, i.e., the criteria explain why the inefficient older firms belong to the entry group (because of their low productivity they achieved the financial criteria many years after founding only) and the efficient young companies to the incumbent firms.

\subsubsection{Size, growth and productivity}

Hypothesis 7 predicts a negative relationship between size and firm growth. Correlations and regression analyses over the whole sample provide support for this expectation. The correlations between size (income $\mathrm{i}_{\mathrm{i}-1}$ ) and income growth and staff growth are negative and significant $(-10$ and -.08 respectively, with $p<.01)$. Simple OLS regression analyses, controlling for age, produce sugnificant negative outcomes, too $(p<.01)$. Consistent with other samples, Gibrat's Law does not hold among Dutch advertising agencies: firm growth is negatively related to size.

Hypothesis 8, expecting a positive association between size and productivity, is also supported by the results. Size (income) and productivity are positively related $(40 ; p<.01)$. A simple OLS regression analysis, controlling for the effect of age, produces a significant and positive relationship too $(\mathrm{p}<01)$. Among Dutch advertising agencies, the larger firms are clearly the most productive.

\subsection{Pre-exit performance in the Dutch advertising industry}

\subsubsection{A comparison of the performance of swrwiving and failing agencies}

This seetion involves the performance of failing advertising agencies in the years preceding exit Hypotheses 9,11 and 12 , on the relationships of failure with size, growth and productivity are tested by comparing the performance of the three types of failing firms with the performance of surviving firms during the years preceding exit.

\subsubsection{F Fonlure ama average size}

Table 3.14 presents the average size of exiters during the years preceding failure. As mentioned in Section 3.4, the average size of exiters is rather small, apart from the merging agencies. This is confirmed by the results in Table 3.14. The findings reveal that advertising agencies that exit the sample because of bankruptcy or dissolution and because of insufficient data are indeed significantly smaller than surviving and merging agencies. The difference between surviving agencies and exiters with insufficient data persists until nine years preceding exit. 
Table 3.14: Pre-exitsize

\begin{tabular}{|c|c|c|c|c|c|c|c|c|c|}
\hline 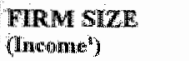 & $t-1$ & $f-z$ & $t-3$ & $t=4$ & $i-5$ & $t=6$ & +7 & $t-8$ & $t=9$ \\
\hline 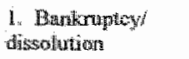 & $\begin{array}{l}1.94 \\
(1.48)\end{array}$ & $\begin{array}{l}2.19 \\
(1.91)\end{array}$ & $\begin{array}{l}2.34 \\
(1.98)\end{array}$ & $\begin{array}{l}2.45 \\
(1.69)\end{array}$ & $\begin{array}{l}256 \\
(1.86)\end{array}$ & $\begin{array}{l}2.49 \\
(2,14)\end{array}$ & $\begin{array}{l}2.20 \\
(1.80)\end{array}$ & $\begin{array}{l}2.19 \\
(1.61)\end{array}$ & $\begin{array}{l}2.66 \\
(2.12)\end{array}$ \\
\hline $\begin{array}{l}\text { 2. Muerger } \\
\text { acculaistion }\end{array}$ & $\begin{array}{l}4.22 \\
(4.52)\end{array}$ & $\begin{array}{l}4.35 \\
(4.96)\end{array}$ & $\begin{array}{l}4.57 \\
(5.78)\end{array}$ & $\begin{array}{l}4.91 \\
(5.44)\end{array}$ & $\begin{array}{l}4: 56 \\
(5,42)\end{array}$ & $\begin{array}{l}3.94 \\
(4.65)\end{array}$ & $\begin{array}{l}4.400 \\
(4.94)\end{array}$ & $\begin{array}{l}3.89 \\
(4,41)\end{array}$ & $\begin{array}{l}6.62 \\
(9.40)\end{array}$ \\
\hline 3. Insuritcient dolla & $\begin{array}{l}\text { (1) } \\
(1.12)\end{array}$ & $\begin{array}{l}1.37 \\
(.98)\end{array}$ & $\begin{array}{l}1.32 \\
(.96)\end{array}$ & $\begin{array}{l}1.24 \\
0.925\end{array}$ & $\begin{array}{l}1.08 \\
(.85)\end{array}$ & $\begin{array}{l}960 \\
801\end{array}$ & $\begin{array}{c}1.02 \\
0.74)\end{array}$ & $\frac{99}{(.72)}$ & $\begin{array}{l}90 \\
(x)\end{array}$ \\
\hline 4. Sunvinges ${ }^{2}$ & $\begin{array}{l}3.42 \\
(4.66)\end{array}$ & $\begin{array}{l}3.45 \\
(4.49)\end{array}$ & $\begin{array}{l}3.5 \% \\
(4.52)\end{array}$ & $\begin{array}{l}3.51 \\
(4.50)\end{array}$ & $\begin{array}{l}3.47 \\
(4.44)\end{array}$ & $\begin{array}{l}3.45 \\
(4.38)\end{array}$ & $\begin{array}{l}3.42 \\
(4.28)\end{array}$ & $\begin{array}{l}3.40 \\
(4,16)\end{array}$ & $\begin{array}{l}3.56 \\
(4,02)\end{array}$ \\
\hline 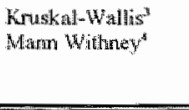 & 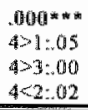 & $\begin{array}{l}000 \text { * } \\
4<2: 06 \\
4>3: 00\end{array}$ & 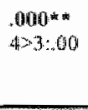 & $\begin{array}{l}n 000 * * * \\
4>3 ; 00\end{array}$ & $\begin{array}{l}.000 \% * 1 \% \\
4>3: 09\end{array}$ & $\begin{array}{l}040 * \text { सा } \\
4>3: 00\end{array}$ & $4>3,000$ & $\begin{array}{l}0122^{4} \\
4>3: 00\end{array}$ & $\begin{array}{l}4: 12 * \\
4>3<60\end{array}$ \\
\hline
\end{tabular}

In millitans of Dutcli 1985 Guilders.

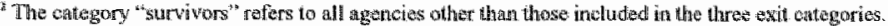

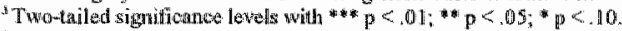

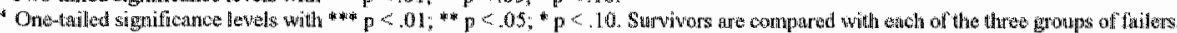

In addition, a correlation between size and exit, controlling for firm age, produces the expected negative relationship too. Hypothesis 9, predicting a negative relationship between current size and failure, are, thus, confirmed by the results. Agencies that disappear from the sample due to mergers or acquisitions appear to be larger, on average, than survivors. The difference is significant in $t-1$ and $t-2$. The average income figures displayed in Table 3.14 should not be interpreted as a pattern over time. The reason is that the average income of each category are, in each year prior to exit, based on a different number of agencies. This is the result of the fact that the number of years firms are included in the data set ranges from one to eleven. For the present table this implies that two extremes coexist: exiting firms that are included in the sample only for one year $(t-1)$, their income being used in the callculation of the average income in $1-1$ only, and exiting agencies being part of the sample for nine years $(t-1$ through $1-9)$, their revenues being included in the average income in each of these nine years.

The results provide no support for Hypothesis 10, expecting that independent entrants exit more often than diversifying entrants. Table 3.15 provides the results.

Table 3.15: Exit of entran categories

\begin{tabular}{|c|c|c|}
\hline Entrants & $\mathbf{N}$ & Prit (N) \\
\hline Independent agencies & 1000 & $22(22.00 \%)$ \\
\hline Dependent $t_{n}$ diversified agencies & 13 & $2(75.38 \% 8 \%)$ \\
\hline Fissher $r^{\prime}$ s Exavet & & 448 \\
\hline
\end{tabular}

While independent entering agencies outnumber diversifying entrants among exiters, the 
differences observed between the percentages of exiters among both groups are small. A Fisher's Exact test produces an insignificant relationship $(\mathrm{p}>10)$. A simple correlation between ownership status and exit generates a negative walue, too. Of the two entrant types, 22 and 15 percent respectively, disappeared from the data base before 1994. The findings show that, in contradiction to the prediction, an equal percentage of independent and dependent entering agencies disappeared from the data base before 1994.

\subsubsection{Failure and firm growth}

Table 3.16 provides the awerage growth rates of failing firms in the years preceding exit.

Table 3.16: Prewexit growth

\begin{tabular}{|c|c|c|c|c|c|c|c|c|c|}
\hline & $t-1$ & $t-2$ & $t-3$ & $t-4$ & $t-5$ & $t-6$ & $t-7$ & $t-8$ & $t-9$ \\
\hline \multicolumn{10}{|l|}{ INCOME GROWTH } \\
\hline $\begin{array}{l}\text { 1. Buinkrupteyf } \\
\text { disusolution }\end{array}$ & $\begin{array}{l}7.39 \\
(26.05)\end{array}$ & $\begin{array}{l}82 \\
(19.65)\end{array}$ & $\begin{array}{l}12.47 \\
(24.87)\end{array}$ & $\begin{array}{l}2.86 \\
(1568)\end{array}$ & $\begin{array}{l}17.77 \\
(26.98)\end{array}$ & $\begin{array}{l}5.32 \\
(18: 21)\end{array}$ & $\begin{array}{l}12.80 \\
(27.44)\end{array}$ & $\begin{array}{l}14.21 \\
(18.22)\end{array}$ & $\begin{array}{l}13.74 \\
(9.49)\end{array}$ \\
\hline 2. Mergarf acumbisition & $\begin{array}{l}7.38 \\
(19.31)\end{array}$ & $\begin{array}{l}2.05 \\
(23.68)\end{array}$ & $\begin{array}{l}25,87 \\
(47,53)\end{array}$ & $\begin{array}{l}6,63 \\
(13.87)\end{array}$ & $\begin{array}{l}10.83 \\
(9.92)\end{array}$ & $\begin{array}{l}11.89 \\
(25.35)\end{array}$ & $\begin{array}{l}21.81 \\
0.12 .979\end{array}$ & $\begin{array}{l}5.71 \\
(8.01)\end{array}$ & $\begin{array}{l}9.14 \\
(12.97)\end{array}$ \\
\hline 3. Insufficiant datak & $\begin{array}{l}1.03 \\
(24.77)\end{array}$ & $\begin{array}{l}6.00 \\
(23.05)\end{array}$ & $\begin{array}{l}20.80 \\
(44,41)\end{array}$ & $\begin{array}{l}8.76 \\
(15.66)\end{array}$ & $\begin{array}{l}18.67 \\
(25.57)\end{array}$ & $\begin{array}{l}12.21 \\
(13.21)\end{array}$ & $\begin{array}{l}1210 \\
(11.56)\end{array}$ & $\begin{array}{l}12.94 \\
(24.27)\end{array}$ & $\begin{array}{l}6.87 \\
(13.44)\end{array}$ \\
\hline 4. Surwiwors & $\begin{array}{l}729 \\
(21.66)\end{array}$ & $\begin{array}{l}8.34 \\
(22.35)\end{array}$ & $\begin{array}{l}9.49 \\
(21.19)\end{array}$ & $\begin{array}{l}11.14 \\
(21.41)\end{array}$ & $\begin{array}{l}12.50 \\
(21.64)\end{array}$ & $\begin{array}{l}13.50 \\
(22.69)\end{array}$ & $\begin{array}{l}14.15 \\
(22.89)\end{array}$ & $\begin{array}{l}13.62 \\
(22,81)\end{array}$ & $\begin{array}{l}12.90 \\
(20.48)\end{array}$ \\
\hline $\begin{array}{l}\text { Kruskal-Wull is } \\
\text { Marm Withor } \text { s. }^{3}\end{array}$ & .249 & 115 & 145 & .6018 & 8444 & .503 & .955 & .692 & .888 \\
\hline \multicolumn{10}{|l|}{ STAFT GROWTH } \\
\hline $\begin{array}{l}\text { 1. Bunkniptoy } \\
\text { dissolution }\end{array}$ & $\begin{array}{l}-8.47 \\
(20.44)\end{array}$ & $\begin{array}{l}8.77 \\
(30.16)\end{array}$ & $\begin{array}{l}469 \\
(18.11)\end{array}$ & $\begin{array}{l}4.54 \\
(25.71)\end{array}$ & $\begin{array}{l}5,07 \\
(10.10)\end{array}$ & $\begin{array}{l}1.2 .96 \\
(21.20)\end{array}$ & $\begin{array}{l}10.37 \\
(18.13)\end{array}$ & $\begin{array}{l}3.49 \\
(5.22)\end{array}$ & $(90$ \\
\hline 2. Merger actudation & $\begin{array}{l}-4.20 \\
(16.93)\end{array}$ & $\begin{array}{l}11.93 \\
(25,02)\end{array}$ & $\begin{array}{l}9.28 \\
(25.28)\end{array}$ & $\begin{array}{l}\$ .15 \\
(13.19)\end{array}$ & $\begin{array}{l}-17 \\
0.27)\end{array}$ & $\begin{array}{l}17,93 \\
(32,04)\end{array}$ & $\begin{array}{l}6.11 \\
(12.92)\end{array}$ & $\begin{array}{l}6.37 \\
(10.04)\end{array}$ & $(-9)$ \\
\hline 3. In:alientat datu & $\begin{array}{l}-10.97 \\
(18.10)\end{array}$ & $\begin{array}{l}4.11 \\
(17.15)\end{array}$ & $\begin{array}{l}11.07 \\
(2828)\end{array}$ & $\begin{array}{l}10.65 \\
(18.80)\end{array}$ & $\begin{array}{l}7.70 \\
(21.32)\end{array}$ & $\begin{array}{l}11.25 \\
(18.42)\end{array}$ & $\begin{array}{l}2.85 \\
(12.85)\end{array}$ & $\begin{array}{l}4.09 \\
(16,65)\end{array}$ & $\begin{array}{l}16.67 \\
(23.57)\end{array}$ \\
\hline 4. Surviwoms & $\begin{array}{l}4.63 \\
(19.32)\end{array}$ & $\begin{array}{l}4.84 \\
(19.64)\end{array}$ & $\begin{array}{l}5.64 \\
(19.52)\end{array}$ & $\begin{array}{l}6.71 \\
(18892)\end{array}$ & $\begin{array}{l}7.97 \\
(99.50)\end{array}$ & $\begin{array}{l}7.84 \\
(19.93)\end{array}$ & $\begin{array}{l}8.11 \\
(19.8010)\end{array}$ & $\begin{array}{l}8.10 \\
(19.63)\end{array}$ & $\begin{array}{l}6.77 \\
(17.52)\end{array}$ \\
\hline Kunskal-Mullis ${ }^{2}$ & 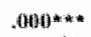 & .842 & .570 & .355 & .635 & .454 & .781 & .964 & $.79 !$ \\
\hline Mamin WathnoyUs & $\begin{array}{l}4>11,01 \\
452 ; 01 \\
4>3,00\end{array}$ & nws & $3>-4: .09$ & $3>4: 06$ & ns & $234: 08$ & mis & as & nes \\
\hline
\end{tabular}

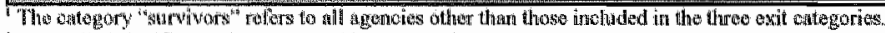

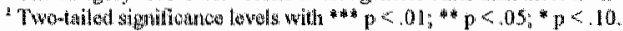

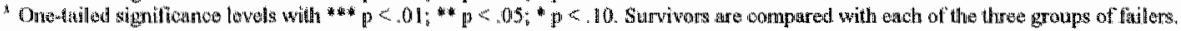

Hypothesis 11 , expecting a negative relationship between exit and firm growth, is only weakly supported by the results. With respect to income growth, none of the categories of exiters shows a clear declining pattern in their growth rates in the years preceding failure. Furthermore, the only negative average income growth is reported for bankrupts and dissoluted 
agencies two years preceding exit. Only few significant differences in income growth are observed between surviving and exting advertising agencies (see Table 3.16). Significant discrepancies, in the expected direction, only exist between agencies exiting the data base because of insufficient data and survivors in $t-1$, and between bankrupt/dissoluted agencies and survivors in $t-2$. A partial correlation, between exit and income growth in $k 1$, controlling for firm size and firm age, is conducted as well: The analysis produces, in accordance with the results in the table, a negative and almost significant outcome. During the years $t-3$ through $t-$ 9, the income growth of the groups of exiting firms varies relative to the survivors" income growth, sometimes being higher than the growth rate of the surviving companies. Three years before exit the growth rate of merging agencies is significantly above the growth rate of surviving advertising firms $(p<.05)$.

An interesting finding is the substantial fluctuation in the income growth rates among the three groups of exiting agencies over the years $t-1$ through $t-9$ compared to the rates of growth among surviving agencies. The pre-exit period of advertising firms seems to be characterized by an uncertain income growth rate. Especially for small organizations, fluctuations in income growth may be (partly) responsible for exit. Since small agencies have few clients, the loss and acquisition of one of them has a severe impact on their performance.

A next remarkable outcome is the large standard deviation in the income growth among exiting agencies. Apparently, a considerable number of firms obtained either a relatively high or low income growth in the years preceding exit. The ranking nethod applied in this section for comparing means does not take account of extreme values, but since surviving companies also display substantial standard deviations, the results of the analyses are unlikely to have been affected by the method.

The results with respect to pre-exit staff growth provide somewhat stronger evidence for Hypothesis 11. While there is, as was the case with income growth, no clear declining pattern in staff growth in the years preceding exit, contrary to income growth, all groups of exiters display a negative average staff growth one year preceding exit. Moreover, the growth rates of failers in $t-1$ are all significantly lower than the average staff growth obtained by surviving agencies in the same year $(\mathrm{p}<.05)$. A partial correlation between the staff growth of exiters in $t-1$ and all other observations of staff growth, controlling for firm size and firm age, produces a significant and negative value too $(\mathrm{p}<01)$. During the years $t-2$ through $t-9$, the average staff growths of the groups of exiting agencies are, newer again, significantly lower than the average staff growth of survivors. To the contrary, in some years failers show a higher growth rate than their surviving counterparts. Similar to the results observed for income growth, the average staff growth of the groups of exiters fluctuated more during the pre-exit years than did the average staff growth of surviving agencies. 


\subsubsection{Failure and productivity}

The results provide support for Hypothesis 12, expecting a negative relationship between fallure and productivity (see Table 3.17). In the years $t-2$ through $t-9$, the bankrupt and dissoluted firms as well as the agencies exiting because of insufficient data were, on average, less productive than survining firms. The differences are significant two and three years preceding exit for the bankrupt and dissoluted agencies and in $t-2$ until $1-6$ for the so-called insufficient data exiters". The last year before exit; the average productivity level of bankrupt/dissoluted agencies is lower, though insignificantly so, than the level of surviving agenctes. In the same year, merging and acquired agencies and 'insufficient data exiters' show a higher productivity level compared to survivors, though the difference is only significant for the former category. Since exiting firms are smaller and younger, on average, than survivors, and because it was reported above that productivity is positively linked to firm size and negatively to firm age, a partiall correlation is carried out between exit and productivity over the whole period, controlling for size and age. The analysis produces the expected negative significant outcome $(p<01)$. Exiting agencies have significantly lower productivity levels in the years preceding the event than surviving firms in the same years.

Interestingly, the productivity level of merging and acquired agencies appears to be relatively high compared to all other categories of agencies during the whole time period. The differences between mergers and survivors are significant in $\mathrm{t}-1$ and $\mathrm{t}-\mathrm{7}$.

Table 3.17: Pre-exir productivity

\begin{tabular}{|c|c|c|c|c|c|c|c|c|c|}
\hline PRODUCTIVITY" & $t-1$ & $t-2$ & $t-3$ & $t-4$ & $t-5$ & $1-6$ & $t-7$ & $t-8$ & $t-9$ \\
\hline $\begin{array}{l}\text { 1. Bank knploy/ disso- } \\
\text { linton }\end{array}$ & $.05)$ & .02 & $(1.4)$ & $\begin{array}{l}.14 \\
6.04)\end{array}$ & $\begin{array}{l}15 \\
(04)\end{array}$ & 14 & $\begin{array}{l}.14 \\
(04)\end{array}$ & $\begin{array}{l}.15 \\
(.04)\end{array}$ & $\begin{array}{l}.15 \\
(.04)\end{array}$ \\
\hline 2. Merger/açuisit:on & $\begin{array}{l}.18 \\
(.05)\end{array}$ & $\frac{.166}{(09)}$ & $\begin{array}{l}.17 \\
(.07)\end{array}$ & $\begin{array}{l}.17 \\
(04)\end{array}$ & $\begin{array}{l}.17 \\
(05)\end{array}$ & $\begin{array}{l}16 \\
609)\end{array}$ & $\frac{18}{(0+4)}$ & $\begin{array}{l}.17 \\
(.02)\end{array}$ & $\begin{array}{l}.17 \\
(.02)\end{array}$ \\
\hline 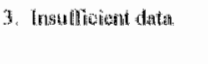 & .17 & 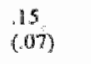 & $\begin{array}{l}.15 \\
(.06)\end{array}$ & .144 & $\begin{array}{l}144 \\
(.95)\end{array}$ & $\begin{array}{l}13 \\
(0,05)\end{array}$ & $\begin{array}{l}16 \\
(06)\end{array}$ & $\begin{array}{l}15 \\
(05)\end{array}$ & $\begin{array}{l}13 \\
.05)\end{array}$ \\
\hline 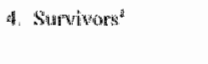 & $\begin{array}{l}.6 \\
(06)\end{array}$ & $\begin{array}{l}.166 \\
(.06)\end{array}$ & $\begin{array}{l}.16 \\
(06)\end{array}$ & $\begin{array}{l}.16 \\
(06)\end{array}$ & $\begin{array}{l}.16 \\
.065)\end{array}$ & $\begin{array}{l}16 \\
(06)\end{array}$ & $\frac{16}{(06)}$ & $\begin{array}{l}16 \\
(06)\end{array}$ & $\begin{array}{l}.16 \\
(.06)\end{array}$ \\
\hline 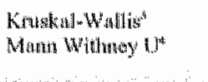 & $\begin{array}{l}109 \\
2>1: 09 \\
2>4: 02\end{array}$ & 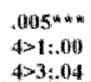 & $\begin{array}{l}4081^{\mathrm{ir}} \\
4>1: 05 \\
4 \times 3 \times 04\end{array}$ & $\begin{array}{l}.041 \text { in } \\
4>1: 1: 10 \\
4>3: 011\end{array}$ & $\begin{array}{l}02,4^{* * *} \\
4>3:, 01\end{array}$ & $\begin{array}{l}416 * * \\
4>1: 09 \\
4>3 ; .00\end{array}$ & $\begin{array}{l}430 \\
2>40.08\end{array}$ & .609 & $\begin{array}{l}.384 \\
4>3: 10\end{array}$ \\
\hline
\end{tabular}

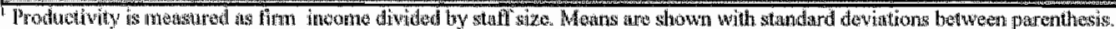

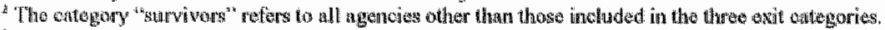

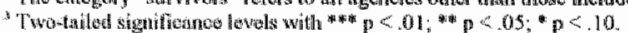

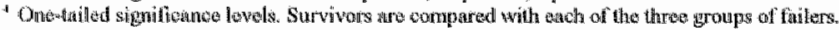

\subsubsection{A matched-pair analysis}

This section presents the results of the matched-pair analysis of the pre-exit performance of failing and surviving advertising agencies. As indicated earlier, this design controls for alterna- 
tive explanatory variables in the relationship between firm growth and exit and productivity and exit, such as firm size, age and ownership status.

\subsubsection{Faihre and firm growth}

Hypotheses 11 , predicting a lower growth rate of failers compared to survivors is generally, confirmed by the results. Over the whole period under study, all comparisons between income growth and staff growth of survivors and failing agencies are in the expected direction, though not always significant. The analyses for the separate years, on the other hand, do not always produce the expected outcomes. The results are summarized in Table 3.18 and 3.19

Failing entroms show a significantly lower income growth compared to their surviving counterparts in $t-2$ and $t-3$, and a significantly lower staff growth in $t-1$ and $t-2$. Surprisingly, in the last year before exit, the income growth of surviving entrants shows an even stronger decline than the income growth observed for failers.

Table 3.18: Matched-pair analysis on pre-exit growth of entraws'

\begin{tabular}{|c|c|c|c|c|c|c|}
\hline & Whole period & $t-1$ & $t-2$ & $t-3$ & $t-4$ & $1-5$ \\
\hline $\begin{array}{l}\text { INCOME GROWTH } \\
\text { Fatilens } \\
\text { Survivors } \\
\text { Wilcowon' } \\
\text { Patirs }\end{array}$ & $\begin{array}{l}7.91 \\
(21.28) \\
9.75 \\
(21.96) \\
.205 \\
47\end{array}$ & $\begin{array}{l}-3.29 \\
(18.72) \\
-8.68 \\
(12.64) \\
199 \\
10\end{array}$ & $\begin{array}{l}-3.15 \\
(13.92) \\
12.09 \\
(27.20) \\
.087 * \\
10\end{array}$ & $\begin{array}{l}3.53 \\
(12.36) \\
11.1 .3 \\
(1.488) \\
.0199^{4} \\
10\end{array}$ & $\begin{array}{l}20.03 \\
(20.86) \\
18.39 \\
(23.17) \\
22.1 \\
9\end{array}$ & $\begin{array}{l}23.66 \\
(24.72) \\
16.29 \\
(23.55) \\
390 \\
8\end{array}$ \\
\hline $\begin{array}{l}\text { STAFI GROWTH } \\
\text { Failers } \\
\text { Survivors } \\
\text { Wilcowon: } \\
\text { Pairs }\end{array}$ & $\begin{array}{l}1.83 \\
(18.11) \\
16.54 \\
(27.354 \\
0004 \\
47\end{array}$ & $\begin{array}{l}-16.54 \\
(18.89) \\
13.29 \\
(18.95) \\
011.4 \\
10\end{array}$ & $\begin{array}{l}-.71 \\
(7.66) \\
2.07 \\
(21.86) \\
.384 \\
10 \\
\end{array}$ & $\begin{array}{l}7.91 \\
(17.44) \\
14.69 \\
(16.89) \\
221 \\
10 \\
\end{array}$ & $\begin{array}{l}8.52 \\
(15.87) \\
22.97 \\
(37.54) \\
173 \\
2 \\
\end{array}$ & $\begin{array}{l}12.83 \\
(14.23) \\
31.14 \\
(32.68) \\
119 \\
0\end{array}$ \\
\hline
\end{tabular}

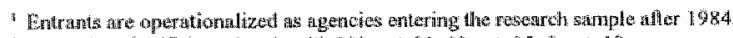

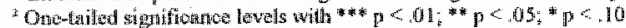

Furthermore, the gross income and staff growth of the failing entrants both have a negative sign one and two years before exit. Finally, from $1-5$ through $t-1$, both the staff and income growth pace of exiting entrants clearly shows a declining pattern.

For each analysis of matched pairs of incumbent agencies, similar patterns of results emerge. Many outcomes are in the predicted direction. Failers show lower growth rates than survivors. Significant differences in income growth between exiters and survivors, in favor of the latter agencies, are observed for the pairs of exiters with insufficient data in $1-2$ and $1-4$ and for the pairs of bankrupt/dissoluted agencies in $t-6$ and $1-8$. Significant staff growth differences in the predicted direction are reported for the pairs of bankrupt/dissoluted agencies in $t-5$, for the pairs of exiters with insufficient data in $t-1$ and, finally, for the pairs of 
merging/acquired agencies in $t-1$ and $1-4$. Furtherinore, negative income growth rates are observed for all exit modes in $t-1$ and $1-2$ (apart from the mergers in $(-1)$, and a negative staff growth is reported for all groups of fallers in $t-1$. However, survivors sometimes also display negative growth rates in these years. Apparently, the years under study were difficult for most atgencies.

Table 3.19: Marched-pair analysis on pre-exit growth of incumbents

\begin{tabular}{|c|c|c|c|c|c|c|c|c|c|}
\hline & $\begin{array}{l}\text { Whole } \\
\text { period }\end{array}$ & $t-1$ & $t-2$ & $t \cdot 3$ & $t-4$ & $t-5$ & $t-6$ & $t-7$ & $t-1$ \\
\hline 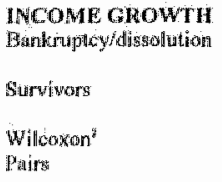 & $\begin{array}{l}3.91 \\
(19.19) \\
11.08 \\
(15.21) \\
0.11 \% \\
64\end{array}$ & $\begin{array}{l}423 \\
(15.14) \\
-3.42 \\
(4.78) \\
.3901 \\
8\end{array}$ & $\begin{array}{l}4.31 \\
16.23) \\
-14 \\
(12.17) \\
306 \\
8\end{array}$ & $\begin{array}{l}12.89 \\
(18.99) \\
12.04 \\
(15.10) \\
337 \\
8\end{array}$ & $\begin{array}{l}-2.26 \\
(15.9) \\
10.2 \% \\
(10.20) \\
163 \\
8\end{array}$ & $\begin{array}{l}13.09 \\
(29.22) \\
20.84 \\
(17.46) \\
242 \\
8\end{array}$ & $\begin{array}{l}2.69 \\
(17.74) \\
18.64 \\
(12.62) \\
.022 * \\
8\end{array}$ & $\begin{array}{l}3.83 \\
(21.31) \\
16.67 \\
(20.64) \\
104^{*} \\
8\end{array}$ & $\begin{array}{l}9.60 \\
(1.2 .70) \\
1.31 \\
(9.21) \\
.018 * \\
8\end{array}$ \\
\hline $\begin{array}{l}\text { Inawficient datia } \\
\text { Surviwors } \\
\text { Wilcoxon } \\
\text { Pairs: }\end{array}$ & $\begin{array}{l}5.60 \\
(16.87) \\
9.32 \\
(19.41) \\
0(060 * \\
94\end{array}$ & $\begin{array}{l}-1.29 \\
(15.08) \\
5.28 \\
(22.969) \\
476 \\
12\end{array}$ & $\begin{array}{l}-5.99 \\
(25.61) \\
1.71 \\
(10.76) \\
0.58 \mathrm{~m} \\
12\end{array}$ & $\begin{array}{l}12.90 \\
(22.71) \\
4.60 \\
(17.79) \\
212 \\
12\end{array}$ & $\begin{array}{l}5.69 \\
(12.76) \\
21.49 \\
(24.12) \\
004^{* * \ldots} \\
12\end{array}$ & $\begin{array}{l}4.96 \\
(5.27) \\
10.30 \\
(12.11) \\
164 \\
12\end{array}$ & $\begin{array}{l}13.50 \\
(11.89) \\
9.40 \\
(26.01) \\
240 \\
12\end{array}$ & $\begin{array}{l}10.80 \\
(12.06) \\
11.53 \\
(19.87) \\
407 \\
12\end{array}$ & $\begin{array}{l}4.98 \\
(15.22) \\
10.45 \\
(13.54) \\
.222 \\
10\end{array}$ \\
\hline 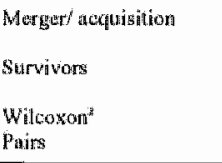 & $\begin{array}{l}6.30 \\
(18.50) \\
7.90 \\
(16.86) \\
467 \\
60\end{array}$ & $\begin{array}{l}(25.05) \\
2.06 \\
(17.47) \\
164 \\
8\end{array}$ & $\begin{array}{l}-8.40 \\
(25.07) \\
-1.33 \\
(16.61) \\
377 \\
8\end{array}$ & $\begin{array}{l}17.22 \\
(15.27) \\
1.37 \\
(10.48) \\
.025^{\star 4} \\
8\end{array}$ & $\begin{array}{l}09 \\
(12.46) \\
3.33 \\
(12.88) \\
.164 \\
8\end{array}$ & $\begin{array}{l}12.52 \\
(9.72) \\
13.27 \\
(22.17) \\
306 \\
7\end{array}$ & $\begin{array}{l}6.11 \\
(19.04) \\
13.53 \\
(9.33) \\
104 \\
8\end{array}$ & $\begin{array}{l}10.63 \\
(16.39) \\
18.80 \\
(1592) \\
242 \\
8\end{array}$ & $\begin{array}{l}4.02 \\
(7.68) \\
14.74 \\
(22.98) \\
.446 \\
5\end{array}$ \\
\hline 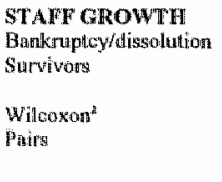 & $\begin{array}{l}4.65 \\
(21.47) \\
7.38 \\
(14.84) \\
127 \\
62\end{array}$ & $\begin{array}{l}-4.21 \\
(20.13) \\
-6,40 \\
(12.31) \\
.337 \\
8\end{array}$ & $\begin{array}{l}8.27 \\
(39.13) \\
1.55 \\
(7.71) \\
500 \\
6\end{array}$ & $\begin{array}{l}3.83 \\
(14.73) \\
1.56 \\
(12.55) \\
28.8 \\
8\end{array}$ & $\begin{array}{l}7.47 \\
(31.72) \\
13.81 \\
(10.86) \\
337 \\
8\end{array}$ & $\begin{array}{l}1.42 \\
(8.31) \\
19.07 \\
(17.47) \\
.014 * * \\
8\end{array}$ & $\begin{array}{l}10.33 \\
(18.86) \\
11.91 \\
(15.38) \\
445 \\
8\end{array}$ & $\begin{array}{l}6.35 \\
(15,54) \\
12,13 \\
(12.89) \\
232 \\
8\end{array}$ & $\begin{array}{l}3.49 \\
(5.92) \\
8.89 \\
(13.11) \\
.233 \\
6\end{array}$ \\
\hline 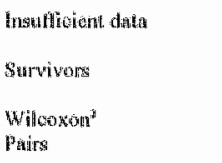 & $\begin{array}{l}4.75 \\
(20.99) \\
8.35 \\
(24.76) \\
166 \\
87\end{array}$ & $\begin{array}{l}-15.20 \\
(15.809) \\
.09 \\
(31.289) \\
.069^{* 4} \\
12\end{array}$ & $\begin{array}{l}2.29 \\
(14.95) \\
1.5 .48 \\
(36.10) \\
1.79 \\
12\end{array}$ & $\begin{array}{l}15.66 \\
(30.05) \\
12.60 \\
(17.46) \\
459 \\
12\end{array}$ & $\begin{array}{l}8.74 \\
(17.55) \\
5.99 \\
(22.09) \\
3.15 \\
12\end{array}$ & $\begin{array}{l}10.91 \\
(19.33) \\
10.52 \\
(18.35) \\
184 \\
12\end{array}$ & $\begin{array}{l}8.64 \\
(16.45) \\
2.64 \\
(19.00) \\
136 \\
112\end{array}$ & $\begin{array}{l}1.67 \\
(14.56) \\
700 \\
(24.52) \\
265 \\
10\end{array}$ & $\begin{array}{l}5.45 \\
(19.47) \\
16.20 \\
(27.91) \\
173 \\
6\end{array}$ \\
\hline 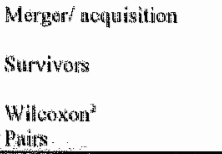 & $\begin{array}{l}2.40 \\
(15.37) \\
3.80 \\
(1470) \\
476 \\
55\end{array}$ & $\begin{array}{l}-8.30 \\
(11.24) \\
8.40 \\
(12.42) \\
.014 \\
8\end{array}$ & $\begin{array}{l}6.71 \\
(22.19) \\
-1.23 \\
(17.25) \\
250 \\
8\end{array}$ & $\begin{array}{l}3.10 \\
9.76) \\
-1.04 \\
(13.64) \\
232 \\
8\end{array}$ & $\begin{array}{l}2.11 \\
(10.26) \\
9.48 \\
(18.11) \\
.088 .8 \\
8\end{array}$ & $\begin{array}{l}-2.06 \\
(10.60) \\
-1.78 \\
(4.74) \\
398 \\
7\end{array}$ & $\begin{array}{l}7.67 \\
(23.03) \\
3.95 \\
(13.73) \\
.773 \\
8\end{array}$ & $\begin{array}{l}7.34 \\
(14.05) \\
6,60 \\
(2497) \\
446 \\
5\end{array}$ & $\begin{array}{l}4.02 \\
(7.68) \\
-.89 \\
(1.54) \\
159 \\
3\end{array}$ \\
\hline
\end{tabular}

'Inowatbent finns aro agencios that are in the sample in 1984

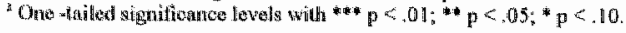

A significant result, contradicting the hypothesis, is found between mergers and survivors for income growth in $t-3$. Furthermore, in $t-2$, the staff growth of bankruptcies appears to be 
rather high; however, so is the variation: one of the failing agencies experienced a growth of 100 percent in that year. A steady decline in the growth of bankrupt and insufficient data exiters' begins about three years prior to exit. Before that time, the average growth rates show much variation: Merging agencies do not display a declining pattern in their growth rates before exit.

Similar to the findings in Subsection 3.6.1 on the pre-exit performance of agencies, a large variation in the growth rates of both failers and survivors is observed. Apparently, rather extreme growth rates are obtained both by failers and by exiters in the years preceding exit. Since many agencies are small, the applied measure of growth easily produces extreme values.

\subsubsection{Failure and productivity}

Hypothesis 12, expecting a negative association between exit and productivity, is also largely supported by the results. The results of the matched-pair analyses for entrants and incumbents are presented in Table 3.20 and Table 3.21 , respectively. Both tables show that, apart form the merging incumbent pairs, over the whole period, all other groups of failers display a significantly lower productivity level than their surviving counterparts. The differences remain significant for entrants in $t-2$ through $t-5$, for bankrupt/dissoluted incumbent pairs in $t-6$ and for insufficient data incumbent pairs in $t-1$ until $t-4$ and in $t-6$. The results on productivity for the merged and acquired incumbent agencies diverge quit strongly from the findings reported for the other pairs of incumbents. Interestingly, merging agencies show a significantly higher level of productivity compared to their surviving counterparts. The differences are significant over the whole period as well as in all but one of the eight years prior to exit. Their high efficiency level apparently made these agencies attractive candidates for take-over or merger.

The outcomes of the matched-pair analyses strongly concorde with the results obtained by means of the comparison between all failers and survivors, which points to their robustness.

Table 3.20: Matched-pair analysis on pre-exit productivity of entrants

\begin{tabular}{|c|c|c|c|c|c|c|}
\hline PRODUCTIVITY" & Whote period & $t-1$ & $t \cdot 2$ & $t-3$ & $r-4$ & $t-5$ \\
\hline \multirow[t]{2}{*}{ Fitalers. } & 14 & .15 & .14 & 14 & .14 & .13 \\
\hline & $(04)$ & $(.05)$ & $(04)$ & (0.04) & (64) & $(04)$ \\
\hline \multirow[t]{2}{*}{ Starvitors } & .17 & .15 & .19 & .17 & 17 & .18 \\
\hline & $(05)$ & $(04)$ & $(.08)$ & $(64)$ & $(05)$ & $(.04)$ \\
\hline Wilcoxon ${ }^{2}$ & $.0000^{\text {mat }}$ - & .500 & .029 \%"n & $014 \div$ & $.047 * *$ & $0113 \times$ \\
\hline Pairss & 50 & 10 & 10 & 10 & 10 & 10 \\
\hline
\end{tabular}

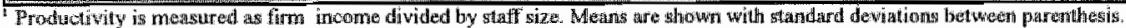

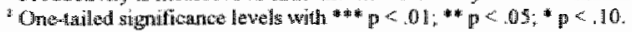


Table 3.21: Matched-pair analysis on pre-exil productivity of incumbents

\begin{tabular}{|c|c|c|c|c|c|c|c|c|c|}
\hline HLOLCTIVITY & $\begin{array}{l}\text { Whole } \\
\text { period }\end{array}$ & $t-1$ & $t-2$ & $t-3$ & $1-4$ & $t-5$ & $t-6$ & $t-7$ & $t-8$ \\
\hline Bankruptey/disisolution in & 10 & $\begin{array}{l}15 \\
6069\end{array}$ & $\begin{array}{l}.15 \\
(.05)\end{array}$ & $\begin{array}{l}16 \\
160\end{array}$ & $(04)$ & $\begin{array}{l}15 \\
(.04)\end{array}$ & (14) & $\begin{array}{l}15 \\
0.037\end{array}$ & $\begin{array}{l}.16 \\
(041)\end{array}$ \\
\hline surviwors & $\begin{array}{l}16 \\
(0.4)\end{array}$ & $\begin{array}{l}.17 \\
(0.05)\end{array}$ & $\begin{array}{l}16 \\
(.03)\end{array}$ & $\begin{array}{l}16 \\
(02)\end{array}$ & $\begin{array}{l}.14 \\
(02)\end{array}$ & $\begin{array}{l}.15 \\
(.02)\end{array}$ & $\begin{array}{l}17 \\
(04)\end{array}$ & $\begin{array}{l}16 \\
(04)\end{array}$ & $\begin{array}{l}16 \\
(.05)\end{array}$ \\
\hline Witcoxon & $20477^{14 *}$ & 135 & 277 & .412 & 250 & .338 & (120** & .199 & .466 \\
\hline Paupris & 653 & 8 & 8 & 8 & 8 & 7 & 8 & 8 & 8 \\
\hline 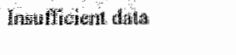 & $\begin{array}{l}15 \\
(06)\end{array}$ & $\begin{array}{l}15 \\
(06)\end{array}$ & $\begin{array}{l}.13 \\
.05)\end{array}$ & $\begin{array}{l}14 \\
(06)\end{array}$ & $\begin{array}{l}15 \\
(.07)\end{array}$ & $\begin{array}{l}15 \\
(06)\end{array}$ & $\begin{array}{l}15 \\
(.05)\end{array}$ & $\begin{array}{l}.16 \\
07\end{array}$ & $\begin{array}{l}.15 \\
(05)\end{array}$ \\
\hline Sturvivores & $\begin{array}{l}18 \\
0.07)\end{array}$ & 198 & $\begin{array}{l}17 \\
(05)\end{array}$ & $\begin{array}{l}10 \\
(06)\end{array}$ & $\begin{array}{l}21 \\
(.07)\end{array}$ & $\begin{array}{l}18 \\
(05)\end{array}$ & $\begin{array}{l}18 \\
(09)\end{array}$ & $\begin{array}{l}18 \\
(10)\end{array}$ & $\begin{array}{l}.15 \\
.05\end{array}$ \\
\hline Wilcoson & $.000^{* * * *}$ & $0446^{* * *}$ & $.00 G^{m * *}$ & .058: & $013^{\text {t-k }}$ & .107 & $058^{\prime \prime \prime}$ & 469 & 166 \\
\hline Deturs & 94 & 12 & 12 & 12 & 12 & 12 & 12 & 12 & 10 \\
\hline Merger acumisition & $\begin{array}{l}19 \\
(05)\end{array}$ & $\begin{array}{l}.22 \\
.0051\end{array}$ & $\begin{array}{l}19 \\
107\end{array}$ & .23 & $\begin{array}{l}20 \\
(04)\end{array}$ & $\begin{array}{l}20 \\
(04)\end{array}$ & $\begin{array}{l}17 \\
(04)\end{array}$ & $\begin{array}{l}1 \mathrm{~S} \\
(04)\end{array}$ & .17 \\
\hline Starvivers & $\begin{array}{l}16 \\
(04)\end{array}$ & $\begin{array}{l}16 \\
(64)\end{array}$ & $\begin{array}{l}17 \\
(.05)\end{array}$ & $\begin{array}{l}.16 \\
(.03)\end{array}$ & 16 & $\begin{array}{l}17 \\
102)\end{array}$ & $\begin{array}{l}15 \\
\text { (.03) }\end{array}$ & $\begin{array}{l}14 \\
(04)\end{array}$ & $\begin{array}{l}13 \\
.03 y\end{array}$ \\
\hline Wheoron & $.0000^{m}$ & $0006^{* 4}$ & 306 & (01) & $934 *$ & $00106 \cdots$ & $0006^{*}$ क क & $.046 *$ & $.022 * 0$ \\
\hline Pairis & 60 & 8 & 7 & 8 & 8 & 8 & 8 & 8 & 5 \\
\hline
\end{tabular}

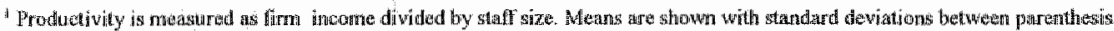

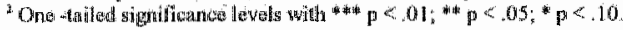

\subsection{Discussion}

Table 3.22 provides a summary of the hypotheses and findings of this Chapter. Most of the hypotheses are confirmed by the results. However, some predictions were clearly contradicted or only weakly supported by the findings. These are discussed below.

Table 3.22: Summary of the results

\begin{tabular}{|c|c|c|c|c|}
\hline Hypothesis & Analysils & Techniques & Prediction & Resuits \\
\hline I Age-Aailure & Postentry & PPMC, Chi-Square & - & ns \\
\hline 2 Age-shares & Pustwentry & PPMC & - & + \\
\hline 3. Ownership - ssize & Posteniry & Mann-Withney U & H. & + \\
\hline $4 A g 0-S i z$ & Post-entry & PPMC, Mann-Withney U & + & + \\
\hline \$ Age-growth & Post-entry & PPMC, OLS, Mann-Withney U & . & - \\
\hline 6 Age - productivity & Post-entry & PPMC, OLS, Mann Withney U & + & $\infty$ \\
\hline 7 size - growth & Post-entry & PPMC, OLS & - & - \\
\hline s size-produclinty & Post-entry & PPMC, OLS & * & + \\
\hline 9 size-Mullure & Pre-exit & Knuskal-Wallis, Mann-withney U & - & - \\
\hline 10 Oxnership - falure & Pre-exilt & Fisher's Exact test & - & ns \\
\hline II Gitowth - taillure & Prewexit & $\begin{array}{l}\text { Kruskal-Wallis, Mann-withney U, } \\
\text { Wilcoxon, PPMC }\end{array}$ & - & - \\
\hline 12 Productivily - failure & Prevexit & $\begin{array}{l}\text { Knuskal-Wallis, Mann withney U, } \\
\text { Wilcoxon, PPMC }\end{array}$ & - & - \\
\hline
\end{tabular}


The negative association between age and failure reported in earlier work is not reproduced in this study. While a correlation produced the negative sign, though not significant, the comparison between entrants" and incumbents" exit rates generated a positive outcome. Entrants showed lower exit rates compared to incumbent firms. The reason is probably that entry is operationalized as entry to the sample while agencies are founded severall years earlier. Entrants have just succeeded in obtaining a certain size threshold and have showed to be financially stable. They should be able to benefit from this position at least in the few years that follow.

A negative relation between age and market shares observed in earlier work was not reproduced in this study. To the contrary, most cohorts of entrants succeeded in increasing their market share over the post-entry period. This opposing finding is surely due to the fact that the failure rates of entrants are not as high as those observed in prior research and that surviving advertising agencies grow relatively fast. The requirements for entry to the sample have caused the bias towards the financially stable agencies.

In this study, an inverted U-shape was observed in the relation between age and size, which contradicts most research findings on the topic reporting a linear positive relationship. This result may be partly explained by the history of the advertising industry. The Dutch industry of advertising agencies is relatively young. The development of advertising agencies as we know them today took place after World War II. In the 1960s and 1970s, large American, multinational advertising firms entered the Dutch and other European markets. They simply followed their clients to the European market, and were glad to do so as their home country did not offer much growth opportunities anymore (Schreurs, 1992). These agencies are nowadays among the worlds largest multinational advertising companies. They are present all around the world, some of them in more than 60 countries. By internal growth, acquisitions and mergers, and, most important, with the back-up of the mother agency, these agencies have grown out to be the largest agencies to occupy the Dutch market. No independent Dutch advertising firm has yet reached the size of these agencies. The reason is that (internal) growth is difficult to obtain in the advertising industry. An agency onlly obtains large, international, accounts if it is large (and international) itself. Therefore, international clients are shared anong the large multinational firms, mostly decided at mother agency level. Since all worldwide agencies are already present in the Dutch market, having a place in the top twenty, no big changes in the top of the industry is to be expected in the near future. Moreover, this argument about the multinationals and their strength explains why the largest agencies are not the oldest agencies in the market. Howewer, when age and size are plotted without the multinationals, a somewhat different picture emerges. Indeed, the largest agencies are now omitted from the plot. Now, size appears to increase quickly with age and to decline slowly afterwards. The predicted positive relationship between age and size is still not reproduced in the results. In the Dutch 
advertising industry, a positive relationship between age and size clearly does not exist.

In this study, first a larger productivity level was observed for incumbents than for entrants, which seemed to support the predicted positive relationship between age and productivity However, further analyses showed that this relationship is actually negative. The criteria applied for entry to the sample have caused the confusing result. Those agencies fulfilling several financial criteria before 1984 were included in the sample from the beginning of the time period, e., were incumbent. Others enter after 1984, when they fulfill the necessary requirements. These criteria imply that young efficient firms are included in the sample starting from 1984. They belong to the incumbents, which enhances the productivity level of this group. Old, less efficient agencies enter the sample after 1984 and are included in the entrants group, which decreases the latter's average productivity level. This result, thus, confirms the application of the entry criteria. An interpretation for the negative relationship between age and productivity in terms of Jovanovic (1982) runs as follows. The younger firms in the sample are those that have fullilled the entry requirements relatively fast after founding. The young agencies have, thus, already learned their efficiency/productivity level. They have just succeeded in obtaining a certain size threshold and have showed to be financially stable and should be able to benefit from this position at least in the few years that follow. Their performance in terms of productivity and growth may therefore compare favorably to the older firms" performance.

While the findings provide strong evidence for a negative linkage between productivity and exit, the predicted negative relationship between firm growth (income and staff growth) and exit is only partly confirmed by the results. The findings provide no evidence for a clear pattern of declining growth rates in the years prior to failure. Furthermore, the comparisons of all exiters with all survivors and the matched-pair analyses produced significant differences in growth rates only in several years and some groups prior to exit. Several remarks with respect to the insignificance of the pre-exit performance results are noteworthy. First of all, exiting firms were shown to be relatively small. Due to the measure of growth (percentual), small firms grow faster than large firms. Large firms performing badly are not forced to exit the market immediately. They have the possibility to (slowly) decline and achieve a lower, more profitable size level (Dunne and Hughes, 1994). The existence of small firms is much more fragile. A low or negative growth rate will directly threaten their existence. It is, thus, not an unexpected result that small agencies are, on average, faster growing, but also more likely to exit. This result has been reported in former research as well For instance, Blau (1984) found that small New York architecture firms are more profitable, but large firms are more likely to survive. So, it may be the case that exit of advertising agencies is not always preceded by relatively slow or negative growth. This would be consistent with the findings of Audretsch (1995). Though his study concerned the manufacturing sector, it does prove that failure is not 
necessarily associated with negative growth.

Second, an important selection criterion for advertisers to choose an advertising agency is the latter's financial stability or health. Since the intention of an advertiser is a durable relationship with an agency, (s)he is not likely to select an agency that has a chance of faillure in the near future, which implies a great chance that the relationslip will be terminated prematurely so that money and time will be lost. Agencies are therefore very keen on reporting positive income growth figures. Staff size changes may therefore be a more reliable indication of the financial health of an advertising agency.

Third, the set of banknupt and dissoluted agencies consists of several firms that exited the sample several years before the bankruptcy or dissolution actually took place. Probably, in the years between exit from the sample and bankruptcy or dissolution these agencies either did not report their income and other characteristics or refrained from handing in their surveys to the sources altogether. The fact that we do not observe a more significant negative growth pattern for bankrupt and dissoluted agencies, may thus be caused by the definition of exit and, of course, the lack of data for crucial years. Furthermore, since advertising agencies are rather small firms with the agencies exiting the sample being especially small, the decline in the growth pattern prior to exit was supposed to be rather short. However, the present results now point to an extremely short period of decline of two years prior to exit.

Fourth, exit barriers are not very large in the advertising industry, especially not for the smaller agencies. They may have contracts with advertisers, but no important sunk costs. The staff and income growth figures lead us to believe that most small agencies exit relatively fast when their situation is unsatisfactory.

A final important comment is the fact that income growth is not equal to profits. Firm growth is generally used in the post-entry performance literature as a kind of performance measure. And while income growth is a frequently applied proxy in the advertising industry to assess performance, it is at best indicative of the profitability level. Firms declining simulta neously in income and staff size may remain as profitable as before. And those declining in staff size but increasing in income, may even be more profitable than before. A low growth pace does not mean that an agency is unprofitable. In this sense, productivity, as it is measured here, may be a better indicator of profitability. If that is the case, then the results do point out that the worst performing advertising agencies exit the market first. The model of Jovanovic (1982) implies that efficient firms grow and expand, while inefficient firms remain small "and may be forced to exit from the industry if they are operating at a suboptimal scale of output (Audretsch and Mahmood, 1994: 245). Apart from the mergers, the productivity level of exiting advertising agencies is below the average level of survivors during most years before exit. Thus, they are still not able to work as efficiently as survivors, and as Jovanowics' theory predicts, faced with these below-average efficiency levels, the agencies are forced out of the 
industry or contract their firm size (below the minimum acquired size to be included in the research sample).

The results consequently show different findings for firms exiting the samiple for different reasons, which underlines the importance of distinguishing between various exit modes. Especially the performance of agencies that disappear due to a merger or acquisition stands out. Relative to the other failing agencies and to survivors, these agencies were effectively the best candidates for take-over or merger. In effect, they had a positive and relatively high income growth in the years preceding merger or acquisition, a moderate negative staff growth directly preceding exit and a rather high staff growth pace in earlier years and, finally, a relatively high productivity level. They were, on average, doing rather well. A merger or acquisition made it possible for them to grow at once to a higher size level.

\subsection{Conclusions}

The aim of this chapter was to assess the post-entry and pre-exit performance of Dutch advertising agencies over the period 1984-1994. The results point out that, in accordance with prior research in manufacturing industries, most entrants are independent, relatively small, rather efficient and grow relatively fast in the years following entry. The period preceding exit appears to differ substantially between firms disappearing for different reasons. On the one hand, bankrupt and dissoluted agencies and 'insufficient data exiters' are relatively small, relatively inefficient and show rather slow growth rates in the years preceding failure. Agencies that exit because of a merger or acquisition, on the other hand, are larger than the average survivor, have about average growth rates prior to exit, and are exceptionally efficient in the pre-exit years, which makes them attractive targets for mergers or acquisitions.

The analyses carried out in this chapter indicate that the definition of entry, as applied in this chapter, i.e., entry to the data set, is not always a very fortunate one. It obscures some relationships. However, data restrictions (the unavailability of data in years precedling entry to the sample) made it impossible to use the traditional founding year as the year of entry. 


\section{CHAPTER 4}

\section{ORGANIZATIONAL CHANGE AND BUSINESS SUCCESS}

\subsection{Introduction}

Should an arganization display flexible behavior or should she be inent in order to survive? Organizational ecologists (Hannan and Freeman, 1977 \& 1984) stress the importance of inertia for survival, whereas organizational choice adherents (e.g., Johnson and Scholes, 1993) emphasize that organizations should be flexible in order to surviwe. Research on the consequences of organizational change, testing the inertia and adaptation theories, has focused primarily on survival probability. However, survival and financial success are not necessarily related aspects of performance. The two measures of performance have, in a number of studies, been shown to be determined by different processes (see, e.g., Blau, 1984; Carroll and Huo, 1986; Boone and Van Witteloostuijn, 1995). One study in the ecology tradition on organizational change and performance (Haveman, 1992) found some consistency in the results for both performance measures. However, this study pertains to diversification activities only. So, additional research involving the effect of organizational change on different performance measures is needed.

Furthermore, the effect of organizational change on firm performance may be mediated by organizational size. Hannan and Freeman (1984) state that "it is not clear whether small or large organizations have higher overall rates of successfully implementing change" (Hannan and Freeman, 1984: 163). Despite their comment that the question whether organizational change is more distuptive in small compared to large firms clearly deserves toro theoretical and empirical attention, the matter has not received much notice in the organizationa ${ }^{2}$ change literature (Baum, 1996). One exception is a study by Haveman (1993b), but she addressed the topic indirectly by examining the effect of size on the extent of change (market diversifcation). She found a positive relationship between size and diversification activities, and "concluded that large organizations are more capable of taking advantage of the opporturities to enter new and promising markets than are small organizations" (Haveman, 1993b: 20). Rescarch on the mediating effect of organizational size in the organizational change - performance relationship is clearly needed.

The present study adds to the existing literature by addressing both issues simultaneously. That is, the impact of organizational change is examined on both financial performance and the probability of survival and the analyses are carried out separately for small and large firms. In addition, while Haveman (1992) included only diversification activities, this study extends the 
range of change variables to mutations in ownership and board composition. The study is conducted in the Dutch advertising industry, in the period 1984 - 1994.

The chapter is organized as follows. The next section gives a short description of the organizational adaptation and organizational ecology perspectives. Prior research on organizational change is briefly discussed in Section 4.3. Section 4.4 goes into the specificity of organizational change in the advertising industry, and introduces the hypotheses. In Section 4.5 , the methods are described. Section 4.6 presents the results. The chapter ends with a discussion in Section 4.7 and concluding remarks in Section 4.8 .

\subsection{Theory on organizationall change and firm failure}

Since the late 1970s, research on organizational change and survival has been dominated by two streams of research: the traditional adaptation perspective and organizational (or population) ecology. The two theories are, generally, treated as contradictory views. On the one hand, classical schools of organizational analysis, all in the adaptation tradition, by and large argue that organizations are flexible and have the ability to change without facing unsurmountable obstacles. Top managers and dominant coalitions change their organizations in order to adapt to transformations in their environment Organizational changes are believed to produce a better fit between the organization and the environment (e.g., Lawrence and Lorsch, 1967; Johnson and Scholes, 1993), and are thus assumed to be beneficial for the performance of organizations and to decrease organizational mortality (Singh et al, 1986). According to Singh et al. (1986), examples of theories and theorists building on the adaptation theme are contingency theory (Daft, 1983), resource dependence theory (Pfeffer and Salancik, 1978), institutionalization theorists (DiMaggio and Powell, 1983), theorists of organizational strategy (Miles and Snow, 1978) and theories of organizational learning (Levinthal and March, 1984).

In the organizational ecology view, on the other hand, it is assumed that (i) strong inertial pressures impede organizations to change (Hannan and Freeman, 1989) and (ii) organizational change increases mortality chances (Hannan and Freeman, 1984). According to population ecologists organizations are highly inert: organizational changes occur, but they come about much more slowly than envirommental changes (Hannan and Freeman, 1984). Relative inertia is, however, believed to be fundamental for organizations to survive. In order to survive organizations should be characterized by three features of inert organizational structures (Hannan and Freeman, 1984). First, organizations have to be reliable: they need to be capable of repeatedly producing products of sustained quality. Second, organizations have to display high accountability: that is they should be able to account rationally for their actions. Third, and this is a requirement for reliability and accountability, organizationall structures must be thighly reproducible i.e., the organization's structures of roles, authority and communication of today have to be the same as they were yesterday. 
Organizational ecologists argue that a fundamental change increases mortality chances as this resembles the creation of a new organization: the reliability of performance and the stability of structure will again be similar to those of a newly created organization. After a fundamental change has taken place, the mortality chances of a firm will therefore be as high as those of a newly founded organization (Hannan and Freeman, 1984).

Furthermore, ecology theorists argue that the extent to which changes occur and the effect they have on organizational performance, depend on organizational characteristics. Resistance to change is believed to increase with firm age and size. With age, reproducibility and, therefore, structural inertia increase, due to the fact that older firms have more strongly formalized internal relationships, standardized routines, institutionalized leadership and power distributions as well as established networks of dependencies and commitments with other social actors (Baum, 1996). Large firms are more resistant to change than small organizations since they "emphasize predictability, formalized roles, and control systems and their behavior becomes predictable, rigid and inflexible (Baum, 1996: 27).

Whille fundamental change is suggested to be more disruptive in older than in younger organizations, the relationship between size, inertia and failure is more problematic (Hannan and Freeman, 1984). Older organizations are especially likely to fail subsequent to organizational change because their routines, internal roles and formal structures are strongly established, which is different in younger firms. As to the question whether fundamental change is more disruptive in small or large firms, however, Hannan and Freeman (1984) have no decisive answer. In their argument they distinguish between the process of change and the final result of transformation: "We argue that small organizations are not only more likely than large ones to attempt change, but are also more likely to die in the process. Without further information on the magnitudes of the rates, it is not clear whether small or large organizations have higher overall rates of successfully implementing change. Our analysis suggests that it is premature to conclude that ecological theory may be applied nore readily to small than large organizations" (Hannan and Freeman, 1984: 163).

Discussing fundamental changes in organizations, Hannan and Freeman (1984) refer to shifts in core aspects of organizations, which they distinguish from changes in peripheral organizational features. Changes in core features are supposed to be rare and costly, and so to enhance the probability of organizational death. The core features of an organization are its goals, forms of authority, core technology and marketing strategy. Changes in goals are least likely to occur as they are most subject to constraints, while as one descends the four aspects, changes in marketing strategy are believed to occur most frequently (Hannan and Freeman, 1984). Peripheral feature changes are said to be common without altering the fundamental nature of organizations. Therefore, such changes are unlikely to affect survival chances (Hannan and Freeman, 1984). Examples of peripheral aspects of organizations are numbers 
and size of subunits, number of levels in authority structures, span of control and pattems of communication (Hantan and Freetran, 1984).

\subsection{Prior research findings}

A limited number of studies has tested the inertia and adaptation views by examining the effect of organzational change on firm performance. This section presents a brief overview and an evaluation of the empirical results on the topic. The outcomes of studies examining organizational change and survival are described first, followed by the results concerning financial performance: Subsequently, findings on the mediating effect of organizational size in the organizational change - performance connection are reported. And finally, theory and research findings are discussed, and the purpose of the study is explained.

\subsection{Summary of research findings}

Table 4.1 summarizes (the most important) studies on organizational change and performance that were specifically designed to test organizational ecology and adaptation perspective assumptions. The theory of organization ecology focuses on the effect of organizational transformations on survival chances. The impact of core and peripheral changes on growth or profitability (in the short run) is, as yet, underemphasized in this theory. Table 4.1 indicates that, with the purpose to test inertia theory, recent empirical studies on organizational change and performance have, generally, operationalized performance in terms of the probability of survival or mortality (Singh et al, 1986; Kelly and Amburgey, 1991; Haveman, 1992; Amburgey, Kelly and Barnett, 1993). Only few studies in this research stream have investigated the impact of organizational change on financial performance measures (see, e.g., Haveman, 1992 for an exception).

Most studies distinguish core from peripheral changes. In the field of strategic management, however, the relationship between organizational change and organizational performance measured in terms of profitability has received much attention [see, e.g., Ramanujam and Varadarajan (1989) for a review of diversification studies]. The research in the field of strategic management, however, does not make the distinction between core and peripheral changes.

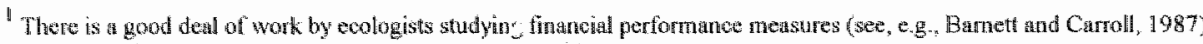
but ratrely with aespet to orgzmizational change and performanee
} 
Table 4.1: Summary of studies on arganizational change and penformance

\begin{tabular}{|c|c|c|c|c|}
\hline Authors & Sample & Independent wantable & $\begin{array}{l}\text { Relation with } \\
\text { probublitity of } \\
\text { failume }\end{array}$ & 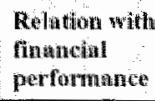 \\
\hline $\begin{array}{l}\text { Armbugey, Kelly } \\
\text { and Burpet (1993) }\end{array}$ & $\begin{array}{l}1011 \text { newspapers published } \\
\text { in Finland between } 1771 \text { - } \\
1963\end{array}$ & $\begin{array}{l}\text { Change in newspaper content } \\
\text { Change in frequency of } \\
\text { newspaper fubliwainen }\end{array}$ & + & \\
\hline Carroul (1984) & $\begin{array}{l}2137 \text { Us newspaper } \\
\text { orgamizations, } 1800-1975\end{array}$ & Founder suceession & + & \\
\hline $\begin{array}{l}\text { Delacrox and } \\
\text { Swaninathar } \\
(1991)\end{array}$ & $\begin{array}{l}919 \text { Callormingn wineries, } \\
1946.1984\end{array}$ & 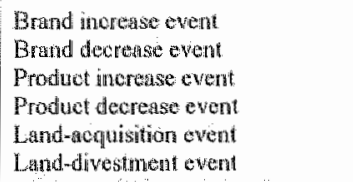 & $\begin{array}{l}0 \\
0 \\
- \\
0 \\
- \\
0\end{array}$ & \\
\hline $\begin{array}{l}\text { Halrubrick and } \\
\text { DAweni }(1988)\end{array}$ & $\begin{array}{l}57 \text { mnatched paigs surviving } \\
\text { and faing large Us } \\
\text { organzations }\end{array}$ & $\begin{array}{l}\text { Domain inituatives (acquisition or } \\
\text { starfing an new unis) }\end{array}$ & 0 & \\
\hline Havethan (1992) & $\begin{array}{l}313 \text { Californitan savings and } \\
\text { loan assowations } 1977 \\
1987\end{array}$ & $\begin{array}{l}\text { Divergification in eight related } \\
\text { trarkets }\end{array}$ & $\begin{array}{l}5 d v^{4}: 0 \\
3 d v^{\prime} s:\end{array}$ & $\begin{array}{l}6 \text { diven: } \\
1 \text { div: } \\
1 \text { div: } 0\end{array}$ \\
\hline Haxemen (1993) & $\begin{array}{l}243 \text { telephone companies } \\
\text { and } 1230 \text { individuals } \\
\text { Southeastern lowa, } 1900 \text {. } \\
1917\end{array}$ & $\begin{array}{l}\text { Prossidential succession } \\
\text { Matuagerial suceession }\end{array}$ & + & \\
\hline $\begin{array}{l}\text { Kelly and } \\
\text { Amburgey }(1991)\end{array}$ & $\begin{array}{l}\text { 136 US certificated wis } \\
\text { carriers, } 1962-1985\end{array}$ & 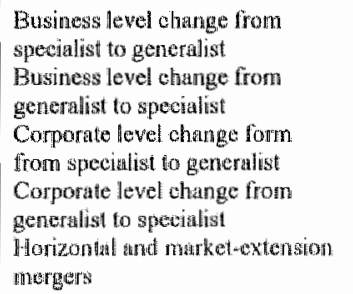 & $\begin{array}{l}0 \\
0 \\
0 \\
0 \\
0\end{array}$ & \\
\hline $\begin{array}{l}\text { Miller and Chien } \\
\text { (1994) }\end{array}$ & $\begin{array}{l}32 \text { US domestic airlines, } \\
\text { with rewentes oner } \$ 100 \\
\text { mittion, } 1979-1986\end{array}$ & 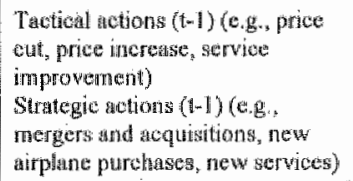 & & . \\
\hline $\begin{array}{l}\text { Singh, House and } \\
\text { Tucker }(1986)\end{array}$ & $\begin{array}{l}389 \text { voluntary social service } \\
\text { organizations, } 1970 \times 1982 \\
\text { in Toronto, Catnada. }\end{array}$ & 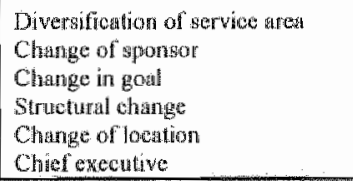 & $\begin{array}{l}\pi \\
+ \\
0 \\
0 \\
- \\
-\end{array}$ & \\
\hline
\end{tabular}




\subsubsection{Organizational change and survival}

The studies intended to test the inertia and adaptation perspectives have generated contradicting findings (see Table 4.1). Some support the inertia model, finding a positive relationship between organizational change and failure chances. Others find no support for the inertia nor the adaptation theories, reporting the absence of a relationship. And finally, a number of studies obtain different outcomes depending on the change variable under study, suggesting that the findings are contingent upon situational characteristics. Not one study reports exclusive support for the adaptation view.

Support for the inertia perspective comes from Amburgey, Kelly and Barnett (1993), who studied the effect of organizational core changes on failure rates among 1011 newspapers published in Finland in the period 1771-1963. The occurrence of two types of core changes a change in content - generalized versus specialized news - and a change in the frequency of publication) "reset the liability-of-newness clock and increased the risk of failure above what it would have been otherwise" (Amburgey, Kelly and Barnett, 1993: 68). Haveman (1993a) and Carroll (1984) also report a positive impact of core change on the probability of failure. Haveman (1993a) observed increased failure rates due to presidential and managerial succession in the telephone industry in Southeastern lowa in the period 1900-1917. Carroll (1984) reports that the probability of failure increased subsequent to founder succession among 2137 US newspaper organizations in the period 1800-1975. A positive connection between two of four organizational core changes and the probability of failure is, furthermore, reported by Singh et al. (1986) among Canadian voluntary social service organizations. Changes in two organizational core features (change in service area and sponsor change) significantly increased the mortality rate of these service firms.

Absence of a connection between core change and organizational failure is reported by Kelly and Amburgey (1991). A change from a generalist to specialist profile or vice versa in the U.S. air carrier industry yielded mo relationship with organizational failure. Most of the outcomes reported by Haveman (1992) also point to the absence of a connection. She examined the effects of organizational change (diversification), during sudden environmental transformation, on financial performance and survival of Californian savings and loan associations. Five out of eight changes were not related to organizational death. Delacroix and Swaminathan (1991) report the absence of a connection between four (out of six) core changes and the probability of failure. In the Californian wine industry, brand portfolio increase, brand portfolio decrease, product pontfolio decrease and land-divestment appeared to be unrelated to failure chances. Hambrick and D'Aveni (1988), who studied 57 matched pairs of failing and surviving large US firms, found no differences in the domain initiatives undertaken by the successful and unsuccessful organizations. Finally, Singh et al. (1986) report that two of the four core changes under study (goal change and structural change) failed to affect the death 
rate of volumary social service firms.

Partial confirmation of the adaptation perspective is provided by Haveman (1992), who observed, among Californian savings and loan associations, that three out of eight diversification changes diminished failure rates. Delacroix and Swaminathan (1991) found two (out of six) core changes, product increase and land-acquisition, to diminish the probability of failure. Singh et al (1986) report a negative effect of changes in peripheral features of organizations (change of chief executive and location change) on organizational survival rates; among Canadian voluntary social service organizations.

\subsubsection{Organizational change and financial performance}

Only Haveman (1992) and Miller and Chen (1994) examined the influence of organizational core changes on financial performance in the context of specifically testing the adaptation and structurall inertia perspectives. Support for the inertia theory is provided by Miller and Chen (1994) in the US airline industry. Core changes (strategic actions, i.e, actions involving significant investments in fixed assets, people or structure) decreased financial performance of airline carriers. Peripheral changes (tactical actions, i.e, actions not involving significant longterm commitments of fixed assets) were not significantly related to financial performance. To the contrary, the results of Haveman (1992) tend, in balance, to support the adaptation perspective. Six of the eight changes (diversification activities) improved financial performance, whereas one change was harmful and one was unrelated to financial outcomes.

The results obtained by studies in the strategic management tradition on the relationship between organizational change and financial performance are as unequivocal as those produced by the research on organizational change and survival and financial performance. A positive relationship between leader succession and profitability is obtained by Lieberson and $\mathrm{O}^{\prime} \mathrm{Connor}$ (1972), Weiner and Mahoney (1981), Smith, Carson and Alexander (1984) and Thomas (1988). A negative association between announcements of CEO changes and the stock value of firms is reported by Beatty and Zajac (1987). And absence of a connection between replacement of the top management team and firm success is reported by Schreuder (1993). Furthermore, diversification activities have been found to be negatively associated with profitability by Rumelt (1974 \& 1982). And finally, Schreuder (1991), who studied matched pairs of success-full and unsuccessful medium-sized Dutch firms, observed that the successful firms engaged more in within industry diversification, whereas the unsuccessful organizations engaged more in outside industry activities.

\subsubsection{Organizational change and the mediating effect of firm size}

Hannan and Freeman (1984) suggest that the effect of organizational change on performance depends upon firm age and size. The mediating impact of age has been demonstrated by Singh 
et al. (1986). Changes made in the beginning of the life cycle appeared to have a more substantial impact on the hazard of death than transformations that occurred later in the life cycle. The mediating effect of firm size in the organizational change - performance connection has, however, recejved far less attention. In one study by Haveman (1993b) the relationship between organizational size and change is certral. However, she focused on the linkage between inertia and firm size, and did not test whether the effect of the changes differ with firm size. Nevertheless, Haveman (1993b) concludes that as the larger organizations engage in more diversification activities, these changes are more beneficial for large thian for small firms.

\subsubsection{Evaluation of theory and research findings, and purpose of the study}

The inconsistent findings on the effect of organizational change on survival chances and financial performance may be explained by the fact that the relationship is industry specific (the studies are carried out in a wide range of industries), time specific (some studies are carried out in the beginning of the century, while others are conducted in the $1980^{\prime} \mathrm{s}$ ) and, finally, change type specific (changes in core features are more disruptive than peripheral feature changes). Moreover, the consequences of organizational transformations also depend upon firm age and size.

Several studies report exclusive support for the inertia theory, while others notice the absence of a significant linkage between organizational change and performance. Some studies produced different connections for different change variables. Not one study reports confirmative evidence for the adaptation view only. In order to integrate the two contradictory views, i.e, the inertia and adaptation perspectives, Singh et al. (1986) propose to change slightly the distinction between core and peripheral changes made by Hannan and Freeman (1984). Both Singh et al. (1986) and Hannan and Freeman (1984) argue that core changes, on the one hand, wre disuptive and may best be described by an ecological view. Peripheral changes, on the other hand, are suggested to have no effect on performance by Hanman and Freeman (1984), whilte Singh et al. (1986) suppose that they increase survival chances and may thus best be described by an adaptation view. Unfortunately, interpretation of the results with Singh et al."s separation in mind does not account for the mixed organizational change effects summarized in Table 4.1. The studies reviewed above depart from an ecological viewpoint, predicting that organizational core transformations have a detrimental effect on survival. Selection and defintion of the core (and peripheral) change variables under study has, generally, been based on prior research and the definition provided by Hannan and Freeman (1984). However, the inconsistency in the research outcomes suggests that a better approach may be to take the industry under study as a starting point. That is, based on industry specifics, one determines whether an organizational feature refers to the core of the firm or to its periphery, and defines the change in aspects concordingly. This can imply that a certain change 
has (or is predicted to have) a disruptive effect in one industry (a core change), but a beneficial impact on organizational functioning in another industry (a peripheral change). Finally, a contingency theory could be developed that identifies the organizational or industrial aspects that explain why some changes are disnuptive in one firm or industry but beneficial in another. Organizational aspects that may be of importance in this respect, are organizational size and age. Singh et al. (1986) argue that the type of organization may play a role: i.e., organizational change may have a stronger impact on the performance of institutional organizations than technical organizations. A key industry characteristic may be the degree of dynamism.

The mediating effect of firm size in the relationship between organizational change and performance is, as yet, understudied. Concluding that organizational change is beneficial from the observation that it occurs relatively often (see Haveman, 1993b), seems to be a meager basis. Nevertheless, at least some changes may be suggested to have a dissimilar impact on the performance of small firms and large organizations. For instance, Haveman (1993a) pointed to the fact that managerial succession is probably especially disruptive in small organizations as "the positions of small-firm managers are not separate from the personalities and skills of the individuals who fill them" (Haveman, 1993a: 866).

The impact of organizational change on different performance measures is currently understudied too. Previous research has indicated that survival chances and financial performance are not intertwinable measures of performance (Winter, 1964; Boone and Van Witteloostuijn, 1995). However, the study in Table 4.1 that has included both performance measures (Haveman, 1992) generates consistent outcomes for survival and financial performance. In the study by Haveman (1992) the outcomes for the two performance measures are not always equally significant, but the direction of the relationships consistently concordes. However, the study examines the impact of diversification activities only. It is important to extend the analyses to other organizational change variables.

The present study takes into account the various points discussed above. We depart from the viewpoint that whether an organizational feature refers to the core or the periphery of an organization is contingent upon the industry. The formulation of the hypotheses will, therefore, be preceded by the identification of core and peripheral organizational features of Dutch advertising agencies. Moreover, core and peripheral features are considered as the two extremes of a continuum. This implies that for some organizational aspects, which are located. around the middle of the continuum, it is not as clear as for others whather they should be considered a core or a peripheral feature. Furthermore, the present analysis adopts the definition of core and peripheral changes by singh et al. (1986). That is, those aspects that are suggested to refer to the core of an organization are predicted to have a negative impact on performance while features relating to the periphery are expected to have a positive effect on frm performance. Finally, in order to fill omissions in the empirical literature, the present study 
concentrates on the importance of firm size in mediating the organizational change performance reliationship, and examines the impact of changes on both financial performance as well as the probability of failure.

\subsection{The advertising industry and the hypotheses}

The Dutch industry of advertising agencies seems to be an appropriate setting to study the effect of organizational change on performance for several reasons. First, Dutch advertising agencies are rather small firms (the average staff size is 19 employees; see Chapter 2), which should imply that they are able to change relatively fast. And second, during the time period under study; the industry has gone through transformations that have affected strategic and internal organizational behavior of advertising agencies. Here, the enlargement of the scope of services demanded (Nieman, 1989) and the increased pressure upon the agencies" financial positions (Mutsaerts, 1992) are particularly important. During the eighties and nineties, the importance and complexity of specialized services, such as direct marketing, sales promotion and media buying have increased, affecting the positioning and structure of advertising firms. This resulted in the provision of more services in-house, rendering specialized units independent, and the foundation of specialized agencies ${ }^{2}$ (Schreurs, 1989). Furthermore, the financial position of advertising agencies came under pressure mainly by the decrease in the growth rate of advertising expenditures, and by the increasing awareness of advertisers vis à vis their advertising costs, in which they required more insight and upon which they wanted more influence (Adformatie, 1994).

The present study involves six organizational changes: change in diversification of client portfolio and services, location, ownership structure, top management team composition, and agency names. The first three transformations, on the one hand, are believed to have a direct impact on performance. The effects of the three latter modifications on performance on the other hand, are supposed to be both direct and indirect. That is, they are believed to affect performance directly by influencing the attraction of clients. And they are assumed to have an indirect impact on performance as they are suggested to refer to strategic alternations (of the aspects under study and strategic features that could not be measured in this study).

Four of the six changes studied in this chapter are believed to represent transformations in advertising agency's core aspects: change in diversification of categories of clients and services, ownership structure and top management team composition. Two changes are suggested to be modifications in peripheral features: location and name change. This is explained below. Hypotheses are formulated in consistency with the definition of an aspect as a core or peripheral agency feature.

\footnotetext{
${ }^{2}$ Personal comment to the atuthor by H. Nieman, director of the advertising industry elssocitstion the Vea
} 
Two important aspects of the positioning of an advertising agency are the degree of specialization in terms of clients and services. Clients are classified according to the kind of products they produce or services they deliver (e.g., fast-moving consumer goods or businessto-business products). The creation of an advertisement demands a different approach, and therefore specific know-how and experience, according to the category of clients whom it aims at. Advertising agencies may be specialized in one or more client categories. Adwertising agencies may also differ in the range of media services they provide. Media services refer to the kind of media an agency makes advertisements for, e.g., radio, television and printed advertising. Again, each category requires specific knowledge and experience.

The client and media service portfolio are, thus, believed to be core aspects of advertising firms. Changes in these two core features are assumed to have a negative impact on advertising agencies"subsequent performance.

HI Change in client diversification has a negative effect on advertising agency performance.

H2 Change in service diversification has a negative impact on advertising agency performance.

The ownership structure and top management team composition are believed to be important core features for Dutch advertising agencies for two reasons. First, strategic decisions of advertising firms are taken by their top managers and owners. The positioning and orientation of an agency is determined by the individuals in charge. "If they are replaced, the positioning and orientation of an agency changes immediately ${ }^{333}$. And second, ownership structure and the composition of the top management team affect the attraction and retention of clients. The two organizational aspects are related since top managers of adwertising agencies are often partmers too. The role of ownership structure and top management team composition in the attraction and retention of clients is explained below

Dutch advertising agencies are either entirely owned by their managers, completely owned by a larger agency, often a multinational advertising firm headquartered in New York, London or Paris, or partly in the hands of both categories of owners. The image of an advertising agency depends to a certain extent on whether or not it is owned by a large advertising firm, influencing the attraction of potential clients. Generally, large international advertisers will place their account at a multinationally owned agency only. In addition, an agency that is (partly) owned by a larger advertising firm, may obtain accounts that are acquired at the

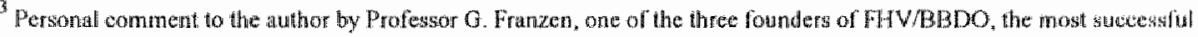
angency on the Netherland:s.
} 
headquarter level.

The attraction and reterition of clients are also influenced by the individual members of the board. The importance of people is paramount in service firms. The centrality of the Individual in the advertising industry is reflected in the importance of (i) perceived service quality and (ii) personal relationships. Services are largely "people-work", and one can, thus, expect differences in service performance between individuals as well as of an individual over time (Enderwick, 1992). Most services are, therefore, characterized by variation in quality, which makes it difficult to control current quality and to assure future quality. The accumulation of past performance (work) is an indication of the competencies of an individual (or agency). It determines the service quality perceived by advertisers. This explains why in the advertising industry "name" and "reputation" of individuals are often key characteristics for attracting clients (Commission of the EC, 1994). Furthermore, personal relationships are important since advertising agencies have long-lasting rellationships with clients. Top managers have direct and frequent contact with clients. The duration of the agency-client relationship is largely affected by its quality. For the relationship to work, the individuals concerned need to get along well. Personal characteristics of top managers may, therefore, play a role in the choice of an advertising agency and may also influence the decision to switch to another agency ${ }^{4}$. In sum, mutations in the top management team may, thus, influence the attraction of new clients and affect the continuation of existing agency - client relationships.

In addition, the effect of managerial succession on organizational performance may be strong in the advertising industry, since agencies are relatively small organizations. It is suggested that the impact of managerial succession on performance is stronger in smaller compared to larger organizations (Haveman, 1993a). Since small firms are managed by lew individuals and are controlled by direct supervision, a larger part of the performance variation of small organizations is explained by the personal characteristics and preferences of their managers (Preisendörfer and Voss, 1990; Boone and Van Witteloostuijn, 1995). Furthermore, managerial succession is less disruptive in large organizations than in small firms, because in large firms succession has become a bureaucratic event (Grusky, 1961). Based on the arguments above, changes in ownership siructure and top management team composition are suggested to be core aspects and have a negative impact on advertising agency performance.

H3 Change in ownership structure has a negative impact on advertising agency performance.

\footnotetext{
${ }^{4}$ Chapter 5 inwolves the role of personal characterastics in advertising agency performance.
} 
Change in top management team composition has a negative impact on advertising agency performance.

The location of an advertising agency is a strategic decision for two reasons. First, the agency client relationship is characterized by frequent contact and, generally, advertisers prefer to cooperate with an agency that is located nearby. Second, the location of the agency is important since it saves costs to be seated close to suppliers. This implies that changes in location from one region to another will have consequences for these two aspects. However, removal from one city to another will not seriously affect the (dis)advantages of the two strategic facets of location so that this type of modification may be considered peripheral. As a matter of fact, agencies may decide to move closer to their clients and/or suppliers, which should enhance performance. Since the current study measures location change as removal to another city, it is assumed to have a positive impact on advertising agency performance.

H5 Change in location has a positive effect on advertising agency performance.

Finally, the mames of advertising agencies are often made up of the imitials (or full names) of the owners, or indicate the specialization of the firm. As was explained above, both the owners and specialization of an agency are core features. However, since name changes do not always have a strategic meaning and are not always carried through at the exact timing of the more important transformation of which they are an external expression, they are suggested to be peripheral feature changes. Consequently, name transformations are assumed to have a positive influence on advertising agency performance.

H6 Change in name has a positive effect on advertising agency performance.

Firm size is expected to mediate the effect of organizational change on advertising agency performance. Large firms may have more slack resources and competencies than small firms to buffer against the (unforeseen) negative consequences of core changes, and they may benefit more quickly from the changes in peripheral firm aspects. Organizational change may, there fore, be expected to have a stronger effect on the subsequent performance of smaller agencies than of larger advertising firms.

H7 The effects of core and peripheral changes on performance are more pronounced among smallit than among large advertising agencies. 


\subsection{Merhods}

\subsubsection{The scmple}

The restarch sample consists of 189 Dutch advertising agencies over the period $1985-1994$. The original sample included 1984 as well, but since the examination of orgatizational changes implies a loss of the lirst year of observation of a firm, this year is excluded from the analyses. A number of agencies is not in the sample during the whole time frame because of founding atter 1984, failure before 1994 and missing observations. The total number of firms in the data set, therefore, exceeds the average number of agencies annually in the sample, being 97 , with a maximum of 1.14 and a minimum of 61 . The sample consists of 965 observations. Agencies were included in the sample only in years for which information on each of the independent and dependent variables was availlable.

The data on advertising agencies' structure, strategies and board composition were taken from the "Adformatie Bureaubijlagen", "Blauwe Bugamor", "Blauwe Burogidsen" and "Blauwe Bureau Tribune". The 'Adformatie Bureaubijlagen' and the "Blauwe Bugamor", "Blauwe Burogidsen" and "Blauwe Bureau Tribune' are annual listings of the most important Dutch advertising agencies, including several of their characteristics such as name, geographic Jocation, clients served, services delivered, number of employees, ownership, board members and income. For each advertising agency these key variables were recorded annually. Information on the founding year of agencies was obtained from local Chambers of Commerce. Data on failure, mergers and name changes were collected from industry magazines ("Adformatie") and annual reports of the industry associations the Vea and the Rota

\subsubsection{Variables and measurement}

The dependent variable is the performance of advertising agencies. Performance is operationalized in terms of firm income, firm growth and firm failure. Firm income is measured by the natural logarithm of the gross income of advertising agencies. Gross agency income is the difference between the sum of money invoiced to clients and the amounts paid to suppliers (on behalf of the clients). Gross income is measured in millions of Dutch guilders (constant 1994 prices). Firm growth is operationalized as gross income growth, which is a frequently used proxy in the advertising industry for agency performance. It is measured by $\Delta \ln ($ income). Failure means exit from the sample before 1994, referring to either banknuptcy, dissolution or insufficient data ${ }^{5}$. Firms exiting the data set due to a merger or acquisition are not treated as failures. These companies continue to exist, although in a new form. Furthermore, Chapters 2 and 3 have demonstrated that this category of exiters differs significantly from the other categories in terms of size and pre-exit performance: they are larger and perform relatively well

\footnotetext{
${ }^{5}$ Ser Chinpter 2 for precise explanations of these exil eategories.
} 
in the years preceding the merger or acquisition.

The independent variables in the study are the four core and peripheral feature changes as well as several control variables. Control variables are inchuded in the analyses as they may account for the connection between organizational and company performance. The control variables are the absolute degree of service diversification and client diversity, firm size, board size, firm age, ownership status and location in the Randstad. The measurement of the independent variables, control and change variables, is described below.

The diversification in client portfolio is measured by the spread in income obtained by working for one or more categories of clients. Clients are classified according to the kind of products they produce (or services they deliver). Industry yearbooks ("Adformatie Bureaubijlagen") distinguish twelve categories of clients (or products): consumer durables, utility goods, service industries, financial services, retailing, business-to-business, pharmaceuticals, not-for-profit organizations, public services (governmental organizations), personmel recruitment, institutional, and remaining clients. Diversity of client portfolio is operationalized with the numbers-equivalent index, an alternative measure of the degree of diversification (Scherer and Ross, 1990). The numbers-equivalent index takes into account the percentage of income generated in the twelve client categories, as well as the number of client classes for which an agency works. The numbers- equivalent (NE) index is calculated through

$$
N E \text {-index }=1 / 2 \mathrm{~F}_{\mathrm{ij} \text { * }}^{2}
$$

where $F_{i j}$ is the percentage of firm i's income generated with client category j. When a firm works for one client category only, the measure reaches its minimum value of 1 . If the company generates an equal share of its incone with the various client classes, the index is equal to the number of client categories.

Service diversification is, as indicated in Section 4.4 , measured in terms of "media services". Media service diversity is, similar to client diversity, proxied with the spread in income gener" ated by providing advertisements for four major categories of media: printed advertising, radio and television commercials, promotional activities and "other media". This is a usual division of services applied in industry "yearbooks" ("Adformatie Bureaubijlagen"). Media service diversification is also calculated with the numbers-equivalent index?

Changes in client and media service diversity may consist of increases and decreases.

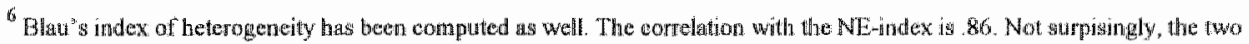
measures produce similar outcones.

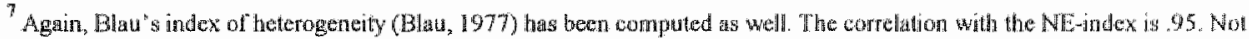
surpisifngly, again, the two measures generate almost idientical outcomes.
} 
Following Delacroix and Swaminathan (1991), the impact of the two types of changes on agency performance are estimated separately. Separate variables for increases and decreases are, therefore, constructed for each diversification measure. The positive change measure includes all the augmentations in the specific diversification measure with decreases set to zero. The negative change variable does the opposite, that is, decreases remain the same while increases are set to zero.

It must be noted here that in the case of a merger, all change variables (thus also income growth) are computed by comparing the value of the new merged firm with the average of the values of the two former independent agencies. For instance, in order to obtain the change in client diversity, the NE-indexes of the two independent firms in year $t-1$ are summed and divided by two. This outcome is, then, subtracted from the NE-index of the merged agency in year $\mathrm{t}$.

Ownership change refers to changes in the ownership structure of an agency. As mentioned in Section 4.4, Dutch advertising agencies are either entirely owned by their managers, completely owned by a larger agency, often a multinational advertising firm, or partly in the hands of both categories of owners. Changes in ownership may refer to changes between the categories of owners, as in the case of a management buy-out, and to changes withim the categories of owners, as when an additional manager becomes partner of the agency. Ownership change is reported with a dummy variable, 1 representing the occurrence of a change in ownership and 0 indicating the absence of such a change.

Changes in top management team composition refer to the addition and reduction of board members as well as to the replacement of top managers. A mutation in the top management teams is assessed with a dummy variable, a 1 referring to a change compared to the previous year, and a 0 denoting no change. Change of location is measured by the removal of the agency to another city. The change is reported with a dummy variable, 1 denoting a change and $O$ indicating the absence of locational change. The change in location is, thus, more specific than the control variable of location which indicates whether an agency is located in or outside the Randstad. A change in name refers to a mutation of the entire name or a key part of the name. The change is measured with a dummy variable again, 1 representing a change and 0 no change.

Firm size is an important control variable since it has been demonstrated to be related to survival chances as well as to growth rates (see, e.g., Dunne and Hughes, 1994; Doms et all, 1995). Among the present sample of advertising agencies size is, as expected, positively related to productivity and survival chances, and negatively to agency growth (see Chapter 3 ). While the analyses are carried out separately among a subsample of small and large agencies, firm size is included in both analyses as a control variable since within the subsets agencies still differ substantially in size. Agency size is measured in terms of the natural logarithm of the 
number of employees. Enpirical studies that have investigated the effect of team size on firm performance provide mixed results. Whille Eisenhardt and Schoonhoven (1990), for instance, report a positive relationship between firm growth and top management team size (absolute number of founders), Smith et al. (1994) observe an indirect negative effect of firm size on performance through the negative influence of team size on informal communication and social integration. Team size is measured by the natural logarithm of the number of executives in the top management team. Fim age has been found to be positively related to productivity and survival chances, and negatively to firm growth (see, eg., Dunne, Roberts and Samuelson, 1989a \& 1989b). Among the present sample of advertising agencies, and consistent with previous research, firm age revealed to be positively related to productivity and negatively to firm growth, but, contrary to the expectation, unrelated to survival chances (Chapter 3 ). Firm age follows from extracting the founding year from the observation year. Advertising agencies that are (partly) owned by multinational advertising agencies have the advantage of being assured of several international clients that are obtained at the headquarter level. Location of Dutch advertising agencies either in or outside the so-called Randstad may be an important predictor of agency performance. The Randstad is economically the most active part of the Netherlands. Most large advertisers and suppliers are located in this region which, therefore, provides the best opportunities for advancement. The region in which an agency is located, is denoted with a dummy variable, 1 indicating the Randstad and 0 referring to all other regions in the Netherlands. The Randstad is the city triangle Amsterdam, Rotterdam, Utrecht, which is proxied by the three provinces North Holland, South Holland and Utrecht. Finally, ownership status is measured with a dummy, 1 representing (partial) ownership by a large, multinational agency and 0 otherwise.

\subsubsection{Analyses}

The impact of organizational change on financial performance is investigated using regression models on pooled cross-sectional and time-series data. Fixed-effects models are estimated including a dummy variable for each firm and year. Fixed-effects models estimate only withinfirm wariation over time and eliminate across-firm variation (Judge et al., 1982), so consituting. a very conservative test of the hypotheses. The analyses are carried out on the set of firms whose information is available for at least two years.

In order to test the hypotheses with income and income growth as the dependent variables, Cobb-Douglas type functions, using fixed-effects estimators, are used to which measures of change in organizational core and peripheral aspects have been added, i.e., the increases and decreases in client and media services diversity, ownership changes, top management team mutations, and location and name changes. The Cobb Douglas function is used to measure the productivity of employees. The variables that directly concern labor are, therefore, measured in 
natural logarithms (staff size and board size)

To examine how organizational change affects the firm's probability of failure, logistic regressions are carried out: Since the number of firms that exit the sample is very small, the regressions are estimated on the average values of the firms over the time period they are included in the sample (cross-sectional analyses using agency means). The analyses include a control variable for the number of years a firm is observed in the sample. The reason is that the higher the number of years a firm is included in the data set, ceteris paribus, the larger the possibility that organizational changes have taken place.

\subsection{Results}

\subsubsection{Sample descriptives}

The descriptives of the sample of Dutch advertising agencies are presented in Table 4.2. The table provides the descriptives of the entire sample, and separately of small and large agencies. Small agencies are firms employing fewer than 10 employees, which is a standard cutting point applied by the CBS in this industry (CBS, $1991 \mathrm{et}$ seq.). The total number of firms in the sample (189) is lower than the sum of the number of small and large companies separately (75 and 137 , respectively). This is due to the fact that during the ten-year time period many agencies switch from being small to large, and vice versa. The entire sample of the study consists of 189 separate agencies and a total of 965 observations. The subsample of small agencies consists of 75 different advertising firms and 341 observations, and the subset of large agencies contains 137 agencies and 624 observations. The means and standard deviations are calculated using the pooled data set, i.e., the observations, except for exit, for which firm level information is used. On average, advertising agencies obtain an annual gross income of 4.16 million Dutch 1994 Guilders, employing about 20 people. Small agencies have an average workforce of almost 7 employees and generate an annual income of, on average, 1.25 million Guilders. Large agencies employ, on average, 26 people and achieve an average annual income of 5.75 million Dutch Guilders. The average growth rate (percentual growth in income) is about 6 percent for the whole sample. Not surprisingly, small agencies achieve somewhat higher growth rates compared to their large counterparts ( 7.28 versus 5.45 percent, respectively). Fifteen percent of all agencies exits the sample before 1994. Small agencies fail more frequently than large companies. While 23 percent of the small firms exits the data set during

\footnotetext{
"OLS models hive been oxried out ws well but likelihood ratio tests have indicated that fixed-effeets nindels explain significantly more varnance

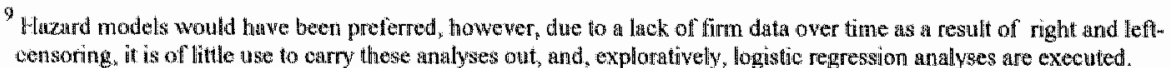


the time period under study ( 17 out of a total of 75 small agencies), only 12 percent of the large agencies experiences a similar fate (i.e., 16 out of 137 firms).

Table 4.2: Means and standard deviations of Duch advertising agencies

\begin{tabular}{|c|c|c|c|}
\hline Variables & All aggencies & Small agenties & Large agencies \\
\hline $\begin{array}{l}\text { Cross income } \\
\text { (in mtallions of } 1994 \text { DFL) }\end{array}$ & $\begin{array}{l}4.16 \\
(538)\end{array}$ & $\begin{array}{l}1.23 \\
(.58)\end{array}$ & $\begin{array}{l}5.75 \\
(6.12)\end{array}$ \\
\hline Sitaff size & $\begin{array}{c}19.55 \\
(20.31)\end{array}$ & $\begin{array}{l}6.85 \\
(1.56)\end{array}$ & $\begin{array}{l}26.49 \\
(22.37)\end{array}$ \\
\hline Boardl size & $\begin{array}{r}2.68 \\
(1.599\end{array}$ & $\begin{array}{l}1.78 \\
(82)\end{array}$ & $\begin{array}{l}3.17 \\
(1.69)\end{array}$ \\
\hline Grothidn (income) & $\begin{array}{c}6.10 \\
(20.31)\end{array}$ & $\begin{array}{l}7.28 \\
(23,57)\end{array}$ & $\begin{array}{c}5.45 \\
(18.25)\end{array}$ \\
\hline Firnu falkure ${ }^{2}$ & .15 & .23 & .12 \\
\hline Firm age & $\begin{array}{l}20.12 \\
(19.81)\end{array}$ & $\begin{array}{c}13.70 \\
(10.14)\end{array}$ & $\begin{array}{l}23.62 \\
(22.73)\end{array}$ \\
\hline $\begin{array}{l}\text { Ownuewship large } \\
\text { sulvertising firm }\end{array}$ & .20 & .05 & 20 \\
\hline Locstion in the Rundstad & .73 & .68 & .76 \\
\hline Clinent portfolfo diwersity & $\begin{array}{c}4.22 \\
(1.51)\end{array}$ & $\begin{array}{c}4.08 \\
(1.49)\end{array}$ & $\begin{array}{l}4,30 \\
(1.52)\end{array}$ \\
\hline Media serwike diversity & $\begin{array}{l}2.19 \\
(.54)\end{array}$ & $\begin{array}{l}2.12 \\
(.51)\end{array}$ & $\begin{array}{l}2.23 \\
(56)\end{array}$ \\
\hline Inerease elient diversity & $\begin{array}{c}.25 \\
(.61)\end{array}$ & $\frac{.22}{(97)}$ & $\begin{array}{c}.27 \\
(.63)\end{array}$ \\
\hline Decrease dient diversity & $\begin{array}{l}-.16 \\
(43)\end{array}$ & $\begin{array}{c}-.12 \\
(31)\end{array}$ & $\begin{array}{r}-.19 \\
(.49)\end{array}$ \\
\hline $\begin{array}{l}\text { Uncrease media senvice } \\
\text { diversity }\end{array}$ & $\begin{array}{l}10 \\
(22)\end{array}$ & $\frac{.08}{211}$ & $\begin{array}{l}10 \\
(22)\end{array}$ \\
\hline $\begin{array}{l}\text { Decreaste medin serwice } \\
\text { wiversily }\end{array}$ & $\begin{array}{l}.05 \\
(.17)\end{array}$ & $(17)$ & 8.06 \\
\hline Change awnership & 17 & .12 & .21 \\
\hline Change TMT composidion & .38 & .21 & 梏 \\
\hline Claange nasume: & .04 & .02 & .0 .5 \\
\hline $\begin{array}{l}\text { Change location } \\
\text { (renuowil to ofher city) }\end{array}$ & .01 & .01 & .01 \\
\hline $\mathbf{N}$ & 965 & 34 & 624 \\
\hline N fritrus & 189 & 75 & 137 \\
\hline
\end{tabular}

Means are given with standard devintions between parenthesect.

$7 \mathrm{~N}=1$ \&9 for all firns, $\mathrm{N}=75$ for small and 137 for large apencics.

Large advertising agencies are substantially older than small agencies. The average firm age in the entire sample is 20 years, with small companies being, on average, almost 14 years and 
large firms 24 years old: Furthermore, relatively more large than small companies are (partly) owned by a large advertising firm. The proportion is 20 percent for the entire sample of agencies, but 29 percent for large and 5 percent for small agencies, respectively. A similar pattern is observed with respect to location. While 73 percent of the whole sample of firms is located in the Randstad, 68 percent of the small and 76 percent of the large agencies are located in that region: Since most large advertisers and suppliers are located in the Randstad, large agencies are most often located there too. Small agencies do more business with local advertisers seated in all regions of the Netherlands

The advertising agencies in the sample are rather diversified, both in terms of clients and serwices. The average NE-index of clients is 4.22 , and of media services 2.19 . As could be expected, large firms have a somewhat more diverse client and media portfolio than their smailer counterparts. Furthermore, the agencies, both small and large, carry through only small changes in client and media service diversification. On average, firms enlarge their client and media service diversity during the 1984 - 1994 period.

In addition to the observation level descriptives, the occurrence of changes in ownership, top management team mutations, and name and location changes has been assessed at the firm level. Changes in ownership occur quite often, especially among the larger agencies. Among this subsample, in 21 percent of the firm-year observations a change in ownership took place, against 12 percent within the set of smaller firms. This implies that 52 percent of the large firms and 35 percent of small agencies has experienced at least one ownership change during the time period they are included in the sample. In addition, large agencies show, on average, more changes in their board composition, compared to the small firms (48 versus 21 percent of firm year observations, and at least one change in 72 and 56 percent, respectively). Since their management teams are, generally, larger as well, this finding is not surprising. In 4 percent of the entire sample of firm-year observations a name change occurs, the percentage being 3 percent among small and 5 percent among large firms. That is, 17 and 7 percent of large and small firms changed their name at least once during the period. Onlly one percent of the observations, both within the set of small and large agencies, represents a removal from one city to another, meaning that at the firm level, respectively 3 and 4 percent of the group of small and large firms has moved to another city between 1984 and 1994 .

The correlation matrix is presented in Table 4.3. The matrix reveals many significant correlations. For instance, as could be expected, the three indicators of firm size, i.e, income, staff and board size, are positively and highly related. 


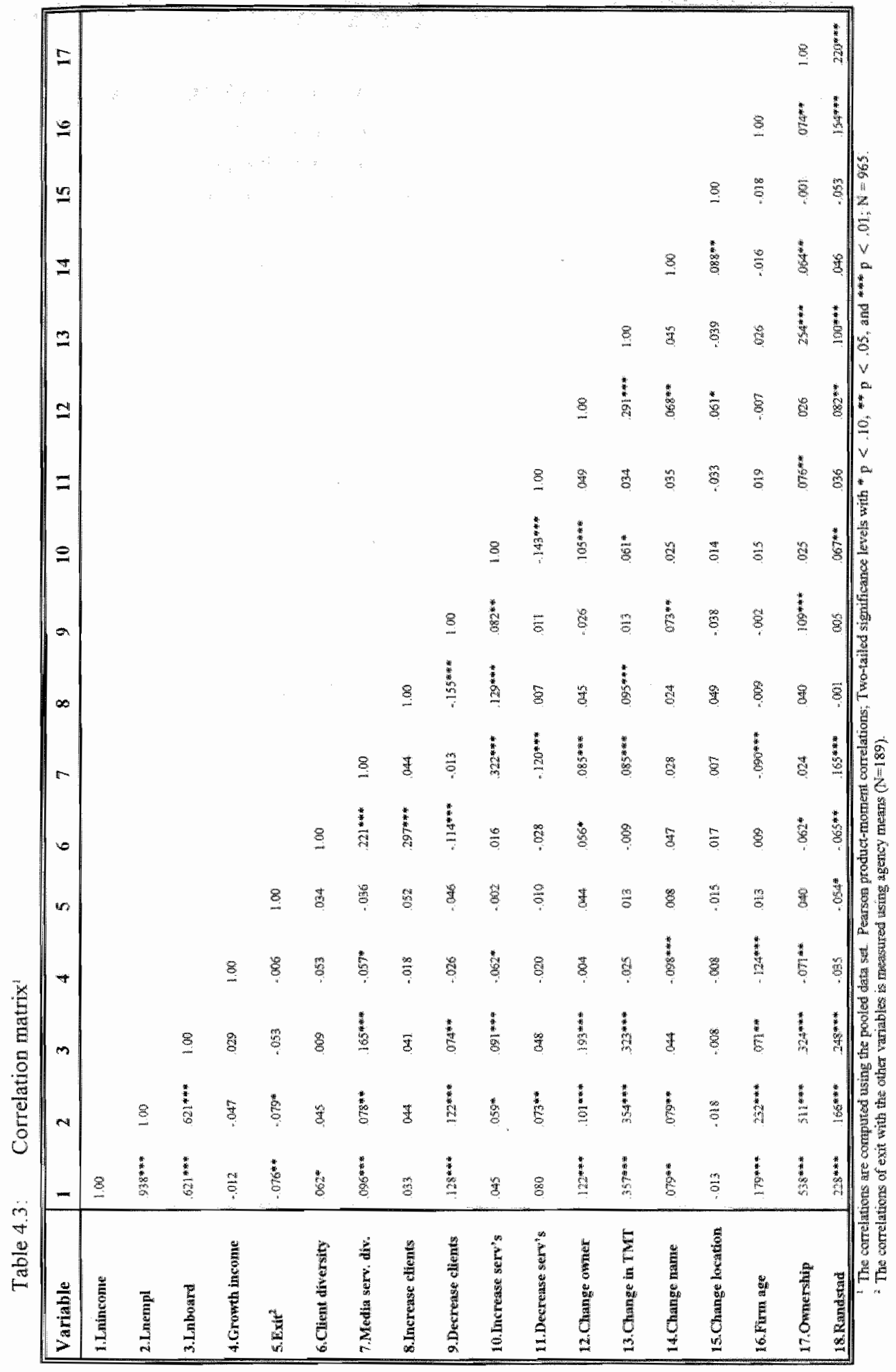


Furthermore, diversity in clients and media services appear to be related. The absolute diversity in clients and services are both significantly connected to changes in these diversity measures. This is not surprising, since augmenting diversity compared to the previous year implies a higher index in the current year and, vice versa, a decline in the index means a lower index in the present year

Changes in ownership are associated with changes in top management team composition The logic of this correlation may be illustrated by two examples. First, when an internal or external manager becomes a partner, (s)he, generally, is or becomes a board member as well Second, in the case of a merger, generally, both the ownership structure as well as the composition of the top management team undergoes a modification.

The observation that name changes are linked with ownership changes and a decrease in clients was expected since names of advertising firms are often made up of the initials of the owners or refer to strategic positions. However, both correlations are rather low, indicating that these are not the only reasons to change a firm's name. Agencies (partly) owned by a large multinational advertising firm experience significantly more changes in the composition of the board compared to agencies uniquely owned by their directors. This observation is easily explained by the fact that (i) multinationally owned agencies are large agencies with large boards, implying more change opportunities and (ii) a larger proportion of the board members does not own stakes in the agency, which makes switching from one agency (board) to another rather easy.

Advertising firms located in the Randstad appear to be significantly more specialized in terms of clients but more diversified in terms of services, compared to agencies seated in other regions of the Netherlands. The first observation, that specialization of clients is higher in the Randstad, may be the result of the fact that in this region the density of agencies ànd advertisers is high. This makes specialization possible but probably also necessary since, in order to distinguish one's agency from other firms, a clear market positioning is required. The fact that agencies in the Randstad are more diversified in terms of media services than firms outside this region, is probably caused by the observation that specialization in clients makes the delivery of a wide range of media services necessary.

Finally, the argument that ownership and top management team changes have an impact on firm performance through their influence on strategic positioning, receives some support from the correlation analysis in the present sample. Changes in ownership appear to imply modifications in the diversity of media services (both increases and decreases) and moving to another city. Top management team mutations go hand in hand with increases in the client and media services portfolio. 


\subsubsection{Organizational change and agency performance}

This section presents the results of the analyses that test the effect of core and peripheral change on agency performance. The results are summarized subsequently with respect to income, income growth and the probability of failure. Table 4.4 and Table 4.5 summarize the results of the fixed-effects estimates concerning the effect of organizational change on income and income growth, respectively. Table 4.6 presents the findings of the analyses with respect to the probability of failure. For small and large firms separately, two models are estimated. The first regression includes control variables onlly. The second model adds the organizational change variables to the equations. Each table shows the outcomes of the regressions for small agencies in columns (1) and (2), while the results of the two models for large agencies are replicated in columns (3) and (4).

\subsubsection{Organizational change and firm income}

Table 4.4 presents the results of the analyses testing the effect of organizational change on firm income. Table 4.4 indicates that there are decreasing returns to scale in this industry. Furthermore, given the size of the firm, the board size is positively connected to firm income. Additional top executives enhance income, or fewer board members decrease firm revenues, ceteris paribus, both among small and large firms. Small agencies obtain a significantly higher income, all other things equal, when seated in the Randstad than in other regions of the Netherlands. In addition, columns (1) and (3) show that client diversity positively affects the income of small agencies whereas service diversity tends to be negatively related to the financial performance of large advertising firms. These results imply that diversification in terms of clients is beneficial for small firms, whilst specialization in terms of media services enhances large agencies" output. Adding organizational change variables to the equation (model 2), significantly increases the explained variance within the subsample of small firms, though not for large agencies ( $F=2.40$ and $F=.257$, respectively).

Hypothesis 1, and 2, expecting, respectively, a negative impact of change in client diversity and media service diversity on advertising firm performance, are not supported by the results (see columns (2) and (4)). Both increases and decreases in the two diversity measures appear to be unrelated to agency income, both for small and large firms. Additionally, in order to test Hypotheses 1 and 2, for both sets of agencies, Model 2 (in columns (2) and (4)) has been reestimated using the lagged client and service diversity measures (see Haveman, 1992). However, the analyses generated identical outcomes as those presented in the table, i.e., the changes in the diversity measures remain insignificant and keep the same sign. Hypothesis 3 , expecting a negative relationship between a change in ownership structure and performance, is not supported by the findings either. Ownership changes appear to be unrelated to agency performance. 
Table 4.4: The effect of organizational change on firm incomes

\begin{tabular}{|c|c|c|c|c|}
\hline & \multicolumn{2}{|c|}{ Small agencies } & \multicolumn{2}{|c|}{ Large agencenes } \\
\hline & Control varables & $\begin{array}{l}\text { Control } \\
\text { and onganizinonal } \\
\text { change vars's }\end{array}$ & Conteroll wriables & $\begin{array}{c}(4) \\
\text { Coutrol } \\
\text { and organ } \\
\text { changetional } \\
\text { vars's }\end{array}$ \\
\hline Lial(emilit) & $\begin{array}{c}619 \% * \\
(.071)\end{array}$ & $\begin{array}{l}6001 \mathrm{~m} \text { (n) } \\
0071)\end{array}$ & $\begin{array}{l}.650 \mathrm{m**} \\
6,0318)\end{array}$ & $\begin{array}{l}653^{* * *} * \\
60397\end{array}$ \\
\hline Lar(board) & $\begin{array}{l}.088^{*}: * \\
(0411)\end{array}$ & $\begin{array}{l}.066 \\
0.041)\end{array}$ & $\begin{array}{l}.065 \mathrm{HA} \\
(.021)\end{array}$ & 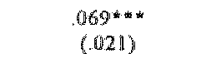 \\
\hline $\begin{array}{l}\text { Owntersibi } \\
\text { large ingency }\end{array}$ & $\begin{array}{l}.122 \\
(.118)\end{array}$ & $\begin{array}{l}081 \\
(115)\end{array}$ & $\begin{array}{l}.048 \\
(032)\end{array}$ & .046 \\
\hline Randstidt & $\begin{array}{l}86]^{*} \\
(134)\end{array}$ & $\begin{array}{l}(132) \\
(13 * * *\end{array}$ & - & . \\
\hline Client allwarsilty & $\begin{array}{l}.037^{* *} \\
(018)\end{array}$ & $\begin{array}{l}.0058 * * * \\
(022)\end{array}$ & $\begin{array}{l}-010 \\
(0008)\end{array}$ & $\begin{array}{l}., 009 \\
(009)\end{array}$ \\
\hline Servite diwersity & $\begin{array}{l}.013 \\
(044)\end{array}$ & $\begin{array}{r}.034 \\
(054)\end{array}$ & $\begin{array}{l}-.042 * \\
(.022)\end{array}$ & $\begin{array}{l}-.051^{\text {10 }} \\
(029)\end{array}$ \\
\hline $\begin{array}{l}\text { lacreases in client } \\
\text { diversity }\end{array}$ & & $\frac{.036}{(024)}$ & & $\begin{array}{l}-.001 \\
(012)\end{array}$ \\
\hline $\begin{array}{l}\text { Decreane in elient } \\
\text { iljwersity }\end{array}$ & & $\begin{array}{l}.038 \\
(.039)\end{array}$ & & $\begin{array}{l}-.602 \\
(014)\end{array}$ \\
\hline $\begin{array}{l}\text { Inicreane in } \\
\text { service diversity }\end{array}$ & & $0.063)$ & & $\begin{array}{l}.007 \\
60367\end{array}$ \\
\hline $\begin{array}{l}\text { Deerease in } \\
\text { storvice diversity }\end{array}$ & & $\begin{array}{l}-.056 \\
(070)\end{array}$ & & $\begin{array}{r}-019 \\
(039)\end{array}$ \\
\hline $\begin{array}{l}\text { Change } \\
\text { ownership }\end{array}$ & & .0072 & & $\begin{array}{c}.013 \\
(017)\end{array}$ \\
\hline $\begin{array}{l}\text { Change in TMTl } \\
\text { compissition }\end{array}$ & & $\begin{array}{l}1002 \ldots+k \\
(032)\end{array}$ & & $\begin{array}{l}-.017 \\
(0.14)\end{array}$ \\
\hline $\begin{array}{l}\text { Change of lowenton } \\
\text { (to other vify) }\end{array}$ & & $\begin{array}{l}.121 \\
(105)\end{array}$ & & $\begin{array}{l}-006 \\
0.068)\end{array}$ \\
\hline Chatage in thate & & $\begin{array}{l}.026 \\
(048)\end{array}$ & & $\begin{array}{l}.015 \\
(.032)\end{array}$ \\
\hline Adj. $\mathrm{R}^{2}$ & .820 & 828 & .969 & .969 \\
\hline$r\left(\Delta M^{\prime}\right)$ & & $240 *$ & & $25 \%$ \\
\hline N firmus & $7 s$ & 75 & 137 & 137 \\
\hline $\mathrm{N}$ & 34 & 341 & 624 & 6.24 \\
\hline
\end{tabular}

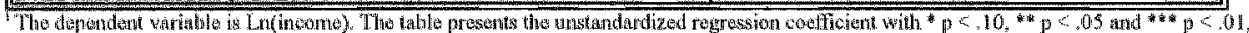

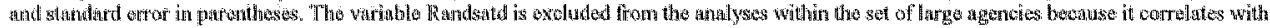
the fint dummess so producing multicoll inearity.

For Hypothesis 4, predicting a negative effect of top management team mutations on agency performance, contradicting evidence is obtained within the set of small advertising agencies. Opposite to the expectation, small firms' income increases significantly subsequent to a change in the composition of their boards. The expected positive effect of changes in name and 
location, i.e, peripheral features of agencies, on firm performance captured in Hypohesis 5 and 6 , has not been reproduced by the analyses. The two changes are not connected to advertising firm income. Finally, the outcomes presented in Table 4.4 provide weak support for Hypothesis 7, predicting a more pronounced effect of core and peripheral changes on small agencies" than on large agencies" performance. That is, the only significant finding that is obtained in these analyses, although in the opposite direction, concerns small advertising companies.

\subsubsection{Organizational change and agrency growth}

Table 4.5 summarizes the impact of organizational change on firm growth. Columns (1) and (3) of Table 4.5 point out that growth rates decrease with firm size, which is consistent with the findings reported in Chapter 3, theory and prior research. Furthermore, among large agencies, growth rates are positively related to the size of the board. Either more top executives enhance growth rates or fewer managers decrease firm growth. For small firms, location in the Randstad positively affects agency growth. The degree of client and media service diversity are unrelated to the growth rates of advertising agencies. F-tests indicate that adding the organizational change variables to the analyses (model 2) significantly increases the explained variance for small agencies $(F=2.44)$, though not for large agencies $(F=1.79)$.

Hypothesis 1, predicting a negative connection between change in client diversity and performance, is not supported by the results. Changes in this core feature, i.e., either increases or decreases, appear to be unrelated to agency growth. Hypothesis 2, expecting a negative linkage between change in media service diversity and performance, is partly confirmed by the findings. In accordance with the Hypothesis, there is a tendency among small firms for decreases in media service diversity to diminish growth rates $(p<10)$. Hypothesis 3 , foreseeing a negative relationship between changes in ownership stncture and performance, is not supported by the outcomes. The analyses produce no evidence for a connection between this core change and agency growth rates.

Contradicting evidence is obtained for Hypothesis 4, predicting a negative linkage between top management team mutations and performance, within the subsample of small agencies. Changes in the composition of the board positively affects small agency growth. This outcome parallels the result observed in Table 4.4 on the effect on firm income. Hypothesis 5, expecting a positive relationship between change in location and firm performance is partly contradicted by the findings. Opposite to Hypothesis 5 , small agencies' growth pace diminishes subsequent to a change of location. A change in location does not affect large advertising firms' growth pace. 
Hypothesig 6 , which predicted a positive effect of name changes on firm growth, appears to be confirmed for small agencies and contradicted for large advertising companies. Within the set of small agencies, a change in name tends to be followed by a relatively high growth rate.

Table 4.5: The effect of organizarional change on firm growth

\begin{tabular}{|c|c|c|c|c|}
\hline & \multicolumn{2}{|c|}{ Small agenties } & \multicolumn{2}{|c|}{ Large agencies } \\
\hline & Contuel yatiables & $\begin{array}{c}\text { (2) } \\
\text { Control } \\
\text { and organtathoul } \\
\text { change vares }\end{array}$ & (3) & $\begin{array}{l}\text { Control } \\
\text { and organizational } \\
\text { change var } r^{*} s\end{array}$ \\
\hline 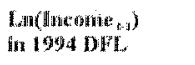 & $\begin{array}{c}-24.5 \% \\
0.035)\end{array}$ & $\begin{array}{l}. .25 \mathrm{~m} \mathrm{~mm} \\
(.035)\end{array}$ & $\begin{array}{c}-.325 * * * \\
(.029)\end{array}$ & $\begin{array}{c}-932^{\alpha+*} \\
(.029)\end{array}$ \\
\hline Lar(monaril) & .034 & $\begin{array}{l}.040 \\
(.033)\end{array}$ & $\begin{array}{l}.094^{* n+1 \pi} \\
(021)\end{array}$ & $\begin{array}{l}.0886^{\mathrm{m} * *} \\
(.021)\end{array}$ \\
\hline $\begin{array}{l}\text { Omanership } \\
\text { lurget agency }\end{array}$ & $\begin{array}{l}-0.38 \\
0.092)\end{array}$ & $\begin{array}{r}.069 \\
0.092)\end{array}$ & $\begin{array}{l}.035 \\
(.034)\end{array}$ & $\begin{array}{l}.026 \\
(.034)\end{array}$ \\
\hline Randstad & $\begin{array}{l}256 * * \\
(.105)\end{array}$ & $\begin{array}{l}.251 * * \\
(103)\end{array}$ & - & . \\
\hline Client diversity & $\begin{array}{l}.022 \\
(.014)\end{array}$ & $\begin{array}{l}.024 \\
(017)\end{array}$ & $\begin{array}{l}.007 \\
0.008)\end{array}$ & $\begin{array}{l}.012 \\
(.009)\end{array}$ \\
\hline Serwice diversily & $\begin{array}{l}.015 \\
(.037)\end{array}$ & $\begin{array}{c}.061 \\
(043)\end{array}$ & $\begin{array}{r}-.023 \\
(.023)\end{array}$ & $\begin{array}{l}.006 \\
(.030)\end{array}$ \\
\hline $\begin{array}{l}\text { Increase ho cllent } \\
\text { diwersity }\end{array}$ & & $\begin{array}{c}.010 \\
(020)\end{array}$ & & $\frac{.008}{(012)}$ \\
\hline $\begin{array}{l}\text { Decresse in client } \\
\text { diwessityy }\end{array}$ & & $\begin{array}{l}-017 \\
(.031)\end{array}$ & & $\begin{array}{r}.016 \\
(.014)\end{array}$ \\
\hline $\begin{array}{l}\text { Hucrease in } \\
\text { servidae diversity }\end{array}$ & & $\begin{array}{l}-.097 \% \\
(.054)\end{array}$ & & $\begin{array}{l}-.034 \\
(.036)\end{array}$ \\
\hline $\begin{array}{l}\text { Decrnase fin } \\
\text { service diverialy }\end{array}$ & & .002 & & $\begin{array}{c}.052 \\
(.039)\end{array}$ \\
\hline 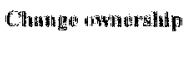 & & $\begin{array}{l}.043 \\
(033)\end{array}$ & & $\begin{array}{l}.005 \\
(.018)\end{array}$ \\
\hline 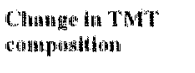 & & $\begin{array}{l}.066 * 16 \\
0.026)\end{array}$ & & $\begin{array}{l}.013 \\
(.015)\end{array}$ \\
\hline 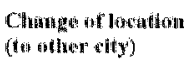 & & $-200 *$ & & $\begin{array}{c}.040 \\
(.069)\end{array}$ \\
\hline chlowhige in wame & & $\frac{128 *}{0.076)}$ & & $\begin{array}{c}-.023 \\
(.032)\end{array}$ \\
\hline Att]. $R^{3}$ & .396 & .426 & .397 & .405 \\
\hline$F\left(\Delta \mathbb{R}^{3}\right)$ & & $2.44 * *$ & & 1.79 \\
\hline N thims & 66 & 66 & 194 & 134 \\
\hline$N$ & 304 & 304 & 616 & 616 \\
\hline
\end{tabular}

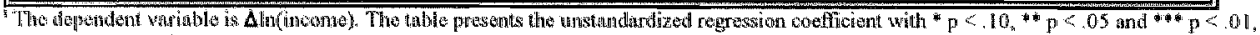
and stundind error is parenthuses. 
However, contrary to Hypothesis 6, large firms" growth pace declines ais a result of a name change. Finally, the findings provide, in balance, evidence for Hypothesis 7 , predicting a more pronounced effect of core and peripheral changes on the performance of small agencies compared to large advertising firms. Within the set of small agencies, two core changes and two peripheral feature changes are significantly related to agency growth, whilst only one signifcant impact of change on growth is observed for large firms.

\subsubsection{Organizational change and agency failure}

The ou tcomes of the analyses testing the influence of organizational change on the probability of failure are presented in Table 4.6. Columns (1) and (3) point out that, contrary to the results in Chapter 3, agency size is not significantly related to the probability of failure. While the coefficient has the expected negative sign, the relationship is not significant. Additional analyses, not reflected in the table, indicate that controlling for board size, which was not controlled for in Chapter 3 , turns the coefficient insignificant. Firm age appears to be unrelated to survival chances, which corresponds with the results obtained in Chapter 3. Small agencies' chances of failure tend to increase with additional board members and specialization in media services. That is, small advertising firms exiting the sample before the end of the time period were, during the pre-exit years, characterized by a relatively large board and a specialized media services portfolio. Location inside or outside the Randstad and client diversity do not affect small firms' survival chances. None of the control variables influences large agencies” probability of survival.

Columns (2) and (4) show that none of the core and peripheral change variables under study significantly influences the probability of failure of small and/or large advertising agencies. Hypothesis 1 - 7 are, thus, not supported by the results. Repeating the analyses with the sum of the changes in client diversity and service diversity (instead of agency means), does not gener. ate significant findings either. Clearly, organizational core and peripheral changes, as measured in this study, do not affect advertising tirms " probability of exit. 
Table 4.6. The effect of orgawizational change on firm failure"

\begin{tabular}{|c|c|c|c|c|}
\hline & \multicolumn{2}{|c|}{ Small ageracies } & \multicolumn{2}{|c|}{ Large agencies } \\
\hline & $\begin{array}{l}\text { (1) } \\
\text { Control vartables: }\end{array}$ & $\begin{array}{c}\text { Control } \\
\text { and organzutional } \\
\text { chlunge var"s }\end{array}$ & $\begin{array}{c}\text { (3) } \\
\text { Control wariables }\end{array}$ & $\begin{array}{c}\text { (4) } \\
\text { Control } \\
\text { and organizationall } \\
\text { change var"s }\end{array}$ \\
\hline 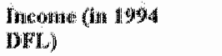 & $\begin{array}{l}.434 \\
(.253)\end{array}$ & $\begin{array}{l}-.187 \\
(0.099)\end{array}$ & $\begin{array}{l}-.354 \\
(.233)\end{array}$ & $\begin{array}{l}-329 \\
(245)\end{array}$ \\
\hline Gorard stue & $\begin{array}{l}.840^{*} \\
(.467)\end{array}$ & $\begin{array}{l}1.0477 \\
(.980)\end{array}$ & $\begin{array}{r}.138 \\
(.301)\end{array}$ & $\begin{array}{r}-300 \\
(352)\end{array}$ \\
\hline Firm aty & $\begin{array}{l}.006 \\
(.029)\end{array}$ & $\begin{array}{l}051 \\
0.037)\end{array}$ & $\begin{array}{l}.007 \\
(.016)\end{array}$ & $\begin{array}{r}-.005 \\
(.016)\end{array}$ \\
\hline $\begin{array}{l}\text { Onthictifis } \\
\text { Harge anency }\end{array}$ & - & " & $\begin{array}{c}.199 \\
(.916)\end{array}$ & $\begin{array}{l}371 \\
(997)\end{array}$ \\
\hline Romdistud & $\begin{array}{r}.218 \\
(.719)\end{array}$ & $\begin{array}{l}.360 \\
(.980)\end{array}$ & $\begin{array}{r}-.025 \\
(.625)\end{array}$ & $\begin{array}{r}.237 \\
(735)\end{array}$ \\
\hline Cliternt diversity & $\begin{array}{r}.082 \\
(230)\end{array}$ & $\begin{array}{c}.393 \\
(.329)\end{array}$ & $\begin{array}{l}207 \\
(.251)\end{array}$ & $\begin{array}{c}201 \\
(.266)\end{array}$ \\
\hline Sorvico diversity & $\begin{array}{c}-1.490 \\
(.794)\end{array}$ & $\begin{array}{l}-1.665 \% \\
(1.005)\end{array}$ & $\begin{array}{l}.408 \\
(.616)\end{array}$ & $\begin{array}{l}.330 \\
(.659)\end{array}$ \\
\hline Ne of years in sample & $\begin{array}{l}.013 \\
(1136)\end{array}$ & $\begin{array}{l}-357 \\
(273)\end{array}$ & $\begin{array}{l}-.032 \\
(.154)\end{array}$ & $\begin{array}{l}.156 \\
(.211)\end{array}$ \\
\hline $\begin{array}{l}\text { Intreatse in cllent } \\
\text { diwersity }\end{array}$ & & $\begin{array}{l}-1.106 \\
(1.255)\end{array}$ & & $\begin{array}{l}-1.485 \\
(1.277)\end{array}$ \\
\hline $\begin{array}{l}\text { Decresses in alient } \\
\text { diwersity }\end{array}$ & & $\begin{array}{c}3.797 \\
(2.977)\end{array}$ & & $\begin{array}{c}1.053 \\
(1.485)\end{array}$ \\
\hline $\begin{array}{l}\text { Increatse in } \\
\text { servive diversity }\end{array}$ & & $\begin{array}{r}-1.406 \\
(4.453)\end{array}$ & & $\begin{array}{c}-213 \\
(3.585)\end{array}$ \\
\hline $\begin{array}{l}\text { Decreasu in } \\
\text { service divarsity }\end{array}$ & & $\begin{array}{c}6.554 \\
(7.289)\end{array}$ & & $\begin{array}{c}-1.424 \\
(3.739)\end{array}$ \\
\hline $\begin{array}{l}\text { C7wanger } \\
\text { owwitershing }\end{array}$ & & $\begin{array}{l}.093 \\
(.557)\end{array}$ & & $\frac{584}{(980)}$ \\
\hline 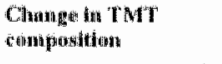 & & $\begin{array}{l}465 \\
(406)\end{array}$ & & $\begin{array}{l}.029 \\
(307)\end{array}$ \\
\hline 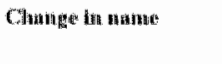 & & $\begin{array}{c}924 \\
(1.338)\end{array}$ & & $\begin{array}{r}., 390 \\
(.783)\end{array}$ \\
\hline $\begin{array}{l}\text { change of locetion } \\
\text { (to nither cet } y \text { ) }\end{array}$ & & $\begin{array}{c}11.889 \\
(36.884)\end{array}$ & & $\begin{array}{c}.6 .337 \\
(22.537)\end{array}$ \\
\hline 2 l.we wilkg thowd & 72.970 & 56.5018 & 87.905 & 81.736 \\
\hline-2 log likellihood & & -16.462 & & -46.175 \\
\hline$N$ & 75 & 75 & 137 & 137 \\
\hline
\end{tabular}

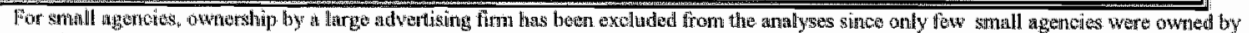

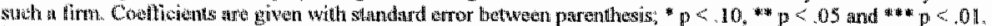

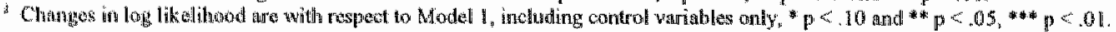




\subsection{Discussion}

The results of the analyses are summarized in Table 4.7

\section{Table 4.7: Summary of results}

\begin{tabular}{|c|c|c|c|c|c|}
\hline \multirow[t]{2}{*}{ Hypothesis: } & \multirow{2}{*}{\multicolumn{2}{|c|}{ Prediction }} & \multicolumn{3}{|c|}{ Restilts } \\
\hline & & & Income & Growwh & Siwnthent \\
\hline \multicolumn{6}{|l|}{ Strategy - Performance } \\
\hline \multirow[t]{2}{*}{ * Client diversity } & & Small agenoies & +4 & ns & $\mathrm{ns}$ \\
\hline & & Large agenoles & nss & $\mathrm{n} s$ & $n$ is \\
\hline \multirow[t]{2}{*}{ * Media service diversity } & & Small agencies & nis & $\mathrm{ns}$ & * \\
\hline & & Large agemcies & - & $\mathrm{nx}$ & $n$ \\
\hline \multicolumn{6}{|l|}{ Cone change - Perforrtance } \\
\hline \multirow[t]{2}{*}{ 1a. merease client diversity } & * & Srrall agencies & $n s$ & $n s$ & 115 \\
\hline & & Large angeneies & $n s$ & ns & tis \\
\hline \multirow[t]{2}{*}{ 16. Decrease olient diversity } & - & Small angenaies & $\mathrm{n}, \mathrm{s}$ & ns & nss \\
\hline & & Large agencies & ns & $\mathrm{ng}$ & ns \\
\hline \multirow{2}{*}{$\begin{array}{l}\text { 2a. Inctease media sicrvice } \\
\text { diversity }\end{array}$} & - & Small agencies & nis & 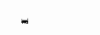 & ns: \\
\hline & & Large agencies & nss & ns & mes \\
\hline \multirow{2}{*}{$\begin{array}{l}\text { 26. Deerease media service } \\
\text { diversity }\end{array}$} & . & Stnall agernuies & Ins & $\mathrm{ns}$ & ns \\
\hline & & Lange agencies & ns & his & $\mathrm{ns}$ \\
\hline \multirow[t]{2}{*}{ 3. Change in ownersinip } & * & Simall agencies & ns & $\mathrm{tw}$ & 月星 \\
\hline & & Large ageneies & this & ns & n:s \\
\hline \multirow[t]{2}{*}{ 4. Charge TMT composition } & - & Small agencies & + & + & nis \\
\hline & & Large agencies: & ms & ns & m16s \\
\hline \multicolumn{6}{|l|}{ Peripheral change - perfornance } \\
\hline \multirow[t]{2}{*}{ 5. Change in location } & + & Sratall agencies & ns & - & not lesterd \\
\hline & & Large agencies & $\mathrm{ng}$ & riss & $n$ \\
\hline \multirow[t]{2}{*}{ 6. Change in rame } & + & Small angencies & ndis & + & 助数 \\
\hline & & L.apge agencius & N13 & • & 月1: \\
\hline 7. Interaction of size & - & & $\therefore$ & . & ns \\
\hline
\end{tabular}

Several things strike the eye. First, organizational change is most often significantly related to income growth; only one change variable is significantly linked to firm revenues and none of the changes under study is significantly related to survival chances. Second, the absolute levels of diversity in clients and media services have a stronger significant relationship with firm performance than changes in these strategic positions. Third, changes in organizational core features have no effect on large firms' performance, but two out of six organizational core transformations affect small agencies" financial performance. Fourth, the impact of core and peripheral feature changes are, in two cases, not in the predicted direction. Fifth, and finally, as expected, organizational changes are more often significantly related to small agencies' than 
large firms performance.

The finding that agency income is less frequently significantly affected by organizational change than growth rates may be due to the effect of time. While growth rates may be modified rather easily, it may take more to affect productivity. Firm imcome may be influenced only several years after a transfornation has been carried through. That the impact of change may not be significant for survival chances may have several reasons. First, because the changes are not severe enough. That is, either organizational core change is not connected to survival (contrary to ecology theory), or the selected changes are not well chosen. Second, the sample is biased toward the financially healthy organizations, so underestimating the possible negative linkages with survival chances. And third, the operationalization of failure in terms of exil from the sample may have been unfortunate. Finally, as pointed out by Boone and Van Witteloostuijn (1995), organizational survival and financial performance may not be intertwinable measures of performance: the two performance measures may be affected in different ways. This is easily recognized in the observation that survivors are not always very profitable organizations (Van Witteloostuijn, 1996). Unprofitable survivors may exist, and so may profitable failers. In the adaptation perspective no clear distinction is made between financial performance and survival chances, whereas in organization ecology theory financial performance measures are underemphasized. Considering the results of the current study, in theory, a distinction should be made as to the effect of organizational change on financial performance and survival chances.

The results indicate that the absolute level of client portfolio and media service diversity have a stronger significant impact on firm performance than mutations in these strategic positionings. The insignificant effects of transformations in the extent of client and media service diversity are probably due to the fact that the range of changes observed in these measures is rather small. Only very small mutations in the NE-indexes are reported. One can imagine that small changes in client and service portfolio fail to affect financial performance and survival chances of agencies. It may well be the lack of large modifications in the diversification measures that explains the absence of a significant relationship with performance. A change from serving many categories of clients to specialization in a few sorts of customers will probably have a more pronounced impact on performance. However, the absence of such drastic transformations is probably caused by the fact that agencies work on order, not on stock. Clients are attracted by the range of customers currently served and services presently provided. It will, for instance, rarely happen that, within one year, a specialized agency obtains several large accounts of client categories it has never worked for before, drastically affecting its strategic stance into a diversified positioning.

Opposite to the predictions, changes in top management team composition have a positive impact on small agencies' financial performance (income and income growth). While prior 
research findings on leader succession and financial performance are mixed (see e.g., Lieberson and $O^{\prime}$ Connor, 1972; Beatty and Zajac, 1987 and Schreuder, 1993), for the Dutch advertising industry a negative effect was expected. One possibility for the positive linkage is the fact what in the present study change in top management team composition rarely refers to the total replacement of the board. Perhaps, when only one or few managers are added to leave or are replaced from a team, this may positively infuence the attraction of new clients and/or the continuation of existing agency - client relationships, so enhancing subsequent performance. Furthermore, it is possible that a top management team mutation is disruptive when it involves. the CEO, but beneficial when it concerns other top executives. Unfortunately, we do not dispose of the necessary data to test this suggestion. That the effect of top management team mutations is not significant within large firms is consistent with the argument that in large companies succession has become a bureaucratic event (Grusky, 1961). Nevertheless, differentiation to various forms of board change may provide additional insight into this issue.

Contrary to the prediction, small agencies' financial performance (growtl) is harmed by a removal to another city. The negative impact for small companies is explained by the argument that especially small agencies need to be located near advertisers. For these firms, location may represent a core strategic issue, instead of a peripheral feature. When small firms move, the possibility exists that current clients located in the former city will end the relationship. For small advertisers, closeness may be an important agency selection and switching criterion. For large advertisers, location probably plays a smaller role in both processes. However, other explanations may also be advanced. But more information on the location change seems necessary to fully understand the implications. For instance, what are the reasons for change. Maybe small firms move to another city in order to be located closer to their present clients, or because they believe more potential clients reside in that region. And, is there a difference in the distance of the removal between small and large firms, or in direction, that is, do large firms move to the Randstad, the region where agency income appears to be higher than elsewhere? Both arguments coulc also explain the positive and negative effects for large and small agencies, respectively. In future research this can be investigated with the current (rough) data set, as is true also for some of the other issues raised.

Finally, the negative effect of a name change on large agencies' short-run financial performance contradicts the expectation, but is not surprising. A change in name may harm an agency"s stable reputation, so confusing potential clients in the short run, and thus decreasing financial performance. In the long run, however, the changes associated with the change in name may prove beneficial. Furthermore, the different findings between small and large firms may be due to different causes of name changes. Name changes are external expressions of internal organizational transformations, and with the use of a dummy variable different categories of underlying modifications are treated as similar. Additional information on the underlying 
causes of name changes could explain the unexpected outcomes.

This study points out that the relationship between organizational change and performance may differ between small and large firms. For instance, a management team mutation significantly enhances small agencies" income and income growth rates but is unrelated to the performance of large agencies, and a change in name has a significant positive effect on small agencles' revenue growth, but a negative impact on the income growth of large firms. As predicted, the impact of organizational transformations is more often significant with respect to small firms" than large agencies" performance. Large firms may have a greater buffer against consequences of organizational change and/or the effect of core changes may affect the performance of large agencies only several years later.

While it seems to be a good idea to select core and peripheral organizational features on the basis of industry contingencies (e.g., top management team compostion and firm location), the results of the present study suggest that operationalization of changes in these characteristics in terms of dummy variables is not sufficient to predict their effect on performance. It is important to use well specified change wariables, as explained previously with respect to, e.g., top management team mutations and remowal to another city.

Whereas several core and peripheral changes have a significant negative impact on agency performance, the operationalization of the changes in terms of dummy variables and the lack of substantial changes (in diversification) may be blamed for the fact that not more significant outcomes are obtained. In addition, the sample is biased toward the financially healthy organizations, which may also imply that the results underestimate the (negative) linkages. Another point is that the applied analyses, fixed-effects estimates and logistic regressions over agency means, constitute very conservative tests of the hypotheses. Fixed-effects analyses have also been used in previous research on organizational change and financial performance (see, eg. Haveman, 1992). These analyses model only within-firm variation. While these analyses indicate whether and how, within firms, organizational change affects performance ${ }_{x}$ they give no insight into the question whether firms that have carried through a larger number or more severe changes perform better than their conservative counterparts. The logistic regressions carried out in this study do not take account of the time aspect. Unfortunately due to data limitations analyses that do, such as event history analyses, could not be undertaken. Finally, one may argue that organizational changes need time to work through in the firm, thus having an impact on financial performance one (or several) years later only. If large firms are more inert, it is possible that the effect of organizational change on perfomance is reflected later in the performance of large than small organizations. In future analyses, therefore, (i) only organizational features that indeed undergo drastic changes should be selected, (ii) dummy variables should be avoided, (iii) the analyses may be extended by those that pay attention to between-firm variation and the time-aspect and (iv) the lagged effect of organizational change 
on performance should be examined as well.

\subsection{Conchusilons}

This study examined the effect of organizational core and peripheral changes on three measures of performance, separately among small and large advertising firms. The results suggest that the three performance indicators are influenced by different organizational change processes. The organizational changes investigated in this study are more often significantly related to advertising growth rates than to firm income. The effect is never significant for survival chances. The findings also reveal that the effect of transiormations may differ for small and large companies; the performance indicators of small advertising agencies are more frequently significantly affected by organizational changes than those of large agencies. While. removal to another city and increases in media service diversity have a negative impact on small adventising companies" financial results, mutations in top management team composition and name changes positively affect small agencies" financial outcomes. Large agencies" growth rates decline subsequent to name changes. Increases and decreases in client and service diver sity and ownership changes have, as measured in this study, no consequences for firm performance.

The lack of more significant outcomes may be due to (i) the operationalization of the changes in terms of dummy variables, (ii) the lack of substantial changes in certain variables (e.g., in diversification), (iii) the sample bias toward the financially healthy organizations, (iv) the severeness of the applied analyses and $(v)$ the use of the proxy of failure by exit from the sample. Indeed, in future analyses these points should be taken into account. 


\section{CHAPTER 5}

\section{MANAGEMENT CAPITAL AND BUSINESS SUCCESS}

\subsection{Introduction}

Top executives" personal characteristics, such as their age, tenure, level of education and functional background, are suggested to be important factors in determining firm outcomes. Prior research has shown that managers" features influence organizational innovation (Hage and Dewar, 1973), structure (Miller and Toulouse, 1986), strategy (Boeker, 1989), survival (Hambrick and D'Aveni, 1992) and growth (Eisenhardt and Schoonhoven, 1990). Two streams of research that have been concerned with the effect of top managers" characteristics on organizational outcomes are human capital theory (Becker, 1964) and, more recently, upper echelon theory (Hambrick and Mason, 1984). The former theory advocates the positive impact of knowledge and skills on productivity, and the latter model argues that organizational outcomes, both strategies and effectiveness, are a reflection of top managers ${ }^{*}$ characteristics (Hambrick and Mason, 1984).

In assessing the (in)direct impact of top executives' personal attributes on firm performance, studies originating from human capital theory focused mainly on survival chances (see, e.g., Preisendörfer and Voss, 1990; Brüderl et al., 1992; Pennings et ail., 1997), whereas research inspired by the upper echelon model concentrated primarily on financial performance. While effects on the two performance indicators do not always converge, no study up to date has examined the impact of top managers' demographics on both performance measures within the same sample. Furthermore, while prior research has demonstrated that both the average level and the spread of characteristics among team members affect business success, whether and how these measures interact in their impact on firm performance has not yet been investigated. This study adds to the existing literature by addressing these two points. First, the effect of top management team characteristics is analyzed on both financial performance and survival chances. Second, not only the independent impact of average and spread of team attributes on performance is investigated, but the interaction effect of these team characteristics on firm outcomes is examined as well. The study is conducted in the Dutch advertising industry, a service industry in which the characteristics of top executives are expected to play a substantial role in explaining organizational performance. The study covers a time period of eleven years, $1984-1994$ 
The remaining part of the chapter is organized as follows. The next section presents the theoretical background and explains the purpose of the study. In Section 3 the theoretical links between demographic variables ${ }^{1}$ and organizational outcomes are discussed. Section 4 goes into the consequences of studying team effects. Section 5 gives an overview of prior research results on the topic. In Section 6 , the advertising industry specifics are described. Section 7 introduces the hypotheses. Section 8 involves the methods, and Section 9 presents the results of the study. The chapter ends with a discussion and some concluding remarks in Section 10 and 11 , respectiwely.

\subsection{Theory and purpose of the study}

One of the early theories stressing the importance of individual characteristics in explaining performance differences is grounded in human capital theory (Becker, 1964). According to human capital theory more skills and knowledge increase productivity (Becker, 1964; Mincer, 1974). A distinction can be made between general and specific human capital (Becker, 1975). General human capital usually designates the number of years of schooling and the number of years of work experience (Brüderl et al, 1992). Specific human capital comprises industryspecific, entrepreneurial and firm-specific human capital (Preisendörfer and Voss, 1990; Pennings et al., 1997). Industry-specific human capital reflects experience in the industry in which the individual is currently employed. Entrepreneurial human capital, which is especially aimed at the future success of start-ups, points to the advantages of leadership and self-employment experience, and parental self-employment (Brüderl et al., 1992). Finally, firm-specific human capital indicates experience that is gained by working in a certain firm.

Traditionally, human capital theory and research focused on employees and their individual earnings (Becker, 1964; Bruderl et al, 1992). Only recently has the impact of human capital been transferred to the firm level, explaining variations in organizational performance. While initially the influence of the human capital of an individual, the founder or CEO, on company performance was examined (Bates, 1990; Preisendörfer and Voss, 1990; Bruderl et al., 1992; Boone and Van Witteloostuijn, 1996), lately few studies have been undertaken that investigate the human capital of groups of individuals at founding, i.e., owners and employees (Pennings et al., 1997) or personnel (Boone and Van Witteloostuijn, 1996), and subsequent organizational success. Inspired by human capital theory, and recognizing the importance of the individual, many studies have subsequently included one or several human capital variables in their analyses, without, however, referring explicitly to the framework of human capital theory in economics (Brüclerl et al, 1992)

\footnotetext{
In the following the terms demographic and human capital wariables are used ass subetitutes to rofer ta pertional charateristics.
} 
Human capital of workers is believed to enhance firm performance by providing the indiviwal with skills and experience that enable him/her to be more productive and to yield knowledge about profitable strategies (Becker, 1964; Bruderl et al, 1992). Higher productivity refers to a more efficient organization and management of the production process, and to the ability to attract more customers and new capital from investors (Bruderl et al., 1992). Especially in service industries, personal characteristics such as knowledge, education and skills of workers are important assets for attracting and retaining clients since the quality of services is difficult to assess (Bruderl et al. 1992; Pennings et al., 1997). The benefits of human capital reside at the individual level; hypotheses as to team effects grounded in human capital theory are, then, merely extensions of what is expected at the individual level, involving the average team the of personal attributes.

A tecent and more extended theory advocating the importance of personal characteristics in explaining organizational outcomes is proposed by Hambrick and Mason (1984). This model goes much further than human capital theory in several ways. First, the authors explicitly stress the importance of studying the team of managers instead of the chief executive only: "study of an entire team increases the potential strength of the theory to predict, because the chief executive shares tasks and, to some extent, power with other team members" (Hambrick and Mason, 1984: 196). Subsequent empirical research indicates indeed that the full team is a better predictor of organizational outcomes than the CEO alone (Finkelstein, 1988; Bantel and Jackson, 1989). Second, the spectrum of capital variables believed to affect organizational outcomes is extended with observable demographic characteristics, such as team tenure, functional and occupational background, and unobservable psychological characteristics, such as managers" values.

Third, and maybe most important, Hambrick and Mason (1984) argue that personal characteristics refer to certain values, attitudes and frames of reference which influence strategic decisions and by that means firm performance. This argument is grounded in the theorizing of scholars of the Carnegie School (March and Simon, 1958; Cyert and March. 1963). These theorists assume that people have bouncled rationalities, referring to their inability to comprehend all information that is available and relevant for taking decisions in complex environ ments. When taking decisions managers can impossibly process every relevant aspect of the organization and its environment. The manager's beliefs, knowledge, assumptions and values direct his/her attention towards certain aspects of the environment, and influences the way (s)he interprets the stimuli (Finkelstein and Hambrick, 1990; Boone et al., 1996). Each individual holds a set of values and has certain attitudes and perspectives which may be influenced by all kinds of experiences. Examples are the era in which the individual has been raised, the school system that (s)he has attended, the situation at the labor market at the time the individual entered (Murray, 1989; Boone et al. 1996), the specific education (s) he followed (Murray, 
1989) and the number of years worked in a specific industry and firm (Wagner at al., 1084) People are molded by their history, and perceive and interpret the world around them through the lenses of their experiences. This also concerns strategic decisions which are, therefore, argued to be influenced by these unobservable personal attributes. Studying observable demographic characteristics of managers is a way to overcome the problem of gaining information about the underlying personal values which are actually held responsible for the way people behave (Smith et al., 1994)

Finally, the upper echelon model not only stresses the importance of the average team level of demographic variables, but also underscores the effects of team composition in terms of the diversity of members' attributes. Fallowing psychological group literature, the extent of heterogeneity among team members is argued to determine group dynamics, which in turn affects team decisions and performance and, ultimately, organizational outcomes. Thus, not only the characteristics of individual nembers but, at least as important, the internal social team structure affects team functioning and thus firm outcomes (Gladstein, 1984; Goodman et al., 1987). The quality of information flows, the efficiency of cooperation and the motivation of team members, all determining company performance, are argued to be langely dependent upon the relations prevailing within the team (Hambrick and D'Aveni, 1992). The upper echeton theory has elicited a wide range of studies on the effect of top management team composition on firm outcomes. Some studies have examined the direct impact on organizational performance (Norburn and Birley, 1988); others have investigated the indirect association with firm performance through the mediation of, for instance, the match between strategy and environment (Miller, 1991) or communication and social integration (Smith et al., 1994). Several scholars have related top team composition to strategic choices such as innovation (Bantel and Jackson, 1989) and diversification (Wiersema and Bantel, 1992), and again others have associated top team make-up to affective consequences, e.g, absenteeism and turnover (Cuninings et al., 1993)

Both streams of literature, relating to human capital and upper echelon theory, have been ultimately concerned with the same research question, i.e., the influence of the personal characteristics of top managers on firm outcomes. In assessing the direct or indirect impact on organizational performance, human capital studies have concentrated mainly on firms" surwal chances, whereas studies in the upper echelon tradition have focused primarily on financial performance. However, as the review of the empirical studies below points out, the results with respect to survival chances and financial performance measures rarely coincide. In this respect, former research has revealed that financial indicators and survival are not necessarily related aspects of performance (Winter, 1964; Boone and Van Witteloostuijn, 1995; Chapter 4 of this book). Only studies that examine the impact of team demographics on the probability of survival and financial outcomes within the same sample may provide some insight into the 
differences in these relationships: The present study is a first attempt in this direction, and aralyzes the direct effect of team make-up on both firms" survival chances and financial performance. Furthermoite, prior research has demonstrated that the average level and diversity of texim characteristics both influence organizational outcomes. However; whether and how they interact in their impact on firm performance has not been investigated yet. Examination of the interaction effect of average and spread of team characteristics is the second intention of this study.

Since former research has not only pointed out that the distribution of personal characteristics in top teams differ across industries (Norburn and Birley, 1988) but also that the impact of the top management teams on performance may vary with the market (Murray, 1988), this study is carried out in a single industry. The Dutch advertising industry seems to be a suitable setting for studying the relationships at hand, since Dutch advertising agencies are rather small firms in which a telatively large part of the performance variation may be explained by the personal characteristics and preferences of their managers (Preisendorfer and Voss, 1990; Boone and Van Witteloostuijn, 1996).

\subsection{Top managers' demographics and organizational outcomes}

Three demographic variables are selected for this study: age, organizational tenure and industry experience. Age is one of the few universal and most salient human features providing a link between individuals (Lawrence, 1988). Furm tenure has been considered to have the best theoretical basis of all demographic variables (Pfeffer, 1983). Furthermore, Finkelstein and Hambrick (1990) showed that when using several measures of managerial tenure, i.e., tenure in position, in the top management team, in the industry and firm tenure, the latter variable appeared to be most highly correlated with the other tenure measures. They concluded that firm tenure served "as a central, parsimonious, indicator of the broad concept of tenure" (Finkelstein and Hambrick, 1990: 493). While age and tenure are often correlated, "there is enough variance not in common among the concepts to argue that they are conceptually distinct and should be kept so in both theoretical and empirical analysis" (Pfeffer, 1983: 305). Industry experience of workers has received limited attention in explaining company performance. Nonetheless, especially in service industries it is argued to be an important asset (Pennings et al, 1997).

Human capital theory and the upper echelon model have specific arguments on how the three personal characteristics affect organizational outcomes. Human capital theory, on the one hand, generally points to the benefits of the capital variables on the individual workers' productivity and strategic insights, so directly influencing firm performance. Upper echelon theorists, on the other hand, explain how demographic characteristics pertain to certain perspectives, values and information processing and how these perceptions and backgrounds affect strategic 
choices, which ultimately determine organizational performance: Although Hambrick and Mason (1984) suggest the existence of a direct relationship between upper echelon characteristics and firm performance, they place more emphasis on the indirect connection. The theoretical arguments of both views are discussed for each variable.

Age has, according to human capital theorists, a concave relationship with an individual's productivity (Bates, 1990; Preisendorfer and Voss, 1990). Corresponding to the relationship between age and earnings, productivity of young workers is low, but rises rapidly as their human capital increases and stabilizes as they "cease to invest in training" (Preisendorffer and Voss, 1990: 112). Middle-aged workers are believed to be most productive, whereas older workers may become less productive due to the depreciation of their skills (Preisendörfer and Voss, 1990) or a lessening of effort (Bates, 1990).

Upper echelon adherents suggest that top executives' age relates to firm performance through the mediation of its effect on strategic decision making (Hambrick and Mason, 1984). Since this theory argues that with age conservatism in strategic choices increases, a negative association between top managers" ages and company performance is expected, especially in complex and competitive environments in which risky decisions or changes of strategies may be necessary for success. Older individuals, and thus older top executives, tend to be more conservative, i.e., to have a lower propensity for risk taking and a greater commitment to the status quo than their younger counterparts (Hambrick and Mason, 1984). Several explanations for this behavior have been advanced. First, research has suggested that as people age, their flexibility diminishes and their resistance to change increases (Wiersema and Bantel, 1992). Cognitive abilities, such as learning competencies, reasoning and memory, diminish with age (Burke and Light, 1981). Older executives have a lower ability to grasp new ideas, learn new behavior (Chown, 1960) and integrate information in decision making (Taylor, 1975). Second, older managers may attach greater importance to financial and career security which, in order to maintain their favorable situation, induces avoidance of risky decisions and increases cominitment to the status quo (Carlsson and Karlsson, 1970). However, managerial age appears to be positively associated with a tendency to seek information, accurately evaluate information and the time needed to make a decision (Taylor, 1975)

Firm tenure is the most common operationalization of firm-specific human capital as proposed by human capital adherents. Human capital theory argues that firm tenure enhances productivity as the worker learns about the specific rules, norms and values prevailing in the firm (Pennings et al., 1997). Firm tenure within service firms is suggested to enhance firm performance, since the delivery of services becomes more reliable and reproducible as individuals stay longer with the same company (Pennings et al., 1997). Upper echelon theorists, on the other hand, do not uniformly advocate a specific linkage between tenure and firm performance. Finkelstein and Hambrick (1990), in an important study on the topic, argue that team tenure is 
positively related to persistence in strategies, conformity of strategies with industry averages and average industry performance, especially in complex and competitive emvironments (Finkelstein and Hambrick, 1990). The arguments behind this prediction, and on which upper echelon scholars agree, are based on a higher commitment to the status quo, risk aversity and gathering of less diverse information by long-tenured executives (Finkelstein and Hambrick, 1990). While the effect of age primarily concerns the decrease in cognitive resources, tenure has a larger impact on commitment to the status quo (Bantel and Jackson, 1989). An individual becomes more committed to the way an organization functions, the longer he/she works there and succeeds in climbing the hierarchy (Wanous, 1980). The more time a person spends in the same firm, the more (s)he gets committed to the status quo (Finkelstein and Hambrick, 1990) and to established policies and practices (Katz, 1982). In general, commitment to the status quo increases aversity for risk taking. Long-tenured managers are risk averse as they have far more to lose than to gain from a change in the current situation (Coffee, 1988; Finkelstein and Hambrick, 1990). Senior executives may have worked for years to reach their top positions, and they are, generally, endowed with more firm-specific than general human capital and have well-established social lives (Vancil, 1987). Long tenure may make managers overconfident and complacent, resulting in rigidity and resistance to reorientation (Miller, 1991). Finally, long tenure reduces information processing (Finkelstein and Hambrick, 1990) because, over time, managers develop a standard way of processing information and responding to environmental stimuli. Instead of using new information, they tend to rely more and more on past experience (Katz, 1982).

Industry-experience refers to tenure in the industry in which the individual is currently employed It may be operationalized as industry tenure and as work experience in the industry previous to the current employment. Both the human capital and upper echelon views agree on the benefits of this capital variable. According to human capital theory, industry experience, in terms of industry tenure, increases workers" professional skills (Pennings et al., 1997), improves their knowledge about profitable niches and enhances their productivity (Brüderl et al., 1992) Hambrick and Mason (1984), concentrating on prior employers, argue that career experiences mold an individual"s view on strategic opportunities and threats. Experiences in other organizations than the current one, another form of industry experience, are believed to be beneficial by enlarging the perspectives of executives. Especially when a firm is confronted with sudden difficulties, top managers' additional knowledge and experience gained by working in other firms may help them in finding solutions (Hambrick and Mason, 1984). In periods of stability, however, experience in other organizations is not believed to be particularly helpful. 


\subsection{From individuall to team effects}

This study analyzes the effect of the entire top management team composition on business performance. In explaining corporate outcomes by team make-up, both the average lovel of team members' features and the spread or distribution of characteristics among team members are important. With respect to the average level of team attributes, predictions are merely extensions of what is expected at the individual level. With regard to the diversity of demographic characteristics among team members, teams may be classified as homogeneous or heterogeneous, respectively, i.e., the spread of certain characteristics may either be small or large. Hambrick and Mason (1984) argue that demographic variables such as age, tenure and years of education refer to personal backgrounds, experiences, values and frames of reference that affect personal relations and group dynamics. Arguments about the benefits of either homogeneity or heterogeneity of team composition are, therefore, based on the group dynamm ics resulting from the cowarking between individuals with either similar or diverging values and perspectives.

The so-called facilitation perspective, arguing in favor of homogeneity, posits that similarity among team members, in terms of attribates such as values, attitudes and socio-economic status, enhances cohesion and social integration, which in turn facilitates communication frequency and effectiveness. For instance, a group of people of the same age cohort has probably experienced at about the same time several important events, such as marriage and having children, which increases mutual liking and communication (Hambrick and Mason, 1984; Boone et al., 1997). Similarly, people that have arrived at about the same time in a company are thought to undergo the same experiences, have ample opportunities for interaction (Gladstein Ancona and Caldwell, 1992) and develop similar perspectives (Wagner et al, 1984). This in turn induces them to be more attracted to each other than to members of other tenure cohorts. Advocates of the facilitation viewpoint bolieve that cohesion, integration and similar outlooks enhance team behavior and so team and firm performance (Boone et al., 1997). Important drawbacks of homogeneity among team members, however, are the low criticism vis a wis other team members and the decreasing responsiveness to environmental signals. In this respect, the danger of groupthink (Janis, 1972) has been pointed out (Hambrick and D'Aveni, 1992)

Authors preaching the benefits of heterogeneity among team members, on the other hand, indicate that diversity in group composition implies a larger variety of skills, knowledge areas and abilities. Diversity in age and tenure, for instance, are believed to increase the variety of perspectives conceming the strategic issues facing a firm. It is argued that, especially in complex environments, performance is enhanced by a wide range of viewpoints and critical attitudes of individual members (Boone et al., 1997). Filley et al. (1976) conclude that while novel and nonroutine problems are best handled by heterogeneous groups, routine problems are best 
solved by homogeneous teams. In this line, Hambrick and Mason (1984) propose that homogeneous teams will acheve better financial results in stable environments, whereas heterogeneous groups obtain higher profitability in turbulent environments. Important drawbacks of heterogeneity are that it hinders communication, reduces cohesion and interferes with team coordinaton (Pfeffer and $O^{\prime}$ Reilly, 1987). If not managed correctly, this may in turn slow down decision processes and increase the occurrence of conflicts, turnover and power struggles (Pfeffer, 1983; Wagner et al:, 1984; Gladstein Ancona and Caldwell, 1992), which all harm company performance.

\subsection{Prior research results}

A substantial number of studies has examined the effect of top team make-up on organizational outcomes, both strategies and performance. This section presents an overview and critical evaluation of the empirical research results with respect to the demographic variables included in the study, i.e., age, organizational tenure and industry experience. Only studies which relate the variables directly to firm performance are reviewed. This criterion led to the exclusion of studies linking the attributes to, e.g., strategic decisions (see, e.g., Miller and Toulouse, 1986; Bantel and Jackson, 1989, Wiersema and Bantel, 1992) and affective consequences such as absenteeism and turnover (see, e.g., Cummings et al., 1993). Although these consequences of team make-up may have an impact on firm performance in the long run, they are considered to be indirect in nature and, therefore, of less relevance to the topic addressed in this chapter. The overview is not meant to be complete, but to include at least the most important studies on the subject. Separately for each personal characteristic, Table 5.1 summarizes studies involving both individual leader and top management team effects. In the case of teams, both average level and diversity effects are reviewed. The impact of individual leaders' human capital is reviewed here as well, since hypotheses as to the average level of human capital of a group of individuals are extensions of what is predicted and found at the individual level.

\subsubsection{Swmmory of research findings}

\subsubsection{Age}

Average age and age dispersion in top management teams have been often linked to the occurrence of turnover and affective consequences. However, only few studies have examined the direct impact of (average) age on financial performance and survival chances (see Table 5.1 and the overview by Milliken and Martins, 1996). Heterogeneity has not been related to survival chances yet, and has been rarely linked directly to financial performance indicators. Table 5.1 shows that the results of the empirical studies on the effect of individual age and top teams" average age on company performance are somewhat inconsistent. 
Table 5.1: Summary of prior empirical swiles

\begin{tabular}{|c|c|c|c|c|}
\hline AUTHORS & SAMPLE & $\begin{array}{l}\text { INDEPENDENT } \\
\text { VARLABLE }\end{array}$ & $\begin{array}{l}\text { DEPENDENTI } \\
\text { VARLABLE }\end{array}$ & OUTCOMES \\
\hline \multicolumn{5}{|l|}{ Age individ ainll leaders } \\
\hline Batus $(1990)$ & $\begin{array}{l}7743 \text { self-employed } \\
\text { White males, Us }\end{array}$ & $\begin{array}{l}\text { Individual owner's } \\
\text { age }\end{array}$ & Sturvival & Inverted U-sinape \\
\hline $\begin{array}{l}\text { Prelisendourler \&e Woss } \\
\text { (1990) }\end{array}$ & $\begin{array}{l}78441 \text { founders of } \\
\text { new estabisimments in } \\
\text { West Gernary. }\end{array}$ & Founder"s age & Survival & Inwerted U*shape \\
\hline $\begin{array}{l}\text { Van Witteloostuigh ed } \\
\text { al. (1996) }\end{array}$ & $\begin{array}{l}\text { Chitef edtors of } \\
\text { matched pairs of } 11 \\
\text { fuiling and } 11 \text { survive } \\
\text { ing Duteh newspapers }\end{array}$ & Chief editor's age & Survival & Negative regationsiala \\
\hline \multicolumn{5}{|c|}{ Average age man agament teams } \\
\hline $\begin{array}{l}\text { Van Wittelowstuijn et } \\
\text { al }(1996)\end{array}$ & $\begin{array}{l}\text { TMIs of matched } \\
\text { pairs of } 11 \text { fasling and } \\
11 \text { surviving Dutch } \\
\text { newspapers }\end{array}$ & Areage age & Suryival & NS \\
\hline $\begin{array}{l}\text { Norbirn and Birley } \\
(1988)\end{array}$ & $\begin{array}{l}\text { Top management } \\
\text { teums of } 150 \\
\text { large companies in } \\
\text { fowe industries }\end{array}$ & Average age & $\begin{array}{l}\text { Sales growh } \\
\text { Employment growtin } \\
\text { Productivity (sales per } \\
\text { emlployee) }\end{array}$ & 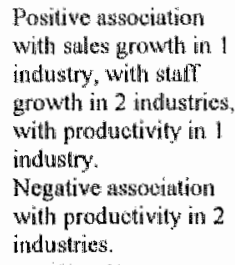 \\
\hline \multicolumn{5}{|c|}{ Heterogeneity of age management teams } \\
\hline Murray (1989) & $\begin{array}{l}\text { Top monagement } \\
\text { teams of } 84 \text { fortune } \\
500 \text { food and oil oom- } \\
\text { pantes, } 1967-1981\end{array}$ & 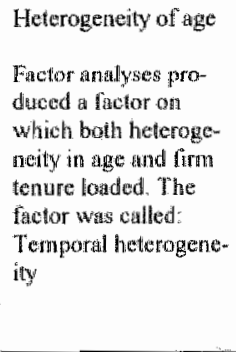 & 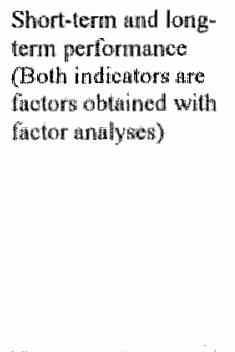 & 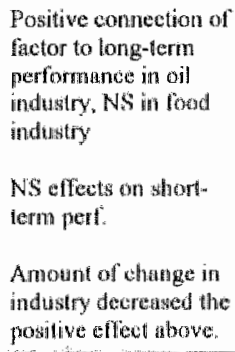 \\
\hline \multicolumn{5}{|c|}{ Finm tenure undivid vall lesaders } \\
\hline $\begin{array}{l}\text { Brone R Van } \\
\text { Witteloostunn (1996) }\end{array}$ & $\begin{array}{l}64 \text { CEOs of Nemish } \\
\text { furniture forms }\end{array}$ & CEO's lirm tenure & Protutability & $\mathbb{N}$ \\
\hline Whachun $(993)$ & $\begin{array}{l}35 \mathrm{CEO} \text { or advertis- } \\
\text { ing agencies thead- } \\
\text { quartered an the US. } \\
\text { UK and France) }\end{array}$ & CEO's liren tenure & $\begin{array}{l}\text { Sulvival } \\
\text { Combined meatsure of } \\
\text { profolabiluy and } \\
\text { motriket shares }\end{array}$ & $\mathrm{N} B$ \\
\hline
\end{tabular}




\begin{tabular}{|c|c|c|c|c|}
\hline AUTHOHS & SAMPLE & $\begin{array}{l}\text { WOLPENDENT } \\
\text { WARLABCE }\end{array}$ & $\begin{array}{l}\text { DEPENDENT } \\
\text { WAPLALLE }\end{array}$ & OUTCOMES \\
\hline \multicolumn{5}{|c|}{ A varage firm heature ins naggement teans } \\
\hline $\begin{array}{l}\text { Hambriok and } \\
\text { fy A wen }(1992)\end{array}$ & 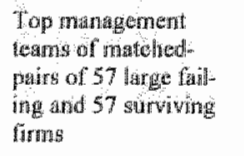 & Average firm tenure & Sarwikal & Posstive association \\
\hline $\begin{array}{l}\text { Wortbin and Birley } \\
\text { (1088) }\end{array}$ & $\begin{array}{l}\text { Jop managenent } \\
\text { deams of } 150 \text { lange } \\
\text { compranes an five in- } \\
\text { dustres }\end{array}$ & Average firm tenure & $\begin{array}{l}\text { Salles growth } \\
\text { Employment glowth } \\
\text { Productinvity (soles } \\
\text { per employee) }\end{array}$ & 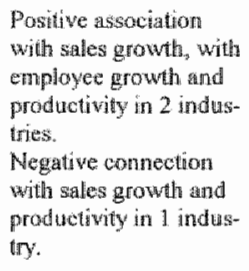 \\
\hline $\begin{array}{l}\text { Finkelstein } \\
\text { Hambrick }(1990)\end{array}$ & $\begin{array}{l}100 \text { firms in } 3 \text { ind us } \\
\text { tries varying in level } \\
\text { of discretion of } \\
\text { environment }\end{array}$ & Average firm tenurie & 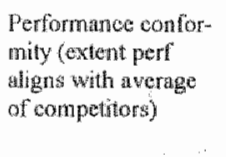 & $\begin{array}{l}\text { Positive rotatonship } \\
\text { The association was } \\
\text { strongest in the industry } \\
\text { whth the highest discre } \\
\text { tion }\end{array}$ \\
\hline \multicolumn{5}{|c|}{ Hetarogen eity of firm tantre managementert to ams } \\
\hline $\begin{array}{l}\text { Hambrick and } \\
D^{*} \text { Aveni (1992) }\end{array}$ & $\begin{array}{l}\text { Top management } \\
\text { teans of matohed } \\
\text { pairs of } 57 \text { large laill- } \\
\text { ing and } 57 \text { sorviving } \\
\text { firms }\end{array}$ & $\begin{array}{l}\text { Heterogentity of fintr } \\
\text { lentre }\end{array}$ & Survival & NS \\
\hline $\begin{array}{l}\text { Gildstein Ancont and } \\
\text { Catuwoll }(1902)\end{array}$ & $\begin{array}{l}\text { 45 new product toams } \\
\text { in shigh leotinology } \\
\text { lirms }\end{array}$ & $\begin{array}{l}\text { Heterogeneity of firm } \\
\text { letente }\end{array}$ & 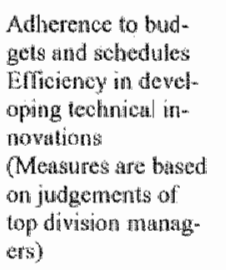 & 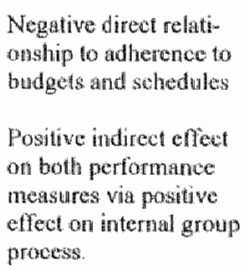 \\
\hline Murny $(1989)$ & 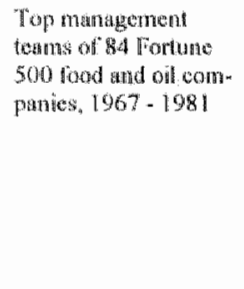 & 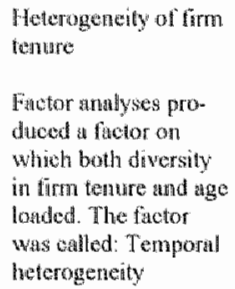 & 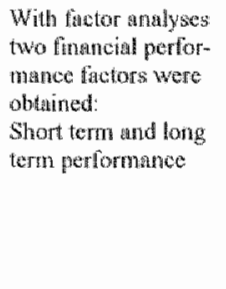 & 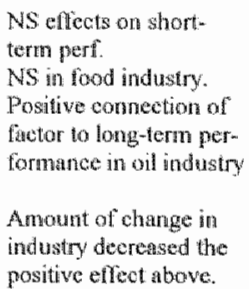 \\
\hline
\end{tabular}




\begin{tabular}{|c|c|c|c|c|}
\hline AUTHORS & SAMPLE & $\begin{array}{l}\text { INDEPENDENT } \\
\text { VARLABLE }\end{array}$ & $\begin{array}{l}\text { DEPIDNDENT } \\
\text { VARIARLE }\end{array}$ & OUTCONES \\
\hline \multirow[t]{2}{*}{ Smith ef sl. (1994) } & $\begin{array}{l}53 \text { high-tachnology } \\
\text { frrms }\end{array}$ & $\begin{array}{l}\text { Meterogeneify of firm } \\
\text { temure and industry } \\
\text { tenute }\end{array}$ & $\begin{array}{l}\text { Return on investment } \\
\text { (ROD) } \\
\text { Growth ins sales }\end{array}$ & 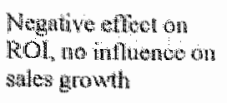 \\
\hline & & 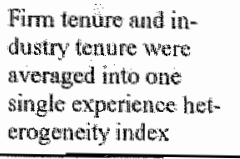 & & 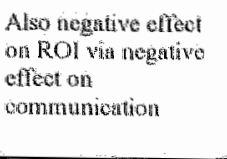 \\
\hline \multicolumn{5}{|c|}{ Industry experience individual leaders } \\
\hline Bribderl et al (1992) & $\begin{array}{l}1,849 \text { business } \\
\text { founders in Gemany. } \\
\text { Heterogenerons sum- } \\
\text { ple. }\end{array}$ & $\begin{array}{l}\text { Founder" ind watry } \\
\text { experience (dumny) }\end{array}$ & Survivut & Positive redalionship \\
\hline $\begin{array}{l}\text { Boone and Van } \\
\text { Wutheloostun }(1996)\end{array}$ & $\begin{array}{l}\text { CEO of } 64 \text { Flemish } \\
\text { furniture firms }\end{array}$ & $\begin{array}{l}\text { Number of former } \\
\text { employers }\end{array}$ & Proflebbillity & NS \\
\hline \multicolumn{5}{|c|}{ Inderstry experience managenent tearns } \\
\hline $\begin{array}{l}\text { Boone \& Vun } \\
\text { Witheloostujin (1996) }\end{array}$ & $\begin{array}{l}\text { Personmel at founding } \\
\text { of } 78 \text { eutrants in } \\
\text { Dutel audit industry } \\
\text { between } 1970-1975\end{array}$ & $\begin{array}{l}\text { of of personnel at } \\
\text { lounding with prion } \\
\text { andustry experience }\end{array}$ & $\begin{array}{l}\text { Surkiwal (rersug exit } \\
\text { by merger and acqui- } \\
\text { stion or disparaj }\end{array}$ & 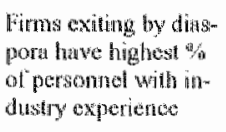 \\
\hline $\begin{array}{l}\text { Ponninges, Lee and } \\
\text { Vann Witcloostuijn } \\
(1995)\end{array}$ & $\begin{array}{l}\text { Partiners of the entire } \\
\text { population of Duteh } \\
\text { audit limms, } 1880 \text {. } \\
1990\end{array}$ & $\begin{array}{l}\text { Average number of } \\
\text { years in indusiry of } \\
\text { panthers }\end{array}$ & Miortanlity & Negetive relationship \\
\hline \multicolumn{5}{|c|}{ Heterogeneity industry experience managernent teams } \\
\hline Smith ef in $(1994)$ & $\begin{array}{l}5.3 \text { high-teehnotogy } \\
\text { firms }\end{array}$ & 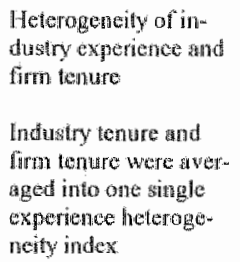 & $\begin{array}{l}\text { Returt on invertmont } \\
\text { ROD } \\
\text { Molowh an sollos }\end{array}$ & 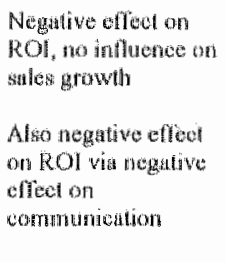 \\
\hline
\end{tabular}

No clear-cut conclusion can be derived from the findings and, therefore, neither the existence of a concave association nor a negative connection between (average) age and firm performance, as proposed by human capital and upper echelon theorists, respectively, seems to be consistently supported. While heterogeneity in age has not been investigated in relation to survival chances, the only reviewed study involving financial performance tends to point to the absence of a significant effect. 
The studies summarized in Table 5.1 are presented briefly, starting with the impact of (averge) age on survial chances and financial performance, and followed by the effect of heterogeneity in age on financial company performance. Examming the influence of individual founders' age on their firms" survival chances among a large sample of newly founded businesses in West Germany between 1980 and 1984, Preisendörfer and Voss (1990) report that companes of middle-aged founders showed the highest survival chances, whereas firms headed by the youngest and oldest founders had the llwest probability of survival. Bates (1990) reports a similar result among a sample of over 7,000 self-employed American males, studied between 1976 and 1982 . Business owners of 55 years of age and older were most likely to see their company fail, while fim owners in the age of 45 - 54 were most likely to remain in business. An examination of the individual age effect on firms" survival chances within a narrow sample produced a negative association. A matched-pair analysis of failing and surviving Dutch newspaper firms revealed that the chief editors of the surviving companies were significantly younger compared to the chief editors of their failing counterparts (Van Witteloostuijn et al., 1997). Turning to the team level, within the same sample, no significant differences were found between the average age of the entire top management teams of the failling and surviving newspaper firms (Van Witteloostuifn et al., 1997).

Financial firm performance has been related to the average age of entire top management teams by Norburn and Birley (1988). They examined the effects on three performance measures within five different industries. Each of the financial performance measures produced significant results in one or two markets only. Norburn and Birley (1988) report a significant. positive association between the average age of top management team members and sales growth within one industry, and within two industries when employee growth was concerned. With respect to productivity two industries generated a negative connection, while one industry displayed a positive relation (Norburn and Birley, 1988).

The impact of age heterogeneity on financial performance has been examined by Murray (1989). However, he executed a factor analysis on the independent variables. Not surprisingly, spread in age loaded on a factor with variance in firm tenure. The factor appeared to be unrelated to short-term performance in both industries under study, but positively connected to long-term performance in one industry.

\section{Firm temure}

Table 5.1 shows that the empirical studies investigating the effect of (average) firm tenure on business performance have produced contradicting results ${ }_{\text {, }}$ too. Neither a positive relationship, as proposed by human capital theory, nor a negative connection seems to be unambiguously supported. The outcomes with respect to spread in tenure are rather contradictory, too, but tend to favor a negative impact. The findings of the studies in Table 5.1 are, again, described 
brietly, subsequently regarding (average) firn tenure and heterogeneity of team tenure:

Nachum (1993) conducted a study among 35 advertising agencies and observed no effect of the CEOs' firm tenures on survival chances or financial performance. Investigating teams of top managers, Hambrick and $D^{\prime}$ Aveni (1992) report a significant positive association with survival chances. In a matched-pair analysis of failing and surviving firms, the top teams of failing firms had significantly shorter average firm tenures than the top executives of their surviving counterparts. Financial performance of firms has been related to both organizational tenure of individual leaders as well as to average team tenure. With respect to the individual level, among a homogeneous sample of 64 Flemish furniture firms Boone and Van Witteloostuijn (1996) found firm tenure to be unrelated to financial performance. Turning to the team level, Norbirn and Birley (1988) examined five industries and observed significant outcomes within two markets only. A positive linkage with sales growth and productivity emerged in one industry and with staff growth in the other industry. However, in this latter industry, a negative connection was obtained with sales growth and productivity. Finkelstein and Hambrick (1990) report a positive linkage between average tenure and performance conformity, i.e, the extent to which performance aligns with industry averages. In accordance with their predictions, the effect appeared to be stronger in the industry characterized by the highest discretion.

With respect to top teams' diversity in firm tenure, empirical studies generate no relationship with survival chances whilst mixed results emerge when the linkage to financial performance is concerned. In a matched-pair analysis of failing and surviving large firms by Hambrick

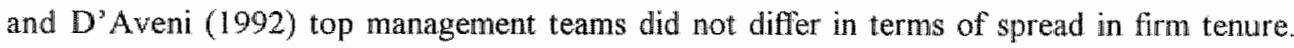
Financial performance does seem to be influenced by spread in team members organizational tenure. A negative association is reported by Smith et al. (1994) among a sef of 53 hightechnology furms and by Gladstein Ancona and Caldwell (1992) among 45 product teams of five high-technology firms. However, in the study by Smith et al. the diversity in terure was averaged with spread in industry experience into a single experience heterogeneity index. $A$ positive relationship is observed by Murray (1989) among large oil companies. However, no such relationship existed for food companies. An association with short-term performance was absent within both industries. Murray conducted a factor analysis on the independent variables which produced a factor on which the temure variable correlated with spread in age. It is this factor that was positively linked to long-term performance and unrelated to short-term outcomes.

\section{Industry experience}

The effect of industry experience on survival chances has received more attention in empirical studies compared to the impact on financial outcomes. Results generally support the expected 
positive association. At the individual level, Briderl at (1992) report that prior industry expertence of German company founders enhance new established firms' survival chances Turning to the effect of team characteristics on business survival, Pennings et al (1997) observe, among a homogeneous smple of Dutch audit firms, that average industry tenure of partners increases survial chances. However, among a subsample of 78 entrants of the same Dutch audit firm population, the percentage of permonnel at founding possessing prior industry experience proved to be highest for audit firms exiting by diaspora, as opposed to those firms continuing in their current form or exiting by merger or acquisition (Boone \& Van Witteloostuin, 1996)

\section{5 .2 Enathation of research findings}

The reviewed empitical studies examining the effects of average and spread in age and firm tenure on firm performance generated inconsistent outcomes. The diversity in results is probably caused by the fact that the studies differ with respect to their designs. First, the studies include different dependent wariables (survival chances, various financial performance measures such as sales growth, profitability and productivity, to name but a few), each of which may be affected by the team characteristics in a different way. Second, either heterogeneous samples of firms were used or studies were carried out in particular industries, implying that industry contingencies may account for variation in results. Third, either linear or non-linear relationships were tested. That is, the possible existence of a non-linear association was not analyzed in all studies. And finally, the samples included either individual leaders (that differed in status: founders, owners or neither of these) or teams of managers. For instance, with respect to survival chances, two studies report a concave association with age (Bates, 1990; Preisendorfer and Voss, 1990), in one study a negative relationship is obserwed (Van Witteloostuijn at al. 1997) and another analysis produces no connection at all (Van Witteloostuijn, et al. 1997). However, while the first two examinations involved large heterogeneous samples of business owners, the latter two concerned a single industry with top managers who did not necessarily own shares in the company. Furthermore, the latter two examinations did not test for nonlinearities. And finally, the last investigation involves the team of managers, whereas the other three pertain to individual leaders. The direct effect of team composition on company performance depends, apparently, on these design aspects.

Hambrick and Mason (1984) had foreseen mixed findings between industries and suggested to control for industry, either through the use of single industry samples or matched-pair designs. What seems to be needed is a contingency framework, indicating when what is effective. Hambrick and Mason (1984) propose, for instance, to distinguish between stable and dynamic environments, or as Finkelstein and Hambrick (1990) have called it, between high and low discretion environments. The impact of managers' characteristics on firm outcomes is 
suggested to be larger in industries in which the need for action is largest, that is, in complex or high-discretion environments (Finkelstein and Hambrick, 1990), Jn industries in which there is product differentiability, demand instability, low capital intensity, a competitive market structure, market growth and freedom from government regulation, the level of managerial discretion may be relatively large (Finkelstein and Hambrick, 1990). Furthermore, organizational characteristics may also affect managerial discretion. Organizational inertia, which occupies an important place in theories of organizational ecology (Hannan and Freeman ${ }^{1984}$ ), inhibits the possibility of managerial change (Finkelstein and Hambrick, 1990). In large and inert organizations, managerial discretion is, generally, limited. A study conducted in three industries varying in their level of discretion showed that the effect of top management team demographics on firm performance was indeed most pronounced in the industry characterized by the highest discretion environment and organizational discretion (Finkelstein and Hambrick, 1990). These results indicate that a classification of industries in terms of dynamism and average firm size is an appropriate way of modeling the differences in the (obtained) effects of top managers' characteristics on firm performance.

Table 5.1 shows that previous research has focused exchsively on the independent effects of average team characteristics and diversity in team attributes on company performance. However, there is good ground to assume that both team measures interact in their impact on performance as well. The reason for this is that the same average level of a characteristic may hide different team compositions in terms of diversity, and vice versa. For instance, suppose two teams with three managers. The first team consists of managers in the age of 35,40 and 45 , whereas the second team has executives of 20,40 and 60 years old. While both teams have exactly the same average age, the former team includes three members of the same age cohort. whilst the latter team combines managers of three generations. If the mean is intended to measure the accumulation of certain skills witlin a team, one would expect the average team characteristics to interact with measures of team diversity (e.g., the standard deviation). That is, the impact of the average level of a specific team attribute should be stronger in homogeneous teams as opposed to heterogeneous teams. At the same time, when a team lacks certain required skills, as measured by the mean, diversity in characteristics is more likely to be beneficial. Spread may imply that the competencies associated with the personal characteristic are embodied in at least one of the team members. An example may clarify this reasoning. Con sider that teams of young managers obtain better organizational results compared to teams with older executives. In that case, the positive effect of a low average age will be stronger when the team is homogeneous in terms of this attribute (i.e., the required skills associated with young age are present in all members). However, when the team consists of, on average older managers, diversity in age will contribute to firm performance (at least one executive would be relatively young and possess the effective skills). In order to explore the validity of 
this argument, interaction effects between average and diversity of team characteristics are included in the present study.

\section{Additional variable}

This study is designed to test the effect of demographic characteristics of top managers on advertising agency performance. While focusing on the impact of managers on firm outcomes, their contractual relationship is of key importance, as predicted by agency theory. An additional variable pertaning to this important feature, i.e., firm ownership, is, therefore, included in the study as well. Principal-agent theory argues that individuals who own shares in the company are more motivated and have more incentives to behave in the best interests of the firm compared to managers that do not own company shares (Boone and Van Witteloostuijn, 1996). In this line of reasoning, owners of professional service industries, where human capital constitutes an important source of competitive advantage (Maister, 1993), have more incentives to use their human capital to enhance firm performance than employees (Pennings et all, 1997)

Empirical studies provide evidence for a positive effect of manager owners on company performance. For example, Audretsch and Mahmood (1995) observe that independent entrants have higher survival rates than branch and subsidiary newcomers, and Boone and Van Witteloostuijn (1996) repont that surviving Dutch audit firm entrants were headed by the highest proportion of manager owners. These same authors (1996) found, among a sample of 64 Flemish furniture firms, that higher financial performance was achieved by companies directed by (family of) the founder. Finally, Oswald and Jahera (1991) reported that firms with managers owning shares of the company obtained significantly higher performances.

\subsection{Top managers" demographics in the Dutch advertising industry}

Before turning to the hypotheses, it is appropriate to justify the choice of the industry. First of all, a substantial number of the reviewed studies hardly hypothesize on the impact that top team demographics may have in the particular industries they examine. However, as pointed out above, the direction and strength of the effects depend on industry contingencies (see, e.g., Norbum and Birley, 1988). Hambrick and Mason (1984) therefore propose to use single industry samples or matched-pair designs. Finkelstein and Hambrick (1990), suggest to take account of the amount of industrial and organizational discretion. This study is conducted in a single industry and hypotheses are formulated, separately for each variable, based on theory, prior research findings and specifics of the Dutch advertising industry

The adverting industry is believed to be an appropriate setting to study the effects at hand because (i) it is a dynamic industry (high environmental discretion), (ii) being occupied by small firms (high organizational discretion), (iii) for whom success depends largely on the attraction 
of new clients, a process in which personal relationships and advertisers" perceptions of agencies service quality play an important role. Each of these points receives attention below. The Dutch advertising industry may be typified as a competitive industry since industry s features are product differentiation, low entry barriers and, especially in the preceding ten years, tough competition. Furthermore, the advertising industry is a professional service industry in which human capital, embodied in professionals, is believed to constitute an important source of competitive advantage (Maister, 1993). Top execulives' demographic characteristics are, furthernore, likely to affect advertising agency performance as Dutch agencies are rather small firms in which the impact of "human factors" is believed to be stronger than in large orginizations (Boone and Van Witteloostuijn, 1996). "The positioning and (strategic) choices of an agency are primarily the result of the personalities of the individuals in charge. What they find important, their interests, talents and characters determine the face of the agency ${ }^{\text {nt } 2}$

In discussing the effect of personal characteristics on firm performance, as proposed by human capital and upper echelon theories (see Section 5.3), the emphasis in previous research was on the effectiveness of the individual in terms of productivity and choosing the right strategies. However, especially in service industries where the attraction and retention of clients are key factors to success, additional attention should be paid to the impact of personal characteristics on agency perceptions by advertisers. Advertising is a service, implying that agencies work on order, not on stock. The perceptions of clients are crucial to agencies because they select the agency at which they place their account. The importance of the acquisition of new customers is illustrated by the fact that especially large accounts switch rarely from one agency to another (Michell, 1988); some accounts may remain with the same agency for over 15 years (Commission of EC industries, 1994). Obtaining new accounts is a difficult job (Commission of EC industries, 1994) in which personal characteristics are believed to play an important role. A number of studies has examined the criteria that advertisers apply when selecting an advertising agency (see, e.g., Cagley and Roberts, 1984; Cagley, 1986; Bochove, 1994; Nachum, 1993). Several studies that included the importance of the quality of the personall relationship (Verbeke, 1989, $\mathrm{CSO}, 1994$ ), found this selection criterion to play a role. For instance, a large scale study entailing the satisfaction of advertisers vis a vis their current agencies, conducted in the Dutch industry, revealed that while Dutch advertisers found efficiency of working the most essential satisfaction criterion, a good personal relation occupied a sixth position (in total 12 criteria were rated) (CSO, 1994). Personal characteristics surely play a role in the decision process, since the final choice is always preceded by a personal confrontation between service providers and clients. Moreover, since the agency - client.

\footnotetext{
${ }^{2}$ Personal communication to the atuther (1994) by Protessor Oiep Franzen, one of we founders of FHWBBDO, the mogit successful agency in the Netherlands
} 
relationship is characterized by frequent and preferably long-lasting personal contact, mutual liking between the two parties seems to be a prerequisite for the success of the relationship. Age may play a role in this process since, as argued above, it refers to certain perspectives and values which influence attraction and colesion.

Perceptions of advertisers not only pertain to the importance of personal relationships, but also to service quality. As services are largely "people-work", one can expect differences in service performance between individuals as well as of an individual over time (Enderwick, 1992). Most services are, therefore, characterized by variation in quality, which makes it difficult to control current quality and to assure future quality. Since the quality of services is often difficult to assess, personal attributes such as industry and firm experience may serve as alternative indices of competence (Pennings et al., 1997). Prolonged firm tenure may be interpreted as an indicator of reliability in the provision of services (Pennings et al., 1997). When age is concerned, "middle age" is argued to have the best quality image: young adpeople still have to prove that there is consistency in the quality of their services whilst older executives must demonstrate that they can compete with the new generation and keep up with modern "advertising styles". Furthermore, since "name" and "reputation" of individuals are often key characteristics for attracting clients (Commission of EC industries, 1994), work experience at other agencies, especially at a top agency, is considered by advertisers as an indicator of high skills and high-quality work. Firm growth is best achieved by obtaining larger accounts than those currently handled, but these are difficult to attract due to a perceived lack of experience with large clients. Former work experience at a large agency may, then, help by indicating to the advertiser that the individual is able to treat a large account properly. Additionally, since personal contacts between admen and advertisers are an important key to the success and duration of the relationship (Cagley, 1986; Commission of EC industries, 1994), prior experience may secure future clients. It occurs quit often that when an individual leaves his/her present agency to move to another agency or to create a new one, some clients accompany the person to the new agency ${ }^{3}$.

\subsection{Hypotheses on top executives' demographics and firm performance}

\subsubsection{Team variables}

The above argument suggests that the age of top executives influences agency performance by the choice of strategies and positioning decisions, and additionally by the acquisition of new clients. As with all characteristics, predictions about the team's average age and firm perfor-

\footnotetext{
${ }^{3}$ In geneal only wear later, since contracts between agenoics and their employees try to prevent that this happens all too

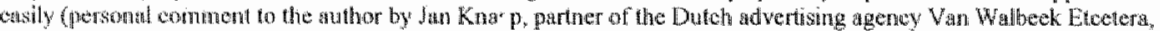
1994 .
} 
mance linkage are elaborations of what was expected and found in former research at the individual level. If individuals are most productive and perceived as most competent when they are of "middle-age", in the advertising industry, ceteris paribus, a concave association is expected between the average age of top executives and agency performance.

H1 There is a concave relationship between the average age of top executives and advertising agency performance.

While heterogeneity in the age of top managers is believed to enhance creativity in strategic decision making, it has, in prior research, produced insignificant associations with strategic choices and prowided weak support for a direct positive impact on financial performance. However, since the advertising industry was argued to be a complex environment in which strategic changes may be important, heterogeneous top management teams are expected to perform best in this industry. Furthermore, as age is an important factor influencing mutual liking between individuals, a higher diversity in top management teams in terms of age assures a higher chance of similarity in age between the advertiser and an agency executive, which in turn increases the likelihood of account acquisition. In the present sample, a positive connection is expected between spread in age of top management team members and agency performance, all other things equal.

$\mathrm{H} 2$

Diversity in the age of top management team members is positively associated with advertising agency performance.

It is argued above that average and spread in team characteristics may interact in their effect on firm performance. In teams in which the average level of a certain characteristic implies the availability of skills, homogeneity may enlance performance. However, if the average team attribute signifies a lack of important competencies, diversity among team members should increase firm performance. Applied to the impact of top management team imembers' age composition on company performance, the following interaction effect is predicted. If Hypothesis 1 is confirmed and teams consisting of, on average, middle-aged managers are most productive, then, ceteris paribus, a homogemeous team of middle-aged executives would produce better agency outcomes than a team with the same average but larger spread in age. Conversely, teams with, on average, either young or old members are supposed to lack the required skills as measured by the team's average age, and diversity in members age is, therefore, believed to be most beneficial for firm performance. Naturally, if not a concave but a different effect of average age on agency performance is obtained, a similar argument holds. 
The effect of the average age of top managers on advertising agency performance is stronger within "age homogeneous" teams".

Prolonged firm tenure was suggested to enhance firm performance according to human capital theory, but to harm strategic change and so company performance in the upper echelon view. Empiricall research has reached inconclusive findings. However, a combination of the two predictions, i.e., a nonlinear relationship, may best typify the situation in the Dutch advertising industry. Short-tenured top teams have to demonstrate that they are capable of continually providing the same quality of services, but long-tenured management teams may become inert and aversive to strattegic changes, which may harm performance. Therefore, in the Dutch advertising industry, all other things equal, a concave relationship is expected between the average firm tenure of top management teams and organizational performance.

There is a concave association between average firm tenure of top executives and advertising agency performance.

Previous empirical studies have obtained contradictory results as to the effect of heterogeneity in organizational tenure among top managers on firm performance. However, since the advertising market is a competitive industry, following group literature, a variety of viewpoints and perceptions among top managers may produce the most appropriate solutions to the dilemmas agencies are facing. Therefore, spread in firm tenure among top executives is, ceteris paribus, expected to enlance performance among Dutch advertising agencies

H.5 Heterogeneity of firm tenure among top executives is positively related to advertising agency performance.

It was suggested previously that the effect of average team characteristics on agency performance may depend on the spread in the same attributes, and vice versa. Applying this reasoning to the impact of team members' firm tenure on agency performance, the following interaction effect is expected. If a concave relationship between average firm tenure and agency performance is observed (Hypothesis 4), then, ceteris paribus, homogeneity in terms of firm tenure is suggested to enhance firm performance when the average firm terure is "middlelong". However, diversity in firm tenure within teams is assumed to be beneficial when the average firm tenure is either short or long. Of course, a similar reasoning applies when a negative or positive rather than a concave connection between average firm tenure and perfor:-

\footnotetext{
* Note that Hypotheses 2 and 3 contradict cach other and can not be confirmed aimultaneously.
} 
mance is reported.

H6 The effect of average agency temure of top executives on advertising agency performance is stronger among "tenure homogeneous" top management teams".

Theory and results of previous empirical studies generally point to the benefits of industry experience. If work experience in the industry prior to current employment provides executives with larger professional skills and better insight into strategic opportunities and threats, and if it is perceived by advertisers as an indicator of increased knowledge and competence, advertising agencies headed by executives with prior agency experience should, all other things equal, perform best.

H7 The proportion of top executives with work experience in the advertising industry prior to current employment is positively related to advertising agency performance ${ }^{6}$.

It was previously argued that especially work experience at a top agency enhances a manager's skils and perceived service quality. Experience at a top atgency is, thus, suggested to have a positive relationship with agency performance, ceteris paribus.

H8 The proportion of top managers with previous work experience at a top agency is positively related to advertising agency performance.

Firm ownership by managers is theoretically argued and empirically found to enlance firm performance. Consistent with theory and outcomes of prior research, among Dutch advertising agencies, ceteris paribus, those headed by proportionally more owner-managers are expected to achieve better performance.

H9 The proportion of managers owning shares in the agency is positively related to advertising agency performance.

\subsubsection{Control variables}

A mumber of variables is included in the study as control variables since they may account for

\footnotetext{
${ }^{5}$ Mote that Hypotheses 5 and 6 contradiet each other and ean not be confirmed simultameously.

With regard to industry experience and partnership, hypotheses are derived with respect to averages only (i.e, proportions, see 1. Hypothesis 7, 8 and 9). Pilot analyses showed that the impact of measures of spread on performunce were strongly insignificant.
} 
the relationship between top management team composition and agency performance. These variables are firm size, fim age, ownership status, location and team size. Firm size has been demonstrated to be related to survival chances as well as to growth rates (see, e.g.; Dunne and Hughes, 1994 , Doms at, 1995). Among the present sample of advertising agencies size is, as expected, positively connected to productivity and survival chances, and negatively related to agency growth (see Chapters 3 and 4 ). Firm age has been found to be positively related to productivity and survival; chances, and negatively related to firm growth (see, e.g., Dunne, Roberts and Samuelson, $1989 \mathrm{a}$ and 1989b). Within the current sample of advertising agencies, contrary to prior findings; organizational age revealed to be negatively associated to productivity but; consistent with previous research, negatively associated with firm growth (Chapter 3 and 4). Furthermore, opposite to the expectation, firm age revealed to be unrelated to survival chances (see Chapter 3 and 4 ). Advertising agencies that are (partly) owned by multinational advertising agencies may have the advantage of being assured of several (international) clients that are obtained at the headquarter level. The acquisition of these clients is by no way influenced by the human capital of the Dutch top executives. However, Chapter 4 has failed to provide evidence for a significant connection between (partial) ownership by a large advertising firm and agency performance. The location of Dutch advertising agencies is an important: predictor of agency performance. Chapter 4 has shown that advertising agencies located in the so-called Randstad generate, on average, higher revenues and have a lower likelihood of failure, all other things equal, than agencies seated in other regions of the Netherlands. Empircal studies that have investigated the effect of team size on firm performance provide mixed results. While Eisenhardt and Schoonhoven (1990), for instance, report a positive relationship between firm growth and top management team size (absolute number of founders), Smith et al. (1994) observe an indirect negative effect of firm size on performance through the negative influence of team size on informal communication and social integration. Among the sample of Dutch advertising agencies a positive impact of team size on firm performance was already observed in Chapter 4

\subsection{Methods}

\section{8 .1 Sample and measurement}

The sample consists of 89 Dutch advertising agencies over the period 1984 - 1994. Many agencies were not in the sample for all eleven years, due to entry after 1984 , exit before 1994 or missing observations, yielding 384 observations?. The annual number of firms varies from 28

\footnotetext{
${ }^{\gamma}$ 'the original number was: 390 , but six obserwations from one agency were excluded fron the sample. In the particular years the agenoy was headed by ono extremely old and long-tenured indivdual, so constituing oufliers on age and firm terture, significanty unfuencing the outconnes of the sualyses described below.
} 
to 45 , with an average of 35 agencies per year. In order to obtain a sample of advertising firms with sufficient information on the top management team members, agencies were included in the study only when personal information was available of at least 75 percent of the top executives. The result of the application of this criterion is that, on average, of 98.43 percent of the agencies" board members each personal characteristic is available". With 384 observations of agencies and an average of 3 board members per firm, in total 1171 observations of managers and their characteristics are collected. The personal attributes of top executives were gathered from industry yearbooks in which several agency and individual board member characteristics are presented (Blauwe Bugamor", "Blauwe Burogidsen" "Blawwe Bureau Tribune' and 'Adformatie Bureaubijlagen')

The dependent variable is the performance of advertising agencies. Performance is operationalized in terms of firm income, firm growth and firm failure. Firm income is measured by the natural logarithm of the gross income of advertising agencies. Cross agency income is the difference between the sum of money invoiced to clients and the amounts paid to suppliers (on behalf of the clients). Gross income is measured in millions of Dutch guilders (constant 1994 prices). Firm growth is operationalized as gross income growth, which is a frequently used proxy in the advertising industry for agency performance. It is measured by $\Delta \ln ($ income). Failure means exit from the sample before 1994, referring to either bankruptcy, dissolution or insufficient data ${ }^{11}$. Firms exiting the data set due to a merger or acquisition are not treated as failures. These companies continue to exist, although in a new form. Furthermore, Chapters 2 and 3 have demonstrated that this category of exiters differs significantly from the other categories in terms of size and pre-exit performance: they are larger and perform relatively well in the years preceding the merger or acquisition.

The independent variables included in the study are operationalized as follows. Agency size is measured in terms of the natural logarithm of the number of employees. Team size refers to the natural logarithm of the number of executives in the top management team. Top executives" age is obtained by a subtraction of the current year minus the date of birth. Top managers" firm tenure is a subtraction of the current year minus the first year the individual was employed by its present agency. The cherage age and the average firm remure of top management teams are calculated with the mean of individual board members' ages and firm tenures. Spread of age and diversity of firm tenwe are captured with the standard deviation of the ages

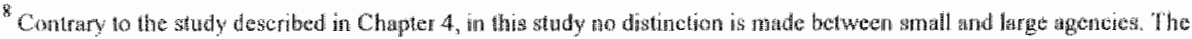
subsample used in this chapter is too smath to be disvided into two groups with a reasonabie size.

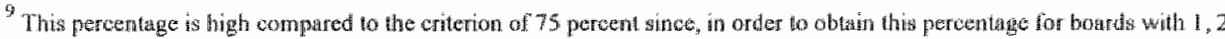

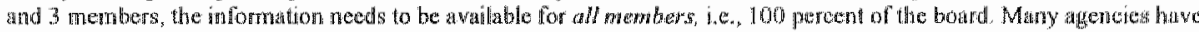
small boards.

Hee Chater 2 for precise explanations of these exit categories.
} 
and tenures of team members. In former studies, spread in the attributes of team members has generally been measured with the coefficient of variation (standard deviation divided by the mean) (Murray, 1989; Wiersema and Bantel, 1992). However, the standard deviation is considered to be a better indicator of team heterogeneity. Since the coefficient of variation is a measure of spread that is independent of the mean, it remains unchanged when the individual measures (eg, the separate ages of individuals making up a team) are multiplied by a certain number. The standard deviation, however, does increase through a multiplication of its individual values. This aspect is assumed to be important in studies involving spread in characteristics of team members where not the relative but the absolute differences between the members affect team functioning. As argued in the theoretical background section, absolute differences in, for instance, age refer to different sets of values and frames of references. While executives differing five years in age may be considered to be of the same generation, a discrepancy of ten years points to different generations. Teams consisting of members of different age cohorts are believed to have different behavioral properties, affecting team and firm performance, compared to teams constituted of individuals of roughly the same age cohort. The absolute differences should, therefore, be reflected in the measure of team heterogeneity, and the standard deviation is, thus, preferred to the coefficient of variation.

The team's prior indwstry experience is denoted with the percentage of members that was employed at another agency before arriving at the current firm. In the case of a merger, if an individual has, prior to the merger, worked only for one of the two firms imwolved in the merger, this is not counted as prior agency experience. Similarly, teams' top agency experience is denoted with the percentage of members with work experience at an agency belonging to the Dutch top-20 agencies before arriving at the current firm. Partmership of team members is indicated with the percentage of executives owning shares in the company. The latter three variables, prior industry experience, top agency experience and partnership, are divided by 10 for presentation purposes. The region in which an agency is located, is denoted with a dummy variable, 1 indicating the Randstad and 0 referring to all other regions in the Netherlands. The Randstad is the city triangle Amsterdam, Rotterdam, Utrecht, which is proxied by the three provinces North Holland, South Holland and Utrecht. Ownership status is measured with a dummy, I representing (partial) ownership by a large, multinational agency and 0 otherwise. Finally, firm age follows from extracting the founding year from the observation year.

\section{8 .2 Analyses}

The impact of top management team composition on financial performance is investigated using regression models on pooled cross-sectional and time-series data. Fixed-effects models are estimated including a dummy variable for each firm and year. Fixed-effects models estimate only within-firm variation over time and eliminate across-firm variation (Judge et al., 1982), so 
constituting a very conservative test of the hypotheses. The analyses are carried out on the set of firms whose information is available for at least two years.

In order to test the hypotheses with income and income growth as the dependent variables, Cobb-Douglas type functions, using fixed-effects estimators, are used to which measures of top management team composition have been added, e, the average and spread in age and firm temure, the proportion of top executives with prior industry experience, the proportion of top managers with top agency experience and the proportion of manager owners. The CobbDouglas function is used to measure the productivity of employees. The variables that directly concern labor are, therefore, measured in natural logarithms (staff size and board size)" .

To examine how the human capital of the firm's board affects the firm's probability of failure, logistic regressions are carried out ${ }^{12}$. Since the number of firms that exit the sample is very small, the regressions are estimated on the average values of the firms over the time period they are included in the sample (cross-sectional analyses using agency means). The analyses include a control variable for the number of years a firm is in the sample. The reason is that failing firms that are in the data set for a relatively large number of years may have had, contrary to agencies included in the sample for a short period, more years of prosperity during the time period under study, which may influence the relationship between team composition and failure chances.

In order to test the hypotheses, two sets of firms are distinguished. The first set includes all the firms in the sample, whereas the second set is a subsample consisting only of agencies with two or more board members. While the whole sample is used to assess the impact of "average and proportion variables", the spread and interaction effects are estimated within the subsample: spread in age and tenure of top executives can only be calculated when the board consists of at least two board members. Deciding to use only the subsample of firms with two or more board members to estimate the effects of all independent factors would lead to an. unnecessary loss of data. Section 5.9 .2 presents the outcomes of the effect of the "average trait and proportion variables" on performance using the entire sample. Section 5.9 .3 summarizes the impact of the spread and interaction variables on performance based on the subample of firms with two or more board members. More specifically, the results of the influence of team

\footnotetext{
1" OLS models have been carried out as well but likelihood ratio tests have indicated that fixed-chects models explain significantly more variances

"12 Hazard nodels would have been preferred, howewer, due to a lack of firm data ower time as a resull of right and left. censoring, it is of litile use to carry these andyses out, and, exploratiwely, logistic regression analyses are ekecuted,
} 
composition on financial performance are discussed in Sections 5.9 .2 .1 and 59.3 .1 . The outcomes of the impact of team make up on survival chances are presented in Section 5.9 .2 .2 and 5.92.

\subsection{Results}

\subsubsection{Somple descriptives}

The descriptives of the sample of Dutch advertising agencies are provided in Table 5.2. The entire sample consists of 384 observations and 77 separate agencies. The descriptives are calculated using the pooled cross-sectional and time-series data, i $e_{c}$, the observations ( $N=384$ ), except for exit, assessed at the firm level $(N=77)$. The advertising firms in the sample obtain an average annual income of 5.43 million Dutch 1994 Guilders, employ an average of 25 people with 3 board members. The smallest income and staff size observed in the sample are .33 million Guilders and 3 employees; the maximum income and staff size are almost 40 million Guilders and 149 people.

Table 5.2: Descriptives

\begin{tabular}{|c|c|c|c|c|}
\hline $\begin{array}{l}\text { Variables } \\
N=384\end{array}$ & Mean & Standwald deviation & Minimaum & Maximum \\
\hline $\begin{array}{l}\text { Antwome (in unilions of } \\
1994 \text { bFil. }\end{array}$ & 5.43 & 5.78 & .33 & $39.7 \%$ \\
\hline Euployecs (4) & 2483 & 23.67 & 3 & 149 \\
\hline Buard motubers (fisy) & 3.05 & 1.54 & 1 & li. \\
\hline Growth (incounte) & 789 & 49.32 & .63 .08 & 117.96 \\
\hline Binn fintlure & .15 & 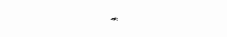 & " & . \\
\hline Finm age & 17.91 & 16.70 & $c^{n}$ & 84 \\
\hline Owoursthip & .390 & *. & - & $n$ \\
\hline Rutadntat: & .85 & - & . & - \\
\hline Mentin ange & 43.56 & 4,89 & 31 & 62 \\
\hline 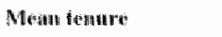 & 7.84 & 4.93 & 0 & 2.1 \\
\hline Sill atgot & 4.18 & 2.86 & 0 & 1838 \\
\hline Sill temued & 2.93 & 3,58 & 0 & 1485 \\
\hline 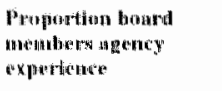 & 88.38 & 24.81 & 0 & 100 \\
\hline 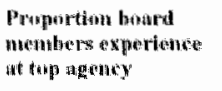 & 50.44 & 40.45 & 0 & $n \infty 0_{0}$ \\
\hline $\begin{array}{l}\text { phropention board } \\
\text { memenhers parther }\end{array}$ & 74.96 & 40.60 & 0 & 100 \\
\hline
\end{tabular}

' $N \cdots 7$

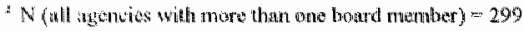


The average growth rate (in terms of percentual growth in income) of the agencies is 8 percent, with extremes of -63 and 118 percent, respectively. Thirteen firms, or fifteen percent, of the total of 77 agencies in the sample exit the sample before 1994 . Furthermore, 39 percent of the companies is (partly) owned by a larger (multinational) advertising firm and 85 percent of the agencies are located in the Randstad. The average age of the companies is 18 years, with the youngest being founded in the specific year it is observed in the sample and the oldest agency being 84 years of age

The average age within the agencies' top management teams is 43 years, with a minimum and maximum of 31 and 62 years, respectively. The average firm tenure of the boards is almost 8 years, with extremes of 0 and 21 years. A firm tenure of 0 means that the executives have started working for the agency during the year of the observation. There is greater dispersion in age than in firm tenure within the top management teams. While the average proportion of board members with prior work experience in the industry is about 89 percent, the mean proportion of board members having experience at a top agency is 50 percent. Finally, on average, 75 percent of top executives own shares in the company. For each of the latter three top management team characteristics minimum and maximum proportions of 0 and 100 percent are observed in the sample.

Table 5.3 presents the correlation matrix. While few correlations are high, many variables are significantly linked. For instance, unsurprisingly, the three size indicators, firm income, staff size and board size are positively and highly correlated. Furthermore, the performance measures income growth and exit appear to be unrelated. Consistent with the findings in Chapter 3, agencies that fail do not necessarily display low growth rates in the years preceding exit.

Consistent with Pfeffer's observation (1983), top management teams' mean age and mean firm tenure are positively related. However, the correlation is not so high that multicollinearity between the variables would hinder including them both in the analyses. The modest correlam tion points to the fact that in the advertising industry executives are rather mobile, that is, they switch relatively often from one agency to another.

Several other remarkable (sets of) correlations emerge. First, a negative connection exists between the board's average firm tenure and the proportion of members with prior experience at a top agency. This may imply that top experience increases agency mobility or that top executives with prior experience at top agencies become a board member relatively fast. Second, among agencies that are (partly) owned by a multinational advertising firm, a larger proportion of the board members has prior top agency experience, compared to advertising agencies that are exclusively owned by their executives. In the former agencies, board member's are more frequently "hired" for the firm and subsequently "chosen" to become member of the board than in the case of manager owned advertising agencies. 


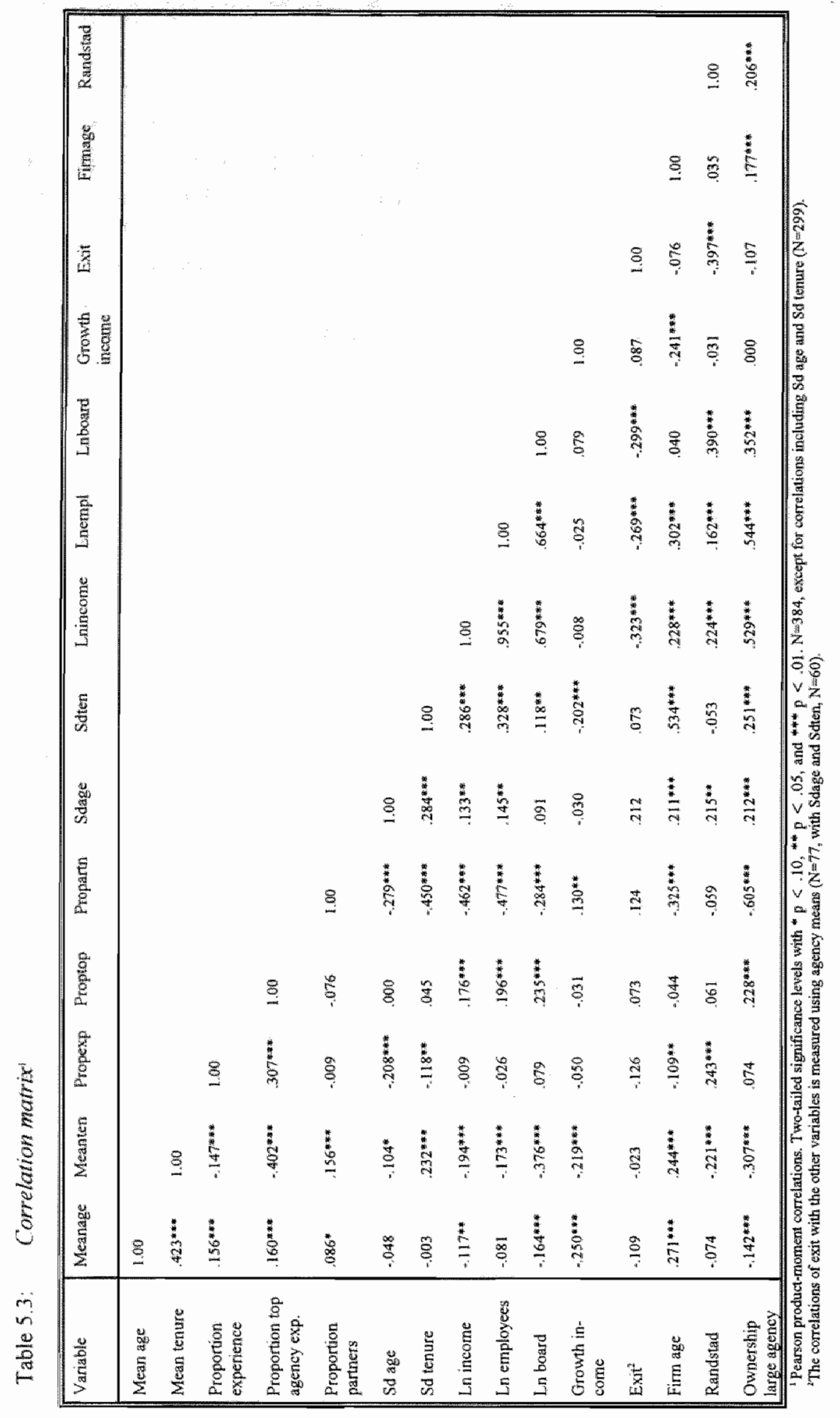


It is very likely that multinationals tend to take the best qualified people in their boards, which will generally be individuals with former top agency experience.

Third, the mean age and mean firm tenure of board members appears to be highest among the smaller and older agencies, agencies located outside the Randstad, and those owned by a large proportion of board members, being rarely owned by a multinational agency. The greatest dispersion among top managers" ages and firm tenures is observed among the larger and older agencies, by those owned by multinational advertising firms and agencies with a small proportion of manager owners. This observation is consistent with the fact that in the advertising industry, executives, especially those that do not own shares in an agency, change relatively often from one advertising firm to another.

\subsection{Average and "proporfional" team characteristics and agency performance}

This section presents the outcomes of the analyses testing the effects on agency performance of average age, average firm tenure, the proportion of executives with (top) agency experience and the proportion of partners within the teams (Hypothesis 1, 4, 7, 8 and 9). These analyses are carried out on the whole sample of advertising agencies. The results with respect to financial performance (income and income growth) are summarized in Table 5.4. The outcomes concerning the probability of failure are presented in Table 5.5 .

For each dependent variable separate regression equations are tested for three models. First, in model 1, only control variables are included in the analyses. In Model 2, the impact of control variables, average trait and "proportion variables" is estimated. And finally, in Model 3 , the existence of concave or convex relationships between average age and firm tenure and performance are estimated besides the impact of the control factors and "proportion variables". This hierarchical approach allows us to assess the unique contribution of the top management team variables in explaining agency performance.

\subsubsection{Top managers' human capiral and financral performance}

The results of the fixed-effects analyses testing the impact of the average trait and proportion variables on agency income and growth are summarized in Table 5.4. Columns (1) and (4) indicate that there are decreasing returns to scale in this industry and that firm growth decreasies with agency size. Furthermore, given the size of the agency, the size of the board is positively related to agency income and growth rates. This implies either that additional board members increase financial performance or that fewer board members decrease financial results. Location inside or outside the Kandstad and (partial) ownership by a large advertising firm do not affect agencies' financial results. Perhaps few firms moved from one region to the other and few agencies changed with respect to ownership (i.e., as measured here with a dummy variable), so that, in these fixed-effects analyses, the variables failed to have an effect 
on financial performance.

Table 5.4: Fixed-effect estimates of the impact of tean demographics on firm income and firm growh

\begin{tabular}{|c|c|c|c|c|c|c|}
\hline & \multicolumn{3}{|c|}{ Ageney lincome" } & \multicolumn{3}{|c|}{ Agency growth? } \\
\hline & (1) & 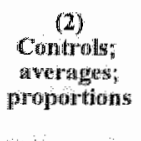 & $\begin{array}{l}\text { (3) } \\
\text { Controls: } \\
\text { averages: } \\
\text { avearsige } 2 \text {; } \\
\text { proportions }\end{array}$ & $\begin{array}{l}\text { Cy } \\
\text { Confrols }\end{array}$ & $\begin{array}{l}\text { (5) } \\
\text { Controlss: } \\
\text { wyerages, } \\
\text { proportions }\end{array}$ & 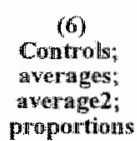 \\
\hline Lin (omplo) & $\begin{array}{l}655 \text { th } \\
(0.036)\end{array}$ & $\begin{array}{l}641 * 6 \\
(037)\end{array}$ & $\begin{array}{l}.579 \% * \\
(.040)\end{array}$ & & & \\
\hline Lu(ineorne & & & & $\begin{array}{c}-.274 \text { in } \\
(031)\end{array}$ & $\begin{array}{r}.28010^{*} \\
(.0311)\end{array}$ & $\begin{array}{c}-310 * * \\
(0,33)\end{array}$ \\
\hline Langarars) & $\begin{array}{l}.09010 \\
(.036)\end{array}$ & $.096 \%$ & $\begin{array}{l}.096^{* i k} \\
(037)\end{array}$ & $\begin{array}{l}.086 \% \\
(035)\end{array}$ & $089 \%$ & $\frac{.0833^{*}}{(.036)}$ \\
\hline $\begin{array}{l}\text { Ownership } \\
\text { liarge agdeticy }\end{array}$ & (1043) & $\begin{array}{l}.058 \\
\text { (.) } 489)\end{array}$ & $\frac{071}{(.047)}$ & $(077)$ & $\begin{array}{l}.085 \\
(046)\end{array}$ & $\begin{array}{l}.098 \% \\
(.646)\end{array}$ \\
\hline Rundstad & $\begin{array}{r}.092 \\
(.155)\end{array}$ & $\begin{array}{l}.038 \\
(.156)\end{array}$ & $\begin{array}{r}.026 \\
(.153)\end{array}$ & $(.065)$ & $(.149)$ & $\begin{array}{l}.669 \\
(.147)\end{array}$ \\
\hline Metan ange & & $\begin{array}{c}.002 \\
(005)\end{array}$ & $\begin{array}{r}.041 \\
(033)\end{array}$ & & $\frac{.001}{(.005)}$ & $\begin{array}{c}-0.018 \\
(.033)\end{array}$ \\
\hline $\begin{array}{l}\text { Mesau firma } \\
\text { lenure }\end{array}$ & & $\begin{array}{r}-601 \\
0006 !\end{array}$ & $\begin{array}{l}.030^{\mathrm{*at}} \\
(011)\end{array}$ & & $\begin{array}{l}-.002 \\
(.006)\end{array}$ & $\begin{array}{l}.024)^{\circ} \\
\text { (011) }\end{array}$ \\
\hline $\begin{array}{l}\text { Propartion } \\
\text { agency exp. }\end{array}$ & & $\begin{array}{c}009 \\
000)\end{array}$ & $\begin{array}{c}.011 \\
(.0099)\end{array}$ & & $\begin{array}{c}.006 \\
(.0099)\end{array}$ & $\begin{array}{c}009 \\
(009)\end{array}$ \\
\hline $\begin{array}{l}\text { Propontion } \\
\text { top exp. }\end{array}$ & & $\frac{-022^{* *}}{(.0088)}$ & $\begin{array}{l}.022 * * 0 \\
(.0088)\end{array}$ & & $\frac{-.015}{(008)}$ & $\begin{array}{r}.014 \\
6.018)\end{array}$ \\
\hline $\begin{array}{l}\text { Proportion } \\
\text { partiners }\end{array}$ & & $(005)$ & $\begin{array}{r}-.010 \\
(006)\end{array}$ & & $\frac{.002}{(.005)}$ & $\begin{array}{l}.002 \\
(.005)\end{array}$ \\
\hline 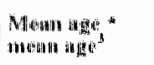 & & & 604 & & & $\begin{array}{l}.002 \\
(.6044)\end{array}$ \\
\hline $\begin{array}{l}\text { Mean Gentre } \\
\text { sitgeran fomatre }\end{array}$ & & & $\begin{array}{l}-.002 * * \\
(.00001)\end{array}$ & & & - 0005$)$ \\
\hline Anfli: $\mathrm{f}^{2}$ & $97 \%$ & . 799 & $.97 \%$ & .469 & .470 & 481 \\
\hline$T\left(\Delta \mathbb{B}^{\prime \prime}\right.$ & & 2.21 & 3.49:" & & 1.10 & 1.99 \\
\hline $\mathrm{N}$ & 38,4 & 384 & 384 & 371 & 37 & 371 \\
\hline
\end{tabular}

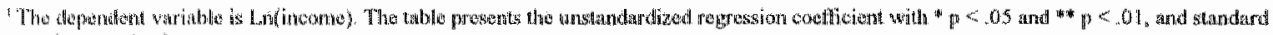
crros in fousenthessis.

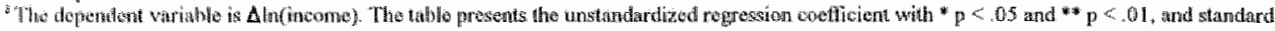
enor in parenthesis.

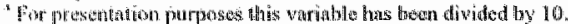

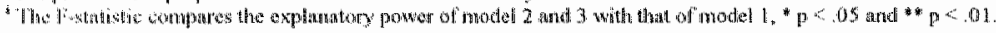

Hypothesis 1, expecting a concave connection between the average age of top managers and firm performance, is not supported by the results. The outcomes point to the absence of a linkage between this team attribute and the financial perfomance of advertising agencies (see, columns (2). (3), (5) and (6)). Consistent with Hypothesis 4 , average firm tenure within 
management teams has a concave relationship with the fitamcial performance of advertising firms. The effect is significant for both financial performance measures $(p<01)$. As expected, when advertising firms are headed by management teams with a "medium long" average firm tenure they generate higher revenues and growth rates, all other things equal, than when they are directed by short or long average tenured management teams. Calculation of the top of the curve indicates that when the average firm tenure of top executives is 9.7 years, firm productivity is highest, while agency growth reaches its peak when top managers have been with the agency for an average of 8.8 years.

The results provide no evidence for Hypothesis 7, expecting a positive relationship between the proportion of managers with experience at another agency and firm performance. This top management team wariable appears to be unrelated to the financial performance of advertising agencies. Hypothesis 8 , predicting a positive effect of the proportion of top executives with prior experience at a top agency on performance, is contradicted by the findings. Table 5.4 shows that, ceteris paribus, higher proportions of managers with top agency experience are negatively and significantly linked to firm income, and, although less strongly, also to firm growth $(\mathrm{p}=054)$. Hypothesis 9 , expecting a positive impact of the proportion of managerowners, is slightly contradicted for firm income, while no effect is observed witll respect to firm growth. Relatively more partners in the management team go hand in hand with lower firm revenues, all other things equal. The latter two results (Hypotheses 8 and 9), however, do not imply a negative effect of the proportion of managers with top agency experience and the proportion of owner managers on financial outcomes. They point to a comection only and these may very well be explained in line with the hypotheses. That is in combination with the positive relationship between board size and financial performance, two explanations may be put forward. First, during prosperous years the firms extend their boards with managers that do not possess top agency experience and that do not own shares in the company, so reducing the proportion of managers with top agency experience and the proportion of manager owners in their teams. Second, in years that agencies perform badly, executives without prior top agency experience and without company shares are expelled from the firm, so increasing the proportion of top agency experience and partners within the board.

The F-statistics of $\Delta \mathrm{R}^{2}$ indicate that for both financial performance indicators, Model 3 has the most explanatory power. However, the difference is significant for firm income only. These tests point out that demographic team atributes explain financial performance better than control variables alone, and, more specifically, a concave relationship of average firm tenure fits the data better than a linear linkage.

\subsubsection{Average rait and proportion variables affecting agency failure}

The outcomes of the analyses testing the influence of average trait and proportion variables on 
the probability of failure are presented in Table 5.5

Table 5.5: The effect of team demographics on whe probability of firm foilure

\begin{tabular}{|c|c|c|c|}
\hline & \multicolumn{3}{|c|}{ Firm fallure: } \\
\hline " & Conithols & $\begin{array}{l}\text { (2) } \\
\text { Controls; } \\
\text { averages; } \\
\text { proportiom }\end{array}$ & $\begin{array}{c}\text { (3) } \\
\text { Controls; } \\
\text { a verages } \\
\text { awerage } 2 ; \\
\text { proportions }\end{array}$ \\
\hline 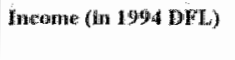 & $\begin{array}{r}-478 \\
(310)\end{array}$ & $(993)$ & $\begin{array}{r}-585 \\
(372)\end{array}$ \\
\hline Wous rid siste & $\frac{247}{(420)}$ & $\begin{array}{l}350 \\
(487)\end{array}$ & $\begin{array}{l}.842 \\
(.590)\end{array}$ \\
\hline Pircal age & $\begin{array}{l}.002 \\
(0,020)\end{array}$ & $\begin{array}{l}.020 \\
(025)\end{array}$ & $\begin{array}{c}.026 \\
(028)\end{array}$ \\
\hline $\begin{array}{l}\text { Ownership } \\
\text { lairge atgency }\end{array}$ & (.905 & $\begin{array}{c}657 \\
(1.196)\end{array}$ & $\begin{array}{l}1.270 \\
(1.369)\end{array}$ \\
\hline Mandetad & $\begin{array}{l}-2.11 \| * * \\
(.8811)\end{array}$ & $\begin{array}{l}-2.696 .1 \\
(1.241)\end{array}$ & $\begin{array}{l}-3.607 * \\
(1.590)\end{array}$ \\
\hline Nr wolyears in sumple & $\begin{array}{l}-0.082 \\
(1.66)\end{array}$ & $(.088)$ & $\begin{array}{r}-207 \\
(237)\end{array}$ \\
\hline Mean uge & & $\begin{array}{l}-.209 \\
(.120)\end{array}$ & $\begin{array}{r}-1.951 \\
(1.167)\end{array}$ \\
\hline Menn tenure & & $(113)$ & $\begin{array}{l}1.289 \\
(.667)\end{array}$ \\
\hline $\begin{array}{l}\text { Proportton agency } \\
\text { experience }\end{array}$ & & .067 & $\begin{array}{c}.069 \\
(.223)\end{array}$ \\
\hline $\begin{array}{l}\text { Proportion top agenoy } \\
\text { cxperience }\end{array}$ & & .233 & $\begin{array}{l}.173 * \\
(165)\end{array}$ \\
\hline Proportlom partiners & & .109 & $\begin{array}{l}433 \\
(258)\end{array}$ \\
\hline Mesmu unge meran age & & & $\begin{array}{c}188 \\
(128)\end{array}$ \\
\hline 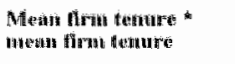 & & & $\begin{array}{r}-062 \\
(.037)\end{array}$ \\
\hline 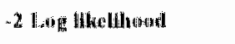 & 50,440 & 45.111 & 38.090 \\
\hline 4.2 l.sig Ilketllhood" & & -5329 & .12 .350 \\
\hline $\mathrm{N}$ & 77 & 77 & 77 \\
\hline
\end{tabular}

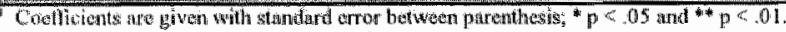

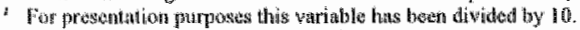

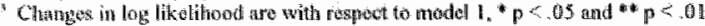

The analyses generate only slightly significant outcomes, which is probably due to the small sample size, implying a limited number of degrees of freedom. With respect to the control variables, the table reveals that advertising firms located outside the Randstad are more prone to die compared to their counterparts seated inside this region. Firm and board size, firm age and (partial) ownership by a large (multinational) adventising firm do not affect the probability 
of failure. The results provide no evidence for Hypothesis 1 and 4 , both predicting a concave connection between top managers' average age (H1) and average firm temure $(\mathrm{H} 4)$ and the probability of survival. When reestimating the regressions separately for average age and firm tenure, the outcomes remain insignificant. Both management team characteristics appear to be unrelated to the probability of survival.

Hypothesis 7, predicting a positive association of the proportion of top executives with prior experience at another agency and survival chances, is not supported by the findings either. This team variables is not connected to the probability of survival. The prediction that agency performance is enhanced by a larger proportion of board members with prior top agency experience (Hypothesis 8) is contradicted by the outcomes. Compared to survining lirms, agencies that failed during the time period under study, were headed by large proportions of board members possessing prior top agency expericnce, all other things equal. In combination with the results with respect to firm income, one may argue that the years prior to failure were characterized by low performance (see also Chapter 3) in which managers without top agency experience were expelled from the firm, so increasing the proportion of managers with top experience. However, the remaining experienced managers were probably not able to turn around the declining spiral and so the exiting firms were agencies with relatively many top experienced managers. Finally, the results provide no evidence for the predicted posilive association between the proportion of manager owners (Hypothesis 9 ) and failure chances. This top management team characteristic is unrelated to advertising firms' probability of failure. Since most effects are insignificant, it comes as no surprise that there is no significant difference between the goodness of fit of Model 1, Model 2 and Model 3.

\subsubsection{Team heterogeneity, interaction effects and agency performance}

In this section the results are summarized of (i) the effect of spread in top executives' age and firm tenure on agency performance (Hypotheses 2 and 5 ) and (ii) the impact of the interaction between average and spread in age and firm tenure on firm results (Hypotheses 3 and 6 ). The results are presented successively for financial performance, $i . e$. income and income growth (Table 5.6), and failure probability (Table 5.7). For each dependent variable, three regression equations are estimated. First, control variables, average trait and the "proportion variables" are analyzed. In the second model, control factors and spread variables are estimated. Finally, the third analysis tests the full model, adding the interaction variables to the equation.

The analyses presented in this section are based on all agencies with two or more board members. A minimum of two board members is necessary in order to be able to compute the standard deviation of the personal characteristics of the executives. Of the intial 384 obserwations in the sample, 85 refer to agencies that are headed by one top executive. These cases are, thus, excluded from the present analyses. The subsample of the firms with two or more board 
member's consists of 299 cases and 60 separate adwertising firms.

\subsubsection{Team heterogenety and interaction effects and financial performance}

Table 56 provides the results of the fixed-effects analyses testing the effect of the spread and interaction variables on the income and income growth of advertising agencies with two or more board members. Columns (1) and (4) correspond more or less to the results obtained for the whole sample, displayed in columns (3) and (6) of Table 5.4. Two differences with the previous analyses are noteworthy. First; the positive effect of additional board members has wantshed in the present subsample, revealing that while two or more executives generate more income and growth than one board member, all things equal, the additional value of more than two executives is not significant anymore. Second, the concave relationship between mean tenure and financial results observed among all agencies is, although in the predicted direction, not significant among the current subsample. We now proceed with the results on spread in age and tenure and the interaction effects, that is, Hypothesis $2,3,5$ and 6 .

Hypothesis 2 , predicting a positive connection between spread in top managers' age and firm performance, is supported by the results, when firm income is concerned. Heterogeneous management teams in terms of age achieve a higher agency income than age homogeneous boards, all other things equal. This finding is consistent with the so called diversity wiew. No effect of spread in age is observed with respect to firm growth. Hypothesis 5 , expecting a positive association between diversity in top executives' firm tenure and firm performance, is contradicted by the outcomes, for firm income. Opposite to the hypothesis, homogeneous management teams in terms of tenure obtain higher incomes compared to heterogeneously tenured teams, all other things equal. This result supports the facilitation perspective. Diversity in firm thenure appeared to be unrelated to agencies' growth rates.

In order to test Hypotheses 3 and 6 , two product terms were constructed (average age * spread in age and average firm tenure * spread in tenure). These product terms could be constructed as, within the present subsample, no significant convex or concave relationships are observed between the two average trait variables, age and tenure, and financial outcomes. Hypothesis 3, predicting that the impact of average age on performance is stronger among age homogeneous teams, is not confirmed by the findings. Since spread in age, but not average age, revealed to be positiwely related to firm income, a confitmation of Hypothesis 3 could, for this performance indicator, not be expected. Table 5.6 points out that there is no interaction effect at all between average and spread of age on agency performance. When excluding firm tenure from the analysis, the interaction effect of average and spread in age remains insignificant.

Hypothesis 6 , foreseeing that the effect of average firm tenure on performance is stronger among tenure homogeneous teams, is supported by the results when firm growth is concerned 
Table 5.6: Fixed-effect estmates of the impact of spread in age and fim remore on fint income and firm growth

\begin{tabular}{|c|c|c|c|c|c|c|}
\hline & \multicolumn{3}{|c|}{ Agency income } & \multicolumn{3}{|c|}{ Agency growth: } \\
\hline & $\begin{array}{l}\text { (1) } \\
\text { Controls } \\
\text { averages } \\
\text { nveragez; } \\
\text { proportions }\end{array}$ & $\begin{array}{c}\text { Controls" } \\
\text { sponesuds }\end{array}$ & $\begin{array}{l}\text { (3) } \\
\text { Controls; } \\
\text { averanges; } \\
\text { spreats: } \\
\text { inferactions; } \\
\text { proportions }\end{array}$ & $\begin{array}{c}\text { (4) } \\
\text { Controls; } \\
\text { avertuges; } \\
\text { avrorage? } \\
\text { proportions }\end{array}$ & $\begin{array}{l}\text { (S) } \\
\text { Coningls; } \\
\text { spreats }\end{array}$ & 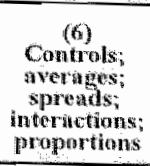 \\
\hline $\ln (\operatorname{sen} p)$ & $\begin{array}{l}.641^{* *} \\
(0.45)\end{array}$ & $\begin{array}{l}.660 * * \\
(040)\end{array}$ & $\begin{array}{l}.677 \times 2 \\
6041\end{array}$ & & & \\
\hline 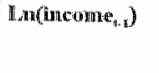 & $=$ & & & $\frac{-19)^{\circ}}{(030)}$ & $\begin{array}{l}-m_{1} 194 * * * \\
(029)\end{array}$ & $\begin{array}{c}-191 \% * \\
(1.03010)\end{array}$ \\
\hline Lan(bosard) & $\begin{array}{l}088 \\
0.052)\end{array}$ & $\begin{array}{r}.073 \\
(.048)\end{array}$ & $\begin{array}{c}051 \\
(053)\end{array}$ & .089 & $\frac{1.12 *}{0.047}$ & $\frac{.052}{(0.00)}$ \\
\hline $\begin{array}{l}\text { Ownership } \\
\text { large agency }\end{array}$ & $\begin{array}{l}079 \\
(058)\end{array}$ & $\begin{array}{c}.067 \\
(.059)\end{array}$ & $\begin{array}{c}.064 \\
(.059)\end{array}$ & $\begin{array}{c}237^{* * *} \\
(0,56)\end{array}$ & $\begin{array}{l}.246 * * \\
(.054)\end{array}$ & $\begin{array}{l}206 \mathrm{stt} \\
(055)\end{array}$ \\
\hline Mkardestad & $\begin{array}{l}.042 \\
(154)\end{array}$ & $\begin{array}{r}115 \\
(153)\end{array}$ & $\begin{array}{l}.064 \\
(.157)\end{array}$ & $\frac{682}{(154)}$ & $\begin{array}{l}048 \\
(152)\end{array}$ & $\begin{array}{l}.062 \\
(.154)\end{array}$ \\
\hline Mearl age & $\begin{array}{r}.013 \\
(044)\end{array}$ & & 0.003 & $\begin{array}{c}.012 \\
(044)\end{array}$ & & cons \\
\hline 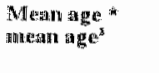 & $(0052)$ & & & $\frac{-.002}{(.005)}$ & & \\
\hline $\begin{array}{l}\text { Meam firm } \\
\text { teature }\end{array}$ & $\begin{array}{l}.016 \\
(.013)\end{array}$ & & $\begin{array}{l}.0005 \\
(008)\end{array}$ & $\begin{array}{l}-0001 \\
(0013)\end{array}$ & & $\begin{array}{l}-.014 * \\
(.007)\end{array}$ \\
\hline $\begin{array}{l}\text { Megan temente } \\
\text { moan tenure }\end{array}$ & $\begin{array}{l}-.001 \\
0.001)\end{array}$ & & & $\begin{array}{l}-.001 \\
(.001)\end{array}$ & & \\
\hline $\begin{array}{l}\text { Proportion } \\
\text { agency exp. }\end{array}$ & $\begin{array}{c}.006 \\
(.010)\end{array}$ & & $\begin{array}{l}.0002 \\
(0012)\end{array}$ & $\begin{array}{l}.0004 \\
6.010)\end{array}$ & & $\begin{array}{l}-605 \\
0010)\end{array}$ \\
\hline $\begin{array}{l}\mathbb{P}^{2} \text { rop top } \\
\text { agency exp. }\end{array}$ & $\left(.028^{* *}\right.$ & & $\begin{array}{l}.019 \% \\
0.011)\end{array}$ & $(0009)$ & & (.007 \\
\hline $\begin{array}{l}\text { Proportion } \\
\text { parturess }\end{array}$ & $\frac{.019 \%}{(006)}$ & & $\begin{array}{l}.017 \% \\
(007)\end{array}$ & $\begin{array}{c}003 \\
(006)\end{array}$ & & $\begin{array}{r}.003 \\
(.006)\end{array}$ \\
\hline $\mathrm{SD}$ age & & (1.007) & $\begin{array}{l}0162 \\
(068)\end{array}$ & & $\begin{array}{r}007 \\
0060)\end{array}$ & $(11)$ \\
\hline SD tonme & & $\frac{0.023 \times}{(.008)}$ & $\begin{array}{l}-016 \\
(015)\end{array}$ & & -.004 & $\begin{array}{l}-130 \% \\
(01404)\end{array}$ \\
\hline $\begin{array}{l}\text { Meins age* } \\
\text { SD age }\end{array}$ & & & $(00011$ & & & $\frac{.002}{(002)}$ \\
\hline $\begin{array}{l}\text { Mean temure } \\
\text { " SD tenure }\end{array}$ & & & .0002 & & & ond \\
\hline Adj. $\mathrm{I}^{\mathrm{t}}$ & .976 & 975 & .976 & .464 & .460 & 48 \\
\hline$F\left(\Delta R^{2}\right)^{2}$ & $2.64^{*}$ & 4.28 & $2.24 *$ & 1.15 & 60 & 190 \\
\hline N & 299 & 299 & 299 & 290 & 294 & 294 \\
\hline
\end{tabular}

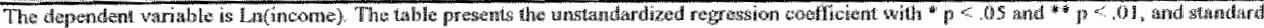
arors in parenthesis

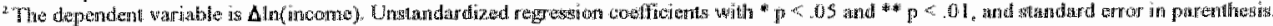

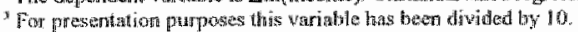

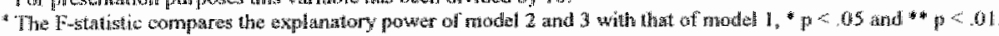


The findings indicate that a negative impact of mean tenure on growth is stronger in tenure homogeneous teams than in tenure heterogeneous teams. When average firm tenure of board members is low, homogeneity in this characteristic enhances frrm growth. However, when average firm tenure is high, spread in tenure is beneficial for firm growth. The change in the effect occurs at an average firm tenure of 12,1 years. Teams with longer average tenures benefit from diversity in this characteristic, whereas shorter average firm tenures profit from homogeneity in this personal atribute; For firm growth, Model 3, the full model, including the interaction terms, has more explanatory power than Models 1 and 2. The tests indicate that an interaction between average and spread in tenure accounts better for agency growth than the two team characteristics separately.

\subsubsection{Team heterogeneity, interaction effects and agency failure}

The effects of the spread and interaction of average and spread in age and firm tenure on the probability of agency failure (Hypotheses 2, 3,5 and 6) are presented in Table 5.7. Since the sample diminished to 60 advertising firms and only 5 agencies ( 12 percent) exited the data set during the time period under study, not each of the three analyses could be carried out as desired. The result is that Model 1 estimates the impact of the control factors, the proportion wariables and average age and tenure, but not the possibility of concave or convex connections. Model 2 includes the control and spread variables. Finally, Model 3 analyzes the control factors, the average and spread variables of age and tenure, as well as their interactions, but excludes the proportion variables.

The outcomes presented in collumn (1) of Table 5.7 show that the impact of the control, average and proportion variables correspond more or less to the results displayed in Table 5.5. That is, the signs of the connections are similar, although within the current sample the region and top agency experience effects are not significant anymore. Furthermore, columns (2) and (3) show that none of the tested hypotheses, that is Hypotheses 2, 3,5 and 6, are supported by the results. Spread in age and tenure as well as the interaction between average and diversity in these two team characteristics appear to be unrelated to advertising agencies' survival chances. The restricted sample and the small number of exiters may have been two of the causes of the insignificant lindingst. 
Table 5.7: The effect of spread in age and firm temure on firm failure'

\begin{tabular}{|c|c|c|c|}
\hline & \multicolumn{3}{|c|}{ Firm failure } \\
\hline & $\begin{array}{l}\text { (1) } \\
\text { Controls; } \\
\text { awerages; } \\
\text { proportions }\end{array}$ & $\underset{\substack{\text { Conhrobis; } \\
\text { spreads }}}{(2)}$ & $\begin{array}{l}\text { Controks } \\
\text { averages; } \\
\text { sppreats } \\
\text { inforractions }\end{array}$ \\
\hline Ineame (in 1994. DFL) & $\begin{array}{l}-779 \\
(.868)\end{array}$ & $\begin{array}{l}-996 \\
(589)\end{array}$ & $(905)$ \\
\hline Bourd size & $\begin{array}{l}(2.227) \\
(1.286)\end{array}$ & $\begin{array}{l}1.742 \\
\{.983)\end{array}$ & $(1.314$ \\
\hline Firm age & $\begin{array}{l}.107 \\
(.068)\end{array}$ & $\begin{array}{l}.006 \\
(.037)\end{array}$ & $\begin{array}{l}.021 \\
(.058)\end{array}$ \\
\hline Ommership large agency & $(2.067)$ & $\begin{array}{c}590 \\
(1.604)\end{array}$ & $\begin{array}{c}596 \\
2.255)\end{array}$ \\
\hline Randstad & $(3.4378)$ & $\begin{array}{l}-4.179 \\
(2.651)\end{array}$ & $\begin{array}{l}-5.878 \\
(4.449)\end{array}$ \\
\hline Nr of years in sample & $\begin{array}{l}.025 \\
(3.342)\end{array}$ & $(273)$ & $(.075)$ \\
\hline Mean age & (274) & & $\begin{array}{l}.125 \\
(.445)\end{array}$ \\
\hline Mean tenure & $\begin{array}{l}.255 \\
(.3844)\end{array}$ & & -264 \\
\hline $\begin{array}{l}\text { Propartion agency } \\
\text { experientue }\end{array}$ & $\begin{array}{l}1.408 \\
(.969)\end{array}$ & & \\
\hline $\begin{array}{l}\text { Propartion top agensy } \\
\text { experience }\end{array}$ & $\begin{array}{l}1006 \\
(.315)\end{array}$ & & \\
\hline Proportion parmers & $\begin{array}{l}.415 \\
(.437)\end{array}$ & & \\
\hline SD age & & $\begin{array}{l}.537 \\
(300)\end{array}$ & $\begin{array}{l}1.551 \\
(3.046)\end{array}$ \\
\hline SD finu temure & & $\begin{array}{l}.023 \\
(270)\end{array}$ & $\begin{array}{l}-1.164 \\
(1.312)\end{array}$ \\
\hline Mean age " $\mathrm{SD}$ age & & & $(0.019)$ \\
\hline Mean tenure " SD temure & & & $\frac{(120)}{(130)}$ \\
\hline-2 Log likelihwood & 18.489 & 21.648 & 18.890 \\
\hline$\Delta-2 \operatorname{Lag}$ likwtihowdi ${ }^{2}$ & .8380 & .5 .221 & -7.979 \\
\hline$N$ & 60 & 60 & 60 \\
\hline
\end{tabular}

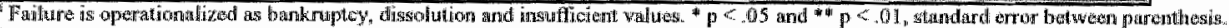

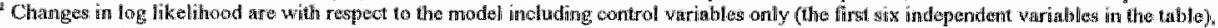

$p<05$ and * $p<01$

\subsection{Discussion}

In Table 5.8, the hypotheses that are tested in this chapter and the outcomes are summarized Results refer to the whole sample for average age, tenure and proportion variables. For spread and interaction variables, the outcomes are based on the subsample of agencies with at least 
two board members. The nost striking resuls are discussed below.

Table 58: Swmany of resuls

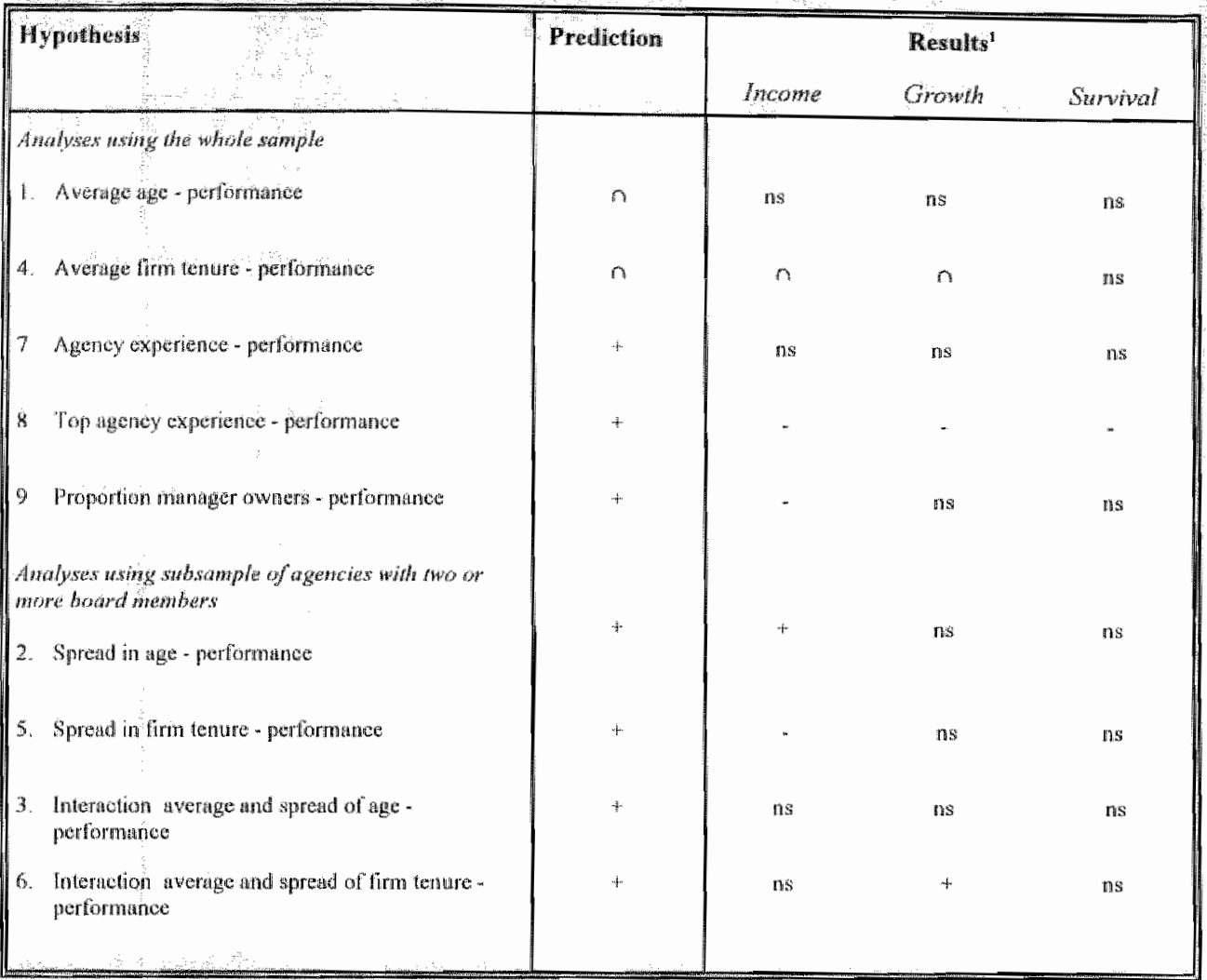

While top managenent team members" age and firm tenure are correlated, and the two trait. variables were expected to have similar effects on agency performance, the estimates reveal that (i) average firm tenure is more often significantly related to agency performance than age, and (ii) the two characteristics sometimes have an opposite effect on agency performance (i.e., spread in age and tenure). The first outcome is consistent with the consideration that firm tenure has the best theoretical basis of all demographic variables (Pfeffer, 1983) and the second result supports the comment by Pfeffer $(1983$ : 305) that "there is enough vartance not in common anong the concepts to argue that they are conceptually distinct and should be kept so in both theoretical and empirical analysis".

The interaction effect of average and spread in firm tenure on growth rates seems, at first glance, to contradict the concave relationship between average temure and growth. However, one must keep in mind that the interaction effect refers to agencies with at least wo board 
members, whilst the concave tenure linkage was not significant anongst these firms: When agencies have two or more board members, income growth rates are strongly affected by a combination of the average and spread in firm tenure of top managers. Short tirm tenured managenent teams can do without diversity in this characteristic, since the performanceenhancing skills associated with short firm tenure are largely avallable in the team. However, within long tenured teams, the necessary competencies for effective management are not available, so that diversity in this attribute increases performance. "That is, a greater dispersion implies that one or several managers in the tean have relatively short firm tenures, so ensuring the important features associated with this demographic characteristic. Furthermore; why should especially income growth be affected by this interaction effect? Probably because the skills associated with short firm tenure, such as a bigher propensity for strategic change and risky decisions, are necessary for obtaining high growth rates, but are not essential for a thigh income and survival.

The proportion of top executives with prior experience at another agency does not affect firm performance. The absence of a significant association is probably due to the fact that, on average, the proportion is very high and only minor changes in this characteristic occur within teams. However, the proportion of executives with experience at a top agency produced a negative relationship with firm performance, instead of the predicted positive linkage. A similar outcome is observed with respect to the proportion of manager owners in the board. Instead of an expected positive impact of the proportion of manager owners on firm outcomes, the analyses have produced a weak negative linkage with firm income. Increasing the proportion of manager owners seems to be related to a lower income. When interpreting these results one must keep in mind that the findings imply a connection, but do not allow us to infer the existence of a causal relationship. In combination with the positive linkage between board size and financial performance, several explanations were forwarded for these negative connections, pointing in fact to a positive impact of top agency experience and partnership on financial results. First, during prosperous years firms extend their boards with managers that do not possess top agency experience and that do not own shares in the company, so reducing the proportion of managers with top agency experience and the proportion of manager owners in their teans. Second, in years that agencies perform badly, executives without prior top agency experience and without company shares are expelled from the firm, so increasing the proportion of top agency experience and partners within the board. In view of the positive relation ship between top agency experience and failure, the latter situation seems most realistic. That is, after expelling the managers without top experience, the remaining managers were probably not able to turn around the declining spiral and so exiting firms were agencies with relatively many top experienced managers.

With respect to financial results, the analyses generated many significant relationships. 
However, the fact that not more significant findings are observed may be caused by the applied analyses. In order to assess the impact of team demographics on financial performance, fixedeffects are estimated. Fixed-efects models constitute wery conservative tests of the hypotheses. They may have falled to produce more pronounced outcomes as only small changes in team composition occur, especially in the average and spread of age and tenure, and since the time period the fims are included in the data set covers only a few years. In future studies, other analyses may be wndertaken that concentrate on between firm variance.

The effect of team make up on survival chances has revealed to be rarely significant. Again, the applied analyses may be held responsible. The logistic analyses compare the team composition of failing agencies with the make up of surviving firms. While this exercise gives a good insight into the relative team characteristics of exiters in the years preceding failure, taking the average values of firms over the years, as in these analyses, implies a loss of many degrees of freedom. Furthermore, the time aspect is not taken into account. Unfortunately, hazard models could not be estimated here, due to too much left and right censoring. If the data set could be enlarged, future analyses could include the time aspect and make use of all firm-year observations by carrying out, e.g., event history analysis.

The fact that several hypotheses are contradicted by the findings together with the inconsistencies in the results of former studies seems to indicate that top management team composition theory (in terms of age, tenure and experience) has a less universal character than is often assumed. While industry contingencies direct the formulation of industry-specific hypotheses, the latter appear to be difficult to formulate. This may be caused by the fact that theorizing on the top management team composition - performance linkage is based on many unquestioned assumptions about intermediate factors. It is, then, questionable whether the theory is a good reflection of reality. One may wonder whether we refer to the exact underlying factors, and whether these always relate to performance or strategies as assumed. For instance, does age refer to conservatism in strategies, and in tum, does this imply low performance? While this seems plausible, research findings do not always support this reasoning. This argument implies that, besides attributing the insignificance of results to the applied analyses, they may also be attributed to the questionability of the strength of the direct relationship between team composition and firm performance. In future studies, it is, therefore, important to examine the intermediate factors between personal characteristics and advertising firm performance as well.

\subsection{Conclusions}

This study was designed to examine the impact of top management team composition on both financial performance and survival chances of agencies, and to estimate the possible interaction effect of average and spread of team variables on firm outcomes. The results demonstrate that management team composition partly cietermines advertising agency performance. Financial 
performance of advertising firms is related to average and spread in firm tenure, diversity in age, top agency experience and partnership. Sumival chances are influenced by top agency experience of managers. Moreover, this study has proven that it is worthwilile to estimate interaction effects of average and spread in team attributes on firm performance. Growth rates of advertising agencies are influenced by an interaction between average and spread of firm tenure. When average firm tenure is short, homogeneity in this characteristic enhances financial performance, and when average firm tenure is long, diversity increases performance.

Unexpected and insignificant outcomes may be due to the severeness of the applied analyses and the questionability of the viability of the direct relationship between top management team composition and firm performance. Future analyses could concentrate more on between-firm differences and, if the current data set can be extended, should include analyses that take account of the time aspect. Furthermore, intermediate factors between team composition and firm performance should be examined in these studies as well.

As this study is conducted in a single industry, the results may not be generalizable to other industries. Moreover, the present study included a restricted subsample of the total research sample used in previous chapters: it is unclear in what respect this subset differs from the unstudied agencies as to the relationship between team composition and agency performance. One should, therefore, even be careful in generalizing the outcomes presented in the present study to the other agencies in the research sample. 


\section{CHAPTER 6}

\section{SUMMARY OF CONCLUSIONS}

\subsection{Introdaction}

The purpose of this thesis was to examine the effect of a set of determinants of business success in the Dutch advertising industry, in the period $1984-1994$, addressing three levels of analysis: the industry, the organization and the top management team level. At the industry level, a descriptive approach is applied by investigating market structure and industry dynamic issues. The two lower levels of analyses are dealt with by studyng the effect of organizational change and management capital on advertising firm performance. In order to assess the importance of organizational size in the first relationship, analyses are undertaken separately for small and large firms. Moreover, three measures of organizational performance are examined in all analyses: firm income, income growth and the probability of fallure.

This final chapter summarizes the findings of the previous chapters and presents suggestions for future research. The results of the empirical chapters are summarized without referring to theories or advancing alternative explanations as the separate chapters have done this extersively. The chapter is organized as follows. Section 6.1 summarizes the empirical findings along the framework presented in Figure 1.1. Section 6.2 goes into the relationship between the three performance measures and their reliability. Section 6.3 draws several conclusions. Section 6.4 explains the contribution of the study to the existing literature. Finally, Section 6.5 presents suggestions for future research.

\subsection{Summary of empirical results}

The summary of the empirical results is structured according to the framework presented in Figure 1.1. Figure 6.1 reproduces the framework of Chapter 1 and indicates the bypotheses (or chapters) pertaining to the different effects. For each of the relationships addressed in this book, Tables $6.1-6.4$ present the hypotheses and empirical outcomes. Linkages that are studied without being specifically tested as hypotheses are included in the tables and discussion as well. This section starts with an overview of the industry structure and dynamics findings, and proceeds with a summary of the effects of organizational structure, strategy and top management team characteristics on advertising agency performance.

\subsubsection{The inchustry structure and dynamics}

The structure and dynamics of the Dutch advertising industry are examined in Chapters 2 and 


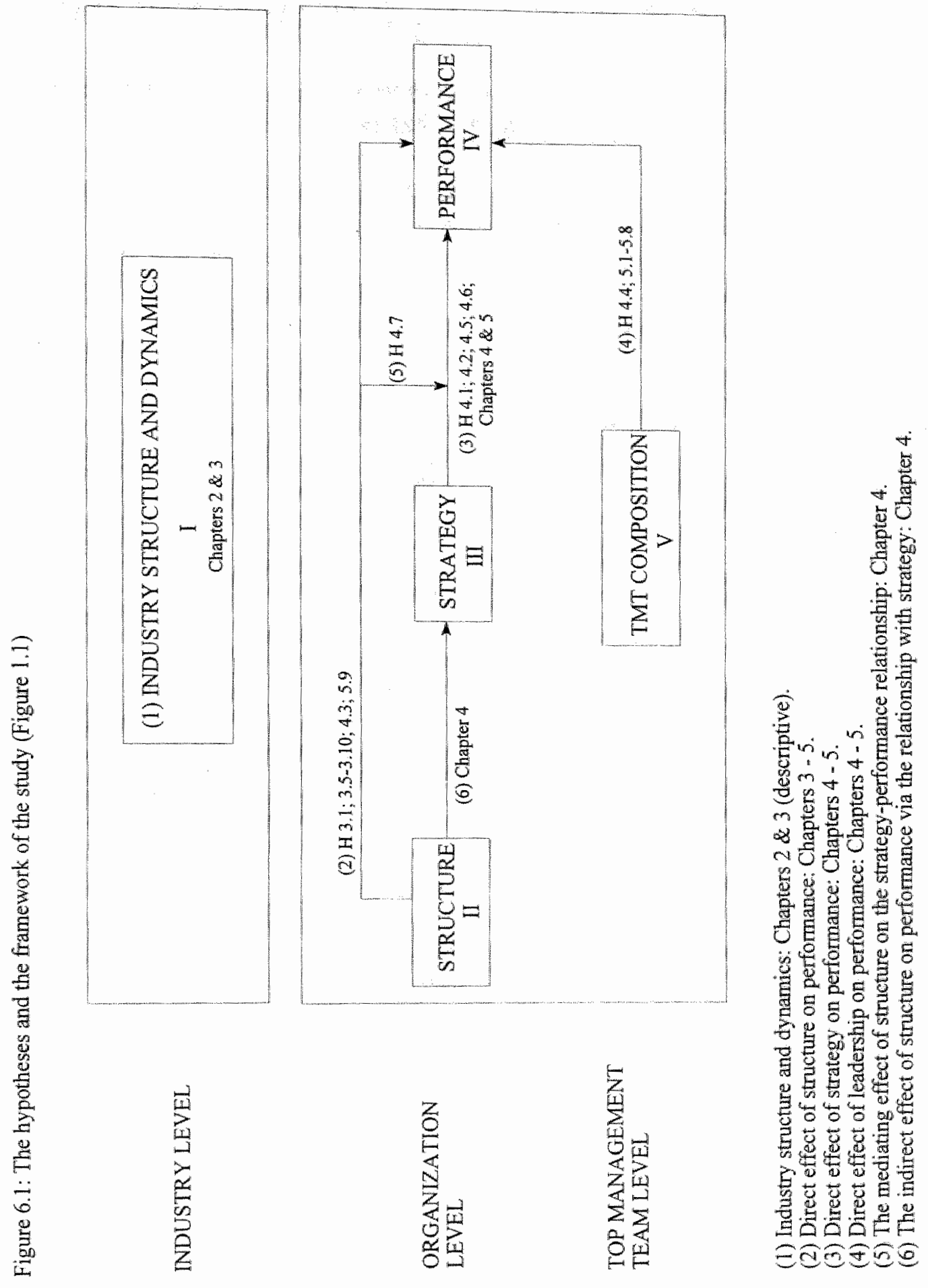


3, respectively. Chapter 2 describes the density, concentration level and top-ten ranking during the 1984 - 1994 period. Chapter 3 studies the entry and exit rates, the (pattern of) market shares and relative size of entrants and exiters over the period under study. The industry structure examination has indicated that the Dutch industry of advertising agencies consists of a huge number of firms with, however, only a limited number of these having a reasonable size (a minimum of 3 employees). This upper segment of the industry, which is almost fully captured in the current sample, has grown steadily over the years under study. The advertising industry is a moderately concentrated market. The market shares of the four largest individual agencies in the industry vary between 11 and 13 percent over the $1984-1994$ period. The four largest agency groups take account of about 20 percent of total sample income in each of these years. The $\mathrm{C}_{4}$, both of individual agencies and agency groups, remains very stable over the eleven years under study. The same stability is observed for the top-ten rankings of individual agencies and agency groups, between 1984 and 1994 . In nearly all years, the advertising firm FHV/BBDO, or in group terms, BBDO Nederland, occupies the first place in the rankings. While it is extremely difficult to penetrate the segment of top agency groups, a few independent agencies have succeeded in obtaining a position among the individual top ten of advertising agencies.

The Dutch advertising industry is a dynamic market. The mean entry and exit rates, in the upper market segment, during the 1984 - 1994 period are 7.33 and 4.35 percent, respectively. The average annual market shares of entrants and exiters are both about 3 percent. Exiting firms are, thus, somewhat larger compared to entering companies. On average, newcomers are about 40 percent of the size of incumbent firms. The relative average size of exiters, on the other hand, is almost 80 percent of the size of survivors. Especially the firms that exit because of a merger, appear to be relatively large. Indeed, several mergers between top-ten agencies have taken place during the time period under study.

Most newly established agencies are independent firms, owned by their managers. Entrants perform rather well. Nine years subsequent to entry, surviving entrants have about reached the average size of incumbents. Moreover, compared to the percentage of failures among incumbents, a small percentage of newcomers dies within the first nine years after entry. Most failures in the $1984-1994$ period are, similar to the new establishments, small and independent advertising firms. Exit is preceded by low productivity lewels. However, growth rates are not particularly low in the years prior to failure. Agencies that exit because of a merger or acquisition, perform relatively well in the years preceding this event, also in comparison with surviving firms. Their penformance made them attractive candidates for merger or take-over.

\subsubsection{The direct impact of organizational structure on agency performance}

The aspects of organizational structure examined in this book are firm size, board size, (partial) 
ownership by a larger advertising firm, the proportion of ownermanagers, change in ownership structure and firm age (see Table 6.1). Although tirm age is not an aspect of frm structure, it is discussed in this section since it is even less an aspect of competitive strategy or management capital. The impact of organizational structure on agency performance is assessed in Chapters 3,4 and 5. In the latter two chapters most of these factors are taken along as control variables. While the samples and analyses differ somewhat between the chapters, the results with respect to the structure aspects are rather robust.

The outcomes of chapters 3 - 5 reveal that firm income increases with agency size, whereas growth rates diminish with the size of the firm. These findings are consistent with theory and prior research (see, e.g., Evans, 1987; Dunne and Hughes, 1994; Doms et al, 1995). While Chapter 3 has shown that large agencies have higher survival chances than small advertising firms, this positive relationship is not significant in later chapters when additional factors (board size and ownership by a large advertising firm) are controlled for. Younger advertising firms achieve higher productivity levels and higher growth rates than older advertising companies of the same size. Firm age is not related to failure chances.

Board size is positively connected to financial performance, both income and income growth of especially large advertising agencies. Small firms that exited the data base had, on average, more board members during the time period they were in the sample than surviving agencies of the same size. Growth rates tend to be higher when the agency is (partially) owned by a large advertising firm. And, finally, agency income decreases with larger proportions of manager owners, all other things equal. While the latter finding may seem surprising, one must keep in mind that the results involving financial performance presented here are based on fixedeffects analyses, estimating within-firm variation. When comparing performance differences bemeen firms different relationships may occur. The combination of the impact of board size and the proportion of owner managers on performance may be explained as follows. In years of low performance, agencies reduce the size of their boards by expelling non-owners, perhaps because of bad performance, so reducing the size of the board while at the same time enhancing the proportion of manager-owners within the team. Finally, changes in ownership structure do not influence the performance of advertising companies.

\subsubsection{The direct effect of strategy on advertising agency perfornance}

Strategic aspects that are investigated in this book are (changes in) location, client diversity, media service diversity and agency name. The effect of location in the Randstad on firm performance is assessed in Chapters 4 and 5 , as the variable was taken along as a control factor. The impact of the other strategies and strategic changes on agency success was examined in Chapter 4 . The empinical results of the effects are summarized in Table 6.2. 
Table 6.1: The direct effect of organizational strwcture on firm performance.

\begin{tabular}{|c|c|c|c|c|}
\hline \multicolumn{5}{|c|}{$\begin{array}{l}\text { DIRECT EFFECT: } \\
\text { ORGANIZATIONAL STRUCTURE-PERFORNANCE }\end{array}$} \\
\hline & Prediction & & Resillts & \\
\hline Hypotheres and reltutionships not tested as liypotheses & & $\begin{array}{l}\text { All } \\
\text { ageneries }\end{array}$ & $\begin{array}{l}\text { Sintuall } \\
\text { agericiss }\end{array}$ & $\begin{array}{l}\text { Large } \\
\text { agrencies }\end{array}$ \\
\hline 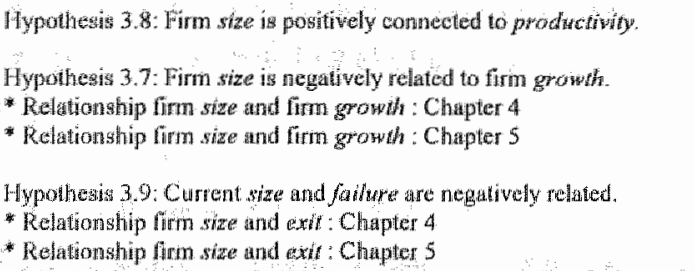 & + & $\begin{array}{l}+ \\
- \\
-\end{array}$ & nhas & IBS \\
\hline 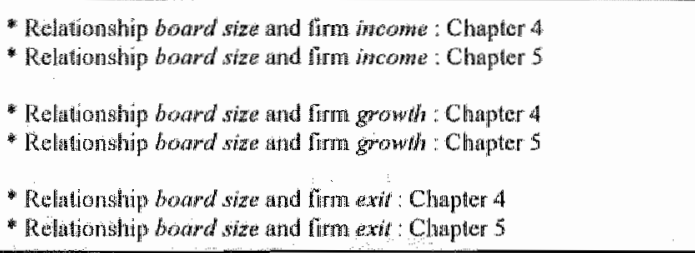 & & $\begin{array}{l}4 \\
+ \\
+ \\
n\end{array}$ & $\begin{array}{l}+ \\
+4 x^{2} \\
+\end{array}$ & $\begin{array}{l}+ \\
+ \\
+15\end{array}$ \\
\hline 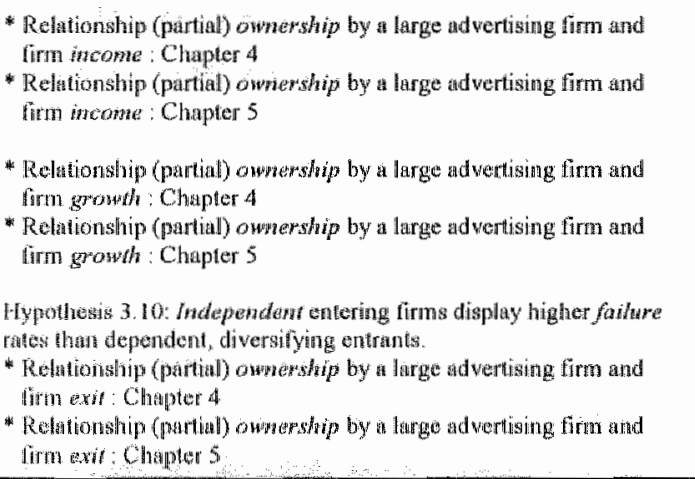 & * & nis & not tested & $\begin{array}{l}\text { ns } \\
\\
\text { nes }\end{array}$ \\
\hline 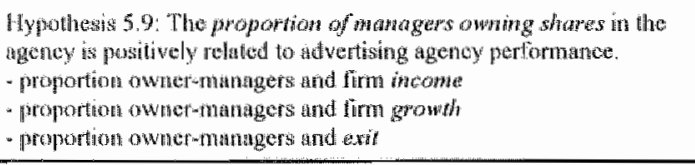 & $\begin{array}{l}* \\
+ \\
.\end{array}$ & ns & & \\
\hline 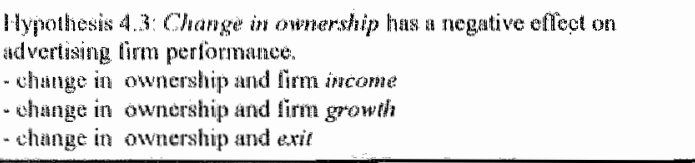 & + & & $\begin{array}{l}n s \\
n s \\
n\end{array}$ & $\begin{array}{l}\text { ns } \\
\text { Mis } \\
\text { nas }\end{array}$ \\
\hline 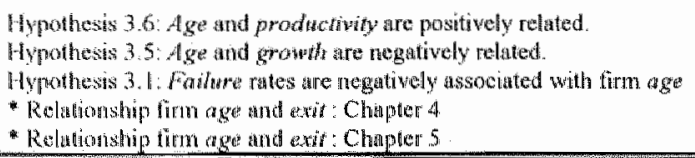 & + & ns & 01,15 & MS \\
\hline
\end{tabular}


Table 62: The direct effect of strategy on fim perfomance

\begin{tabular}{|c|c|c|c|c|}
\hline \multicolumn{5}{|c|}{$\begin{array}{c}\text { DTRECT LARET: } \\
\text { STRATEGY - PERTORMANCE }\end{array}$} \\
\hline & & \multicolumn{3}{|c|}{ Results } \\
\hline Hypotheses & Prediction & $\begin{array}{l}\mathrm{AH} \\
\text { agrondids }\end{array}$ & $\begin{array}{l}\text { Sonnd } \\
\text { agmoner }\end{array}$ & 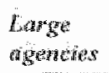 \\
\hline 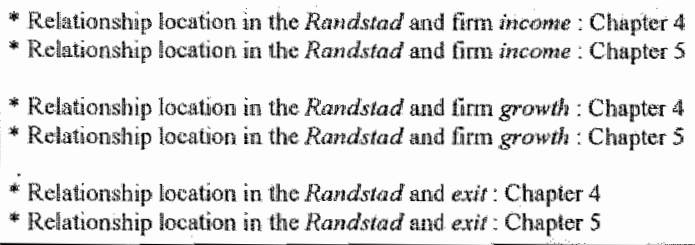 & 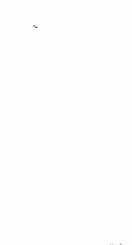 & ns & $\begin{array}{l}+ \\
+ \\
+\end{array}$ & $\begin{array}{l}\text { not tested } \\
\text { not tesited } \\
\text { ns }\end{array}$ \\
\hline 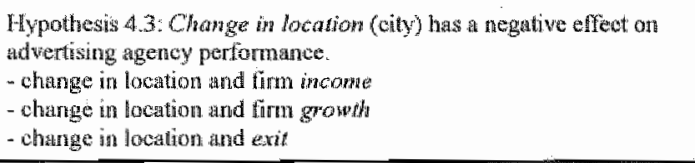 & 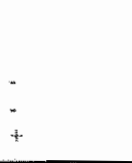 & & nsis & 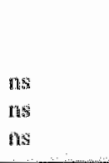 \\
\hline 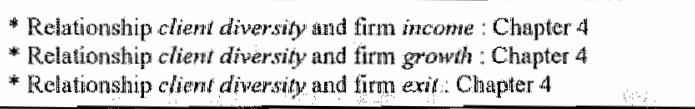 & & & nis: & ns \\
\hline 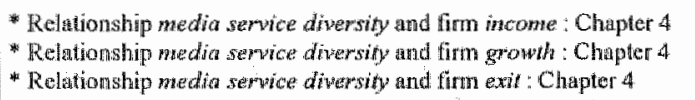 & & & Mis & $\begin{array}{l}- \\
\text { ass } \\
\text { H1s }\end{array}$ \\
\hline 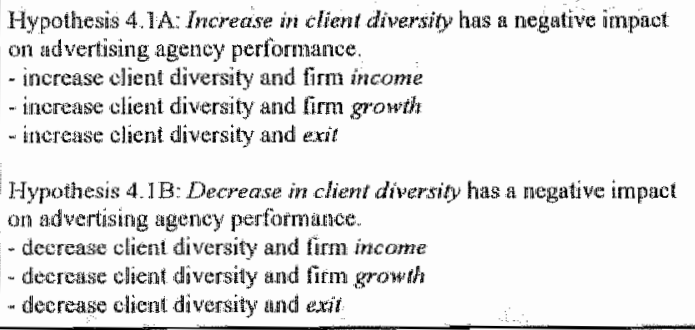 & $\begin{array}{l}* \\
* \\
*\end{array}$ & & 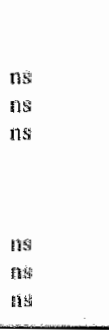 & $\begin{array}{l}\text { ns } \\
\text { nis } \\
n s\end{array}$ \\
\hline 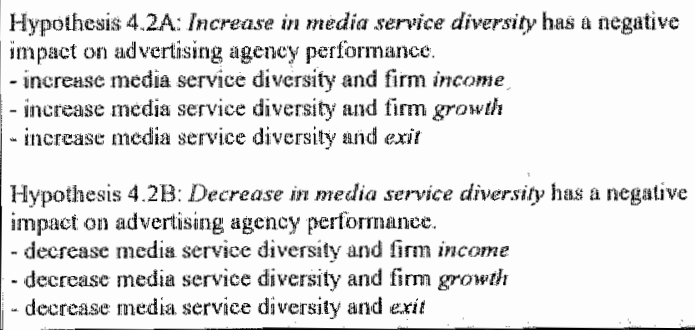 & . & & 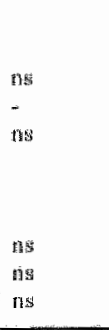 & 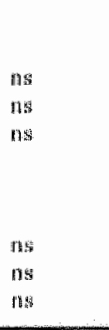 \\
\hline 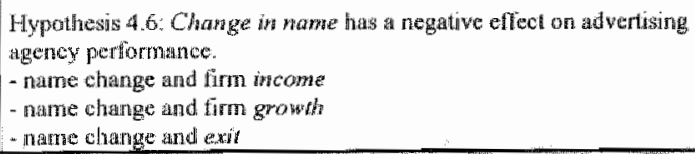 & $\begin{array}{l}- \\
- \\
\end{array}$ & & $\begin{array}{l}\text { nas } \\
+ \\
13\end{array}$ & $\begin{array}{l}\text { ns } \\
- \\
013\end{array}$ \\
\hline
\end{tabular}


The outcomes have revealed that when small advertising firms are located in the Randstad, they obtain more income and higher growth rates than when they are seated in other regions of the Netherlands. Moreover, all agencies have a lower probability of failure when located in the Randstad. The impact of location in the Randstad on the financial performance of large agencies could not be assessed with the fixed-effects analyses since not enough large firms moved from one region to the other during the time period they are included in the sample. Moving the firm to another city (either inside or outside the region in which the agency is seated) harms growth rates of small advertising agencies, but does not seriously affect large advertising agency performance.

While the performance of advertising agencies remains unaffected by the extent of client diversity, media service diversity is negatively related to firm income of large agencies and survival chances of small agencies. For large agencies more specialization in the diversity of media services appears to be beneficial for their revenues. However, small advertising firms that exited the data set were, relative to their surviving counterparts, characterized by a specialized offer of media services.

Given the current level of client and media service diversity, increases and decreases in these strategic positionings hardly affect firm performance. The only significant effect pertains to increases in media service diversity decreasing small agencies' growth rates. The relatively small changes in the service diversity measures experienced by the advertising firms under study have, probably, caused the lack of more significant findings. Finally, after a name change has taken place, the growth rate of small agencies significantly increases, while the growth pace of large advertising firms significantly decreases, which may point to more radical underlying internal transformations in large than small firms.

\subsubsection{The direct effect of leadership on advertising agency performance}

The impact of management capital on advertising agency performance was the subject of Chapter 5. Top executives" age, firm tenure and experience were related to firm performance. In addition, Chapter 4 examined the effect of top management team mutations on performance. Table 6.3 summarizes the findings. The outcomes reveal that firm revenues and growth rates have a concave relationship with the average firm tenure within the top management team. Firm income is highest when the average firm tenure in the team is 9.7 years, while growth rates reach their peak at an average temure of 8.8 years. Furthermore, firm income of agencies with at least two board inembers is positively related to diversity in top managers' ages and homogeneity in their firm tenure. That is, firm revenues are highest when top executives differ in age but are from the same tenure cohort. Growth rates of agencies with two or more board nembers are influenced by an interaction of average and spread in firm tenure. 
Table 6.3: The direct effect of leadership on fin performance.

\begin{tabular}{|c|c|c|c|}
\hline $\begin{array}{c}\text { DIRECT EFFECT: } \\
\text { LEADERSAIP - PERFORM }\end{array}$ & $\mathrm{NCE}$ & & \\
\hline Hypotheses & Prediction & \multicolumn{2}{|c|}{$\begin{array}{c}\text { Results } \\
\text { Alll agroncier }\end{array}$} \\
\hline $\begin{array}{l}\text { Hypothesis 5. 1: There is a concave relationship between the average age of } \\
\text { top execuines and advertising agency performance. } \\
\text { - average team age and firm income } \\
\text { - average team age and firm growth } \\
\text { - average team age and exit }\end{array}$ & $n$ & \multicolumn{2}{|c|}{$\begin{array}{l}\| n s \\
n 1 \mathrm{sis} \\
m 15\end{array}$} \\
\hline 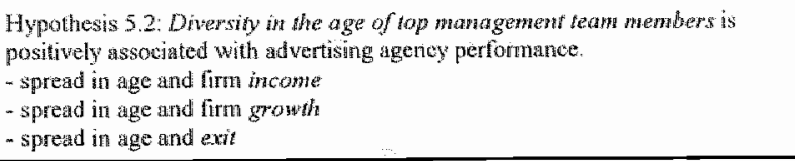 & $\begin{array}{l}4 \\
+ \\
+\end{array}$ & \multicolumn{2}{|c|}{$\begin{array}{l}+1 \\
n i s \\
n i s\end{array}$} \\
\hline 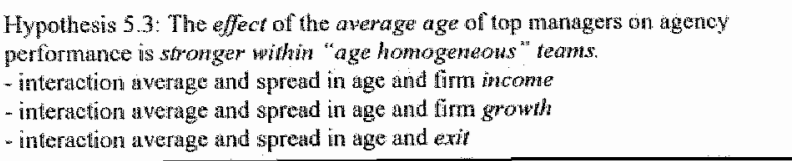 & + & \multicolumn{2}{|c|}{ ns } \\
\hline 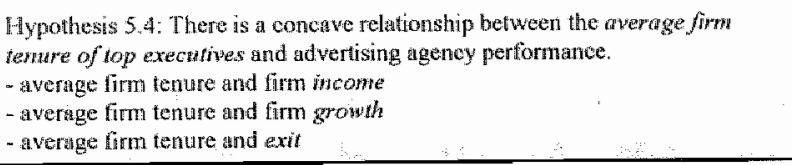 & $\begin{array}{l}n \\
n\end{array}$ & \multicolumn{2}{|c|}{$n$} \\
\hline 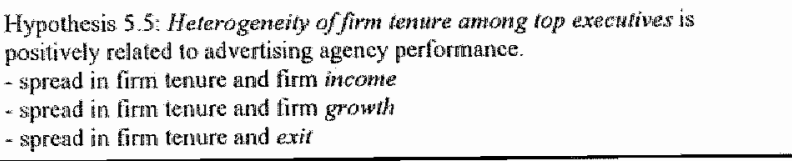 & $\begin{array}{l}+ \\
+ \\
-\end{array}$ & \multicolumn{2}{|c|}{$\begin{array}{l}- \\
\text { nis } \\
\text { ns }\end{array}$} \\
\hline 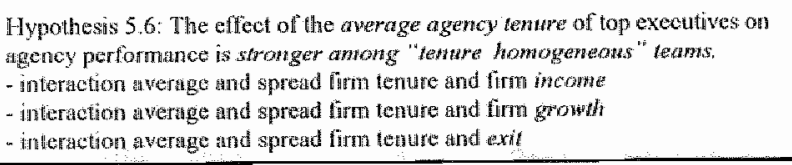 & $\begin{array}{l}+ \\
+ \\
+\end{array}$ & \multicolumn{2}{|c|}{$\begin{array}{c}4 ! \\
4\end{array}$} \\
\hline 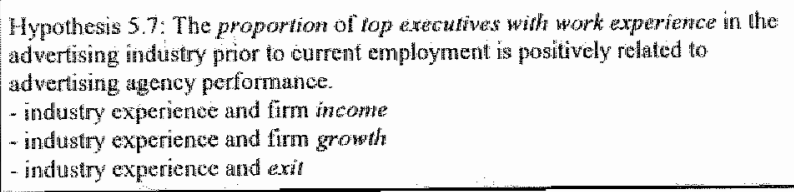 & + & \multicolumn{2}{|c|}{$\begin{array}{l}n s \\
n 15 \\
n s\end{array}$} \\
\hline 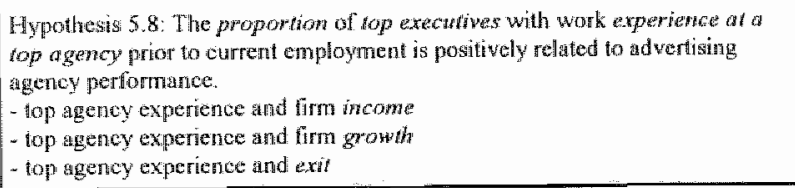 & + & \multicolumn{2}{|c|}{ - } \\
\hline 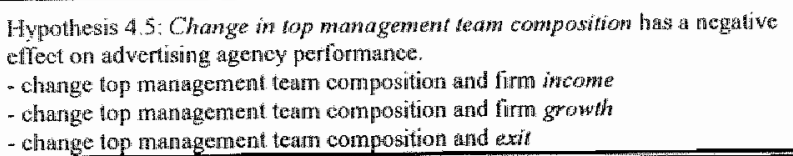 & $\therefore$ & $\begin{array}{c}\text { Small } \\
\text { agraciens: } \\
+ \\
+ \\
n\end{array}$ & 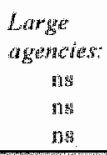 \\
\hline
\end{tabular}


The outcomes suggest that when average firm tenure among team members is longer than 12 years, spread in this characteristic positively affects growth rates. However, when the average firm tenure is shorter than 12 years, a homogeneous team in terms of tenure is best for growth. Apparently, the skills associated with short firm tenure, such as a propensity for risky decisions, are necessary for obtaining high growth rates. While in short tenured teams these skills are readily avalable, in long-tenured teams one or several short tenured managers are necessary to ensure these important competencies.

While the proportion of executives with industry experience per se is not related to firm performance; the proportion of managers with top agency experience is negatively connected to financial performance and survival chances. This outcome is explained in combination with the positive relationship between board size and performance. That is, in the years a firm performs poorly, board members without prior top agency experience are expelled from the board (and firm), perhaps because of bad performance, which implies an increase in top agency experience within the team of managers who remain with the firm. However, the executives who stay behind are not able to sufficiently turn around the declining spiral as their firm exited from the data set during the 1984-1994 period.

Finally, small agencies' financial results (both productivity and growth) increase subsequent to changes in the composition of the management team. Large agencies are unaffected by this type of change. Since mutations in the management team are positively correlated with the size of the board, it may be inferred that most changes refer to expansion of the board. Relating these results to the former findings means that in years of prosperity managers without top agency experience are admitted to the boards of small agencies.

\subsubsection{The mediating effect of organizational structure on performance}

Chapter 4 analyzes the effect of organizational change, and control variables, on firm performance, separately for small and large agencies. The results of this chapter are presented in Table 6.1-6.3. While the findings point out that an effect is sometimes significant for one group but not for the other, only once do the effects within the two subsets oppose each other (i.e., with respect to name change). Table 6.1 indicates that the impact of organizational structure is, in balance, equally strong for small and large agencies. Table 6.2 and 6.4 demonstrate that strategic positioning and change in strategic positioning have a stronger effect on small than large agencies" performance. The only leadership effect (see Table 6.3) that is separately examined among small and large firms, change in top management team composition, appears to have somewhat stronger consequences for small compared to large agencies' financial performance. 


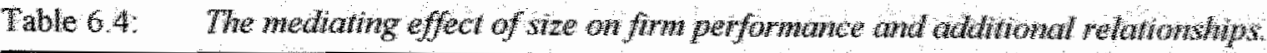

\begin{tabular}{|c|c|c|}
\hline \multicolumn{3}{|c|}{ MEDIATMG EFTET OF SWE ON PERTORMANCE } \\
\hline Hypotheses & Prediction & 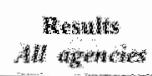 \\
\hline 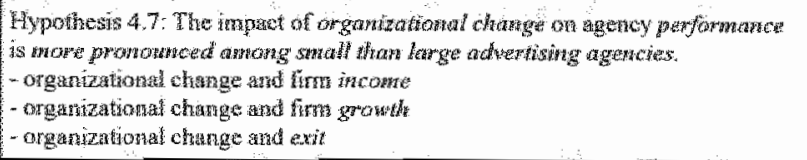 & : & $=$ \\
\hline \multicolumn{3}{|c|}{ STRUCTURE-STRUCTURE RELATIONSAIPS } \\
\hline 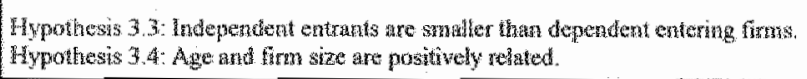 & $\dot{r}+$ & + \\
\hline \multicolumn{3}{|c|}{ PERFORMANCE - REFORMANCE RLLATIONSHIPS } \\
\hline $\begin{array}{l}\text { Hypothesis 3.11. Exit is negatively retated to firn growth. } \\
\text { Hypothesis 3. 22: Exit is negatively refated to productivity. }\end{array}$ & - & $\therefore$ \\
\hline
\end{tabular}

\subsubsection{Thdirect effects on performance}

Indirect efects of organizational and top management tean variables on fum success are not specifically examined in this book. However, the indrect effect of organzational stucture (size) on performance via strategy and organizatomal change has received some attention in Chapter 4 by txamining effects among small and large agencies separately. Differences between the two subsamples of agencies in terms of organizational structure and surategic positioning were detected. The differences are summarized by the presentation of separate descriptions of the set of small and large agencies.

Small advertising agencies are, on average, 14 years old. Five percent is (partly) owned by a large advertising firm and 68 percent is located in the Randstad. Their average growth rate over the years is around 7 percent; but large differences between the agencies and within agencies over the years exist. Almost 23 percent of the small firms exits from the data set before 1994. In terms of strategies, small advertising firms have a rather diverse client and media service portfolio, which they have slightly increased during the eleven years under study. Between 1984 and 1994, 35 percent of small firms experienced at least one change in ownership and 55 percent has had at least one mutation in the composition of the top management team. Changes in name or location occurred rarely; these events took place in 7 and 3 percent of small agencies, respectively.

Large advertising firms are, on average, 24 years old. Around 30 percent is (partly) owned by a large advertising firm and 76 percent is seated in the Randstad. The average growth rate of large agencies is 5 percent, but differences between the agencies are substantial. Almost 12 
percent of the set of large advertising firms exits before the end of the time period. Large agencies have rather diverse client and media service portfolios in which they carry through only small increases In most of the large firms ( 72 percent) at least one board mutation took place, while about half of them ( 52 percent) experienced at least one change in ownership. Most large fims refraned form changing their name and moving to another city: 18 percent of arge agencies transformed their names at least once and 4 percent moved to another city between 1984 and 1994

\subsection{The relationship between and reliability of the three performance measuries}

As becomes clear from Tables 6.1-6.3, (i) a limited number of yariables are simultaneously connected to the two financial performance indicators and (ii) a restricted number of variables are at the same time related to financial performance (one or both measures) and the probability of fallure. When these situations occur, the direction of the linkages are generally in the same direction. One exception with respect to the financial measures, although expected, pertains to the results with respect to firm size. Large firms are more productive than small agencies, but the latter have higher growth rates. An exception concerning financial performance and survival chances involves small agencies' board size. This result may be explained by the situation that during successful years agencies enlarge their boards while during poor years they decrease their boards. Howewer, over the entire time period in the study exiting agencies still had larger boards compared to surviving advertising firms.

Notwithstanding the significant outcomes of the studies of this thesis, the impact of the factors examined throughout the book on financial performance is not always as strong as expected, and the effects on survival chances are rarely significant. Apart from study-specific reasons, two general explanations were forwarded in Chapters 4 and 5 that probably each account partly for the insignificance of findings and the differences in the signs of the effects on financial performance and survival chances. First, the reliability of the performance measures may be questioned. Second, the severeness of and difference between the applied testing techniques may be responsible. In Chapter 2 it was argued that financial performance measures may be somewhat positively biased, underestimating potential linkages with independent factors. The effects on failure chances were suggested to be a bit underestimated due to the operationalization of failure as exit from the sample together with a lack of data for a number of bankrupt and dissoluted firms one or several years before these events actualiy took place. Since insufficient data exiters showed an identical performance pattern in the years before the exit event as bankrupt and dissoluted agencies (see Chapter 3), and because falling below a certain size threshold may also be considered a form of failure, the exit operationalization problem seems to be minor. The lack of data is probably more important, and may indeed have resulted in an underestimation of possible linkages. Since the analyses have produced only few 
contradicting results, there is no reason to doubt the basic reliability of the penformance measures, but there is reason to believe in an underestimation of the general tendencies of the findings. However, since we do not have information on the performance and characteristics of the exiting firms in the lacking years before the real event, one may, therefore, only suggest that this information would have rendered the results more significant.

Second, the impact on financial performance is analyzed with fixed-ffects estimates, which are very conservative tests of the hypotheses. Since the average number of years the firms are in the data set was about five years, the differences observed, especially as to the demographic make up of the management teams and client and service diversity levels, could not be expected to alter very much over the years, implying that the results of the fixed-effects analyses could not be very significant. Furthermore, since these analyses model only withirtfirm variation, differences between firms are not assessed. The logistic regression analyses over the agency means, used to examine survival chances, imply a loss of information as well. However, due to data limitations, survival analyses (e.g., event history analysis) that use all observations and take the time aspect into account could not be carried out

\subsection{General conclusions}

The studies of the direct and mediating effects of organizational structure and management capital variables on performance have produced many significant outcomes. On the basis of the findings, several conclusions and recommendations can be formulated that may be of interest to advertising fims' owners and top managers as well as to individuals planning to create an advertising agency. It is important that the suggestions formulated below are interpreted while taking into account at least four drawbacks. First, the findings pertain to the 1984 - 1994 period. In fact, recommendations may, therefore, always be rendered out of date. Moreover, the study did not investigate the development of the determinants of business success over the eleven-year period. Elaborating on such pattern dynamics is, thus, impossible with the present information. Second, the results are based on statistical analyses, which implies that they (and the recommendations) reflect averages, i.e., general tendencies in the market. Exceptions, therefore, may well occur, without however disconfirming the general tendencies. Of course, this also implies that following up the suggestions does not guarantee business success. Third, each empirical study is incomplete. That is, the results of the current study reflect the reality of the functioning of the Dutch advertising industry only partially. In combination with other factors, not examined in this thesis, the (importance of the) present findings may change. Fourth and finally, the studies involve different samples of advertising agencies. When the studies are based on the smaller subsamples, one must be careful with generalizing the results to the firms not included in these studies. Especially the subsample used in Chapter 5, on top management team composition, is rather small so that the findings may not be generalizable to 
other samples.

The findings giwe rise to twenty conclusions and suggestions:

1. Organizational aspects and management capital factors investigated in this thesis significantly affect the financial success and, to a lesser extent, the probability of survwal of Dutch adventising agencies: The importance of the aspects depends on the performance measure in question and on the size of the advertising firms.

2. In order to increase their survival chances, it is important for small advertising agencies to grow in terms of income, although a high growth rate is, in itself, no guarantee for survival.

3. Given the size of the firm, young advertising agencies are more productive and have a higher growth pace than their older counterparts.

4. Location in the Randstad provides better chances for high performance than location in other regions of the Netherlands, and decreases chances of failure.

5. Removal to another city by small agencies is generally followed by a low growth pace. (Partial) ownership by a larger advertising firm is beneficial for agencies' growth rate.

7. Changes in the ownership structure of an agency do not seriously affect firm results.

8. In financially successful years advertising agencies expand their boards with nonowner managers who have no previous experience at a top agency. During poor performance years, these executives are expelled from the board.

9. Mutations in the top management team of small firms are followed by an increase in financial performance. Large agencies" results are unaffected by such changes.

10. In terms of financial performance, advertising agencies perform best when the average firm tenure within the top management team is about 9 years.

11. Agencies with at least two board members achieve the highest income, given the size of the firm, when top managers differ strongly in age.

12. The average age of top managers has no direct impact on advertising firm performance.

13. Agencies with at least two board members obtain the highest firm revenues, given the size of the firm, when top executives belong to the same tenure cohort.

14. The highest firm growth rates of agencies with two or more board members are ackieved when the top management team consists of (i) managers of the same tenure cohort and an average firm tenure shorter than 12 years, or (ii) executives of different tenure cohorts and an average firm tenure longer than 12 years.

15. Small agencies" revenues augment with diversity in client portfolio.

16. Large agencies" income increases with specialization in media services.

17. Increases in media service diversity by small agencies are often followed by relatively low growth paces. 
18. Small advertising agencies that failed during the 1985-1994 period were characterized by a specialized media services offer:

19. Large advertising firms' growth rates decline subsequent to a name change.

20. Small agencies' growth paces increase after a name change

\subsection{Contribution to the literature}

This thesis contributes to the current state of the art in the organizational performance literature in several ways. First, the study has examined a set of factors affecting organizational performance in the Dutch advertising industry, ower an eleven-year time period, $1984-1994$. The Dutch advertising industry has not received much in-depth attention from managenent scholars yet. This thesis has contributed to a deeper understanding of the success factors prevailing in this industry. Second, the empirical studies address three levels of analyses: the industry, the organization and the top management team level Third, the effect of organization and management factors are examined on financial success as well as survival chances, an important distinction not always made in empirical research. Fourth, the mediating eflect of firm size on the organizational change - performance relationship is investigated Finally, each of the three empirical studies has a specific contribution to the literature in which it is embedded:

This study pertains to the Dutch advertising industry only. While some of the observed relationships seem to be industry specific and may apply to the same industry in other countries as well, they may be less generalizable to other industries (e.g., spread in firm tenure). Other connections reported in this market may hold in other industries as well. For instance, the findings on managerial succession have also been observed in other industries. Perhaps the results observed in these studies hold true in other professional service industries too, such as accountancy and consultancy, since these firms are also rather small with the attraction of customers being crucial. However, specific research in these industries is needed to confirm this conjecture.

\subsection{Future research}

This book has examined a number of important determinants of business success in the Dutch advertising industry. However, as said earlier, the picture of the determinants of business success is not complete. Hence, future research is needed to further unravel the complex combination of factors inside and outside the organization that determine success in the Dutch advertising industry. The data base on the Dutch advertising agencies is very rich, and this thesis has only used part of it. Some suggestions for future research are presented below.

This thesis has addressed a number, but not all, of the relationships in the framework presented in Figure 1.1. The analyses can be extended to the connections in figure 1 . I that 
have not been dealt with in this thesis. One of the connections not addressed in this book is the relationship between industry characteristics and firm performance. In this thesis, industry effects on performance of advertising agencies were controlled for by introducing year dummies in the analyses. However, as Chapters 2 and 3 have revealed, data are available on the annual levels of concentration, density, growth in advertising expenditures, and entry and exit rates. Future research may unrawel the relative importance of these market characteristics on the success of advertising firms

Future research may also concentrate on the connection between top management team composition and (change in) the firms" strategic profile. As yet, only the direct influence of top management team composition on advertising firm performance has been examined. However, as mentioned in Chapter 5, upper echelon theorists suggest that the impact of top managers on performance is above all indirect via the choices of strategies. This route can be explored in future studies. Top management team composition may be linked to the strategies that advertising firms pursue, as well as to the degree to which changes in organizational features are (successfully) carried through (see, e.g., Wiersema and Bantel, 1992; Boone, De Brabander and Van Witteloostuijn, 1996).

Top management team composition may, in future research, be related to industry average financial performance. Following Finkelstein and Hambrick (1990), it may be argued that if conservatism produces conservative decisions, this would imply that performance of firms headed by these conservative individuals are closer to industry averages than the performance of companies directed by more risk-prone managers. Advertising firm performance operationalized in terms of the absolute deviation from the industry average (Finkelstein and Hambrick, 1990), or as the variation in financial results, has not been examined in this thesis but should certainly be a concern of future research.

The current analyses may be extended by introducing fine-grained measures of some of the variables that are examined in this study by means of dummy variables: top management team mutations and changes in ownership, location and agency name. For example, with respect to location change, the direction (to or out of the Randstad) and the distance between the two locations may be included in future research.

As said, the data set allows for more in-depth analyses. Mutations in the top management teams can, for instance, be examined more profoundly. That is, the analyses can be extended not only to proportions or absolute numbers of mutations instead of the dummy variable applied in Chapter 4 , but the personal characteristics of the "leavers" and the "stayers" may be imvestigated as well. What are the features of managers who leave a firm and are attracted by a competing agency? Are the young and experienced the first to be attracted by competing agencies? Moreover, demographics of switching executives may be compared to characteristics of board members that stay behind or the composition of the board that admits the new 
member(s). In addition, the data set provides the opportunity to follow the career paths of top managers across the industry.

Additional top manager characteristics are available in the data set (in a raw data form), which, of course, can be used in future studies. Level of education, occupation. industry tenure, founder and work experience in another industry are the most important variables in this context. However, as was the case with the variables age, firm tenure and agency experience, the data are available for a large number of individuals, but not for a large number of teams. It is, thus, imperative to collect more information on these characteristics by other means than contemplating the industry year books. Contacting the agencies concerned seems to be the best method. If this would be achieved, not only could Chapter 5 be extended, with a larger sample and different analyses, but a substantial number of additional studies, such as the in-depth analysis proposed above, could be carried out while including these important team features

While the data set covers a period of eleven years, the chapters have used the longitudinality of the data set in some instances only. Chapters 2 and 3 include longitudinal aspects by describing concentration levels and top-ten rankings for each year (Chapter 2), examining the entry and exit dynamics over the whole period, and analyzing the pattern of post-entry and preexit performance of agencies (Chapter 3). Chapters 4 and 5 estimate fixed-effect models. Future studies could exploit the longitudinality of the sample more fully. For instance, similar post-entry and pre-exit analyses could be undertaken with respect to the competitive strategy, organizational change and top management team characteristic variables. This type of in-depth analysis of entrants and exiters can be carried out with the available data. With respect to survival chances, Chapters 4 and 5 have applied logistic regression analyses using agency means. Enlarging the data set would allow for survival analyses that use all observations and take the time aspect into account (e.g., event history analysis). In addition, in order to assess the effect of organizational change and management capital on financial performance of advertising agencies, Chapters 4 and 5 have focused on within-firm variation. Future analyses concerning the financial performance of advertising agencies could concentrate on betweenfirm variation.

Finally, only in Chapter 3, the specificity of merging firms was highlighted. The pre-exit performance of merging agencies appeared to differ substantially from the performance in the years preceding disbanding of other categories of exiters. For that reason, in the remaining chapters the mergers were excluded from the set of failing firms. However, their specificity has not been examined in more detail in this thesis. An in-depth analysis of mergers and acquisitions in terms of their antecedents and consequences could unravel the extent to which these events can be foreseen, and to which party it is beneficial in the short and long run. 


\section{APPENDIX}

\section{MATCHED PAIRS OF ADVERTISING AGENCIES}

\section{Matched pairs of entrants: faillers and survivors}

- Enfrants sample in 1985

\begin{tabular}{|c|c|c|c|c|c|c|}
\hline Agency & Stanf & Sales & Foundinge & Exit/ & Year & Ownership \\
\hline 1 & stilo & & year & survival & & large firm \\
\hline Equppe & 10 & 1.46 & 983 & Bankruptcy & 1993 & 0 \\
\hline $\begin{array}{l}\text { Le Bureat } \\
2\end{array}$ & 9 & 1.62 & 1984 & Survivor & & -9 \\
\hline van $0 \mathrm{sech}$ & 6 & 1.01 & 1981 & Acquisition & 1993 & 0 \\
\hline $\mathrm{VWIH}$ & 5 & 149 & 1985 & Surwivor & & 0 \\
\hline 3 & & & & & & \\
\hline Reollanetean & 4 & .37 & 1981 & Instfir values & 1994 & -9 \\
\hline Apropos & 4 & 59 & 1981 & Survivot & & 0 \\
\hline 4 & & & & & & \\
\hline Curat Reklarme & 10 & 91 & 1970 & Instiff values & 1994 & 0 \\
\hline Tlat & 9 & .95 & 1974 & Survivor & & -9 \\
\hline - Etrtants sam & Le in 1986 & & & & & \\
\hline Joint Venture: & 5 & 40 & 1978 & Bankruptcy & 1993 & 0 \\
\hline$B S E$ & 5 & 57 & 1982 & Survivot & & 0 \\
\hline 6 & & & & & & \\
\hline Market Team & 5 & 45 & 1979 & Institl values & 1992 & 0 \\
\hline $\begin{array}{l}\text { Initigentem } \\
7\end{array}$ & 4 & 73 & $\$ 981$ & Struivor & & -9 \\
\hline Carela & 7 & 1.07 & 1984 & Banknuptcy & 1994 & -9 \\
\hline Reclano Heller & que 6 & 1.20 & $\$ 971$ & Survivot & & -9 \\
\hline - Emtrants sam & te in 1987 & & & & & \\
\hline Buswness & 15 & 2.11 & 1984 & Bankruptcy & 1992 & 0 \\
\hline MORE & 16 & 2.72 & 1986 & Survivor & & 0 \\
\hline - Eutrants sam & te in 1988 & & & & & \\
\hline Houssun & 3 & 30 & 1986 & Insug values & 1994 & 0 \\
\hline Theo vid Mars & 3 & 20 & 1986 & Survivot & & 0 \\
\hline $\begin{array}{l}\text { - Entronts sam } \\
\text { (1) }\end{array}$ & lein 1989 & & & & & \\
\hline VVSEW & 9 & 89 & 1987 & lostff values & 1994 & -9 \\
\hline "otsunktref" & 9 & 1.58 & 1983 & Survivot & & 0 \\
\hline
\end{tabular}

Matched pairs of incumbents: bankruptcies and survivors

\begin{tabular}{|c|c|c|c|c|c|c|}
\hline Agency & $\begin{array}{l}\text { Staft } \\
\text { sine }\end{array}$ & Sules & $\begin{array}{l}\text { Wounding } \\
\text { year }\end{array}$ & $\begin{array}{l}\text { Exit/ } \\
\text { survival }\end{array}$ & Year & $\begin{array}{l}\text { Owmership } \\
\text { large furm }\end{array}$ \\
\hline 1Hil & 9 & 1.28 & 1911 & Bankruptcy & 1992 & 0 \\
\hline Wuil & 9 & 1.06 & 1955 & Sumivo" & & 0 \\
\hline 2 & & & & & & \\
\hline KVIICOK & 30 & 6.08 & $\$ 944$ & Bankruptcy & 1993 & -9 \\
\hline 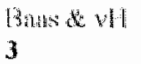 & 30 & 4.58 & 1961 & Survivot & & 0 \\
\hline T.mo: & 7 & 1.11 & 1975 & Bankruptcy & 1993 & 0 \\
\hline Kostinut & 7 & 98 & 1976 & Survivot & & 0 \\
\hline
\end{tabular}




\begin{tabular}{|c|c|c|c|c|c|c|}
\hline $\begin{array}{l}\text { Agency } \\
4\end{array}$ & $\begin{array}{l}\text { Staff } \\
\text { süze }\end{array}$ & Sales & $\begin{array}{l}\text { Founding } \\
\text { year }\end{array}$ & $\begin{array}{l}\text { Enit } \\
\text { survival }\end{array}$ & Vear & $\begin{array}{l}\text { Onnership } \\
\text { large firm }\end{array}$ \\
\hline OKS & 13 & 1.74 & 1971 & Bunkruptey & 1993 & 0 \\
\hline $\begin{array}{l}\text { Normad } \\
5\end{array}$ & 12 & 2.17 & 1972 & Survivor & & 0 \\
\hline Opzeeland & 16 & 2.06 & 1913 & Bardkruptoy & 1994 & 0 \\
\hline Doits & 18 & 1.68 & 1910 & Survivor & & 0 \\
\hline Schothorst & 7 & 1.49 & 1982 & Barkruptey & 1992 & 0 \\
\hline $\begin{array}{l}\text { Leme, v. Doorn } \\
7\end{array}$ & 6 & 1.31 & 1981 & Sumpivor & & 0 \\
\hline Vonk & 6 & .53 & 1969 & Bankruptcy & 1993 & 0 \\
\hline $\begin{array}{l}\text { Grafito } \\
8\end{array}$ & 6 & .45 & 1970 & Snurvivor & & 0 \\
\hline Makketwinning & 26 & 4.29 & 1971 & Dissolution & 1993 & 1 \\
\hline Grey & 30 & 5.48 & 1975 & Strwiwor & & 1 \\
\hline
\end{tabular}

\section{Matched pairs of incumbents: 'insufficient data exiters' and survivors}

\begin{tabular}{|c|c|c|c|c|c|c|}
\hline $\begin{array}{l}\text { Agency } \\
t\end{array}$ & $\begin{array}{l}\text { Staff } \\
\text { size }\end{array}$ & Sales & $\begin{array}{l}\text { Founding: } \\
\text { year }\end{array}$ & $\begin{array}{l}\text { Exit/ } \\
\text { survival }\end{array}$ & Yesar" & $\begin{array}{l}\text { Ownership } \\
\text { large firm }\end{array}$ \\
\hline Advice & 6 & 1.14 & 1975 & Insulficiant values & 1992 & 0 \\
\hline Admix & 6 & 1.08 & 1974 & Sthrvivor & & 0 \\
\hline 2 & & $\therefore$ & - & & & \\
\hline Applia & 8 & 1.41 & 1981 & Insufficient values & 1993 & 0 \\
\hline Roklaring & 9 & 1.17 & 1982 & Survivor & & -9 \\
\hline \multicolumn{7}{|l|}{3} \\
\hline Bownan & 13 & 2.68 & 1945 & Insufticient valnes & 1994 & 0 \\
\hline DZM & 16 & 1.96 & .1945 & Statwivor & & 0 \\
\hline \multicolumn{7}{|l|}{4} \\
\hline $\mathrm{DSO}$ & 7 & .80 & 1978 & Insufficient values & 1992 & 0 \\
\hline Kooijman & 7 & .92 & 1978 & Survivor & & 0 \\
\hline \multicolumn{7}{|l|}{5} \\
\hline HWK & 6 & .87 & 1979 & Insuffictent values & 1993 & 0 \\
\hline$H z$ & 6 & 92 & 1979 & Survivo" & & 0 \\
\hline \multicolumn{7}{|l|}{6} \\
\hline USSRoming & 4 & 61 & 1964 & Insinflicient values & 1992 & 0 \\
\hline Akron & 7 & 60 & 1967 & Sthrivol & & .9 \\
\hline \multicolumn{7}{|l|}{7} \\
\hline Kulateijor & 3 & 31 & 1979 & hasulfoctent valuos & 1991 & 0 \\
\hline Venhow? & 3 & 1.21 & 1979 & Survigon & & 0 \\
\hline \multicolumn{7}{|l|}{8} \\
\hline $\mathrm{KMP}$ & 6 & 69 & 1976 & Instufficient values & 1993 & 0 \\
\hline Wubbe & 6 & .77 & 1976 & Survivor & & 0 \\
\hline \multicolumn{7}{|l|}{9} \\
\hline Muller \& Man 3 & 3 & 30 & 1966 & Insulffucienal walues & 1992 & 0 \\
\hline Gration & 6 & .45 & 1970 & Survivor & & 0 \\
\hline \multicolumn{7}{|l|}{ 目0 } \\
\hline Pieterman & 4 & .59 & 1980 & Insufficingt values & 1991 & 0 \\
\hline De Bruin Burgers & 4 & 69 & 1978 & Suluivot & & 0 \\
\hline \multicolumn{7}{|l|}{11} \\
\hline Ruing \& Hohmeste & Ler 4 & .58 & 1983 & Insulfucient values & 1993 & () \\
\hline De Gitad \& Pove & 5 & 78 & 1983 & Survinor & & 0 \\
\hline \multicolumn{7}{|l|}{12} \\
\hline De Vlieger & 4 & .25 & 1980 & Insulficient vallues & 1993 & 0 \\
\hline Nijboner & 4 & 1.31 & 1982 & Survivor & & 0 \\
\hline
\end{tabular}


Matched pairs of incumbents: mergers/ acquisitions and survivors

\begin{tabular}{|c|c|c|c|c|c|c|}
\hline $\begin{array}{l}\text { Agency } \\
1\end{array}$ & $\begin{array}{l}\text { Staff } \\
\text { stze }\end{array}$ & Solles & $\begin{array}{l}\text { Founding } \\
\text { year }\end{array}$ & $\begin{array}{l}\text { Exiu } \\
\text { garvival }\end{array}$ & Year & Ownership \\
\hline $\mathrm{ACH}$ & 6 & 1.15 & 1974 & Merger/Aci & 1992 & 0 \\
\hline $\begin{array}{l}\text { Aumix } \\
2\end{array}$ & 6 & 1.08 & 1974 & Survivor & & 0 \\
\hline Bratinter & 7 & 1.08 & 1974 & $M A$ & 1992 & 0 \\
\hline $\begin{array}{l}\text { Inlour } \\
3\end{array}$ & 8 & .94 & 1974 & Surwiwor & & 0 \\
\hline Adpont & 7 & 1.07 & 1959 & $M A$ & 1994 & 0 \\
\hline $\begin{array}{l}\text { Arti Print } \\
4\end{array}$ & 7 & .37 & 1957 & Survivor & & -9 \\
\hline Goudeker & 42 & 6.40 & 1976 & $M / A$ & 1993 & 0 \\
\hline $\begin{array}{l}\text { Belinfunte } \\
5\end{array}$ & 37 & 4.55 & 1978 & Survivor & & 0 \\
\hline Prad & 64 & 13.78 & 1946 & M/A & 1991 & 1 \\
\hline $\begin{array}{l}\text { Benton \& Bowles } \\
6\end{array}$ & 55 & 870 & $195 \rrbracket$ & Survivor & & 1 \\
\hline Push & 12 & 2.20 & 1981 & A & 1991 & 0 \\
\hline $\begin{array}{l}\text { Hint } \\
7\end{array}$ & 10 & 1.21 & 1981 & Survivor & & 0 \\
\hline Westerad & 5 & .59 & 1969 & $M / A$ & 1991 & 0 \\
\hline $\begin{array}{l}\text { Grafite } \\
8\end{array}$ & 6 & .45 & 1970 & Starviwor & & 0 \\
\hline $\begin{array}{l}\text { NPO Inivas } \\
\text { Salchi \& Suatchi }\end{array}$ & $\begin{array}{c}68 \\
75\end{array}$ & $\begin{array}{l}12.13 \\
9.84\end{array}$ & $\begin{array}{l}1944 \\
1950\end{array}$ & $\begin{array}{l}\text { M/A } \\
\text { Surviwor }\end{array}$ & 1993 & $\begin{array}{l}1 \\
1\end{array}$ \\
\hline
\end{tabular}

\section{Descriptives of matched pairs}

\begin{tabular}{|c|c|c|c|c|c|}
\hline \multirow{2}{*}{\multicolumn{6}{|c|}{$\overline{\text { ENTRANTS }}$}} \\
\hline & & & & & \\
\hline \multirow[t]{2}{*}{ Nr at employees } & Failers & 7.40 & 3.63 & 3 & 15 \\
\hline & Survivers & 7.00 & 3.89 & 3 & 16 \\
\hline \multirow[t]{2}{*}{ Sules } & Faillers & 90 & .57 & .30 & 2.11 \\
\hline & Survivoris & 1.16 & .73 & .20 & 2.72 \\
\hline \multirow[t]{2}{*}{ Fouthding year } & Fuilers & 1981.30 & 4.90 & 1970 & 1987 \\
\hline & Survikgrs & 198130 & 5.03 & 1971 & 1986 \\
\hline \multicolumn{6}{|l|}{ INCUMBENTS } \\
\hline \multicolumn{6}{|c|}{ Bankrupd/ dissoluted agencies and survivors } \\
\hline \multirow[t]{2}{*}{ No ufemplowees } & Exiters & 14.25 & 9.19 & 6 & 30 \\
\hline & Survivors & 14.75 & 10.21 & 6 & 30 \\
\hline \multirow[t]{2}{*}{ Sablow } & Exiters & 232 & 1.89 & .53 & 6.08 \\
\hline & Surviwars: & 2.21 & 183 & .45 & 5.48 \\
\hline \multirow[t]{2}{*}{ Fusursing year } & Exiters: & 1954.50 & 28.43 & 1911 & 1982 \\
\hline & Suvvivors & 196250 & 22.81 & 1910 & 1981 \\
\hline
\end{tabular}




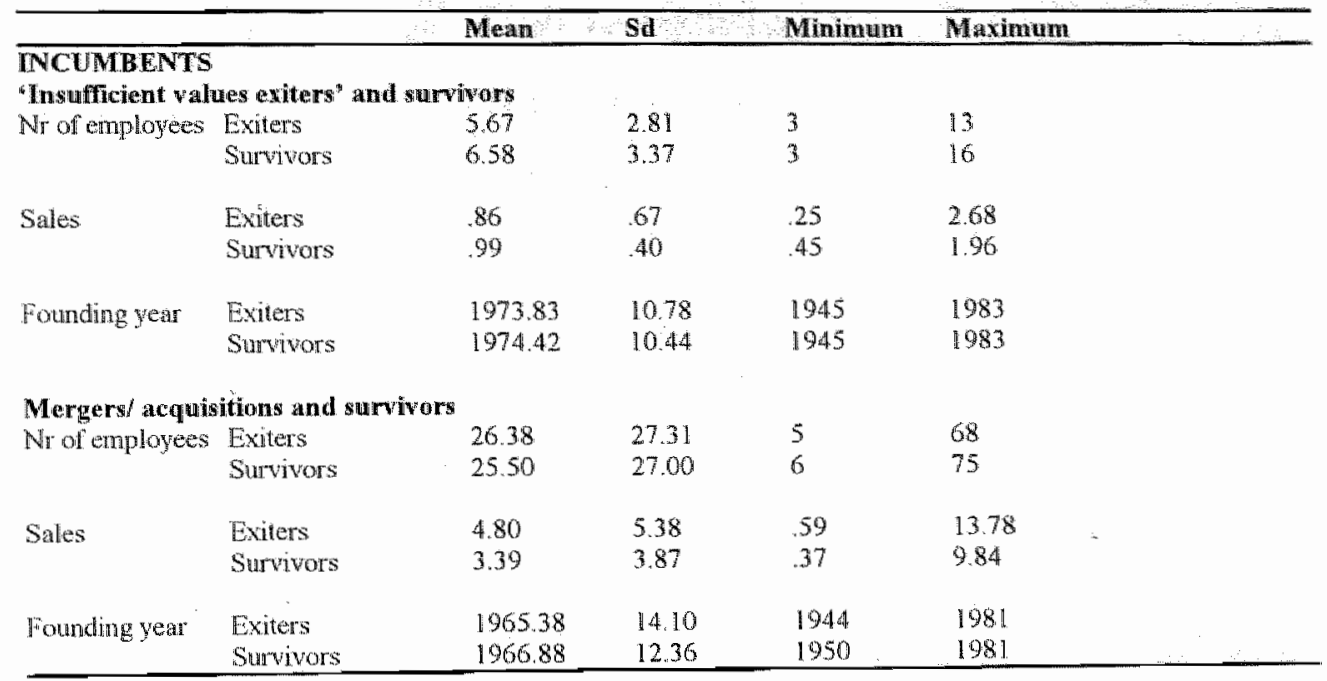




\section{REFERENCES}

Adformatie (1990). Groei Top 10 Bureaugroepen Vlakt af naar 6,6 pet. Adformatie, 4, January 25

Adformatie (1994). Adformatie/Scan-jaaroverzicht 1993. Adformatie, 8, February 24

Adformatie Bureatu Bijlage (1984 - 1995). Aphen aan de Rijn: Samson BedrijfsInformatie bv.

Alsem, K.J. (1991). Concurrentie-analyse in de Marketing. Theorie, Technieken en Toepasm singen. Leiden: Stenfert Kroese Uitgevers.

Alsem, K.I. and Leeflang, P.S.H. (1994). Predicting Advertising Expenditures Using Intention Surveys. International Jownal of Forecasting. 10, 327-337.

Amburgey, T.L., Kelly, D and Barnett, W.P. (1993). Resetting the Clock: The Dynamics of Organizational Change and Failure. Administrative Science Quarterly, 38, 51-73

Arrow, K. (1973). Higher Education as a Filter. Joumal of Public Economics, 2, 193-216,

Audretsch, D.B. (1991). New-Firm Survival and the Technological Regime. The Review of Economics and Statistics, 441.450

Audretsch, D. B. (1994). Business Survival and the Decision to Exit. Joumal of Ecomomics and Business, 1, 125-137.

Audretsch, D.B. ( 1995$)$. Innowation, Growth and Survival. International Joumal of Industrial Orgonization, 13,441-458.

Audretsch, D.B. and Mahmood, T. (1994). Firm Selection and Industry Evolution: The Post-Entry Performance of New Firms. Joumal of Evohutionary Economics, 4, 243 260

Audretsch, D.B and Mahmood, T. (1995). New Firm Survival New Results Using a Hazard Function. The Review of Economics and Statistics, 97-103

Baldwin, J R and Gorecki, P.K. (1991). Firm Entry and Exit in the Canadian Manufacturing Sector, 1970-1982. Canadian Joumal of Economics, 2, 300-323.

Baldwin, J.R and Rafiquzzaman, M. (1995). Selection versus Evolutionary Adaptation: Learning and Postentry Performance. International Journal of Industrial Organizatim on, $13,501-522$.

Barnet, W.P. and Carrol, G.R. (1987). Competition and Mutualism among Early Telephone Companies. Adwinishatwe Science Onarterly, 32, 400-421.

Bantel, K.A and Jackson, S.E. (1989). Top Management and Inmovations in Banking: Does the Composition of the Top Team Make a Difference? Strategic Management Jow nal, 10, 107.124

Bates, T. (1990). Entrepreneurial Human Capital Inputs and Small. Business Longevity. Revin of Lcomomicx and Statistics, 72, 551-559.

Baum, J.A.C. (1996). Organizational Ecology. In S.R. Clegg, C. Hardy, and W. Nord (eds), Hawdbook of Orgamization Stwdies, London: Sage.

Beatty, R and Zajac, E (1987). CEO Change and Firm Performance in Large Corporations. Succession Effects and Manager Effects. Strategic Management Jowral, 8, 305-317.

Becker, G.S (1964). Human Capial. A Theoretical and Empirical Analysis, with Special Keference to Education. New York. NY: Columbia University Press.

Berg, 1. (1970). Edhoation and Jobs: The Great Training Lobbery New York, NY: Praeger

Blau, P.M. (1977). Mnequality and Helerogeneity: A Primitive Theory of Social Structure New York: Free Press. 
Blau, J. (1984). Apchirects and Fimm. Cambridge, MA. MIT Press.

Blauwe Bugamor (1984-1986). Almere-Haven: Bugamor.

Blauwe Bureaugids (1987-1993). Almere-Stad: NieuwsTribune.

Blauwe Bureau Tribune (1994). Almere-Stad: Nieuws Tribune.

Bochove, J. (1994).Bureaus Scoren Slecht op de Belangrijkste Succestactoren. Niewws Tribune, 21 mei, 32-36.

Boeker, W. (1989). Strategic Change: The Effects of Founding and History. Acodemy of Management Jowmal, 32, 489-515.

Boone, C., De Brabander, B. and Witteloostuijn, wan A. (1996). CEO Locus of Control and Small Firm Performance: An Integrative Framework and Empirical Test Jownal of Mamagement Studies, 33, 5, 667-699.

Boone, C, Olfen, van W., and Witteloostuijn, van A. (1997). Psychological Team Make-up as a Determinant of Economic Firm Performance. An Experimental Study. Joumal of Economic Psychology. Forthcoming.

Boone, C and Witteloostuijn, van A. (1995). Toward a Game Theory of Organizational Ecology. The Case of Owner Flexibility and Management Inertia. Reseowh Momorandum. Maastricht: MANOR/ Faculty of Economics and Business Administration.

Boone, C. and Van Witteloostuijn, A (1996). Industry Competition and Firm Human Capital. Small Business Economics, 8, 1-18.

Brüderl, J., Preisendörfer, P. And Zeigler, R. (1992). Survival Chances of Newly founded Business Organizations. American Sociological Rewiew, 57, 227-242.

Burke, D. and Light, L. L. (1981). Memory and Aging: The Role of Retrieving Processes. Psychological Bulletin, 90, 513-546.

Cable, J. and Schwalbach, J. (1991). International Comparisons of Entry and Exit. In Geroski, P. and Schwalbach, J. (eds), Entry and Market Contestability: An imernational Comparison, Oxford: Basil Blackwell.

Cagley, IW. (1986). A Comparison of Advertising Agency Selection Factors: Advertiser and Agency Perceptions. Jowrinal of Adverhising Rexearch, June/July, 39-44

Cagley, J.W. and Roberts, C.R. (1984). Criteria for Advertising Agency Selection: An Objective Appraisal. Jownal of Advertising Research, 24, 27-31

Carlsson, G and Karlsson, K. (1970). Age, Cohorts, and the Generation of Generations. Americon Sochological Review, 35, 710-718.

Carroll. G.R. (1984). Dynamics of Publisher Succession in Newspaper Organizations. Adwimistrative Science Quarterly, 29, 303-329

Carroll, G.R. and Huo, Y.P. (1986). Organizational Task and Institutional Environments in Evolutionary Perspective: Findings from the Local Newspaper Industry. American Jomrnal of Sociology, 91, 838-873.

Chown, S.M. (1960). The Wesley Rigidity Inventory: A Factor-analysis Approach. .own of Abnornal and Social Psychology, 61, 491-494.

Centraal Bureau voor de Statistiek (1996). Onder de Loep (jenomen: Reklane-en Advertevwebureaws. Heerlen. The Netherlands: CBS.

Coffee, JC. (1988). Shareholders versus Managers: The Strain in the Corporate Web. In Coffee, J.C., Lowenstein, L and Rose-Ackerman, S. (eds.). Kmighs, Ravidersin cind Targets: 77-134. New York: Oxford University Press.

Cohen, R. (1973). Patrems of Personality. Judgement. New York: Academic Press

Commission of the European Community (1994). Pamorama of ECIrdartries 1993

CSO (1994). Burcan Chient Satisfaction Onderzoek. Het Dozijn Uitgeefprojecten. 
Cummings, A., Zhou, J, and Oldham, G.R. (1993). Demographic Differences and Exployce Work Oucomes: Effects on Muliple Comparison Groups. Paper presented at the annuall meeting of the Academy of Management, Atlanta, GA.

Cyert, RM. and March, J.G. (1963). A Behavioral Theory of the Firm. Englewood Cliffs, Nill Prentice Hall.

Daft, R. (1983): Organization Theory and Design. St. Paul, MN: West Publishng.

Delacroix J and Swaminathan, A. (1991). Cosmetic, Speculative, and Adaptive Organizational Change in the Wine Industry: A Longitudinal Study. Administrative Sicience Quarterly; $36,631-661$

DiMaggio, P.J. and Powell, W. W. (1983). The Iron Cage Revisited: Institutional Isomorphism and Collective Rationality in Organizational Fields. American Saciological Review $48,147-160$.

Doms, M, Dunne, T. and Roberts, M.J. (1995). The Role of Technology Use in the Survival and Growth of Manufacturing Plants. International Journal of Industrial Organization, $13,523-542$.

Dunne, P. and Hughes, A. (1994). Age, Size, Growth and Survival: UK Companies in the 1980s. The ,lownal of Industrial Economics, 2, 115-140.

Dunne, T., Roberts, M.J. and Samuelson, L. (1988). Patterns of Firm Entry and Exit in U.S Manufacturing Industries. RAND Journal of Economics, 4, 495-515.

Dunne, T., Roberts, MI. and Samuelson, L. (1989a). The Growth and Failure of U.S Manufacturing Plants. The Quarterly.Journal of Economics, 671-698.

Dunne, "T, Roberts, M.J. and Samuelson, L. (1989b). Firm Entry and Postentry Performance in the U.S. Chemical Industries. Journal of Law and Economics, 32, 233-271.

Eisenhardt, K.M \& Bird Schoonhoven, C. (1990). Organizational Growth: Linking Founding Team, Strategy, Environment and Growth among U.S. Semiconductor Ventures, 1978-1988. Admimistrative Science Quarterly, 35, 504-529.

Enderwick, P. (1992). The Scale and Scope of Service Sector Multinationals. In: Buckley, P.J. and Casson . M. (eds), Multinational Enterprises in the World Economy. Worcester: Billing and Sons, 134-152.

Ethier, W. and Horm, H (1991). Services in international Trade. In: Helpman, E. And Razin, A. (eds), Inemational Trade and Thade Policy. Cambridge, MA: The MIT Press.

Evans, D.S. (1987). The Relationship Between Firm Growth, Size, and Age: Estimates for I00 Manufacturing Industries. The Jourral of Industrial Economics, 4, 567-581.

FHV/BBDO. (1983). The Selection Process of Advertising Agencies and Implications for a New-Business Policy. Amsterdam: Club of 13

Filley, A.C., House, R.J. and Kerr, S. (1976), Managerial Process and and Organizational Behovior, Glenview, lL: Scott Foresman.

Finkelstein, S. (1988). Managerial Orientations and Organizational Outcomes: The Moderating Roles of Managerial Discretion and Power. Unpublished Ph.D. dissertation, Columbia University.

Finkelstein, S and Hambrick, D.C. (1990). Top-Management-Team Tenure and Organizational Outcomes: The Moderating Role of Managerial Discretion. Administrative Science Quarterly, 35, 484-503.

Geroski, P.A. (1991). Some Data-Driven Reflections on the Entry Process. In: Geroski, P. and Schwalbach, J. (eds), Enry and Market Contestability: An international Compariwon, Oxford: Basil Blackwell.

Geroski, P.A. (1995). What Do We Know About Entry? International Journal of Industrial Organization, 13,42】-440 
Gladsten, D. (1984). A Model of Task Group Effectiveness. Administratwe Scrence Ouarterby, 29,499-517.

Gladstem Ancona, D. and Caldwell, D.F. (1992). Demography and Design Predictors of New Product Team Performance. Orgamzation Science, 3, 321-342

Goodman, P.S, Ravlin, E and Schminke, M. (1987). Understanding Groups In Organizations. In: L.L. Cummings and B.M Staws (eds), Research in Orgemizaronal Behawor, 9. 121-174. Greenwich CT: JAI Press.

Grusky, O. (1961). Corporate Size, Bureaucratization, and Managerial Succession. American "Jownal of Sociology, 67, 261-269

Hage, J. and Dewar, R. (1973). Elite Values versus Organizational Structure in Predicting Innovation. Administrative Science Qwarterly, 18, 279-290

Haleblian, J. and Finkelstein, S. (1991). The Effects of Top Management Team Size and CEO Dominance on Performance in Turbulent and Stable Environments. Papey presented at the Academy of Management Meeting, Mami.

Hall, B.H. (1987). The Relationship Between Firm Size and Firm Growth in the US Manu. facturing Sector. The Jomrnal of Industrial Economics, 4, 583-605.

Hambrick, D.C and D'Aveni, A. (1988). Large Corporate Failures as Downward Spirals. Administrative Science Quarterly, 33, 1-23.

Hambrick, D.C. and D'Aveni, R.A. (1992). Top Team Deterioration as Part of the Downward Spiral of Large Corporate Bankruptcies. Managemen Science, 38, 1445-1466.

Hambrick, D.C. and Mason, P.A. (1984). Upper Echelons: The Organization as a Reflection of its Top Managers. Academy of Managemen Review, 9, 193-206.

Hannan, M.T. and Freeman, J. (1977). The Population Ecology of Organizations. American Joumal of Sociology, 82, 5, 929-963.

Hannan, M.T. and Freeman, J. (1984). Structural Inertia and Organizational Change American Sociological Review, 49, 149-164.

Hannan, M.T, and Freeman, J. (1989). Organizational Ecology. Cambridge, MA: Harvard University Press.

Haveman, H.A. (1992). Between a Rock and a Hard Place: Organizational Change and Performance under Conditions of Fundamental Environmental Transformation. Admimistrative Science Quarterly, 37, 48-75.

Haveman, H.A. (1993a). Ghosts of Managers Past: Managerial Succession and Organizational Mortality. Academy of Management Joumal, 36, 4, 864-881.

Haveman, HA. (1993b). Organizational Size and Change: Diversification in the Savings and Loan Industry after Deregulation. Administrative Science Qwarterly, 38, 20-50

Holzer, H. (1993). Muli-City Study of Urban Inequality. Unpublished manuscript, Michigan State University.

Janis, I.L. (1972). Victims of Groupthink, Boston: Houghton Mifflin.

Johnson, G. and Scholes, K. (1993). Exploring Corporate Strategy: Text and Cases. New York: Prentice Hall.

Joskow, A.S., Werden, G.J. and Johnson, R.L. (1994). Entry, Exit, and Performance in Airline Markets. International Jomnal of Industrial Organization, 12, 457-471.

Jovanovic, B. (1982). Selection and the Evolution of Industry. Ecomometrica, 50, 649-670.

Katz, R. (1982). The Effects of Group Longevity on Project Communication and Performance. Administrative Science Quarterly, 27, 81-104.

Kelly, D. and Amburgey, T.L. (1991). Organizational Inertia and Momentum: A Dynamic Model of Strategic Change. Academy of Managemen Jow mal, 34, 591-612. 
Lawrence, B.S. (1988). New Wrinkles in the Theory of Age: Demography, Norms, and Performance Ratings. Academy of Management Journal, 31, 309-337.

Lawrence, P.R and Lorsch, J.W. (1967). Organization and Exvironment. Boston: Graduate School of Business Administration, Harvard University:

Levinthal, D. and March, J.G. (1984). A Model of Adaptive Organizational Search. Journal of Economic Behawhow and Organization, $2,307-333$.

Lieberson, $\mathrm{S}$. and O'Connon, J (1972). Leadership and Organizational Performance: A Study of Large Corporations. Anerican Sociological Review, 37, 117-130.

Liu, L. (1993). Entry-Exit, Learning, and Productivity Change. Evidence from Chile. Journal of Developmen Economics, 42, $217-242$.

Maijoor, S, Buijink, W, Van Witteloostuijn, A and Zinken, M. (1995). Long-Term Concentration in the Dutch Audit Market: The Use of Auditor Association Membership Lists in Historical Research, Abacus, 31, 152-177

Maister, D.H. (1993). Managing the Professional Service Firm. New York: The Free Press. March, J.G. and Simon, H.A. (1958). Organizations. New York: Wiley.

Mata, J. (1994). Fim Growth During Jufancy. Small Business Economics, 6, 27-39.

Mata, J. and Portugal, P. (1994). Life Duration of New Firms. The Journal of Industrial Economics, $3,227-245$.

Mata, J., Portugal, P. and Guimarães, P. (1995). The Survival of New Plants: Start-up Conditions and Post-entry Evolution. International Jownal of Industrial Organization, $13,459-482$.

Michell, P.C.N. (1988). Point of View: Advertising Account Loyalty. Jotumal of Advertising Research, December 1987/January 1.988, 61-67.

Miles, R.E. and Snow C.C. (1978). Organizational Strategy, Sirzchure, and Process. New York: McGraw-Hill.

Mills, D. (1992). Major Agency Profit League. Campaign, September 18.

Miller, D. (1991). Stale in the Saddle: CEO Tenure and the Match Between Organization and Environment Managemew Science, 37, 34-52.

Miller, D. and Chen, M. (1994). Sources and Consequences of Competitive Inertia: A Study of the U.S. Airline Industry. Administrative Science Qrarterly, 39, 1-23.

Miller, D. and Toulouse, J.M. (1986). Strategy, Structure, CEO Personality and Performan* ce in Small Firms. Americam Joumal of Small Business, 10, 47-62.

Milliken, F.J and Martiris, L.L. (1996). Searching for Common Threads. Understanding the Multiple Effects of Diversity in Organizational Groups. Acadewy of Management Review, $21,402-433$

Mincer, J. (1974). Schooling, Experience, and Earnings. New York: National Bureau of Economic Research, Columbia University Press.

Murray, A.I. (1988). Top Management Group Heterogeneity and Firm Performance Strategic Managenent Jourmal, 10, 125-141.

Mutsaerts, G. (1992). 1991: Het jaar van de grote herorièntatie. Adformatie, 8, Febnuary 20, $6-13$.

Nachum, L. (1993). Winners and Losers in Professional Service Industries: What Makes the Difference? A Case Study of the Advertising Industry. Paper presented at the EISAM Workshop on Global Strategies in the Sevice Industries, Brussels, september.

Nieman, H.J. (1989). Het Reclame-adviesbureau. In: Handboek reclame. Deventer: Kluwer, Chapter $5.4 .2,1-8$.

Norburn, D, and Birley, S. (1988). The Top Management Team and Corporate Performance Sirategic Managenent Jonmal, 9, 225-237 
Oswald, S.L. and Jahera, JS. Jr. (1991). The Influence of Ownership on Performance: An Empirical Study. Strategic Mandgement Journd, 12,321-326.

Pakes, A and Ericson, R. (1989). Empincal Implications of Alremaive Models of flm Dymamics. Working Paper no. 2893 Cambridge, Mass.: NBER

Pennings, J.M., Lee, K and Witteloostuijn, van A. (1997). Population Ecology and Firm Resources: A Study of Professional Service Firms

Pfeffer J. (1983). Organizational Demography. In: L. L. Cummings and B.M Staws (eds), Research in Organizational Behawior, 5, 299-357. Greenwich CT: JAI Press.

Pfeffer, J. and $\mathrm{O}^{\prime}$ Reilly, C. (1987). Hospital Demography and Turnover among Nurses. Industrial Relations, 36, 158-173.

Pfeffer, J. and Salancik, G.R. (1978). The Externa Combol of Organzations: A Resownte Dependence View. New York: Harper and Row.

Porter, M. (1980). Competitive Strategy: Techniques for Analyzing Industries and Compentlor: New York: Free Press.

Preisendörfer, P, and Voss, T. (1990). Organizational Mortality of Small Firms: The Effects of Entrepreneurial Age and Human Capital. Organization Studies, 11, $107-129$.

Ramanujam, V. and Varadarajan, P. (1989). Research on Corporate Diversification: A Synthesis. Strategic Management Jommal, 10, 523-551

Rumelt, R.P. (1974). Strategy, Smachre and Economic Perfomance. Cambridge, MA. Harvard University Press.

Rumelt, R.P. (1982). Diversification Strategy and Profitability. Sfrategic Management Journal, 3, 359-369.

Schmalensee, R, and R.D. Willig (eds) (1989). Handbook of Mdustrial Organizarion. Amsterdam: North-Holland.

Shaw, ME. (1981). Group Dynamics: The Psychology of Small Group Beharion. Ird ed. New York: McGraw-Hill.

Scherer, F.M. and Ross, D. (1990). Industrial Market Sinchure and Economic Performance. Boston: Houghton Mifflin.

Schreuder, H. (1993). Timely Management Changes as an Element of Organizational Strategy. Journal of Management Studies, 30, 723-738.

Schreurs, W. (1989). Geschiedenis van de Reclame in Nederland, 1870 -1990. Utrech: Het Spectrum.

Siegfried, JI. and Evans, L.B. (1994). Empirical Studies of Entry and Exit: A Survey of the Evidence Review of Industrial Organizarion, $9,121-155$.

Singh, J., House, R.J. and Tucker, D.J. (1986). Organizational Change and Organizational Mortality. Administrative Science Qnaterly, 31, 587-611

Sleuwaegen, L. And Dehandschutter, W. (1991). In: Geroski, P. and Schwalbach, J (ads), Eniry and Market Contestability. An international Comparison, Oxford: Basil Blackwell.

Smith, J.E., Carson, K. P and Alexander, R.A (1984). Leadership: It Can Make a Difference. Academy of Manowgement Jownal, 27, 765-776.

Smith, K.G., Smith, K.A., Olian, J D., Sims, H.P Jr, O'Bannon, D.P. and Scully, J.A. (1994). Top Management Team Demography and Process: The Rolle of Social Integration and Communication. Administraive Science Quarferly, 39, 412-438.

Sutton, J. (1991). Sunk Costs and Market Strwcture. Cambridge, MA: MIT Press.

Taylor, R.N. (1975). Age and Experience as Determinants of Managerial Information Processing and Decision Making Performance. Academy of Manogement Jonrhal, 18, 7481. 
Thomas, A B. (1988). Does Leadership Make a Difference to Organizational Performance? Adminsirative Science Quarterly, 33, 388-400.

Thurik, A.R. and Audretsch, D.B. (1996). The Dynamics of Industrial Organization, Review of Indistial Orgamization, 11. 149-153.

Tirole, J. (1988). The Theory of Industrial Organization. Cambridge, Mass: MIT Press.

Troske, K. (1993). The Dynamic Adjustment Process of Firm Entry and Exit in Manufacturing, and Finance, Insurance, and Real Estate. US Census Bureau, Working Paper. Forthcoming in the Jounal of Law and Economics.

Vancil, R. $\mathrm{F}$. (1987). Passing the Baton: Managing the Process of CEO Succession. Boston: Harvard Business School Press.

Verbeke, W. (1989). Developing an Advertising Agency-Client Relationship in the Netherlands. Joumal of Advertising Research, December 1988/January 1989, 19-27.

Wagner, J. (1994). The Post-Entry Performance of New Small Firms in German Manufacturing Industries. The Jownal of Industrial Economics, 2, 141-154.

Wagner, W.G., Pfeffer, I. And O'Reilly, C.A. (1984). Organizational Demography and Turnover in Top Management Groups. Administrative Science Quarterly, 29, 74-92.

Wanous, J.P. (1980). Organizational Entry, Recrutment, Selection, and Socialization of Newcomers. Reading MA Addison-Wesley.

Weiner, $N$, and Mahoney, T.A. (1981). A Model of Corporate Performance as a Function of Environmental, Organizational and Leadership Influences. Academy of Management Joumal, $24,453-470$.

Weitzel, W. and Johnsson, E. (1989). Decline in Organizations: A Literature Integration and Extension. Administrative Science Quarterly, 34, 91-109.

Wiersema, M.F. and Bantel, K.A. (1992). Top Management Team Demography and Corporate Strategic Change. Academy of Management Journal, 35, 91-121.

Winter, S.G. (1964). Economic 'Natural Selection' and the Theory of the Firm. Yale Economic Esscys, 4, 225-272

Witteloostuijn, van A. (1996). Bridging Behavioral and Economic Theories of Decline Organizational Inertia, Strategic Competition and Chronic Failure. Forthcoming in Management Science.

Witteloostuijn, van A, Boone, C.A.J.J., Iterson, A.Th.M. Olie, R.L. and Van Well, R. (1997). Van Courantier lot Strateeg. De Rol wan Krant en Management in het Nederlandse Krante( $m$ )bedriff 1950-1995. Den Haag: Otto Cramwinckel. 


\section{ORGANISATIEVERANDERING, MANAGEMENTKAPITAAL EN BEDRIJFSPRESTATIES}

\section{Een empirische analyse van bedrijfssucces in de Nederlandse bedrijfstak van reclame-adviesbureaus, in de periode $1984-1994$}

Waarom is de ene onderneming succesvol terwijl de andere faalt? Dit is een centrale vraag in de organisatiewetenschappen en onderwerp van het huidige proefschrift. Het doel van dit onderzoek is het bestuderen van een geintegreerde verzameling van factoren in relatie tot individuele bedrijfsprestaties, op drie niveau's van analyse: de bedrijfstak, de organisatie en het topmanagementteam. De analyse van de bedrijfstak, het hoogste niveau van analyse, is beschrijvend van aard en betreft aspecten van de marktstructuur en de marktdynamiek. De twee lagere niveau's van analyse worden behandeld via studies naar de directe effecten van respectievelijk organisatieveranderingen en topmanagementteamkenmerken op bedrijfsprestaties. Belangrijk hierbij is dat in de twee studies zowel twee financiële prestatiematen, met name omzet en groei, als de kans op overleven worden onderzocht. Om met betrekking tot het effect van organisatieveranderingen het belang van bedrijfsomvang te belichten, zijn de analyses bovendien apart uitgevoerd onder kleine en grote ondernemingen. Het onderzoek is verticht in de Nederlandse bedrijfstak van reclame-adviesbureaus, in de periode 1984 - 1994.

Hoofdstuk 1 plaatst de verschillende onderzoeken in een raamwerk. Er wordt aangegeven welke effecten er precies worden onderzocht en in welke theorieèn de studies zijn ingebed. Hoofdstuk 2 beschrijft de contouren van het databestand en de methode van gegevensverzameling. Tevens worden enkele aspecten van de marktstructuur belicht, te weten de concentratiegraad en de top-tien van de Nederlandse reclamebureaus. Het totale databestand bestaat uit 318 reclame-adviesbureaus over maximal elf jaar, uitmondend in 2321 observaties. Hiermee is het belangrijkste deel van het segment van grotere reclamebureaus (met minimaal drie personeelsleden) gedekt. De bedrijven die deel uitmaken van het databestand, nemen zo'n 70 procent van de totale reclame-uitgaven in Nederland voor hun rekening. Echter, als gevolg wan sterke variatie in de beschikbaarheid van de benodigde bedrijfsgegevens verschilt de onvang van de steekproef per studie. Voor het onderzoek is gebnik gemaakt wan secundaire data, afkomstig uit, onder andere, reclamejaarboeken (Adformatie Bijlage en de Blauwe Burogids) en van regionale Kamers van Koophandel.

Analyse van de marktstructuur toont aan dat de Nederlandse bedrijfstak wan reclameadviesbureaus, in de periode 1984-1994, wordt gekenmerkt door een gematigde concentratiegraad. Terwijl in deze jaren het marktadndeel van de vier grootste individuele reclamebureaus varieert tussen de 11 en 13 procent, nemen de vier grootste bureaugroepen gemiddeld 20 procent van de totale omzet voor hun rekening. Zowel de top-tien van de individuele bureaus 
als die van de bureaugroepen blift opmerkelik stabiel tussen 1984 en 1994. Terwjl het bijzonder moelink is om de bureaugroep top-tien binnen te dringen, is het enkele individuele bureaus gelukt exn plaats te veroveren in de top-tien van individuele bureaus.

In het eerste deel van Hoofdstuk 3 wordt de dynamiek van de reclame-adviesmarkt in termen van toe- en uittreding beschreven. Het tweede deel van Hoofdstuk 3 betreft een analyse van de prestathes van nieuwkomers gedurende de jaren volgend op het moment van toetreding en van falers in de jaren voorafgaand aan uittreding. De resultaten tonen aan dat de Nederlandse reclame-adviesmarkt een vrij dymamische bedrijfstak is met, in de periode $1984-1994$, gemiddelde toe- en uittredingspercentages van respectievelijk 7,33 en 4,35 procent. Bedrijven die de markt verlaten, zijn enigszins groter dan de organisaties die nieuw toetreden. Met name de bureaus die nittreden ten gevolge van een fusie, zijn gemiddeld vrij groot. Hun omvang overstijgt zelfs die van het gemiddelde overlevende bureau. De meeste nieuwkomers zijn kleine zelfstandige ondernemingen die in de jaren volgend op toetreding wrij goed presteren. Negen jaar later hebben zij veelal de gemiddelde ornwang van eerder gevestigde ondernemingen bereikt, terwijl slechts een vrij kliein percentage de markt in de eerste jaren na toetreding weer verlaat. Veel falende reclamebureaus zijn, evenals de nieuwkomers, klein en geheel eigendom van de directie. Uittreding wordt over het algemeen voorafgegan door lage productiviteitsniveau's en sterk wisselende maten van groet. Reclamebureaus die uittreden via een fusie of overname vertonen relatief goede bedrijfsresultaten in de jaren voorafgaand aan deze gebeurtenis, ook in vergelijking met overlevende organisaties. De goede prestaties maakten deze bureaus aantrekkelijke kandidaten voor fusie of overname.

In Hoofdstuk 4 staat de relatie tussen organisatieveranderingen en bedrijfsresultaten centraal. Dit onderzoek is gebaseerd op de voluntaristische versus deterministische benaderingen. Aanhangers van het eerste perspectief menen dat stralegische veranderingen noodzakelijk zijn om te overleven, terwijl voorstanders van de tweede opvatting argumenteren dat inertie een vereste is om to overleven. Het effect van veranderingen in strategie, structur en topmanagementteamcompositie op de eerder genoemde drie prestatiematen wordt apart onderzocht voor kleine en grote reclamebureaus. Geen van beide visies wordt met de resultaten unaniem bevestigd. De uitkomsten tonen aan dat de richting en kracht van de effecten sterk afhankelijk zijn van de soort verandering, de prestatiemaat en de bureauomvang. De prestaties van kleine reclamebureaus worden sterker beinvloed door onganisatieveranderingen dan die van grote bureaus. Voor kleine reclaneondernemingen bliken mutaties in het topmanagementteam en naamsveranderingen een positief effect te hebben op financiële prestaties, terwijl verhuizing naar een andere stad en toenamen in media dienstendiversificatie een teruggang in financiële bedrijfiresultaten tot gevolg hebben. Grote bureaus ondervinden nadelige financiële effecten van naarusveranderingen. Geen van de onderzochte veranderingen in bedrifsfactoren heeft een significante uitwerking op de overlevingskansen wan de reclamebureaus. 
Hoofdstuk 5 betreft de relatie tussen de samenstelling van het topmanagementteum en bureauprestaties. Dit onderzoek berust op de gedachte dat bedrifsstrategicen en prestaries medebepaald worden door de eigenschappen van de managers. Aanhangers van dit standpunt argumenteren dat demografische kemmerken wan mensen, zoals hun leefiji, ambistermijn en opleiding verwijzen naar onderliggende watarden en attitudes die in belangrijke mate strategi* sche keuzes en daarmee bedrijfsprestaties beinvloeden. In het huidige proefschrift wordt het effect onderzocht op de drie prestatiematen van het top management teans" gemiddelde en spreiding in leeftijd en bureauambtstermijn (het aantal jaar dat een directielid in een bepaald bureau werkzaam is) alsmede het percentage directieleden met bedrifstakerwaring en aandelen in het bureau. De bevindingen tonen een concave relatie aan van de gemiddelde bureauanbustermijn van de topmanagers met beide financièle prestatiemaatstaven. De bureau-omzet bereikt haar top wanneer de directieleden gemiddeld 9,7 jaar in het bureau werkzaam zijn, terwill de bedriffsgroei het hoogst blijkt te zijn bij een gemiddelde bureaumatstermijn van 8,8 jaar. De omzet van bureaus met wee of meer directieleden neemt toe naarmate de spreiding in de leeftijd onder de teamleden stijgt en de diversiteit in de managers" bureauambtsteminen afineent. De groei van deze grotere bureaus wordt vervolgens beinvloed door een interactie in de gemiddelde en spreiding in de bureauambtstermijnen van de managers. De uitkomsten geven aan dat wameer de gemiddelde bedrijfsperiode korter dan 12 jaar is, homogeniteit in deze eigenschap groei bevordert, terwijl wanneer de gemiddelde bureautermijn langer is dan 12 jaar, spreiding in dit kenmerk de groei positief beinvloedt. De bevindingen doen tenslotte vermoeden dat in de jaren dat bureaus slecht presteren managers die geen vroegere ervaring bij een top bureau hebben en geen aandelen in het bureau bezitten als eerste gedwongen dan wel vrijwillig hun bureau verlaten.

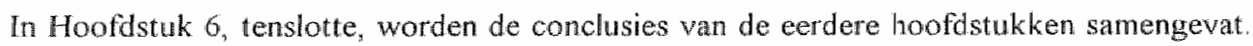
Eerst worden de empirische bevindingen geresumeerd voor ieder van de onderzochte effecten. Vervolgens wordt ingegaan op het verband tussen de drie prestatiemaatstaven en de gebruikte methoden van analyse. Nadat de belangrijkste conclusies zijn herhaald, word hel proefschrift afgesloten met suggesties voor toekomstig onderzoek. 


\section{Curriculum Vitae}

Ciska M. Bosman was born on August 26, 1967 in Utrecht. After highschool she studied French culture for one year at the Sorbonne in Paris. From 1987-1992 she studied Psychology at the Unversity of Amsterdam. In 1988 she followed a semester of psychology at the University of Nice, France, and in 1992 she completed an internship at a market research agency in Antibes, France. In January 1993 she joined the department of Organization Studies at the faculty of Economics and Business Administration of the University of Maastricht to write her dissertation. Since January 1997 she is part of the same department, now as an assistant professor

Ciska M. Bosman is geboren op 26 augustus 1967 te Utrecht. In 1986 slaagde zij voor haar eindexamen VWO waarna zij een jaar Franse cultuur heeft gestudeerd aan de Sorbonne te Parijs. Van 1987-1992 studeerde ze psychologie aan de Universiteit van Amsterdam. In 1988 heeft zij een trimester psychologie gevolgd aan de universiteit van Nice, Frankrijk, en in 1992 heeft ze een stage gedaan bij een marktonderzoekbureau in Antibes, Frankrijk Van januari 1993 tot en met januari 1997 was zij als assistent-in-opleiding verbonder aan de sectie Organisatie van de Universiteit Maastricht. Sinds januari 1997 is zij bij dezelfde sectie in dienst als universitair docent. 